Alexandre Torres Porres

\title{
Modelos Psicoacústicos de Dissonância para Eletrônica ao Vivo
}




\section{Alexandre Torres Porres}

\section{Modelos Psicoacústicos de Dissonância para Eletrônica ao Vivo}

Tese apresentada ao Programa de Pós-Graduação em Música, área de concentração - Musicologia. Linha de Pesquisa - História, Estilo e Recepção, da Escola de Comunicações e Artes da Universidade de São Paulo, como exigência parcial para obtenção do Título de Doutor em Artes, sob a orientação do Prof. Dr. Marcelo Queiroz e co-orientação do Prof. Dr. Fernando Iazzetta.

São Paulo, 2012 
Porres, Alexandre Torres

Modelos Psicoacústicos de Dissonância para Eletrônica ao Vivo.

Tese - Doutorado - Pós-Graduação em Música.

Universidade de São Paulo.

Eletrônica ao vivo - Pure Data - Modelos Psicoacústicos Curvas de Dissonância. 
ALEXANDRE TORRES PORRES

MODELOS PSICOACÚSTICOS DE DISSONÂNCIA PARA ELETRÔNICA AO VIVO

COMISSÃO JULGADORA

TESE PARA OBTENÇÃO DE GRAU DE DOUTOR

Presidente e orientador Porf. Dr. Marcelo Queiroz (USP)

2. ${ }^{\circ}$ Examinador $\quad$ Prof. Dr. Sérgio Freire (UFMG)

3. ${ }^{\circ}$ Examinador $\quad$ Prof. Dr. Jônatas Manzolii (UNICAMP)

4. ${ }^{\circ}$ Examinador Prof. Dr. Régis Faria (USP)

5. ${ }^{\circ}$ Examinador Prof. Dr. Fábio Kon (USP)

São Paulo, 14 de Fevereiro de 2012. 
Aos meus avós.

Junilde Maron Torres Hélcio de Andrade Torres
27.03.1928 / 07.08.2011

03.02 .1928 / 25.12.2011 


\section{Agradecimentos}

Não se faz um doutorado sozinho! A sós temos apenas uma idéia, uma vontade, uma busca, e é somente com uma rede de amigos e profissionais que isso cresce e se concretiza. Os apoios ocorrem de várias maneiras e, em muitas vezes, em mais de uma única forma. Mas posso resumir em dois pilares: um de apoio e colaboração profissional, outro simplesmente moral, de profunda amizade e companheirismo. Sem o primeiro pilar, nada seria possível, mas, sem o segundo, não seria um processo igualmente agradável e, de alguma forma, também impossibilitaria essa jornada maluca que escolhemos.

Sinto que este texto é a "Parte II" do meu mestrado. E assim, faço um convite para que busquem lá um complemento e germe inicial desta pesquisa. Na dissertação de mestrado fiz questão de agradecer e dar conta de todos que fizeram parte da minha vida musical e acadêmica até então. Portanto, reforço o papel dessas pessoas, sem as quais também não chegaria aqui.

Logo no início dessa nova fase, Juliana França foi uma ótima companheira em horas conturbadas e decisivas de empreitadas malucas, saudades.

Foi um prazer ter a chance e privilégio de fazer parte do grupo de pesquisa MOBILE na USP, a todos os membros, diretores e colaboradores, obrigado.

Velhos companheiros de outros carnavais continuam aí, agora colegas da USP e do grupo de pesquisa, como Henrique Iwao, Mário Del Nunzio, Alexandre Fenerich, Giuliano Obici, Lílian Campesato. Em especial ao amigo Fenerich, que sempre me alertava de prazos e outras informações e toques imprescindíveis até o momento do depósito deste texto, além de umas considerações mais que bemvindas.

Novos amigos e colegas me ajudaram a viabilizar a idéia de realizar uma convenção de Pure Data no Brasil nesse período, que teve um impacto muito feliz e positivo na minha carreira. Obrigado especial ao Ricardo Palmieri e Paloma Oliveira na formação da cúpula. Lina Lopes e Iwao pela força na hora da verdade. E muito obrigado aos que apoiaram esse projeto: Sérgio Basbaum, Marcelo Bressanin e Cássio Quitério.

Agradecimentos diversos para toda a comunidade mundial de $\mathrm{Pd}$, amigos e desconhecidos que sempre oferecem ajuda ou feedback para diversas questões via internet. Conheci diversos artistas e pesquisadores de trabalhos inovadores e inspiradores nas convenções de Pd e fiz diversos amigos, em especial: Nick Porcaro, Alexandre Castonguay, Mathieu Bouchard, William Brent, Teresa Ascenção, Hans Christoph-Steiner e Miller Puckette.

Agradeço aos parceiros de empreitadas musicais que me ajudaram a botar idéias da pesquisa em prática, como o velho grupo EntreCompositores, pela jornada de produzir a $\mathrm{I}^{\mathrm{a}}$ Bienal Música Hoje em Curitiba com nosso concerto de encerramento nessa nova encarnação (Márcio, Orlando, Fernando, Vinícius, Lucas e Franco in memoriam). Maurício Dottori pela ótima vontade em me ajudar com a peça e as aulas de orquestração que nunca tive. Marcel Steuernagel pelo ótimo trabalho na regência. O incrível grupo Platypus pelo apoio além do necessário, em especial as competentíssimas solistas Sieglinde Größinger e Theresia 
Schmidinger. E, por fim, um agradecimento especial para Rogério Costa que esteve ali quando possível para testar meus protótipos em nosso duo.

André Salim Pires pela colaboração e primeira ajuda com implementação em objetos. Mathieu Bouchard por verdadeiras aulas de programação no estágio na Canadá. E ao colega de USP Flavio Luiz Schiavoni por prometer não me deixar órfão nesse quesito daqui a pouco.

Um agradecimento mais do que especial a Sean Ferguson pela orientação no CIRMMT/McGill - e por fazer a inscrição no estágio acontecer indo atrás de mim para perguntar se eu precisava de algo mesmo quando seu email deu pau e me filtrou no spam! A Marcelo Wanderley por me acolher no Music Tech Building, mesmo quando eu quase botei fogo no laboratório. Novamente a Alexandre Castonguay pelo acolhimento em terras estrangeiras montrealenses. Júlio Costa pela grande amizade e companheirismo que selamos lá.

Bruno Giordano pela ajuda no design do teste, Danilo Ramos pela ajuda na análise estatística. Clarence Barlow, pelo apoio de sempre, pelo compartilhamento de seus códigos e prontidão a atender diversas dúvidas.

Ao sr. Guilherme Rebbechi, por sua excentricidade e amizade pra qualquer hora mesmo distante, mas também por se oferecer a fazer uma revisão cuidadosa de uma parte deste texto. À Natacha Mauer e Missionário José que ouviram gritos de socorro e ajudaram em revisões emergenciais do texto. Quel pela companhia no karaokê e a zelosa e antropôrtima revisão profissional. Caio por me encher o saco que eu lançasse logo o [Brane ] (ou pra não ficar de fora).

Só que mais importante, este texto não existiria sem Marcelo Queiroz e Fernando Iazzetta, pela orientação deles e por apostarem no meu trabalho, me dando essa chance de desenvolver esta pesquisa!

Não posso deixar de agradecer ao simples fato do Primus ter voltado à ativa e do Faith No More ter ressurgido do nada para dar uma alegria na minha vida chamando ainda Trey Spruance para tocar o disco King For a Day Fool For a Lifetime na íntegra. E agradecer o próprio Trey por apostar no meu trabalho de produção e vir para o Brasil com seus Chefes Secretos (Timba, Ches, Toby e Matt).

Yoga Studio é uma escola de Yoga que fica em Curitiba mas é a melhor escola de Yoga do mundo.

A meus queridos avós por terem ficado tanto tempo conosco, nesses mais de 60 anos de vida feliz e amorosa que tiveram juntos. A meu avô por ser um modelo de vida. À minha vó por todo o apoio, orgulho e vínculo musical que tivemos. Hélcio de Andrade Torres e Junilde Maron Torres, descansem em paz! 


\section{RESUMO}

O principal problema desta tese é a aplicação da teoria psicoacústica sobre percepção de dissonância em novas ferramentas de computação musical em tempo real. Os objetivos e contribuições incluem: Prover uma revisão critica do Estado da Arte em teoria psicoacústica de modelos de dissonância, projetar trabalhos futuros; Explorar um potencial criativo negligenciado de modelos psicoacústicos de dissonância em Eletrônica ao Vivo; Desenvolver novas ferramentas computacionais baseadas na teoria; Investigar o potencial e limitações da teoria e técnicas. Discutir sua pertinência e impacto; Tornar a teoria e técnicas mais acessíveis a músicos por meio deste texto e as ferramentas desenvolvidas.

A percepção de Dissonância é um fenômeno complexo em que a abordagem psicoacústica cobre apenas uma porção. Além disso, ainda há muito debate na área da psicoacústica sobre o desenvolvimento de modelos de dissonância. Portanto, a tese apresenta uma revisão crítica do Estado da Arte da teoria psicoacústica, apontando pontos fracos e fortes do atual conhecimento, e futuros desenvolvimentos no campo. Um teste perceptivo também foi elaborado para gerar ponderações relevantes.

Os modelos foram implementados em Pure Data, e uma série de patches foi desenvolvida para testar o potencial criativo em eletrônica ao vivo. Esse processo culminou em um sistema desenvolvido em Pure Data que agrega diversas das técnicas baseadas nos modelos psicoacústicos. Suas possibilidades incluem, por exemplo, encontrar intervalos consonantes de acordo com um espectro, ou alterar componentes espectrais para que estejam de acordo com uma escala musical ou afinação particular.

Essas ferramentas foram empregadas em um duo de improvisação livre com o autor e um saxofonista. O autor também compôs uma peça orquestral que utilizou o sistema desenvolvido na parte de eletrônica ao vivo. 


\begin{abstract}
The problem of this research is to apply the state of the art in psychoacoustic theories about dissonance perception in the development of novel creative computer music tools for composition and live electronics. Goals and contributions include: To provide a critical review of the State of the Art in Psychoacoustic theory regarding dissonance modeling, project further work; To explore neglected creative potential of psychoacoustic dissonance models in Live Electronics; To develop novel computer music tools based on the theory; To investigate the potential and limitations of the theory and techniques; To discuss its creative musical impact and pertinence; To make the theory and techniques more accessible to musicians through the text and the free developed tools.

The perception of Dissonance is a complex phenomenon in which the psychoacoustical approach covers just a portion thereof. Not only that, but psychoacoustic theory is still in debate about the development of dissonance models. Therefore, the thesis provides a critical review of the state of the art in psychoacoustic theory, pointing out weaknesses and strong points of the current knowledge, and future developments in the field. A perceptual test was also designed to generate data for relevant insights.

Apart from the theoretical review, the models were implemented in Pure Data, and a series of patches was developed in order to test their creative potential in Live Electronics. This culminated in a system developed as a Pure Data Patch that aggregates several techniques based on the psychoacoustic models. Their possibilities include, for example, finding consonant intervals according to a spectrum, or altering spectral components so they are in accordance to musical intervals and particular tunings. These tools were used in a Free Improvisation duo with the author and a sax player, and the author also composed an orchestral piece that applied the developed system in the Live Electronics section.
\end{abstract}




\section{SUMÁRIO}

Introdução:

Parte I - Revisão Teórica da Base Sensorial da Dissonância Musical

Introdução:

1) A Psicoacústica como uma Base Sensorial da Percepção Musical

1.1 - Psicoacústica

1.2 - Diferentes Níveis de Percepção

1.3 - Diferentes Níveis em Psicoacústica e Descritores de Áudio

2) Conceitos de Dissonância e Relação com Atributos Perceptivos

3) Base Sensorial da Dissonância Musical em Psicoacústica e Seus Atributos

3.1 - Dissonância Sensorial

3.1.1 Dissonância Sensorial versus Dissonância Musical

3.1.2 Dissonância Sensorial versus Sensory Pleasantness

3.2 - Quadro de Atributos de Ernst Terhardt

4) Descrição dos Atributos Psicoacústicos

4.1 - Grupo de Dissonância Sensorial $\quad 22$

4.1.1 Brilho 22

4.1.2 Aspereza 23

4.1.3 Tonalness (Clareza de Percepção de Altura) 27

$\begin{array}{ll}\text { 4.1.3.1 Altura Virtual (Virtual Pitch) } & 28 \\ 4.2 \text { - Grupo de Harmonia } & 33\end{array}$

4.2.1 Fundamental do Acorde $\quad 34$

4.2.2 Afinidade de Tons: Comonalidade de Altura 36

4.3 - Considerações Finais e outros Atributos $\quad 37$

4.3.1 Fusão Tonal 39

5) Modelos Psicoacústicos $\quad 42$

5.1 - Modelo de Brilho 43

5.2 - Modelo de Aspereza $\quad 45$

5.3 - Modelo de Altura Virtual e Tonalness $\quad 51$

5.3.1 Primeiro Estágio: Peso de Alturas Espectrais $\quad 52$

5.3.2 Segundo Estágio: Modelo de Altura Virtual 53

5.3.3 Terceiro Estágio; Modelo de Tonalness 54

5.4 - Modelo de Altura Virtual aplicado aos Atributos de Harmonia $\quad 55$

5.4.1 Descrição Final do Modelo de Comonalidade de Altura 56

5.5 - Outros Modelos Relacionados à Harmonia $\quad 58$

$\begin{array}{ll}\text { 5.5.1 Harmonicidade } & 58\end{array}$

$\begin{array}{ll}\text { 5.5.2 Entropia Harmônica } & 60 \\ \text { 6) Considerações Finais } & 62\end{array}$

Parte II - Desenvolvimento de Ferramentas Criativas
Introdução:

7) Estado da Arte de Aplicações Criativas $\quad 68$

7.1 - Aplicação em Afinação e Escalas Musicais $\quad 69$

7.2 - Exemplos de trabalhos em Composição Assistida por Computador $\quad 70$

$\begin{array}{ll}\text { 7.2.1 Sistema Apprentice, de Sean Ferguson } & 71\end{array}$

7.2.2 Sistema AUTOBUSK \& Dissonometer, de Clarence Barlow $\quad 74$

7.3 - Aplicações com Descritores de Áudio $\quad 77$

$\begin{array}{ll}\text { 7.3.1 Identificação de Alturas } & 79\end{array}$

7.3.1.1 Acompanhamento de Partitura (Score Following) $\quad 80$

7.3.1.2 Antescofo (Expansão do Paradigma) 81

7.3.1.3 Outras Aplicações com Detecção de Alturas $\quad 81$

7.3.2 Identificação de Timbres e Reconstrução de Timbres $\quad 82$

7.3.3 Expansão com "Descritores de Dissonância" 84

8) Extração de Componentes Espectrais 86

8.1 - Análise Espectral (Características e Implicações) 86 
8.2 - Extração de Listas de Parciais com [sigmund ] 90

9) Objetos Desenvolvidos

9.1 - Objeto [sharpness] 92

9.2 - Biblioteca do Modelo de Aspereza $\quad 92$

9.2.1 Conversor de dB para Phons e Sones $\quad 92$

9.2.2 Conversão de Hz para a Escala da Banda Crítica (Barks) 97

$\begin{array}{ll}\text { 9.2.3 Objeto [roughness] } & 98\end{array}$

9.2.3.1 - Performance do Objeto [roughness] 100

9.3 - Biblioteca de "Pitch Commonality" 102

9.3.1 Implementação do Código de Parncutt em Patch de Pure Data 103

9.3.2 Objeto [tonalness] 106

9.3.3 Objeto [Pitch_Weigth] 107

9.3.4 Objeto [Pitch_Salience] 109

9.3.5 Objeto [Pitch-Commonality] 110

9.3.5.1 Comparação Avançada 112

9.4 - Harmonicidade $\quad 115$

10) Patches Desenvolvidos 118

10.1 - Separação de Ruído de Fundo e Qualidade Tonal 118

10.2 - Ressíntese via Banco de Osciladores $\quad 120$

10.3 - Mudança de Altura (Pitch Shifting) 122

10.3.1 Picth Shiftting via Ressíntese $\quad 123$

10.3.2 Phase Vocoder 123

10.3.3 Harmonizador em Tempo Real 129

10.4 - Manipulação Espectral $\quad 130$

10.4.1 Síntese Cruzada (Vocoder) 130

10.4.2 Modulação de Amplitude 132

10.4.2.1 Modulação Complexa 134

10.4.3 Controle Arbitrário de Parciais via Ressíntese 136

10.4.3.1 Mapeamento Espectral 138

10.5 - Curvas de Dissonância e Geração de Escalas a partir de Sonoridades 141

10.6 - Autotuner e Gerador de Escalas 148

11) [Brane ]: Um Sistema para Interação em Tempo Real Desenvolvido em Pure Data 151

11.1 - Resumo do Sistema $\quad 152$

11.2 - Base do Sistema $\quad 153$

11.3 - Capacidades Avançadas $\quad 156$

11.4 - Outras Considerações $\quad 158$

12) Considerações Finais 160

12.1 - Contribuições em Relação ao Trabalho de Sethares 160

12.2 - Design e Acessibilidade 163

12.3 - Outras Considerações 165

Parte III - Discussão Final

$\begin{array}{ll}\text { Introdução: } & 167 \\ 13) \text { Discussân } & 168\end{array}$

13) Discussão Teórica Crítica 168

13.1 - Recapitulação da Teoria Psicoacústica 168

13.2 - Discussão Teórica sobre a Modelagem de Dissonância 170

13.2.1 Curvas de Dissonância em Duas Dimensões Principais 172

13.2.2 Revisão dos Modelos de Aspereza 173

13.2.3 Aspereza versus Harmonicidade 178

13.3 - Teste perceptivo de Dissonância sob uma Perspectiva Sensorial $\quad 181$

$\begin{array}{ll}\text { 13.3.1 Estímulos } & 182\end{array}$

13.3.2 Teste e Resultados 184

13.4 - Considerações Finais 189

14) Discussão Final Sobre Aplicações Criativas 192

14.1 - Exemplos Criativos 192

14.1.1 Duo de improvisação Livre com Rogério Costa 192 


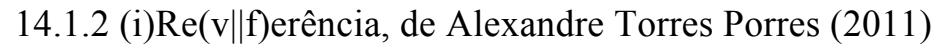

14.2 - Impacto de Modelos Psicoacústicos de Dissonância em Criação Musical

14.2.2 Teoria Psicoacústica e Teoria Musical, um Anacronismo

14.3 - Por uma Abordagem Voltada ao Concreto

15) Conclusão

15.1 - Teoria Psicoacústica

15.2 - Impacto e Contribuição Criativa

15.3 - Projeções Futuras

206

Referências

Anexo I - Partitura de (i) Re(v||f)erência

Anexo II - CD-ROM 


\section{Introdução:}

O ponto central e originário dos problemas desta pesquisa está no processo de percepção sonora e na investigação de como conseguimos identificar e perceber certos atributos sonoros.

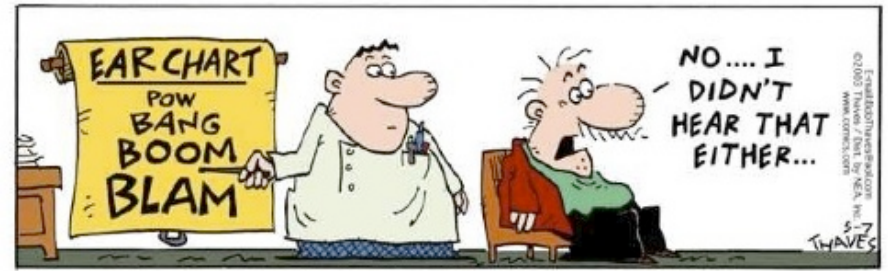

"Não... também não escutei isso".

(Frank \& Ernest by Thaves)

O presente trabalho visou uma aplicação criativa do estado da arte em modelos psicoacústicos de dissonância em novas ferramentas de eletrônica ao vivo (Live Electronics) para composição e improvisação. Apesar do fim criativo, os problemas encontrados durante a pesquisa envolvem três diferentes searas: Psicologia da Música, Computação Musical e Composição/Improvisação. Por esse perfil interdisciplinar, este trabalho se caracteriza como um estudo na área de Sonologia, como definida por Iazzetta (2008).

A percepção de Dissonância é um fenômeno complexo, onde a abordagem psicoacústica cobre apenas uma porção. Além disso, o problema de quais seriam os atributos psicoacústicos da dissonância e como eles contribuiriam para uma percepção geral de dissonância ainda é uma questão aberta e em pleno debate e investigação.

A referência teórica principal nesta pesquisa é a de Ernst Terhardt (1984), que expõe dois grupos de atributos perceptivos relacionados à percepção de dissonância: Dissonância Sensorial e Harmonia. Os conceitos de todos os atributos de cada grupo, sua história, desenvolvimento e modelos existentes foram investigados para nos dar uma base para sua implementação em ferramentas criativas. Alguns elementos paralelos também foram investigados e colocados em perspectiva.

Uma revisão teórica crítica levanta pontos fracos $\mathrm{e}$ fortes do atual conhecimento, apontando para futuros desenvolvimentos nesse campo. Nela, apresentamos algumas discrepâncias encontradas entre diferentes modelos e debatemos qual resultado seria o mais acurado e as implicações dessas considerações. 
Também debatemos sobre como diferentes atributos contribuem para a percepção de dissonância e um teste psicoacústico foi desenvolvido para nos ajudar a levantar pontos relevantes.

Como o principal objetivo está na aplicação criativa da teoria psicoacústica, a revisão teórica tange a questão do impacto e relevância da adoção desses modelos psicoacústicos no desenvolvimento de ferramentas criativas, que serviram de laboratório de testes para a elaboração de algumas das conclusões apresentadas.

Os modelos estudados foram implementados em Pure Data ${ }^{1}$ em uma biblioteca de objetos. Uma série de patches $^{2}$ foi desenvolvida para testar o potencial criativo desses modelos em eletrônica ao vivo.

Os patches culminaram no desenvolvimento de [Brane $]$ - um sistema que agrega a maior parte das técnicas apresentadas. Essas incluem, por exemplo, encontrar intervalos musicais consonantes de acordo com um espectro sonoro, ou alterar componentes espectrais para que fiquem de acordo com uma Escala/Sistema de Afinação. Essas ferramentas foram adotadas pelo autor em um duo de improvisação livre e na parte de eletrônica ao vivo em uma peça orquestral.

Seguindo com o objetivo principal de pesquisa, o desenvolvimento de patches e objetos apresentam novas ferramentas criativas em tempo real. Com eles, um potencial negligenciado foi explorado. Esses frutos da pesquisa estão acessíveis e disponíveis por meio desta tese, e os próprios objetos e patches, que são distribuídos como códigos livres.

A tese divide-se em três partes. A primeira expõe a teoria psicoacústica e uma discussão inicial sobre a Base Sensorial da Dissonância Musical com seus atributos e modelos desenvolvidos. A segunda parte traz as ferramentas criadas durante a pesquisa a partir da implementação dos modelos. A terceira e última parte traz uma revisão teórica crítica e uma discussão final sobre a aplicação criativa da teoria psicoacústica.

\footnotetext{
1 Pure Data, ou apenas Pd, é um ambiente de programação gráfica originalmente criado para desenvolver aplicativos de computação musical em tempo real. Mais informações em $<\mathrm{http}$ :/puredata.info/>.

2 No âmbito do Pd, o verbo em inglês to patch remete ao ato de programar, enquanto o substantivo "patch" pode ser compreendido como um programa desenvolvido em Pure Data.
} 


\section{PARTE I - Base Sensorial da \\ Dissonância Musical}

\section{Introdução:}

O conceito, a percepção e interpretação de dissonância sempre foi importante e elementar na teoria e prática musical, igualmente para a musicologia. $\mathrm{O}$ mesmo vale para o conceito complementar de consonância. Afinal, ambos são essenciais na linguagem harmônica e são princípios geradores de contrastes como tensão e relaxamento. Qualquer músico iniciante possui uma noção intuitiva do que é consonância e dissonância e lida com esses conceitos de modo corriqueiro. No entanto, a compreensão teórica aprofundada de como funciona a percepção desses elementos, ou do que realmente se constituem, são problemas mais complexos e próprios da musicologia.

Por mais que seja possível encontrar definições com certas distinções entre consonância e dissonância, faz parte do senso comum que os dois termos descrevam um mesmo fenômeno. Algumas discrepâncias surgem mesmo pelo fato de ser necessário aferir diferentes graus de consonância e dissonância para diferentes intervalos musicais e assim distinguir entre dois grupos principais opostos. Sobre isso, Schoenberg (citado em Tenney 1988 pg. 2) afirma que dissonâncias, mesmo as mais simples, são mais difíceis de compreender que consonâncias, e coloca esse fator como justificativa pelo grau de aceitação de dissonância ter mudado no decorrer da história.

Esse exemplo já nos traz algumas complicações envolvendo o conceito de consonância e dissonância, que será melhor definido adiante. Por enquanto, é necessário afirmar que adotamos uma abordagem que não diferencia conceitualmente a consonância de dissonância, tampouco pretende delinear uma fronteira entre esses dois opostos. Logo, quando falamos de dissonância, estamos igualmente falando de uma mesma grandeza, por assim dizer, de consonância, porém diretamente oposta.

Focaremo-nos na grandeza de dissonância. De tal maneira, temos uma consonância máxima - ou dissonância mínima - como ponto de partida, algo como o intervalo de uníssono, e medimos como a dissonância aumenta em função de outros intervalos musicais (diferentemente de uma situação compreendida como mais complicada, de partir de uma dissonância máxima e, aos poucos, tentar diluí-la até 
chegarmos a uma consonância máxima). Esse foco na grandeza de dissonância está em linha com a afirmação de Schoenberg de que é mais fácil entender o que é uma consonância. Portanto, olhamos para o problema como um continuum que vai do consonante - ou menos dissonante - ao dissonante.

Com essa perspectiva, a dissonância pode ser relacionada com uma espécie de "entropia". Inclusive, esse é um conceito por trás de uma das referências desta pesquisa, em que um modelo de "Entropia Harmônica" (Elrich 1997) visa contabilizar a percepção de dissonância.

Quanto ao problema de pesquisa, é preciso olhar para a dissonância como uma qualidade de ordem perceptiva e sensorial. Nesse aspecto, a dissonância é um fenômeno complexo, definido em termos objetivos e subjetivos, que depende de vários níveis, desde o fisiológico até o cognitivo e interpretativo, além de um contexto estético e cultural. Logo, sua abrangência é de natureza interdisciplinar e interessa não somente à teoria musical como também às ciências. Por essa característica pluriforme, esse conceito tem sido investigado sob diversos pontos de vista, por meio de uma abordagem acústica, cultural, filosófica, cognitiva e assim por diante.

Tenney (1988) destaca cinco noções distintas de dissonância: melódica, polifônica, contrapontística, funcional e psicoacústica. Dentre essas, devemos destacar a abordagem psicoacústica, que relaciona atributos acústicos à sensação de dissonância em um nível ainda objetivo, físiológico. Essa noção está perfeitamente de acordo com o que se define aqui como uma Base Sensorial da Dissonância Musical. Não obstante, mesmo definindo esse recorte de pesquisa, entende-se que a Dissonância Musical como um todo ainda se mantém multidimensional e influenciada por diferentes fatores.

Nesta primeira parte, apresentamos um mapeamento da Dissonância Musical sob esse viés sensorial. A seguir, apresentaremos um panorama geral de atributos perceptivos relacionados à dissonância. Após essa etapa, cada atributo perceptivo será descrito e revisado em pormenores, finalizando com a apresentação de seus modelos psicoacústicos. 


\section{Capítulo 1) A Psicoacústica como uma Base Sensorial para a Percepção Musical}

Em musicologia, a grande área da Psicologia da Música estuda a percepção musical e engloba diferentes subáreas, dentre elas a Psicoacústica. Apresentamos quadros gerais do processo de percepção musical e como a Psicoacústica se insere e se compara com outras subáreas. A partir dessa exposição, justificaremos o recorte adotado em psicoacústica para os fins da pesquisa.

Terhardt investigou a percepção de altura e sua relação com a percepção da fala (1974). Nesse estudo, ele adota o conceito de "três mundos" relacionados aos trabalhos de Popper (1972) e Eccles (1973) com a intenção de delinear três instâncias do processo de comunicação sonora. A relação entre os mundos e estágios de comunicação se dá da seguinte maneira: 1) Mundo Físico / O som como fenômeno acústico; 2) Entidades subjetivas / A percepção sonora e 3) Informação / Processamento e interpretação da informação sonora captada. Abaixo, uma figura do livro de Parncutt que relaciona essa teoria com a percepção musical.
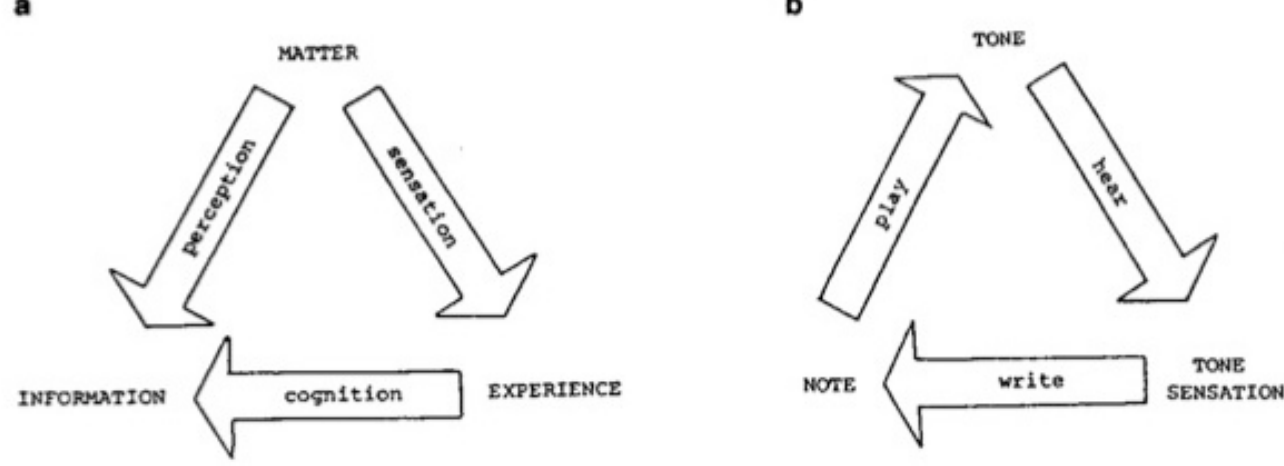

Figura 1 - Interpretação dos 3 mundos na Percepção Musical (Parncutt 1989, p. 22).

$\mathrm{Na}$ figura 1 à esquerda, temos a teoria dos "três mundos": 1) Mundo da matéria; 2) Mundo da experiência e 3) Mundo da informação. Do mundo da matéria ao da experiência temos um processo de "Sensação", enquanto o caminho do mundo da experiência ao da informação contempla um processo cognitivo. Também temos um caminho direto do mundo da matéria ao da informação, em que o processo todo é tido como de "Percepção".

Adaptado ao contexto de percepção musical, à direita da figura 1, temos um 
ciclo, em que o mundo da matéria é o "tom musical" como uma vibração acústica. $\mathrm{O}$ processo de escuta (sensação) leva ao mundo da experiência dado como uma "Sensação Sonora". Essa sensação é codificada em um processo de escrita em uma "Nota" ou partitura, que leva ao mundo da informação. A partir dessa informação, podemos executar e gerar um material sonoro.

Paralelamente, o semioticista e professor de musicologia Jean-Jacques Nattiez (1990) define três instâncias, ou três níveis, em um processo de criação e recepção musical, o primeiro (poiético) diz respeito ao processo criativo; o segundo (neutro) é o dado sonoro bruto; já o terceiro (estésico) depende da interpretação pela escuta. O caminho entre o nível bruto até o estésico contempla o processo de percepção musical.

Simon Emmerson (1982) afirma que os estudos da Psicoacústica e da Cognição Musical são áreas compreendidas como importantes elos na comunicação entre o nível poiético e estésico. Emmerson (1982 p. 72) expande o modelo de Nattiez e o aplica, em especial, à análise de música eletroacústica. Seu trabalho amplia a relação entre o nível neutro e o estésico de Nattiez (1990), e trata a recepção do fenômeno sonoro como uma cadeia de áreas de pesquisa que unem esses polos pelo caminho dado na tabela 1 .

Tabela 1. Relação entre o Nível Neutro e Estésico (Emmerson 1982)

\begin{tabular}{|c|c|c|c|c|}
\hline Nível Neutro & $\begin{array}{c}\text { Análise do } \\
\text { Sinal Físico }\end{array}$ & $\begin{array}{c}\text { Análise } \\
\text { Psicoacústica/Cognitiva }\end{array}$ & $\begin{array}{c}\text { Psicologia da } \\
\text { Música }\end{array}$ & Nível Estésico \\
\hline
\end{tabular}

A distinção feita por Emmerson entre Análise Psicoacústica/Cognitiva e Psicologia da Música diz respeito a uma separação em que a Análise Psicoacústica/Cognitiva tange a um processo central de percepção musical, enquanto a Psicologia da Música trata de processos mentais de ordem superior. E assim podemos relacionar esse caminho com as três instâncias também apontadas por Terhardt (físico - sensações auditivas - informação).

Entretanto, a Psicoacústica e a Cognição são, de fato, subdivisões da Psicologia da Música e possuem competências distintas apesar de se encontrarem em um mesmo estágio no quadro de Emmerson. A seguir, apresentamos melhor a área da Psicoacústica e a distinguimos da Cognição Musical ao expor diferentes níveis de

3 Neste texto, "tom musical" se refere ao material sonoro produzido por instrumentos musicais tradicionais (tons complexos harmônicos). 
percepção musical, que também dizem respeito ao quadro de Emmerson. No final, retomaremos esse quadro frente a outros elementos apresentados no texto.

\section{1 - Psicoacústica}

A psicoacústica é uma área científica que estuda a percepção sonora por meio de testes empíricos, aplicados a um grupo de indivíduos modelo, com análise estatística dos resultados. A Psicoacústica, então, estuda a resposta subjetiva e psicológica de atributos físicos, ou acústicos, do som. A base dessa relação é o mecanismo fisiológico da escuta - entende-se aqui, principalmente, o aparato mecânico do ouvido (externo, médio e interno).

Enquanto a acústica é uma subárea da física que estuda o som enquanto vibração mecânica, a Psicoacústica é considerada como um ramo da Psicofísica. Esta, por sua vez, estuda todas as relações entre estímulos físicos e a nossa percepção através dos sentidos. Entretanto, a Psicofísica também é considerada uma ramificação da Psicologia, que é a grande área que estuda percepção e cognição de um modo geral. Ou seja, a Psicoacústica se configura como uma área híbrida e agrega elementos da Psicologia e da Física.

A formulação do campo da Psicofísica ocorreu no século XIX. Isso significa que as tentativas de explicar fenômenos musicais (como a Consonância e Dissonância) eram, até então, altamente especulativas, muitas vezes com base apenas em alguns preceitos matemáticos, qualificados posteriormente como arbitrários. $\mathrm{O}$ desenvolvimento da Psicoacústica, então, surge como uma possibilidade de fornecer uma base científica para o estudo de percepção musical e até hoje está em ativo desenvolvimento.

Em 1863, o médico e físico alemão Herman Helmholtz, conhecido por contribuições diversas no campo da ciência, publica o original em alemão do livro "Sobre sensações do tom (musical) como uma base psicológica para a teoria da música" (1877). Apesar de não estar explícita no título do livro, a base psicológica a que Helmholtz se refere é a Fisiologia Sensorial, área em que ele também foi um grande expoente.

A Fisiologia Sensorial é justamente a área do estudo de Helmholtz que implica uma abordagem psicoacústica. Até hoje, esse trabalho seminal é uma referência importante na literatura psicoacústica, assim como nesta tese.

$\mathrm{Na}$ época daquela publicação ainda não existia a atual divisão mais refinada 
entre áreas e subáreas do conhecimento humano, como a musicologia e suas atuais ramificações. O título do livro remete apenas a uma aplicação do conhecimento da Psicologia em teoria musical, mas se trata de uma aplicação da Psicoacústica em percepção musical e sua influência em certos aspectos da teoria musical, como o conceito de consonância e dissonância.

A área da Psicoacústica está mais consolidada e bem definida atualmente. Um livro atual na mesma linha de Helmholtz (1877) é o de Parncutt - "Harmonia, Uma Abordagem Psicoacústica" (1989) - já com uma definição mais clara no título sobre o campo de estudo no qual a obra se encontra. Porém, apesar de a Psicoacústica ser uma área híbrida entre Física e Psicologia, as publicações de Helmholtz e Parncutt exemplificam como é possível aplicá-la como uma subárea da musicologia.

Em suma, a psicoacústica é uma área híbrida. Por um lado, ela diz respeito à acústica, que é um ramo da física. Por outro, ela trata da recepção do estímulo físico e sua relação com um objeto sensorial. No que diz respeito à sua aplicação em musicologia, a psicoacústica se encontra na área da Psicologia da Música, que estuda percepção e cognição musical de um modo geral. Como uma subárea delimitada, a psicoacústica possui seus limites de abrangência, que serão discutidos melhor a seguir, onde apresentaremos diferentes níveis perceptivos e como a psicoacústica se aloca nesse espaço.

\section{2 - Diferentes Níveis de Percepção}

Como exemplificado por meio do livro de Helmholtz, a Psicoacústica surgiu no século XIX como uma nova forma de estudar percepção musical em um viés científico. Todavia, seguidamente desse marco, outras abordagens paralelas surgiram na área da psicologia que também se voltaram a esse estudo, focando no mesmo objeto, mas sem a preocupação de uma correlação direta entre um estímulo acústico e uma resposta subjetiva.

Uma forma de classificar essas diferentes abordagens é por níveis de percepção. Um nível de percepção que se explica por uma relação fisiológica entre um estímulo e uma resposta subjetiva é dito mais "baixo". Processos de ordem superior, ou cognitivos, se dão envolvendo a recepção e processamento da informação pelo sistema sensorial em processos mentais diversos, assim como sua interpretação e organização de acordo com um fator de treinamento e aprendizado.

A percepção musical envolve tais processos mais complexos, pois depende de 
uma experiência cultural. Logo, como um todo, pode-se dizer que a percepção musical é de uma ordem superior à mera relação fisiológica. Esse fato restringe a Psicoacústica a apenas um estágio do processo de percepção musical.

A Psicoacústica explica, por exemplo, como somos capazes de distinguir certas qualidades sonoras, tais como características espectrais, alturas e intensidade. Mas, já começa a fugir de seu escopo quando se trata de investigar estruturas musicais mais complexas, como a identificação de forma musical.

Seguindo então para outro escopo de ordem superior, temos na Psicologia da Música, por exemplo, a cognição musical, que emprega disciplinas como a Neurociência, e investiga processos mentais no estudo da percepção musical. Não obstante, tanto a Psicoacústica como a cognição musical podem se voltar a um mesmo objeto, como a percepção de timbre. Aliás, alguns dos atributos perceptivos apresentados nesta pesquisa sob a ótica da Psicoacústica também estão sendo investigados em níveis superiores de percepção.

Em relação à Psicoacústica, os trabalhos na área de cognição musical são bem mais recentes e ainda incipientes, pois é um campo que se instaura apenas na década de 1980. Por isso, se encontram em um cenário de árduo debate e revisão de resultados. Inclusive, muitos desses resultados ainda não foram devidamente sistematizados na forma de um modelo, impossibilitando sua incorporação na teoria e prática musical de um modo eficaz, do modo em que buscamos neste trabalho.

Já a contribuição da Psicoacústica em percepção da Dissonância é presente desde Helmholtz (1877) e tem fornecido estudos quantitativos extensos e objetivos em dados generalizados que, por isso, tem sido aplicados em teoria musical há algumas décadas, inclusive de modo criativo como é o foco desta pesquisa. Essa abordagem mais objetiva e generalizada não é, necessariamente, uma restrição, pois permite que seus estudos sejam aplicados igualmente de modo genérico, independente de questões culturais ou estéticas.

Outro fator importante é que a Psicoacústica nos fornece modelos relativamente simples que podem ser implementados computacionalmente na criação de ferramentas de Eletrônica ao Vivo. Logo, por mais que haja alguma restrição, promove-se uma contrapartida providencial no desenvolvimento de ferramentas para computação musical, com aplicações práticas concretas. Por essas razões, nos ateremos à Psicoacústica como área que nos fornece uma Base Sensorial para o estudo da Dissonância Musical, de modo que outras ramificações e linhas da Psicologia da 
Música (como a cognição e neurociência) não serão consideradas.

\section{3 - Diferentes Níveis em Psicoacústica e Descritores de Áudio}

A Psicoacústica se volta para um estágio anterior de percepção, tido como de "nível mais baixo". Porém, vimos que ela pode ter impacto em questões da teoria e prática musical e ainda estudar elementos que são igualmente pesquisados em cognição musical e neurociência. A percepção de dissonância, que possui um caráter rico e multidimensional, inclui esses elementos situados em uma área fronteiriça.

Da mesma maneira que a Psicoacústica pode se voltar a estudos que possuem interseção com níveis superiores, também há um desdobramento na direção oposta, onde nos encontramos com os ditos "Descritores de Sinais" ou "Descritores de Áudio". A descrição de sinal sonoro faz parte da área de pesquisa em música e tecnologia conhecida como Music Information Retrieval (Recuperação de Informação Musical), ou apenas MIR, e se vale de análise direta do sinal de áudio para extração automática de conteúdos sonoros/musicais. Apesar de envolver questões de ordem perceptiva, o conceito implica que tais informações se encontram no sinal sonoro sem a necessidade de aplicação de modelos perceptivos mais complexos (como em Psicoacústica, que seria de ordem superior em relação a esses).

Fato é que quando pensamos nesse tipo de extração automática, dois níveis de descritores (baixo e alto) se distinguem (Amatriain et. al, 2005). Os Descritores de Áudio considerados de baixo nível se relacionam diretamente com o sinal sonoro, sendo definidos por modelos matemáticos sem referências a uma dimensão perceptiva. Para evitar confusão, é bom ressaltar que o "alto nível”, nesse caso, está bem distante de níveis de percepção superiores à psicoacústica. De fato, eles podem se encontrar em outra área fronteiriça oposta, em uma interseção com atributos psicoacústicos.

Os Descritores de Áudio ditos de Baixo Nível são os principais e mais numerosos, mesmo porque a característica principal dos Descritores de Áudio se dá em uma relação extremamente direta e objetiva com o sinal sonoro. Muitas vezes, aliás, usa-se diretamente o termo "Descritores de Baixo Nível" quando se pretende falar de Descritores de Áudio, o que gera uma confusão terminológica. Nesta pesquisa, portanto, adotaremos o termo mais generalizado Descritores de Áudio, para evitar confusão e não entrar no mérito de ser ou não um descritor de sinal de baixo ou alto nível. Em todo caso, e reforçando a ressalva da característica implícita de normalmente não se configurarem como descritores perceptivos, estamos mais interessados nos 
descritores de ordem superior, que se relacionam com a Psicoacústica.

Há estudos detalhados e gerais sobre esses descritores na literatura (Grey 1975, Iverson \& Krumhansl 1993) e aplicações tecnológicas como classificação automática de gêneros musicais (Tzanetakis, Cook 2002) e outras aplicações criativas que veremos no próximo capítulo. A adoção de descritores de áudio faz parte da nossa realidade cotidiana, como no padrão $M P E G-7$ (Linsday, Burnett, Quackenbush, Jackson 2003) que define 17 descritores de baixo nível. O Projeto CUIDADO (Peeters 2003) - Content-based Unified Interfaces and Descriptors for Audio/Music Databases Available Online - contou com pesquisadores envolvidos no desenvolvimento do padrão $M P E G-7$ e estendeu o padrão a 72 atributos.

Nesse perímetro, ressaltamos casos em que os territórios dos descritores de áudio e atributos Psicoacústicos se sobrepõem; Loudness é um exemplo claro, pois corresponde à nossa percepção de intensidade sonora e também faz parte de um dos objetos de Pd desenvolvidos nesta pesquisa. O conceito de brilho é outro exemplo similar e, como veremos, é um atributo perceptivo da Dissonância.

Podemos então refinar e distinguir atributos Psicoacústicos em diferentes níveis, sendo o mais baixo justamente compreendido pelos atributos que podem ser considerados como Descritores de Áudio, ou os que têm sido adotados em MIR. Acima disso, temos atributos Psicoacústicos por excelência, como a sensação de Aspereza (apresentada melhor nas próximas seções) e, acima destes últimos, temos atributos perceptivos mais complexos que já dialogam com outras áreas da Psicologia Musical, como notaremos ser o caso da Percepção de Altura Virtual. Retomamos, então, o quadro de Emmerson com um maior refinamento, em que separaremos a Análise Psicoacústica/Cognitiva em três instâncias, tendo a Psicoacústica uma posição central.

Tabela 2. Revisão do quadro de Emmerson

\begin{tabular}{|c|c|c|c|c|c|}
\hline \multirow{4}{*}{ Nível Neutro } & $\begin{array}{c}\text { Análise do } \\
\text { Sinal Físico } \\
\text { (Descritor de } \\
\text { Áudio de Baixo } \\
\text { Nível }\end{array}$ & $\begin{array}{c}\text { Psicoacústica } \\
\text { (Psico- } \\
\text { fisiológico) }\end{array}$ & $\begin{array}{c}\text { Cognição e } \\
\text { Neurociência } \\
\text { (Processos } \\
\text { Cerebrais) }\end{array}$ & $\begin{array}{c}\text { Outras instâncias } \\
\text { Psicologia da Música } \\
\text { (Processamento e } \\
\text { interpretação de } \\
\text { informação) }\end{array}$ & Nível Estésico \\
\hline
\end{tabular}




\section{Capítulo 2) Conceitos de Dissonância e Relação com Atributos Perceptivos.}

A origem etimológica do termo Consonância é do latim consonare ("soar junto"), o que implica que há uma fusão, ou uma junção entre uma ou mais sonoridades ${ }^{4}$ distintas (e, por outro lado, falta de fusão entre as sonoridades no caso de Dissonâncias). Esse conceito também se relaciona fortemente com o de Harmonia que, por sua vez, descende do grego ( $\alpha \rho \mu$ oví $\alpha)$ e significa "junção", "unidade", "acordo". É comum também a descrição desses fenômenos por meio de termos subjetivos como “eufonia”, ou a qualidade de ser "agradável”. Principalmente esses últimos termos carregam em si um alto grau de subjetividade, que contribui para uma definição vaga dos conceitos.

Apesar de relativamente triviais na vida do músico, Consonância e Dissonância não são fáceis de definir em linhas gerais e seus conceitos têm evoluído em paralelo com a história da música de acordo com cada período e estilo vigente - ao passo que intervalos e acordes, anteriormente definidos como dissonantes, passaram a ser consonantes.

Tenney (1988) adota uma visão criteriosa e busca uma análise distanciada de juízos de valores, o que o ajuda a investigar diferentes conceitos de dissonância e a organizá-los com cuidado. Seu trabalho aponta diversas questões puramente semânticas e encontra confusão e desacordo entre diferentes conceitos, em que o autor clarifica, a partir de contextos históricos, sem apenas atribuir a uma questão cultural o fator essencial da conceitualização de dissonância.

O trabalho de Tenney traz uma revisão crítica pormenorizada dos conceitos de dissonância, organizados em cinco noções distintas, ou categorias, que visam enriquecer a linguagem sem gerar conflitos entre si. São elas: Dissonância Melódica, Polifônica, Contrapontística, Funcional e Psicoacústica. A primeira corresponde à dissonância em um contexto melódico, e o que está em jogo é o grau de afinidade entre alturas $^{5}$ que soam sucessivamente. A segunda noção, polifônica, diz respeito ao caráter sonoro de díades simultâneas (sua fusão, por exemplo) independente de contexto

\footnotetext{
4

O termo Sonoridade adotado nesta pesquisa se refere a um conceito mais amplo do que apenas "tom musical”, o qual se restringe a tons complexos harmônicos, incluindo assim outras formas de configuração sonora.

5 O conceito de Afinidade de Tons é o mesmo retratado posteriormente no modelo de Comonalidade de Altura.
} 
musical, diferentemente da terceira noção, contrapontística, em que o contexto é importante e diz respeito às regras de condução de vozes. A quarta noção, funcional, surge com o trabalho teórico de Rameau (1722), que dá origem ao conceito de harmonia funcional em música tonal, em que notas de um acorde com forte relação harmônica com um baixo fundamental são definidas como consonantes ${ }^{6}$.

A quinta e última noção de dissonância é a psicoacústica e traz implicações especiais. A primeira é que uma sonoridade em si - fora de um contexto melódico e sem uma justaposição harmônica - pode conter atributos perceptivos dissonantes de acordo com seu conteúdo espectral ${ }^{7}$. Dessa surge outra implicação, em que se precisa considerar o conteúdo espectral de cada sonoridade envolvida em um acorde ou díade, além das relações intervalares em que se encontram.

Por fim, devido a essas nuances, a sensação de dissonância se torna suscetível a pequenas mudanças de acordo com um número maior de variáveis espectrais e, por isso, se qualifica como uma grandeza contínua, enquanto nas noções anteriores a qualidade de consonante/dissonante acaba sendo mais categórica e fixa.

A noção psicoacústica é apresentada por Tenney somente como baseada na sensação de Aspereza. Assim, teve como principal pilar a teoria de Helmholtz (1877), que foi o primeiro autor a lidar com esse atributo. A conclusão do trabalho de Tenney ressalta a importância de buscar correlatos acústicos para diferentes conceitos de dissonância, como os que ele conseguiu isolar e definir.

O trabalho de Tenney possui um esforço de revisão da linguagem e abre margem para uma nova terminologia, busca novas relações e conexões com termos mais detalhados de certas qualidades sonoras, relacionadas com características objetivas físicas e estruturais. $\mathrm{O}$ autor conclui que, nesse caminho, há indícios de que sempre houve uma forte relação entre o que os Iluministas chamaram de "mundo natural" e nossa percepção, teoria e prática musicais (Tenney, 1988 p. 103). Essa relação também é investigada pela Psicoacústica, que é capaz de refinar essas relações e conexões entre qualidades sonoras e conceitos dimensionais de dissonância. A respeito disso, podemos destacar o trabalho de David Huron (2001), que investiga uma relação entre as regras de condução de vozes (a noção de consonância contrapontística) e princípios perceptivos. Huron apresenta então seis desses princípios e como eles se relacionam de

6 Um modelo de Baixo Fundamental, também apresentado e implementado nesta pesquisa, se relaciona com essa noção de Dissonância.

7 Como a relação entre os parciais, energia dos parciais e distribuição dos parciais no registro de frequências. 
diferentes maneiras com a teoria e prática musicais.

Os princípios levantados por Huron (1. Tonalness, 2. Continuidade Temporal, 3. Mínimo Mascaramento, 4. Fusão Tonal, 5. Proximidade de Altura e 6. Comodulação de Altura) apontam para processos cognitivos, não apenas de ordem psicoacústica, ou formalmente modelados para serem implementados em ferramentas computacionais. Em todo caso, esses princípios também são exemplos do tipo de trabalho ao qual Tenney remete como campo futuro de aprimoramento.

Neste texto, traçamos um panorama atual de atributos psicoacústicos relacionados à percepção de Dissonância. O objetivo não é levantar diversos possíveis princípios perceptivos, como o trabalho de Huron, mas, sim, revisar o estado da arte e buscar modelos já formalizados para serem implementados no computador e, assim, gerar e testar ferramentas criativas.

Dentre os princípios apontados por Huron (2001), pudemos implementar em nossa pesquisa apenas o modelo de Tonalness, já que este é o único atributo que possui uma formalização. Não obstante, discutiremos elementos similares, como o de Fusão Tonal, que é um princípio semelhante e algo a ser levado em consideração em pesquisas futuras. Outros elementos implementados e trazidos neste texto fazem parte de um quadro de atributos formulado por Terhardt (1984). 


\section{Capítulo 3) Base Sensorial da Dissonância Musical em Psicoacústica e Seus Atributos}

Partimos da premissa de que a Dissonância, sob um viés sensorial, não se opõe a uma noção mais geral de Dissonância Musical. Essa visão está de acordo com a teoria de Tenney (1988), que não descarta a relação com princípios físicos e objetivos de conceitos de dissonância e conclui, em uma revisão terminológica, que podemos expandir essas relações.

A respeito dos três mundos de comunicação auditiva apresentados anteriormente (vide figura 1), a base sensorial da dissonância musical faz parte do segundo mundo (das sensações auditivas). O quadro da tabela 3 traz essa base sensorial da dissonância como uma instância sensorial intermediária entre o mundo da matéria e da informação, que também diz respeito ao caminho percorrido entre os níveis neutro e estésico (Nattiez 1990).

Tabela 3. Base Sensorial da Dissonância como um mundo de comunicação auditiva

\begin{tabular}{|c|c|c|}
\hline $\begin{array}{c}\text { Matéria/Tom: } \\
\text { Sinal Físico }\end{array}$ & $\begin{array}{c}\text { Experiência/Sensação de Tom: } \\
\text { Base Sensorial da Dissonância }\end{array}$ & $\begin{array}{c}\text { Informação/Nota: Processamento e } \\
\text { interpretação de informação }\end{array}$ \\
\hline
\end{tabular}

Em nosso trabalho, que revisa a exposição de Emmerson (1982) sobre o caminho percorrido entre os níveis neutro e estésico, subdividimos essa instância sensorial em diferentes níveis (vide tabela 2). Porém, a Base Sensorial da Dissonância Musical que apresentamos se restringe ao escopo psicoacústico e seus atributos.

Tenney (1988) define um conceito mais recente de dissonância, apenas definida pela Aspereza, que é um atributo psicoacústico e, por isso, dá o nome de "Dissonância Psicoacústica" a esse conceito. Essa é a única noção trazida por Tenney que foca em uma Base Sensorial da Dissonância Musical e denota um enfoque em psicoacústica. Esta noção está, portanto, perfeitamente alinhada com a Base Sensorial da Dissonância Musical que estamos definindo, mas não adotaremos o termo "Dissonância Psicoacústica" nesta tese e incluiremos outros atributos além da Aspereza. 


\section{1 - Dissonância Sensorial}

Relacionado ao conceito de "Dissonância Psicoacústica" apresentado por Tenney, temos outro termo próprio da Psicoacústica introduzido por Greenwood (1961), denominado "Dissonância Sensorial”. Esse termo possui, igualmente, a Aspereza como seu principal elemento (Terhardt 2000a) e forma um grupo de atributos psicoacústicos (Terhardt 1984).

O interesse primário de pesquisas sob a perspectiva de Dissonância Sensorial é encontrar explicações acústicas e fisiológicas para a dissonância, em uma abordagem generalizada e de baixo nível, passíveis de serem aplicadas a qualquer tipo de sonoridade. Tal nível de generalidade dificulta sua utilização em contextos musicais específicos. Por isso, Terhardt (1984) nos traz um quadro que divide a Base Sensorial da Dissonância Musical em dois grupos de atributos psicoacústicos: Dissonância Sensorial e Harmonia, sendo que este segundo grupo se atém a um contexto e princípios estritamente musicais.

Ambos os grupos e seus atributos serão expostos neste capítulo após introduzirmos e definirmos melhor a Dissonância Sensorial nas duas subseções a seguir, que contrapõem o conceito de Dissonância Sensorial à Dissonância Musical e Sensory Pleasantness.

\subsubsection{Dissonância Sensorial versus Dissonância Musical}

Muitas vezes, quando se fala de Dissonância Sensorial, apenas a Aspereza está em jogo, principalmente em textos mais antigos, em que a Aspereza era o único atributo psicoacústico considerado para explicar a Dissonância sob um viés sensorial. Isso gera alguma confusão, pois resulta em uma relação quase sinonímica entre Dissonância Sensorial e Aspereza que, em certa medida, ainda prevalece ${ }^{8}$. Não obstante, em trabalhos mais recentes, alguns autores incluem outros atributos psicoacústicos à Dissonância Sensorial. Esse é o caso do trabalho de Terhardt (1984), que define a Dissonância Sensorial pelos atributos de Brilho, Tonalness e Aspereza e é uma referência principal desta tese.

O termo "Dissonância Sensorial" surgiu na década de 1960 para se distinguir da noção de "Dissonância Musical", claro que sem levar em conta o estudo posterior e pormenorizado de diferentes conceitos de Dissonância levantados por Tenney (1988).

\footnotetext{
8 Lembramos que o texto de Tenney é relativamente atual, do final da década de 80 . Nele, apenas a Aspereza aparece como elemento da dissonância dita psicoacústica.
} 
Sendo assim, a noção de "Dissonância Musical", da qual a Dissonância Sensorial se distingue primeiramente, é bem mais generalizada e simplificada.

O problema é que sempre se entendeu que a dissonância como um "todo" não poderia ser apenas explicada pela sensação de Aspereza, ou por uma base sensorial. Eis que surge uma necessidade explícita de distinção categórica entre diferentes conceitos de Dissonância, até então desnecessária. Por não dar conta de explicar a Dissonância Musical como um todo, a Dissonância Sensorial cobre apenas uma porção de sua multidimensionalidade, se reduz a um aspecto científico, psicofísico, alheio a fatores de ordem cultural e estética, por exemplo, que correspondem a dimensões complementares

A noção de Dissonância Sensorial permitiu uma série de estudos perceptivos sobre a dissonância com um viés científico e objetivo, o que instaurou uma dicotomia entre Dissonância Sensorial e Dissonância Musical (que inclui um aspecto cultural). DeWitt e Crowder (1987) mencionam um debate que diz respeito a essa oposição, definido como "racionalistas vs. empiristas", e assim traçam um paralelo que vai até a teoria de números inteiros de Pitágoras, como uma forma "racional" de teorizar sobre leis de consonância, enquanto uma oposição "empírica”, ainda na Grécia antiga, veio de Aristóxeno, que afirmava que o juiz final era o ouvido (a experiência perceptiva) e não os números (uma arbitrariedade teórica).

Um dualismo dessa ordem acabou por colocar a Dissonância Sensorial e a Dissonância Musical em lados opostos. Porém, a real dicotomia está entre o inato versus adquirido, uma vez que a Dissonância Sensorial apenas surge para dar conta de uma dimensão sensorial da Dissonância. Em última instância, o objeto de estudo continua sendo o mesmo: Consonância/Dissonância. Desse modo, é plausível considerar que investigações em áreas diferentes não estejam completamente desvinculadas, desconexas ou antagônicas. Tanto que Tenney foi capaz de reunir esses elementos supostamente antagônicos em uma única exposição.

Outros autores também encontram relações mais estreitas entre Dissonância Musical e Dissonância Sensorial, como (Terhardt 1984; Tramo et al. 2003). Terhardt afirma que mesmo uma suposta dicotomia entre "Dissonância Sensorial" (científica) e “Dissonância Musical" (cultural) não exclui o fato que a Dissonância Sensorial cumpre um papel importante na percepção de Dissonância dita "Musical” (Terhardt 2000a). 


\subsubsection{Dissonância Sensorial versus Sensory Pleasantness}

Consonância/Dissonância são conceitos próprios da musica que costumam ser definidos em Psicoacústica por termos como eufonia e pleasantness (agradabilidade). Dessa forma, julga-se quão agradável ou irritante um som qualquer pode ser, relacionando essa resposta subjetiva a atributos físicos do som. Nesse contexto, diversos estudos foram desenvolvidos completamente desconectados de um contexto musical.

Assim, encontramos pesquisas que avaliam a resposta subjetiva de sons de máquinas, como aspirador de pó, carros e afins. Esse tipo de pesquisa visa, inclusive, permitir a construção e desenho de equipamentos que produzam barulhos menos irritantes, o que, a respeito dos três atributos aqui descritos, significa sons com menos batimentos (Aspereza), maior harmonicidade (Tonalness) e menor energia no registro agudo do espectro (Brilho).

Não está claro ainda como cada atributo da Dissonância Sensorial influencia uma percepção geral de Dissonância Musical. Terhardt (2000b) afirma que, em música, a Aspereza é o elemento mais importante da Dissonância Sensorial e que a Dissonância Sensorial cumpre, sem dúvida, um papel no julgamento de Dissonância em música, mas que apenas contabiliza uma dimensão de Sensory Pleasantness, estando longe de determinar princípios de harmonia, por isso a necessidade de inclusão de um segundo grupo de atributos para dar conta desses princípios. Ao que concerne os atributos da Dissonância Sensorial, Parncutt (1989) afirma que os dois aspectos mais importantes da teoria de Terhardt são a Aspereza e o Tonalness, e simplesmente não menciona o brilho.

Terhardt não apresenta um modelo de Dissonância Sensorial - ou Sensory Pleasantness - bem definido. $\mathrm{O}$ autor tampouco afirma qual exato conceito e modelo de cada atributo deve ser empregado para uma medida de Dissonância Sensorial. Zwicker e Fastl (1999), em contrapartida, definem um modelo de Sensory Pleasantness, que é relacionado com os atributos de Aspereza, Brilho e Tonality (similar a Tonalness). Este modelo poderia ser uma definição completa de Dissonância Sensorial, mas o primeiro problema é que o trabalho desses autores não define - apesar de incluir modelos próprios de Aspereza e Brilho - um modelo claro de Tonality, informando que a medida é simplesmente "subjetiva".

Outra questão é que o modelo de Brilho, segundo os autores, é o atributo que mais tem destaque na medida final, o que gera uma controvérsia com a afirmação de 
Terhardt (2000a), ou entende-se que o modelo não diz respeito a sons musicais - fato confirmado por detalhes a seguir.

No final do livro, os autores indicam uma aplicação de parte do conteúdo apresentado em acústica musical. No caso, trata-se da percepção de dissonância, mas o termo adotado, em vez de Sensory Pleasantness, é Consonância Sensorial (conceito complementar de Dissonância Sensorial). Essa definição de Consonância Sensorial também é baseada em Brilho, Aspereza e Tonalness.

Apesar da falta de uma referência direta, há nessa seção do texto um quadro análogo à teoria de Terhardt (1984) - cujos textos se encontram na bibliografia daquela publicação - que une paralelamente o grupo de atributos psicoacústicos de Harmonia ao de Consonância Sensorial. O termo Consonância Sensorial parece então estar levemente desconexo de Sensory Pleasantness.

Outro termo que ainda figura no texto dessa seção é Tonal Consonance, sem, igualmente, ser definido claramente ou comparado com os dois outros termos. Não obstante, levando em consideração o trabalho de Plomp \& Levelt (1965), a Consonância Tonal pode indicar um sinônimo de Consonância/Dissonância Sensorial.

O livro de Zwicker e Fastl (1999) não possui um interesse inicial em aplicação musical, tanto que a implicação em acústica musical aparece apenas no fim como um possível desdobramento. A exposição de um quadro com os mesmos atributos de Terhardt não inclui um modelo contabilizando como cada fator contribui para a percepção geral de Dissonância em um contexto musical e não remete diretamente ao modelo previamente apresentado de Sensory Pleasantness, confirmando que não se trata de um sinônimo direto de Dissonância Sensorial.

Encontramos também uma relação entre o modelo de Sensory Pleasantness apresentado por Zwicker e Fastl (1999) e uma publicação de Aures (1985a), que apresenta um modelo análogo composto pelos atributos de Brilho, Tonalness e Aspereza, mas o termo usado, em vez de Sensory Pleasantness, é "Eufonia Sensorial". Como ambos termos subjetivos de "Eufonia" e Pleasantness (Agradabilidade) são adotados para descrever a sensação de percepção de consonância, fica claro que os modelos de Sensory Pleasantness/Euphony são equivalentes, fora o fato de ambos modelos serem muito similares.

Por fim, torna-se evidente que Sensory Pleasantness/Euphony não dizem respeito a uma aplicação musical e por isso não se adota $\mathrm{o}$ termo Consonância/Dissonância Sensorial. Esse, por sua vez, apesar de conter os mesmos 
elementos, não possui um modelo bem definido já apresentado na literatura da área, e acaba pressupondo um contexto musical mesmo sendo passível de ser medido em qualquer tipo de som.

\section{2 - Quadro de Atributos de Ernst Terhardt}

Como já exposto, a Dissonância Sensorial surgiu tendo a Aspereza como elemento principal. Terhardt (1984), entretanto, inclui outros atributos nesse grupo. Mas, no sentido de expandir e incluir novos fatores, Terhardt expõe também um segundo grupo chamado "Harmonia". O trabalho desse autor influenciou alguns outros como Parncutt (1989) e é uma importante referência desta pesquisa pelo quadro amplo de atributos psicoacústicos que expõe.

Tabela 4. Atributos Perceptivos da Dissonância Musical segundo Terhardt (1984).

\begin{tabular}{|l|l|}
\hline Dissonância Sensorial: & Harmonia: \\
\hline - Brilho (Sharpness) & - Fundamental do Acorde \\
- Aspereza (Roughness) & - Afinidade de Tons: \\
- Tonalness & Comonalidade de Altura \\
\hline
\end{tabular}

Um ponto importante de distinção entre a Dissonância Sensorial e o grupo "Harmonia" é que a Dissonância Sensorial pode ser avaliada e estudada em qualquer sonoridade, sem a necessidade de um contexto dito "musical". Já os atributos do grupo "Harmonia" acabam sendo os atributos sensoriais da Dissonância Musical propriamente dita - isto é, dependem de sons musicais, aplicados em um contexto musical de Harmonia, como entendido pelo conceito tradicional.

O que o grupo de atributos da Harmonia representa, antes de mais nada, é uma abordagem sensorial para explicar conceitos musicais da própria Harmonia tradicional, ligados ao conceito de Consonância e Dissonância, como na relação com a fundamental do acorde na teoria de Rameau (1722) e relações de similaridade entre notas e acordes.

No decorrer da pesquisa, nos deparamos com muitos trabalhos e modelos dedicados a atributos específicos, como a Aspereza e Tonalness, em que é possível encontrar algumas controvérsias entre diferentes modelos. Em contrapartida, não temos uma completa implementação de um modelo de Dissonância Musical com todos os atributos baseados no trabalho de Terhardt (nem mesmo com outro conjunto de atributos), já que Terhardt não deixa explícito como cada atributo contribui ou deve ser 
contabilizado para a percepção ou medida final de Dissonância. Terhardt apenas possui trabalhos a respeito de alguns atributos, em especial do seu conceito de Virtual Pitch (Altura Virtual). Assim, o quadro de Terhardt é um bom ponto de partida, mas ainda está relativamente em aberto.

Encontramos também alguns elementos que devem ser levados em consideração e que não fazem parte do seu quadro, mas estão fortemente relacionados, como o conceito de Fusão Tonal. Abrimos margem também para alguns elementos fora da literatura clássica da Psicoacústica, mas que podem ser igualmente testados de modo empírico em aplicações criativas. Na próxima seção, esmiuçaremos os atributos aqui apresentados, e também apontaremos esses elementos paralelos.

Tabela 5. Subdivisão dos atributos Psicoacústicos em diferentes níveis de percepção.

\begin{tabular}{|l|l|}
\hline Atributo: & Nível Sensorial: \\
\hline Brilho (Sharpness) & $\begin{array}{l}\text { Interseção entre Descritor de Áudio } \\
\text { de alto nível e Psicoacústica }\end{array}$ \\
\hline Aspereza (Roughness) & Psicoacústico \\
\hline Tonalness \& Harmonia & $\begin{array}{l}\text { Interseção de Psicoacústica com } \\
\text { elementos Psicológicos (Gestalt) }\end{array}$ \\
\hline
\end{tabular}

Sobre a classificação do quadro de Terhardt em diferentes níveis perceptivos, podemos começar pelo conjunto de Descritores de Áudio, que está em um nível mais baixo. Sharpness (Brilho) se encontra aqui, pois é, inclusive, um dos atributos classificados no projeto CUIDADO (Peeters 2004). Já a Aspereza é um atributo de nível mais alto, com uma dimensão de complexidade maior em sua modelagem, e ainda controverso teoricamente. Os elementos seguintes dependem da teoria de Altura Virtual de Terhardt, de uma ordem ainda superior, compreendida como parte de um processo de aprendizado, produto de uma Gestalt auditiva (Terhardt 1974a), inerente a um processo essencial para adquirir a habilidade de identificar sons da fala. 


\section{Capítulo 4) Descrição dos Atributos Psicoacústicos}

Vimos no capítulo anterior a necessidade de uma revisão terminológica para evitar confusão entre termos como Sensory Pleasantness e Dissonância Sensorial. É comum encontrarmos disparidades e incongruências terminológicas dessa ordem em Psicoacústica. Um dos motivos é que sempre estamos lidando, em parte, com alguma definição de ordem subjetiva. Neste capítulo, expomos em mais detalhes a origem e desenvolvimento do conceito por trás de cada atributo no quadro de Terhardt (1984) com o objetivo de evitar confusões conceituais, mas também para dar conta de uma revisão terminológica. Retratamos como os conceitos podem evoluir com o tempo e serem adotados para fins ligeiramente distintos, ou ainda serem reelaborados. Dessa forma, um cuidado especial foi dado a essas questões, antes de buscar modelos psicoacústicos para uma implementação computacional.

\section{1 - Grupo de Dissonância Sensorial}

Esta subseção traz os atributos da Dissonância Sensorial, conforme definida por Terhardt (1984), dependente de três atributos perceptivos: Brilho, Aspereza e Tonalness. Já apresentamos uma definição de Dissonância Sensorial, mas veremos ainda mais detalhes no desenvolvimento do conceito de Dissonância Sensorial na descrição do atributo de Aspereza.

\subsubsection{Brilho}

O Brilho é um atributo perceptivo que se liga diretamente com a quantidade de energia espectral no registro agudo. Em inglês, o termo Brilho pode aparecer como Sharpness. Dentre as diversas inclinações, um dos possíveis significados de sharp é "agudo". Por isso, em música, o termo sharp corresponde a sustenido e indica uma alteração do tom para o agudo.

Em compensação, em português, o termo brilho não remete diretamente a uma tradução de sharpness. Fato é que, além de sharpness, esse conceito pode aparecer como Brightness ou Density, fortemente relacionados com sharpness, ou até mesmo equivalentes (Boring \& Stevens 1936), sendo que Brightness está mais diretamente ligado com a tradução para o português de "Brilho". Na falta de outro termo em português, adotamos o Brilho, mas estamos o definindo claramente em relação ao 
conceito de Sharpness.

Mas Sharpness também remete ao conceito de agudo no sentido de "afiado", "pontiagudo", do latim acum, que é o nome da grandeza que mede o Brilho de um som. Em inglês, usa-se o termo dull como antagônico de agudo para designar um som sem Brilho. Portanto, assim como Consonância e Dissonância, temos o dull e sharp.

Terhardt (1984) adota o termo Sharpness, mas não deixa explícito um modelo ou definição específica desse atributo. Usando como referência o trabalho de Zwicker e Fastl (1999), adotamos o modelo e conceito desses autores.

Normalmente, os modelos de Brilho baseiam-se em dados como o centroide espectral, que é um ponto médio de medidas de energia do espectro (no domínio das frequências). O Brilho chega a ser uma sensação diretamente correspondente à medida de centroide, da mesma maneira que uma relação direta é possível entre frequência e sensação de Altura (pelo menos para um tom puro). A relação similar de Brilho com a percepção de grave e agudo de alturas o coloca como uma espécie de dimensão de Altura para timbre (Cabrera 1999), onde uma nota musical de um timbre pode ser mais "aguda" do que outra nota igual de outro timbre, por possuir mais brilho.

A relação direta de brilho com uma medida simples de energia espectral o torna um modelo relativamente simples. Por isso, esse atributo comumente faz parte do conjunto de Descritores de Áudio.

\subsubsection{Aspereza}

A Aspereza é a principal "explicação científica” para a dissonância. Antes de sua formulação, prevaleceu por séculos a noção de Pitágoras, que relaciona consonância com intervalos formados por proporções de números inteiros pequenos. É somente com Helmholtz (1877) que temos uma reavaliação das observações de Pitágoras junto com um estudo aprofundado das propriedades físicas do som e suas relações com as sensações auditivas. O autor é responsável por uma teoria conhecida como "Teoria de Batimentos", que inclui a Aspereza.

Helmholtz (1877) explicou a sensação de Dissonância pelo não alinhamento de parciais, o que promove batimentos. Assim, dois tons simultâneos são dissonantes caso seus parciais não se alinhem. Parciais não alinhados e muito próximos geram a sensação de Batimentos, em que percebemos claramente um tremolo (flutuação na sensação de intensidade sonora). Essa flutuação ocorre em uma taxa que é a mesma da diferença em Hertz dos dois parciais promovendo os batimentos. Por exemplo, a taxa 
de flutuação entre uma frequência de $440 \mathrm{~Hz}$ e $442 \mathrm{~Hz}$ será de $2 \mathrm{~Hz}$, ou dois ciclos de flutuação por segundo.

Helmholtz cunhou e inseriu na literatura psicoacústica o termo Roughness para a sensação promovida por batimentos rápidos, que surgem após uma taxa de $20 \mathrm{~Hz}$. O termo é traduzido para o português como Aspereza (mas alguns autores também usam "Rugosidade", já que em francês o termo é Rugosité). Em todo caso, sejam as flutuações em taxas lentas ou rápidas, o correlato acústico dos Batimentos ou Aspereza é o mesmo: a Flutuação de Amplitude (Vassilakis 2001), ou ainda a Modulação de Amplitude.

A questão é que, a partir de uma taxa de $20 \mathrm{~Hz}$, o ouvido humano não percebe mais os batimentos como uma variação na intensidade sonora, mas ainda é clara a sensação de interferência causada pela Flutuações "rápidas", e inclusive percebemos novas sensações de Alturas, ditas virtuais na terminologia de Terhardt (2000b).

Os termos Aspereza e Rugosidade denotam essa percepção de irregularidades no som, em uma analogia à sensação tátil. Essa analogia chega a ser muito pertinente, pois no ouvido interno (mais especificamente dentro da cóclea) temos uma membrana que recebe a pressão mecânica (ou seja, de forma literalmente tátil) e a transfere para células nervosas. O percepto contrário da Aspereza (e, por extensão, dos batimentos) foi designado por Smoothness, ou Suavidade em português e explica-se pelo alinhamento de parciais, ou pelo espaçamento de parciais acima de uma taxa que promova a sensação de Batimentos ou Aspereza - taxa esta que Helmholtz acreditava ser fixa, mas cuja premissa foi revisada posteriormente por Plomp e Levelt (1965).

Há uma relação possível entre a teoria de Helmholtz e Pitágoras, uma vez que há um grande alinhamento dos parciais de dois tons simultâneos (complexos e harmônicos) em relações de números inteiros pequenos e também porque o espaçamento dos parciais nesse caso não é próximo o suficiente para gerar Aspereza. Logo, intervalos como o da oitava (2:1) e quinta justa (3:2) são suaves, enquanto intervalos como a segunda maior (9:8) e sétima maior (15:8) são ásperos.

Porém, apesar de a teoria de números inteiros pequenos encontrar uma explicação na Aspereza ou Dissonância Sensorial, o fato é que vale somente para sons complexos que possuem uma Série Harmônica, o que é o caso da maioria dos instrumentos musicais. Portanto, essa relação é falaciosa, já que trata-se apenas de uma coincidência aplicável no caso de tons harmônicos. Aliás, por causa da Aspereza, é possível que uma relação de números inteiros simples como a da oitava soe mais 
dissonante, caso os tons sejam inarmônicos, como exemplifica Sethares (1999). De fato, a teoria de números inteiros simples está mais diretamente ligada a outros fatores perceptivos, como o Tonalness, Afinidade de Tons e Fusão Tonal.

Apesar de contemplar uma objetividade na busca de correlatos físicos, a sensação de Suavidade e Aspereza ainda é descrita em termos de quão agradável ou incômodo (pleasant, unpleasant) um som é a um ouvinte (Terhardt 1984). Esses termos são os mesmos usados para definir a Dissonância Sensorial como um todo aqui temos mais uma confusão, que liga diretamente o conceito de Aspereza com a Dissonância Sensorial.

É bom reforçar como os termos "agradável" ou "incômodo" são empregados em pesquisas da escuta humana completamente fora de um contexto musical, mas para aferir uma resposta sensitiva de um atributo como a Aspereza. Inclusive, a Aspereza é considerada como um atributo auditivo fundamental, junto com a sensação de Altura e Intensidade Sonora (Terhardt 2000b). Também se pode afirmar que, mesmo sendo subjetiva, a ideia de "agradável", ou "incômodo" se refere diretamente à relação objetiva entre a Aspereza e sua sensação, tal como a frequência é o correlato da sensação de Altura dada por termos de "grave" e "agudo".

Mesmo na definição da Aspereza por Helmholtz (1877) e seu papel na percepção de Dissonância Sensorial há uma preocupação em evitar algum mal entendido, separando o conceito objetivo da Dissonância Sensorial de um conceito cultural de Dissonância. Segue uma tradução desta definição:

A combinação [de tons] percebida como mais áspera ou suave que outra depende apenas da estrutura anatômica do ouvido (...). Mas a que grau de Aspereza um ouvinte está inclinado (...) como meio para expressão musical depende do gosto e hábito; por isso a fronteira entre consonância e dissonância tem mudado frequentemente (...) e ainda mudará adiante (Helmholtz 1877: 234-235). ${ }^{9}$

Como Helmholtz apenas foca na sensação de Aspereza, ela se destaca e mantém-se como o único elemento da Dissonância Sensorial. Após Helmholtz, temos inúmeros trabalhos sobre Dissonância Sensorial e Aspereza, mas é apenas no trabalho seminal de testes psicoacústicos de Plomp e Levelt (1965) e Kameoka e Kuriyagawa (1969a, 1969b) que temos não só uma revisão da teoria de Helmholtz, como também um estudo sistemático da percepção de ouvintes em laboratório.

9 Todas as traduções desta tese são próprias do autor. 
Plomp e Levelt (1965) adotaram o termo Consonância Tonal para diferenciá-la da Dissonância Musical. Assim, definiram um conceito de Dissonância Psicoacústica que é sinônimo de Dissonância Sensorial. Veja figura abaixo, com o resultado da média de seus testes. Os dados desta pesquisa ainda são a base principal de toda uma classe de modelos de Aspereza. Uma importante contribuição desses autores está em relacionar as taxas da sensação de Aspereza com a Banda Crítica, contrariando as afirmações de Helmholtz, que definia a máxima sensação de Aspereza em uma taxa fixa em torno de $35 \mathrm{~Hz}$. Veja a figura 2.

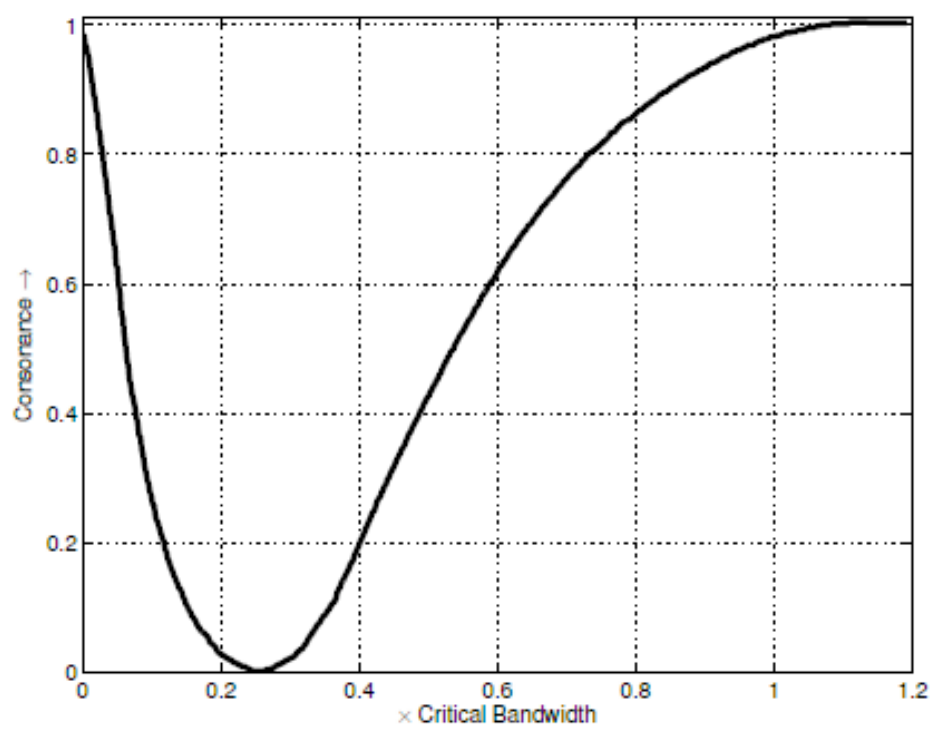

Figura 2 - Dados de Plomp e Levelt (1965)

Plomp e Levelt verificaram que a sensação de Aspereza ocorre apenas em parciais que estejam em uma mesma Banda Crítica. Logo, para parciais distribuídos em intervalos maiores que uma Banda Crítica, não há sensação de Aspereza. Já a sensação máxima de Aspereza se dá em um intervalo que corresponde a um quarto da Banda Crítica. Na figura 2, o eixo vertical é a Consonância (de baixo pra cima) ou Dissonância Sensorial (de cima para baixo), já o eixo horizontal representa uma escala de Bandas Críticas. Uma tabela de valores das Bandas Críticas é apresentada na descrição do modelo de Brilho.

Além do legado de Plomp e Levelt, estudos baseados em Modulação de Amplitude confirmaram seus resultados e produziram detalhes adicionais (Leman 2000). No capítulo 5, trataremos de mais detalhes sobre a modelagem de Aspereza e retomaremos essa apresentação de diferentes fontes de dados e modelos. 


\subsubsection{Tonalness (Clareza de Percepção de Altura)}

Tonalness é uma medida da Clareza de Percepção de Altura. Quanto maior o Tonalness de um som qualquer, mais clara se tem a sensação de uma altura. Tons ditos musicais (ou seja, gerados por instrumentos musicais convencionais) possuem uma clara percepção de Altura e são formados por tons complexos e harmônicos. A ideia de evocar uma clara sensação de Altura significa que uma única Altura é percebida. Mais detalhes sobre esse processo perceptivo dependem do conceito de Altura Virtual que será apresentado na próxima subseção.

Uma maior consonância depende de um alto Tonalness e se relaciona, então, com uma facilidade do sistema auditivo em definir uma altura, enquanto mais de uma altura gera uma complexidade que diminui essa dimensão de consonância, ou a incapacidade de encontrar uma sensação de altura diminui a sensação de Tonalness, e isso promove uma dissonância (Elrich 1997).

Huron (2001) afirma que sonoridades que possuem um alto Tonalness são tons complexos harmônicos (ou seja, tons musicais). A relação entre Tonalness e tons musicais é grande. Inclusive, a etimologia da palavra Tonalness vem da acepção Tonal em música e indica justamente a percepção de um tom musical, uma nota musical, que possui uma percepção de altura clara de acordo com uma frequência de vibração. Nesta tese, portanto, definimos que um som complexo harmônico possui uma qualidade tonal. Há, assim, uma relação com o conceito de Tonalness quando nos referimos a uma qualidade tonal de um som.

Quanto à questão terminológica, Huron (1999) prefere adotar o termo “Toneness", por achar "tone" (de "tom") menos ambíguo e para evitar a relação com a implicação do termo "Tonal” em teoria musical (como Música Tonal). Mas, ao se ater ao termo "tone", ele ainda remete diretamente a tons musicais.

Huron menciona como autores da Psicoacústica também adotaram o termo Tonality para se referir à Clareza de Percepção de Altura (ou seja, Tonalness). Um exemplo da adoção de Tonality está no trabalho de Zwicker e Fastl (1999), mencionado anteriormente no que diz respeito ao Modelo de Sensory Pleasantness. Em compensação, a adoção de um novo termo por Huron apenas inclui mais uma forma de se referir ao conceito, o que pode gerar ainda mais imprecisão.

Fingerhuth (2009) nos traz uma boa revisão sobre a terminologia de Tonalness, e sua pesquisa não diz respeito a sons musicais ou música em geral. Este autor afirma que Tonalness e Tonality podem se referir ao mesmo conceito de Clareza de Percepção 
de Altura, porém também já foram definidos, modelados e adotados de modo distinto.

O autor explica como algumas dessas discrepâncias surgem principalmente em um processo de tradução de e para o alemão. Sobre as discrepâncias de definição, uma se volta mais para aplicações não musicais, como é o trabalho de Hugo e Fastl (1999) e de Aures (1985a), adotado por Fingerhuth (2009). Uma conceitualização e aplicação em música é dada por Terhardt, baseada na sua teoria de Altura Virtual (1982).

Terhardt adota o termo inglês Tonalness, mas o original em alemão (seu idioma materno) é Klanghaftigkeit, um termo que direciona para o som (klang), ou sonoridade em si, em vez de um "tom". Parncutt adota o trabalho de Terhardt como base, mas traduz em um de seus trabalhos o termo Klanghaftigkeit como Sonorousness, que está etimologicamente mais ligado ao termo original em alemão, mas acaba, novamente, incluindo mais uma informação e possível incongruência.

Como não há uma tradução para esse termo no português, preferimos não gerar ainda mais ruído e confusão. Portanto, nos baseamos no conceito original de Terhardt (Klanghaftigkeit), mas adotamos o termo Psicoacústico que é mais comum na literatura; o Tonalness. Talvez a melhor forma de se referir a esse atributo em português seja pela sua própria definição: "Clareza de Percepção de Altura".

O conceito de Altura Virtual é um elemento chave em Tonalness, mas também é um elemento principal na elaboração dos atributos do grupo de Harmonia. A seguir, apresentamos uma melhor definição do conceito de Altura Virtual e expomos sua relação com o conceito de Tonalness.

\subsubsection{Altura Virtual (Virtual Pitch)}

O conceito de Altura Virtual está intimamente ligado à teoria de percepção de altura por si mesma, mais especificamente ao fenômeno em que a percepção de tons complexos pode evocar uma única sensação de Altura, ou ainda mais de uma. A clareza de Percepção de Altura (Tonalness) é uma medida que indica a facilidade, ou clareza, de percebermos nitidamente apenas uma Altura, quando se trata de um som complexo.

Helmholtz (1863) também demonstrou como tons musicais podem evocar mais do que uma única percepção de Altura, ou seja, como é possível perceber não só a frequência fundamental de um tom complexo harmônico, mas também a saliência de alguns dos próprios harmônicos. Helmholtz sugere que escalas musicais se desenvolveram a partir da noção de alturas diferentes possuírem percepções de Alturas 
em comum - conceito que Terhardt denomina de Afinidade de Tons e Comonalidade de Altura.

Helmholtz enfatizou que sua teoria sobre a percepção de harmonia era especulativa, diferentemente da Aspereza. Nessa afirmação, o autor implica que suas hipóteses poderiam não ser verificadas em observações experimentais. Mas, no decorrer do tempo, Terhardt desenvolve seus estudos que revisam a ideia de Helmholtz e apresenta um complemento à teoria se baseando nesse fato mais passível de ser observado e estudado: a Altura Virtual (Terhardt 1974).

Sobre a definição de Altura, a $\mathrm{ANSI}^{10}$ de terminologia psicoacústica estabelece que a "Altura é o atributo auditivo do som, de acordo com o qual sons podem ser ordenados em uma escala do grave ao agudo". Terhardt completa, afirmando que um som pode evocar mais de uma única altura, desde que não seja um tom senoidal.

Terhardt separa a percepção de altura de um tom senoidal da percepção de altura de um tom complexo, denominados, respectivamente, Spectral Pitch (Altura Espectral) e Virtual Pitch (Altura Virtual). Para tons complexos harmônicos, uma sensação de Altura Virtual mais proeminente corresponde à fundamental do tom e é compreendida como a "Altura" desse tom.

Segundo Terhardt (1974a), a percepção de Altura Virtual é ocasionada pelo sistema auditivo ser sensível à periodicidade. Tons puros com uma relação harmônica entre si possuem uma periodicidade igual ao primeiro termo de sua série harmônica, ou fundamental. $\mathrm{Na}$ figura 3, temos uma série com três tons puros, que correspondem aos três primeiros termos da série harmônica $\left(\mathrm{f}_{0}, 2 \mathrm{f}_{0}, 3 \mathrm{f}_{0}\right)$. A soma desses três tons puros possui a mesma periodicidade que a do primeiro termo.

Todavia, em uma relação harmônica entre termos que não incluem a fundamental (como 3, 5 e 8), a periodicidade também corresponde ao primeiro termo da série, pois ele é o máximo divisor comum (MDC). Por exemplo, a soma de dois tons senoidais com valores de $300 \mathrm{~Hz}$ e $500 \mathrm{~Hz}$ (ou seja, na relação harmônica entre 3 e 5) forma uma onda sonora resultante periódica em $100 \mathrm{~Hz}$, seu MDC. Também ilustramos uma relação dessa ordem na figura 4, que traz a soma de tons senoidais na relação harmônica de [3:5:8].

10 Vide $<$ http://pt.wikipedia.org/wiki/American_National_Standards_Institute $>$. 

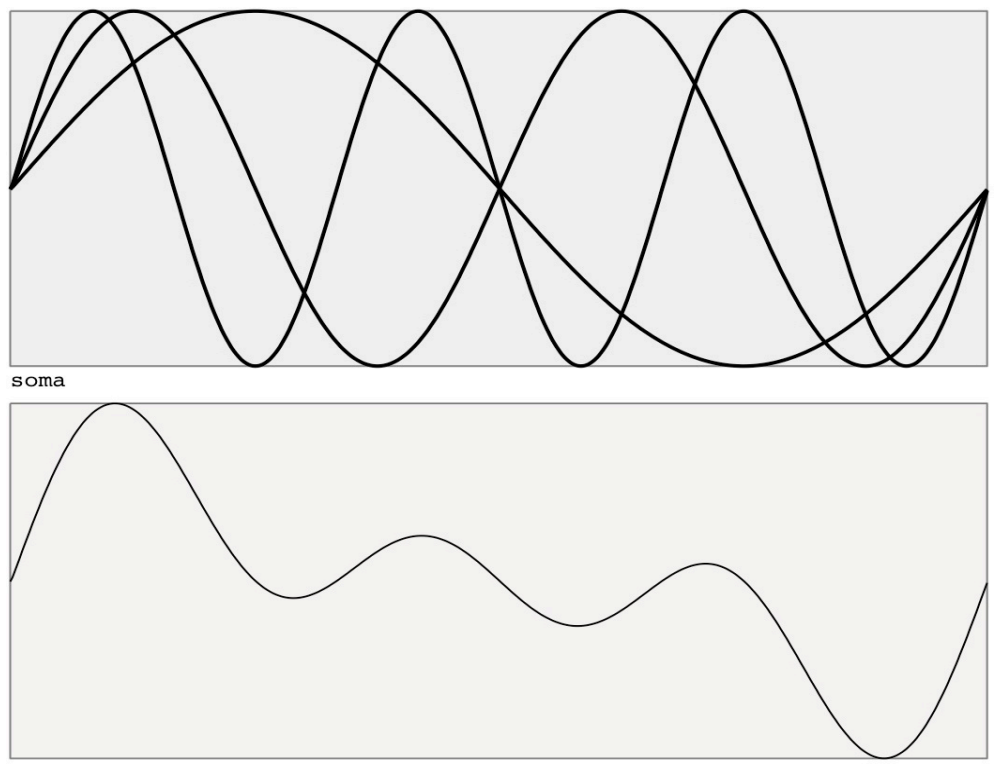

Figura 3 - uma superposição de 3 tons puros em relação harmônica [1:2:3] e a onda sonora resultante da interferência entre eles.
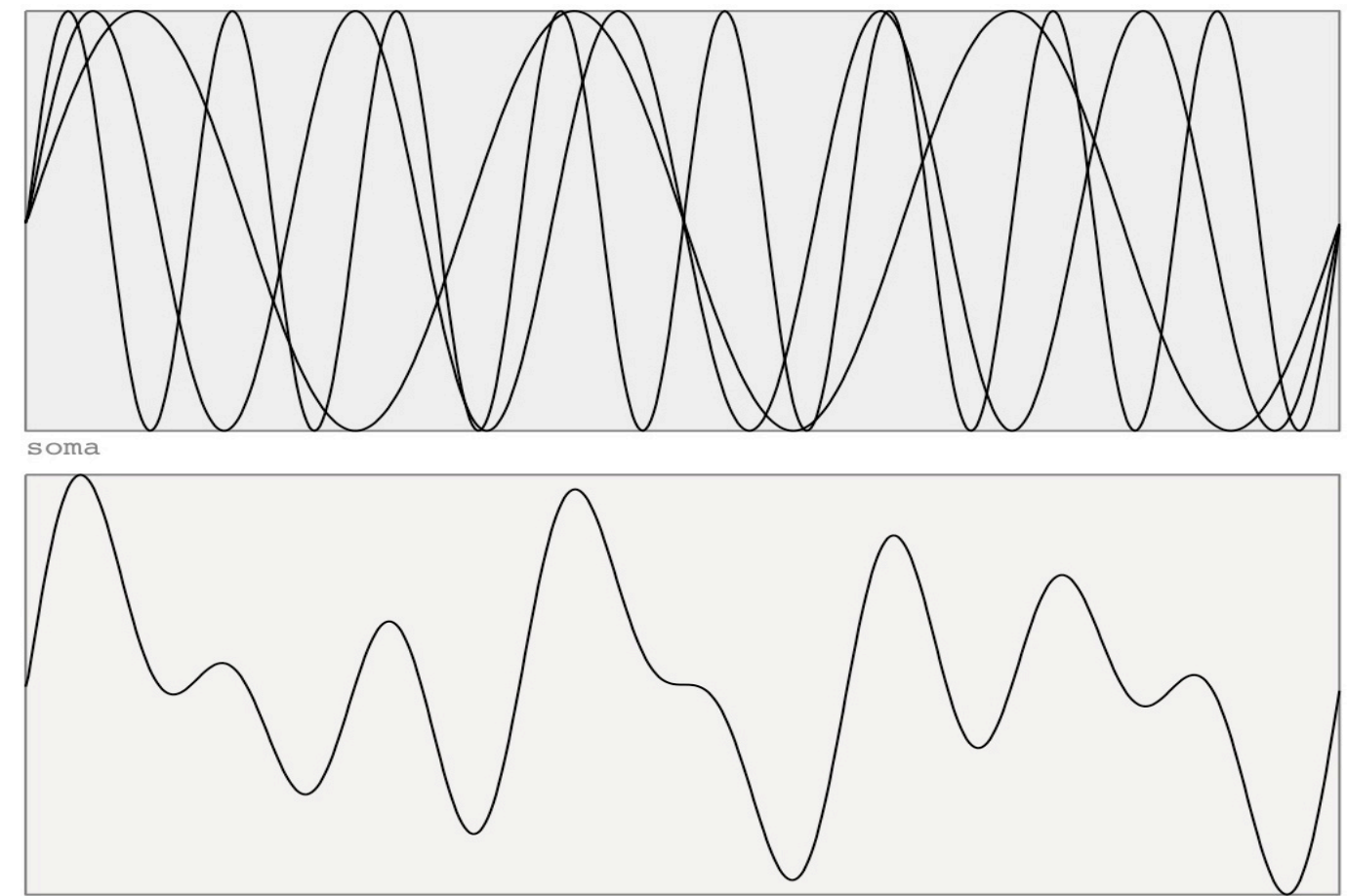

Figura 4 - uma superposição de 3 tons puros em relação harmônica [3:5:8] e a onda sonora resultante da interferência entre eles.

O MDC entre componentes espectrais harmônicos sempre corresponde a uma fundamental, ou a um primeiro termo de uma Série Harmônica, que comporta esses componentes espectrais como seus harmônicos. Por exemplo, $1.200 \mathrm{~Hz}$ e $2.000 \mathrm{~Hz}$ têm como Máximo Divisor Comum $400 \mathrm{~Hz}$. A frequência de $400 \mathrm{~Hz}$ representa o primeiro termo dessa Série Harmônica, enquanto $1.200 \mathrm{~Hz}$ e $2.000 \mathrm{~Hz}$ são, respectivamente, o 
$3^{\circ}$ e $5^{\circ}$ harmônicos $(1.200,400=\underline{3}$ e $2.000,4=\underline{5})$.

Nesse caso, o MDC corresponde à periodicidade da soma dos tons e pode ser considerado uma espécie de subarmônico, ou seja um componente espectral mais grave que faz parte da série (sendo a fundamental, inclusive), que está ausente. Mesmo não estando presente, esse subarmônico representa a percepção de Altura. Esse fenômeno faz parte do conceito de Altura Virtual e é conhecido como Fundamental Ausente.

O conceito de Fundamental Ausente de Terhardt (1974) é uma revisão do conceito de Residue Pitch (Altura Residual) de Schouten (1940), que expõe o fenômeno de um tom complexo harmônico cuja fundamental está ausente, evocando uma altura que corresponde, mesmo que precariamente, à altura dessa fundamental. A percepção de altura de um tom complexo, no conceito de Altura Virtual, não depende apenas do conteúdo espectral, mas de mecanismos cognitivos de ordem superior e sensíveis à periodicidade.

Em linhas gerais, o conceito de Altura Virtual estabelece que, quando o componente espectral correspondente ao primeiro termo da Série Harmônica não está presente no tom complexo, o sistema auditivo, por ser sensível à periodicidade, ainda tem como identificá-lo como fundamental e gerar a percepção de altura que corresponde a esse subarmônico. Quanto menores forem os termos, mais sensível o sistema auditivo é para a periodicidade. Por exemplo, uma relação de [2:3:4] gera uma percepção mais clara de altura que corresponde a uma Fundamental Ausente do que uma relação de [3:5:8]

Terhardt afirma que esse mecanismo é um fato científico que pode ser comprovado em uma simples conversa de telefone, pois a transmissão deste aparelho corta a fundamental da fala humana masculina ${ }^{11}$ e, mesmo assim, mantemos uma mesma percepção de altura. Segundo o autor ${ }^{12}$ :

Na vida real, a percepção de Altura Virtual está longe de ser um fenômeno raro e exótico, ou ainda um tipo de ilusão. Pelo contrário, a percepção de Altura Virtual é mais uma regra do que uma exceção (...) qualquer tipo de som, não importa como foi criado, estimulará o mecanismo auditivo de Altura Virtual a procurar um Subarmônico que corresponda a uma possível altura fundamental (...) periodicidade é uma forte pista para um objeto sonoro (...) é assim que a teoria de Altura Virtual dá conta da determinação de altura e

11 Pelo menos assim o fazia em sistemas telefônicos mais antigos, da época de publicação dos trabalhos de Terhardt.

12

Texto original disponível em <http://www.mmk.ei.tum.de/persons/ter/top/virtualp.hthml $>$. 
segregação de objetos sonoros. (...) Altura Virtual é um rótulo que caracteriza um certo tipo de objeto sonoro, os chamados periódicos, incluindo "supostos" periódicos (supostamente periódicos). Segregação e identificação de objetos sonoros é naturalmente uma das funções fundamentais de qualquer órgão da escuta (Terhardt 2000e).

Esse trecho do texto informa que a periodicidade é uma importante pista na segregação e identificação de objetos sonoros, sendo esse um papel essencial e primário do sistema auditivo. Desse modo, tons complexos e harmônicos se fundem em uma única imagem, e tons inarmônicos geram uma percepção de mais de uma altura, ou uma imagem difusa.

Terhardt (1974) conecta o conceito de Virtual Pitch ao da Totalidade da Psicologia Gestaltiana, que depende de um processo de aprendizado prévio (Lei Gestaltiana da Experiência Passada). O aprendizado prévio do modelo de componentes espectrais harmônicos como um conjunto único, segundo Terhardt, explica-se por ser essencial na habilidade de identificar sons da fala, formada por relações harmônicas. Segundo Terhardt:

Por diversas décadas, a altura tem sido subestimada; primeiramente no que tange sua importância em comunicação auditiva; e, (em segundo lugar), no que diz respeito às dificuldades em compreender sua percepção. No que concerne à comunicação auditiva, foi claramente compreendido que, em música, a altura é a mais importante "portadora de informação". Entretanto, pouca atenção foi dada à possibilidade de que também na "vida ordinária", ou seja, em comunicação pela fala, e em análise auditiva e reconhecimento de uma imensa variedade de sons impingindo sobre nossos ouvidos na vida cotidiana, a altura pudesse ser um elemento chave (Terhardt 2000f).
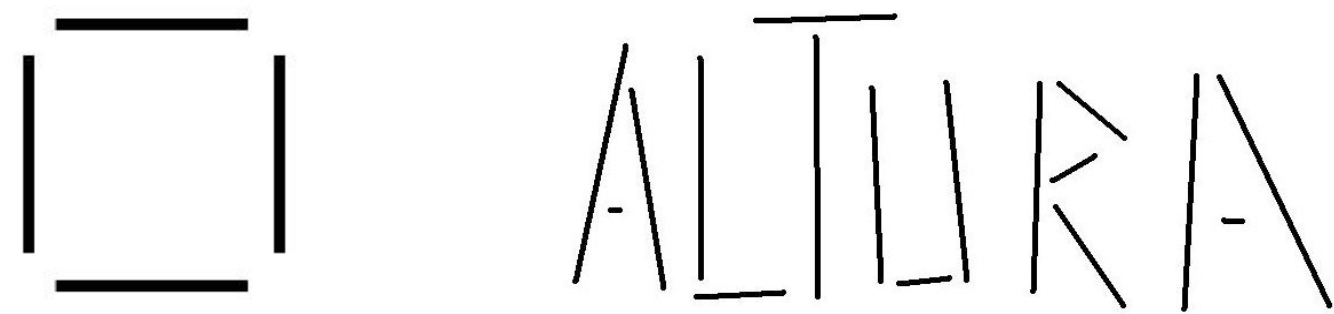

Figura 5 - Princípio da Boa Continuidade. Percebemos um quadrado e a palavra "ALTURA" mesmo com seus contornos incompletos.

Terhardt afirma que esse mecanismo cognitivo de integrar tons puros em uma percepção de uma altura (mesmo quando a fundamental é ausente) corresponde ao modo em que contornos implícitos (lei Gestaltiana da Boa Continuidade) podem ser constatados na visão. Dessa maneira, um conjunto de componentes espectrais 
harmônicos evoca a percepção de uma altura fundamental que, mesmo ausente, pode ser "completada" no processo de percepção.

A percepção de Altura Virtual, ligada ao conceito de periodicidade como elemento chave na segregação e identificação de diferentes objetos musicais, implica que podemos agregá-los também em relações harmônicas, ou seja, relações de números inteiros e consonantes. Desse modo, por exemplo, uma díade com intervalo de oitava pode reforçar uma mesma Altura Virtual. Por isso a Altura Virtual não é apenas um elemento chave para o atributo de Tonalness, mas também para os atributos do grupo de Harmonia, dados a seguir.

\section{2 - Grupo de Harmonia}

Enquanto a Dissonância sensorial trata de atributos sonoros que se aplicam a qualquer som, o estudo perceptivo da Dissonância Musical inclui contextos mais pertinentes e próprios da teoria musical. Em música, a dissonância trata, principalmente, de relações entre dois tons musicais. Tendo como base o estudo de Tenney (1988), quatro conceitos de dissonância levam em consideração esse tipo de relação entre sonoridades (sendo implícita uma relação direta com tons musicais), enquanto o quinto conceito é justamente o da Dissonância Sensorial, passível de ser aplicado a qualquer som de um modo generalizado (o que permite uma noção mais ampla de "sonoridade").

Entre os quatro conceitos anteriores de dissonância, três deles dizem respeito à superposição de sonoridades, o que, em música, se refere ao estudo da Harmonia. Logo, a prática de Harmonia está intimamente ligada a conceitos de Consonância e Dissonância. O estudo da harmonia sob um enfoque perceptivo também começa com Helmholtz (1863), que a define como estudo das "relações entre tons". Parncutt (1989) prefere adotar o conceito mais amplo de "sonoridade", que é bem mais pertinente em uma abordagem psicoacústica.

Essa definição de "Harmonia Sensorial" mantém uma forte relação com a teoria musical de harmonia. O conjunto de fenômenos que corresponde ao que Helmholtz descreveu como "relações entre tons musicais" pode ser explicado, segundo Terhardt (2000c), por dois conceitos: "Fundamental do Acorde" e "Afinidade de Tons: Comonalidade de Altura", que veremos nesta seção.

Esses conceitos também se relacionam com os conceitos de dissonância 
apontados por Tenney (1988). Mesmo o primeiro conceito apontado por Tenney, de dissonância melódica, se baseia na questão de relação de semelhança entre tons sucessivos. Apesar de ser um primeiro conceito de dissonância que surge anteriormente à era polifônica, uma relação consonante se dá por "Afinidade de Tons" (conceito análogo à Comonalidade de Altura). Tenney também afirma que o conceito de Dissonância Melódica permaneceu e foi incorporado em outros princípios harmônicos, como a progressão de acordes segundo uma relação dos baixos fundamentais na teoria de Rameau (1722).

Com essa perspectiva, e deixando de lado o conceito de Dissonância Sensorial, demonstraremos no texto como é possível relacionar todos os outros conceitos levantados por Tenney com os atributos do grupo de Harmonia de Terhardt, apesar de serem apenas dois. Ambos estão também intimamente ligados à percepção de Altura, em especial ao conceito de Altura Virtual.

O modelo de Comonalidade de Altura de Parncutt tem um objetivo final de medir a Comonalidade de Altura, mas como inclui um modelo de Altura Virtual como dado essencial, gera subprodutos como um modelo de Tonalness e Fundamental do Acorde. Apresentamos aqui o conceito desses dois atributos e, no próximo capítulo, uma descrição geral do modelo dado por Parncutt.

\subsubsection{Fundamental do Acorde}

A teoria de Fundamental do Acorde surge com o trabalho do compositor e teórico Jean-Philippe Rameau (1722). O autor foi o primeiro a explicitamente tratar a fundamental de acordes (basse fondamentale) como um percepto auditivo. Um desdobramento da teoria de Rameau é o conceito de inversão de acordes, em que a fundamental do acorde pode não corresponder à nota mais grave. Por exemplo, Sol 4, Dó 5 e Mi 5 é uma primeira inversão da tríade Dó - Mi - Sol.

Terhardt (1974) relaciona o conceito de Rameau à sua teoria de Altura Virtual, que pode ser usada como uma ferramenta para encontrar a fundamental de qualquer tipo de som musical. Isso implica que Terhardt vê em Rameau não apenas um modelo teórico, mas uma teoria com fundamento em uma sensação auditiva.

Vimos que a Altura Virtual está intimamente ligada com uma medida de Tonalness, que, por sua vez, também diz respeito a uma "fundamental". Porém, nesse sentido, a fundamental diz respeito ao primeiro termo de uma Série Harmônica. De 
modo similar, a relação de dois ou mais tons pode ser encarada como uma relação harmônica, em que um desses tons pode possuir a qualidade de ser a fundamental do Acorde.

Por esse motivo, a medida de Tonalness e o modelo de Fundamental do Acorde possuem uma relação muito forte. Enquanto o modelo de Tonalness nos dá um valor que contabiliza a Clareza de Percepção de Altura, o modelo da Fundamental do Acorde nos aponta qual é o tom fundamental. A relação de proeminência, ou prevalência desse tom como fundamental depende da medida de Tonalness.

No caso de medidas de Dissonância Sensorial, tanto um tom como uma díade. ou acorde recebem um valor de estimativa de acordo com cada atributo (Brilho, Aspereza e Tonalness). Já para o atributo de Fundamental do Acorde, para fazer sentido, é preciso que o som analisado seja de uma díade, ou acorde.

No caso de um tom complexo, o modelo afere a fundamental do tom complexo. Todavia, esse princípio pode ser bem interessante se analisarmos tons com fundamental ausente, ou também sons inarmônicos. Mas esse tipo de exploração não tem sido levada em consideração, mesmo porque essa teoria mal tem sido aplicada na prática musical. Nossa pesquisa busca esse desdobramento dos conceitos e modelos psicoacústicos, de modo que apresentamos exemplos dessa ordem na próxima parte desta tese.

Terhardt se fecha no conceito de Rameau, cujo ensejo foi mesmo: o de encontrar supostas leis naturais para explicar princípios da prática musical. Porém, da mesma forma que Pitágoras, seu trabalho possui um grande teor especulativo, já que faltaram ferramentas e conceitos científicos para melhor examinar essas premissas. Terhardt, então, busca aplicar sua teoria para se relacionar com a noção tradicional de Rameau sobre harmonia e consonância/dissonância.

Rameau parte de um conceito próximo ao de Altura Virtual, em que diferentes tons musicais se relacionam uns com os outros por meio de uma fundamental. $\mathrm{Na}$ teoria de Rameau, um acorde é consonante se todos os tons possuem uma forte relação com um baixo fundamental, enquanto notas que não se relacionam formam dissonâncias no acorde. Assim, a inclusão de notas dissonantes abaixa a medida de Tonalness e diminui a proeminência de uma fundamental. Veremos isso em detalhes no próximo capítulo. 


\subsubsection{Afinidade de Tons: Comonalidade de Altura}

O conceito de Afinidade de Tons foca no termo "tom musical", pois é esse tipo de sonoridade que evoca mais Afinidade. O conceito de Afinidade pode ser definido como uma propriedade de uma nota musical ser substituída por outra sem grande diferença no resultado perceptivo. O intervalo musical de maior afinidade é a oitava e, em seguida, a quinta justa. Aliás, Paul Hindemith (1940) afirma que "nada novo emerge" com a relação entre tons na oitava ou quinta, a ponto de a teoria convencional de harmonia não as considerar como díades com função harmônica.

Terhardt (2000d) comenta um aspecto de afinidade auditiva - um molde perceptivo da nossa escuta que nos ajuda a relacionar tons sucessivos em termos de afinidade - como subproduto da exposição à voz humana e sua característica harmônica, mesmo no caso de tons senoidais. Esse aspecto de afinidade auditiva é o mesmo princípio gestaltiano envolvido na percepção de Altura Virtual. Nesse aspecto, parece haver uma pré-disposição perceptiva capaz de fazer correspondências, com facilidade, entre tons musicais que estejam na relação de oitava e quinta. Tons em relação de oitava são, inclusive, compreendidos como equivalentes - fenômeno chamado de Equivalência da Oitava (Terhardt 2000d).

Além desta pré-disposição perceptiva para Afinidades de Tons, Terhardt aponta um segundo aspecto de "Afinidade Sensorial", que se vale do fato de um tom musical poder evocar mais de uma Altura. Esse princípio, igualmente, diz respeito à Teoria de Altura Virtual e é chamado de Multiplicidade de Altura.

Em particular, tons complexos harmônicos (tons musicais) evocam Alturas em relações de números inteiros simples, que são as relações entre os componentes espectrais mais proeminentes. Como consequência, uma "Afinidade Sensorial" entre dois tons complexos e múltiplos emerge do fato de evocarem alturas em comum, fator denominado de Comonalidade de Altura (Pitch Commonality). Para intervalos como a oitava e a quinta, um modelo de Comonalidade de Altura é capaz de encontrar valores altos de afinidade, já que a relação intervalar é a mesma de números inteiros pequenos. Entretanto, o modelo de Comonalidade de Altura pode ser aplicado a qualquer sonoridade.

Esse conceito e modelo depende, então, de uma estimativa de quais alturas uma sonoridade evoca. Essa medida pode também ser gerada a partir de um modelo de Altura Virtual, conforme será apresentado no próximo capitulo. Por isso, o elemento chave da Altura Virtual coloca então esses três aspectos (Tonalness, Fundamental do 
Acorde e Comonalidade de Altura) muito próximos entre si.

A Comonalidade de Altura é uma medida comparativa da afinidade entre duas sonoridades. Até agora, todos os atributos perceptivos que estudamos não partem de um princípio de comparação e podem, portanto, ser analisados a partir de um único espectro. Já a Comonalidade de Altura depende de uma comparação entre pelo menos dois espectros sonoros, mas pode também ser avaliada em um conjunto bem maior de sonoridades.

\section{3 - Considerações Finais e Outros Atributos}

Fizemos uma exposição de todos os elementos da teoria de Terhardt (1984). Na revisão da literatura psicoacústica sobre atributos da dissonância, vimos que a Aspereza é um elemento de destaque, além de ser o primeiro a ser conceituado e desenvolvido. Por essas características, ele acaba sendo o atributo que possui mais detalhes a serem levados em consideração, uma vez que foi abordado em diversos modelos e trabalhos.

Uma expansão de atributos que dizem respeito a uma contabilização de dissonância além da Aspereza é recente e tem em Terhardt seu principal autor. Em uma expansão da Dissonância Sensorial, temos outros dois fatores já apresentados (Brilho e Tonalness). O Brilho se destaca por possuir menos discrepâncias em sua definição terminológica e modelagem, e também por tratar-se de um conceito de um nível mais baixo, mais simples e objetivo, pertencente à literatura e pesquisa em Descritores de Áudio.

Não temos uma real formalização de um modelo de Dissonância Sensorial para música, tampouco um que englobe os parâmetros de Dissonância Sensorial e Harmonia. Fora de um contexto musical, o Brilho assume um importante papel na medida de Dissonância Sensorial, como aponta o modelo de Zwicker e Fastl (1999). Já em um contexto musical, essa dimensão psicoacústica possui uma menor influência, a ponto de nem ter sido mencionada no trabalho de Parncutt (1989), que apenas aponta Aspereza e Tonalness como os "aspectos mais importantes da teoria de Terhardt".

Deixando de lado algumas incongruências terminológicas, o Tonalness é um conceito baseado na teoria de Altura Virtual de Terhardt. Logo, os dados de testes psicoacústicos e a modelagem inicial desse atributo está nos trabalhos de Terhardt (1977, 1979, 1982). Temos um segundo conceito de Tonalness (normalmente com Tonality) baseado apenas na extração de picos de componentes espectrais, que se volta 
mais para estudos psicoacústicos em sons não musicais e faz parte do modelo de “Eufonia Sensorial” (Aures 1985a), que difere do conceito de Dissonância Sensorial aqui apresentado.

O modelo de Tonalness baseado em Terhardt é, portanto, único, ou seja, sem controvérsia em relação a uma outra possível modelagem, ou mesmo sem outras bases de comparação e verificação dos dados. Ele se vale da Altura Virtual, assim como os atributos do grupo de Harmonia, os quais, por consequência, também só possuem esse exemplo de conceitualização e modelagem. Todavia, justamente por isso, cabe-se questionar se outros estudos, validações e abordagens poderiam ser pertinentes.

Relacionado, porém distinto, ao modelo de Terhardt é o conceito de Entropia Harmônica, de Paul Elrich (1997). Futuramente, abordamos esse estudo a título de comparação. Comentamos, também, nesta subseção, outros conceitos de ordem semelhante, que se relacionam com os atributos mencionados, com o intuito de apresentar uma tentativa de expansão do quadro de atributos e a exposição de um panorama mais abrangente.

O fato é que Elrich é um teórico musical e compositor interessado em afinações alternativas, e seu conceito é um modelo especulativo, em vez de um estudo clássico da Psicoacústica. Mesmo assim, entendemos que uma abertura para outros elementos fora do quadro tradicional da Psicoacústica pode servir como enriquecimento da discussão. Outro exemplo de ordem especulativa e arbitrária que mereceu nossa atenção é o trabalho do compositor Clarence Barlow e seu princípio de Harmonicidade. O modelo de Harmonicidade de Barlow foi também implementado nesta pesquisa.

Terminaremos esta seção, entretanto, mencionando um conceito clássico em psicoacústica, que é o princípio da Fusão Tonal. O problema da Fusão Tonal é que ainda não temos uma relação com atributos físicos nem, consequentemente, um modelo, como Sethares aponta em seu trabalho (1999).

Sethares possui um trabalho de Dissonância Psicoacústica baseado apenas em um modelo de Aspereza. Porém, visando ampliar o panorama de abordagens, ele também se refere à Fusão Tonal, ao Tonalness, e a outros dois princípios (tons diferenciais e detecção de pequenos períodos), que o autor acredita serem limitados e fracos, e por isso foram desconsiderados nesta pesquisa. Seguimos então com uma explanação do importante conceito de Fusão Tonal. 


\subsubsection{Fusão Tonal}

O conceito de Fusão tonal se baseia em uma tendência de dois tons musicais se fundirem em uma percepção única, o que ocorre quando o sistema auditivo interpreta certas combinações de frequências como um tom complexo único (DeWitt e Crowder, 1987). Para que isso ocorra, o conteúdo espectral de cada tom e sua justaposição devem formar uma série harmônica, e isso é possível quando temos tons musicais (complexos harmônicos) em relação de números inteiros simples.

No Volume II de seu trabalho seminal Tonpsychologie (1890), Carl Stumpf vê na percepção de tons complexos a base para a consonância musical. O psicólogo alemão propõe uma teoria de Fusão (Verschmelzung) Tonal, que relaciona a sensação de consonância à sensação de percepção de dois tons como uma entidade única.

Há algumas similaridades e correlações entre a teoria de Alturas de Terhardt e o conceito de Fusão Tonal. Schneider e Frieler (2009) comparam, por exemplo, Fusão Tonal, Harmonicidade e Percepção de Altura. Entretanto, isso não implica uma relação direta. Mesmo Terhardt (1974a) menciona a Fusão Tonal sem buscar uma relação com sua teoria de Altura Virtual, e Huron (2001) também traz o conceito de Fusão Tonal separado de uma descrição de Tonalness.

A Fusão Tonal não trata propriamente de uma Altura Virtual que não está presente no espectro, nem de um componente do espectro que se destaca como a altura de um tom e, muito menos, da possibilidade de uma sonoridade evocar múltiplas alturas, e sim justamente o contrário, como duas sonoridades podem se fundir em uma única percepção.

O experimento clássico de Stumpf contou com indivíduos sem treinamento musical e tons puros. Os estímulos de dois tons senoidais, em intervalos musicais diferentes, foram avaliados como um único som, ou dois sons distintos. As respostas dadas como "um único som" apontam para o conceito de Fusão Tonal. Stumpf registra a percepção de "um único som" como uma resposta errada. A tabela 6 é resultado de seu teste.

Tabela 6. Resultados de Stumpf (1890).

\begin{tabular}{|l|l|l|l|l|l|l|}
\hline Intervalo & Oitava & Quinta & Quarta & Terça & Trítono & Segunda \\
\hline \% de Erro & $75 \%$ & $50 \%$ & $33 \%$ & $25 \%$ & $20 \%$ & $10 \%$ \\
\hline
\end{tabular}

A partir desses resultados, Stumpf definiu graus de consonância, baseado na 
possibilidade da Fusão Tonal de um intervalo. O experimento de Stumpf sugeriu que a possibilidade de Fusão Tonal corresponde às proporções de números inteiros pequenos (Modelo Pitagórico), mesmo em tons senoidais.

Em seus trabalhos seguintes, especialmente em Die Sprachlaute (1926), Stumpf demonstrou incerteza sobre o papel da Fusão Tonal na percepção de "Consonância Musical”. Todavia, seu legado foi explorado no século XX em estudos que consideraram o conceito da Fusão Tonal como um fenômeno psicoacústico/cognitivo. A figura a seguir nos mostra uma curva de resultados do trabalho de Stumpf para intervalos musicais descritos em razões de frequências.

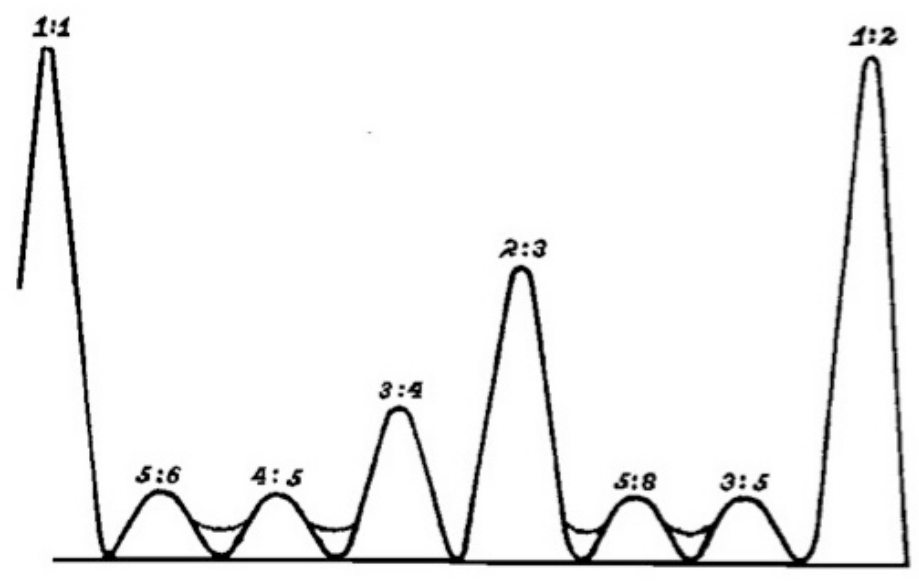

Figura 6 - Curva de Fusão Tonal (Stumpf 1890 II. p. 176)

O conceito de Fusão Tonal recebeu relativamente pouca atenção em Psicoacústica, que teve na Aspereza seu foco principal. A proposta de algum modelo para esse conceito é rara, mas começa a surgir na área de cognição, tal como o trabalho de Ebeling (2009), baseado em periodicidade neural.

Apesar de Terhardt se concentrar na sua teoria de Altura Virtual para explicar a harmonia e a Consonância Musical sob um viés psicoacústico, entendemos que a Fusão Tonal também é um atributo que faz parte da Harmonia e é um elemento complementar à Altura Virtual e suas implicações (Tonalness, Fundamental do Acorde e Comonalidade de Altura). Pelo menos em relação a Aspereza e Brilho, há um claro entendimento da independência destes em relação à Fusão Tonal.

Huron (2001) usa os conceitos de Fusão Tonal e Aspereza como duas dimensões independentes para classificar intervalos musicais. Na terminologia musical tradicional, há três classes de intervalos harmônicos: consonâncias perfeitas (uníssono, 
oitava, quarta e quinta), imperfeitas (terças e sextas maiores ou menores) e dissonâncias (segundas e sétimas maiores e menores e o trítono). Segundo Huron, podemos classificar esses intervalos em critérios de Aspereza e Fusão Tonal, em que consonâncias perfeitas exibem pouca Aspereza e alta Fusão Tonal; consonâncias imperfeitas exibem pouca Aspereza e uma Fusão Tonal comparativamente mais baixa e, por fim, dissonâncias exibem bastante Aspereza e baixa Fusão Tonal.

Podemos ter díades com baixa Aspereza, mas com baixa Fusão Tonal, o que se dá não só em intervalos como a sexta maior, como Huron expôs, mas também no caso de tons inarmônicos em relações intervalares que fogem do temperamento, como no exemplo da "oitava dissonante" de Sethares (1999) ${ }^{13}$. Abaixo, temos diferentes configurações que levam em conta as combinações de Fusão Tonal e Aspereza:

- Baixa Aspereza / baixa Fusão Tonal: Consonâncias Imperfeitas, e "oitava dissonante";

- Alta Aspereza / baixa Fusão Tonal: Dissonâncias;

- Baixa Aspereza / alta Fusão Tonal: Consonâncias Perfeitas;

- Alta Aspereza / alta Fusão Tonal: Sethares e a oitava dissonante;

13 Esse é o primeiro exemplo dado pelo autor em seu livro, que traz em um anexo digital diversos exemplos de áudio e vídeo. Nesse exemplo, um tom inarmônico é tocado em um intervalo de oitava, primeiro melodicamente, e depois harmonicamente. Pela inarmonicidade, os parciais não se alinham na oitava e geram Aspereza. Em seguida, em vez da oitava, o exemplo é de um intervalo um pouco maior, quase uma nona menor, mas em que os parciais se alinham, gerando menos Aspereza. 


\section{Capítulo 5) Modelos Psicoacústicos}

A Psicoacústica não tem na teoria musical seu principal foco, e sim apenas uma possível aplicação que exploramos em nossa pesquisa. Um exemplo do foco real da Psicoacústica é sua contribuição em compressão de arquivos de áudio, como no padrão MP3. Essa é uma grande contribuição da área que obteve um grande impacto em nosso cotidiano, mas que nada diz respeito à teoria ou prática musical.

Esse exemplo é interessante, porque ilustra bem a implicação de conhecimentos da percepção auditiva nesta área. Tendo em vista limitações perceptivas do ouvido humano, é possível eliminar uma grande quantidade de dados da percepção sonora e atingir uma taxa de compressão de até $90 \%$ dos dados digitais de um arquivo sonoro sem uma perda correspondente de qualidades perceptivas.

Essa compressão de dados depende da aplicação de um Modelo Psicoacústico. A ideia de Modelo, na Física, é a formalização de uma teoria, usualmente expressa matematicamente, que está de acordo com a observação em experimentos. Em psicoacústica, há a mesma ideia de modelo, mas os experimentos se configuram como testes psicoacústicos.

Nesta pesquisa de doutorado, implementamos computacionalmente Modelos Psicoacústicos de atributos relacionados à percepção de Dissonância, conforme exposto neste capítulo. O fato é que mesmo um modelo no campo da Física pode ser revisado, assim como a gravidade teve que ser revista após as teorias da relatividade de Einstein. Em Psicofísica, em que lidamos com um maior índice de subjetividade e cognição, parece ainda mais plausível que modelos possam ser revisados, ou ainda serem adotados dependendo do caso, objetivo e conveniência.

No caso de nossa pesquisa, buscamos um objetivo principal de aplicação criativa. Esse propósito claramente gera um contexto que influencia a pertinência e revisão dos modelos psicoacústicos. Essa questão também será abordada nesta tese, mas ainda não consideraremos esse fator neste capítulo, pois ele apenas descreve a formalização dos modelos.

Por enquanto, temos trazido neste texto diversas questões conceituais e terminológicas. Este capítulo ainda retrata questões de uma mesma ordem que surgem na modelagem dos atributos discutidos. 


\section{1 - Modelo de Brilho}

Já informamos anteriormente que os modelos de Brilho (Sharpness) se baseiam em dados do centroide espectral. Em geometria, o centroide é um ponto que define um centro de gravidade, ou centro de massa. O centroide espectral busca um "centro de massa do espectro". Para isso, calcula-se, a partir dos valores de amplitude, uma média ponderada dessa energia. Os pontos do espectro são dados por faixas de frequência que correspondem às bandas críticas. Vimos que a banda crítica também é um dado essencial no modelo de Aspereza, já que é base da curva de Plomp e Levelt (vide figura 2).

As medidas da banda crítica foram obtidas por Zwicker (1961), que adotou o "Bark" como unidade de medida em homenagem a Barkhousen, o criador da unidade de Phon para medir Loudness. Cada Bark corresponde a uma banda crítica. Ao todo, o registro da escuta humana é dividido em 24 Barks.

Tabela 7. Escala Bark em função da frequência (par esquerdo de colunas) e Banda Crítica como função da frequência central (par direito das colunas).

\begin{tabular}{|cc|cc|}
\hline $\begin{array}{c}\text { Escala da } \\
\text { banda crítica } \\
\text { (em Barks) }\end{array}$ & $\begin{array}{c}\text { Escala física (em } \\
\text { Hz) }\end{array}$ & $\begin{array}{c}\text { Faixa de frequência da } \\
\text { banda crítica (em Hz) }\end{array}$ & $\begin{array}{c}\text { Frequência central (em } \\
\text { Hz) da banda crítica }\end{array}$ \\
\hline 0 & 20 & 80 & 60 \\
1 & 100 & 100 & 150 \\
2 & 200 & 100 & 250 \\
3 & 300 & 100 & 350 \\
4 & 400 & 110 & 455 \\
5 & 510 & 120 & 570 \\
6 & 630 & 140 & 700 \\
7 & 770 & 150 & 845 \\
8 & 920 & 160 & 1000 \\
9 & 1080 & 190 & 1175 \\
10 & 1270 & 210 & 1375 \\
11 & 1480 & 240 & 1600 \\
12 & 1720 & 280 & 1860 \\
13 & 2000 & 320 & 2160 \\
14 & 2320 & 380 & 2510 \\
15 & 2700 & 450 & 2925 \\
16 & 3150 & 550 & 3425 \\
17 & 3700 & 700 & 4050 \\
18 & 4400 & 900 & 4850 \\
19 & 5300 & 1100 & 5850 \\
20 & 6400 & 1300 & 7050 \\
21 & 7700 & 1800 & 8600 \\
22 & 9500 & 2500 & 10750 \\
23 & 12000 & 3500 & 13750 \\
24 & 15500 & 4500 & 17750 \\
\hline
\end{tabular}


Cada Bark corresponde a uma faixa de frequência em Hertz, e esses valores não são constantes. A variação da banda crítica gira em torno de uma segunda maior e uma terça menor pela grande maioria do registro, sendo que a banda crítica é bem mais ampla no grave. A relação entre barks e frequência é apresentada na Tabela 7.

$$
\mathrm{S}=0.11 \frac{\sum_{\mathrm{z}=1}^{\text {nband }} \mathrm{z} \cdot \mathrm{g}(\mathrm{z}) \cdot N^{\prime}(\mathrm{z})}{N}
$$

Figura 7 - Equação da Medida de Brilho ( $S$ de Sharpness) em acum. Onde $z$ é o número da banda crítica, $N$ é o loudness total espectro, $N^{\prime}(z)$ é o loudness específico da banda crítica, e $\mathrm{g}(z)$ é uma função que é igual a 1 se $z<15$, e igual a $0.66 \exp (0.171 z)$ para $z>15$.

Como informado na descrição do atributo, a unidade de medida de Brilho é o acum. O valor de 1 Acum é atribuído a uma banda estreita de ruído em torno de $1 \mathrm{KHz}$ com energia de $60 \mathrm{~dB}$. Essa banda estreita corresponde a uma banda crítica (em torno de $160 \mathrm{~Hz}$ segundo a tabela 7). A $1 \mathrm{KHz}$, as medidas em $\mathrm{dB}$ equivalem a medidas em Phons. Portanto, essa definição deixa implícito que 1 Acum é um valor de Brilho que corresponde a uma faixa estreita de ruído qualquer (correspondente às bandas criticas) com intensidade de 60 Phons $^{14}$. Na figura 7, temos a fórmula de Brilho em função da intensidade ou loudness

Os estudos e modelo de Brilho, diferentemente de Aspereza e Tonalness, não foram desenvolvidos para mensurar dissonância em contextos musicais e se valem de uma análise espectral direta de qualquer tipo de fonte sonora. Os outros dois atributos da Dissonância Sensorial possuem uma certa ambivalência e já foram considerados em ambos os contextos, o que também gerou certas discrepâncias em relação à modelagem dependendo de cada caso. Outra consideração importante é que, diferentemente de Aspereza e Tonalness, não é relevante considerar intervalos musicais para medir Brilho, pois pouco importa a relação harmônica, e sim a distribuição de energia no domínio da frequência.

O Brilho possui um especial destaque fora de um contexto musical no modelo de Sensory Pleasantness de Zwicker e Fastl (1999), que é um conceito análogo à Dissonância Sensorial, mas que não busca uma aplicação em um contexto musical. Em

\footnotetext{
14 Mais detalhes sobre Phons na próxima parte, quando apresentamos um objeto que converte medidas em dB para escalas psicoacústicas de intensidade.
} 
contrapartida, não é clara nem bem definida a participação do Brilho na literatura Psicoacústica em um contexto musical. Parncutt (1989), por exemplo, chega a desconsiderá-lo. Traremos mais considerações sobre sua falta de destaque e importância em um contexto musical ao longo do texto.

\section{2 - Modelo de Aspereza}

A Aspereza e o Tonalness podem ser considerados em contextos musicais ou não. No caso de ambos, há estudos que se voltam mais a uma ou outra aplicação. No que diz respeito aos modelos de Aspereza, há basicamente dois tipos: os baseados na curva psicoacústica de Plomp e Levelt (1965) e uma outra classe que se baseia em modelos do processamento auditivo periférico, que literalmente simulam a estrutura do ouvido humano e se relacionam com estudos da área de neurociência, que adotam esse tipo de estrutura para modelagem do sistema auditivo nervoso.

Terhardt (2000b) afirma que uma análise da Flutuação de Amplitude no tempo requer um modelo adequado da excitação da Membrana Basilar. É comum o uso de um banco de filtros (ou canais auditivos) para modelar as bandas críticas e o modo como elas influenciam na análise espectral e no padrão de excitação na membrana basilar. Uma análise com banco de filtros também se aplica como base no modelo de Brilho. O ponto em questão aqui é que esse tipo de estrutura acaba embutindo um certo paradigma de extrair informações diretamente de uma análise sonora sem considerar que tipo de som está sendo analisado. Ou seja, não evidencia um contexto musical. Em compensação, isso não é incoerente, pois os atributos da Dissonância Sensorial estão sujeitos à aplicação em qualquer tipo de entrada sonora, até mesmo ruído.

Como exemplos de uma abordagem desse tipo, temos o trabalho de Aures (1985a), otimizado por Daniel e Weber (1997). Aures (1985a) calcula a Aspereza como uma soma da energia das frequências em batimentos dos canais auditivos (ou banco de filtros). O Modelo de Pressnitzer (1999) é outro exemplo similar, mas que leva em conta os efeitos de comodulação (relações entre os componentes espectrais que possuam a mesma envoltória temporal) em diferentes canais.

Leman, em seu "Modelo do índice de sincronização" (2000), adota o modelo auditivo de Immerseel e Martens (1992), e propõe uma alternativa baseada na ideia de que a Aspereza pode ser contabilizada em termos da energia provida pela sincronização neural das frequências em batimento, em vez da estimativa direta da energia das flutuações. 
Leman (2000) argumenta que essa abordagem possui algumas vantagens porque não possui as limitações de que os modelos baseados em Plomp e Levelt sofrem, uma vez que permite a análise de sons ruidosos e consideram efeitos de fase. Todavia, pode também ser uma limitação o fato de este tipo de modelo apenas lidar com uma análise direta de sinais de áudio no tempo.

Um dos motivos pelos quais os modelos baseados em Plomp e Levelt têm sido usados em aplicações musicais é que podemos nos basear em modelos de espectros (descritos por listas de parciais e amplitudes) e simular situações sonoras e musicais sem a necessidade de ter um sinal sonoro para isso. O próprio Leman reforça esse fato como influência para uma tradição de uso desses modelos em aplicações musicais.

O modelo adotado nesta tese segue uma revisão dos trabalhos baseados em Plomp e Levelt (1965). Basicamente, com a diferença de frequência de cada par de parciais na escala da banda crítica, é possível buscar na curva psicoacústica de Plomp e Levelt um valor de Aspereza para aquele par. Por fim, soma-se o valor de Aspereza de todas as combinações de pares de parciais do espectro. Veremos logo mais a estrutura detalhada do modelo.

No que concerne à fase, Pressnitzer e McAdamns (1999) afirmam que a Aspereza depende deste elemento. Entretanto, Vassilakis ${ }^{15}$ depõe que a ausência da fase no seu modelo (baseado em Plomp e Levelt) não distorce significativamente os seus resultados.

Os modelos baseados em Plomp e Levelt (1965) levam em consideração a extração de picos do espectro, em vez de uma análise do dado bruto. Os picos representam um pequeno número de componentes espectrais ${ }^{16}$, em vez de toda a informação de uma análise espectral que pode chegar a milhares de dados. Este tipo de perspectiva também difere de uma análise por faixas de frequência, que na prática representam apenas recortes dos dados brutos de FFT, e tampouco consideram componentes espectrais.

Um modelo que aceita uma entrada de componentes espectrais (listas de Frequências e Amplitudes) acarreta o fato de lidarmos com um objeto sonoro específico, uma sonoridade. Neste caso, é possível uma abordagem de análise sonora em tempo real, mas também são possíveis abordagens mais abstratas, que permitem

\footnotetext{
15 Vide $<$ http://musicalgorithms.ewu.edu/learnmoresra/moremodel.html $>$.

16 Na segunda parte, apresentamos ferramentas criativas que não precisam de mais do que 50 componentes espectrais para recriar uma sonoridade musical.
} 
simular situações sonoras como a justaposição de espectros, sem que primeiro precisemos gerá-los para então submeter a uma análise da mostra sonora.

Logo, é possível simular e calcular a Aspereza de diversas díades. Em especial, esse tipo de procedimento permite gerar uma Curva de Aspereza, tornando-a uma ferramenta útil para aplicações musicais relacionadas à afinação e microtonalidade, além de outros processos criativos descritos na próxima parte (Barlow 2008, Ferguson 2000, Sethares 1999, Sethares et al. 2009).

Para proceder desta maneira com modelos temporais, seria necessário sintetizar e gerar arquivos sonoros para então inserir no modelo, o que seria mais demorado e complicado. Portanto, para aplicações em tempo real, como na situação de uma performance ao vivo, os modelos baseados em Plomp e Levelt são mais vantajosos.

Os modelos de Aspereza baseados nos dados de Plomp e Levelt (1965) possuem uma mesma estrutura:

- Determinar a diferença de frequência de cada par de parciais;

- Para cada par, buscar o valor de Aspereza na Curva de Plomp e Levelt;

- Aplicar um redimensionamento desse valor de acordo com as amplitudes;

- Somar os valores de cada par.

O modelo, claramente, gira em torno dos resultados da Curva de Plomp e Levelt (1965), apresentada no capítulo anterior (Figura 2). Destacamos duas fórmulas principais que aproximam essa curva, uma fornecida por Parncutt (1993) - usada na sua implementação do modelo de Hutchinson e Knoppoff (1978) e também adotada no modelo de Clarence Barlow (2008) - e outra por Sethares (1999), que foi adotada em seu próprio modelo e também por Vassilakis (2001), que o revisou.

O parâmetro mais controverso e que mais varia de um modelo para outro é como computar a Aspereza para um par de parciais com diferentes amplitudes. Esse é um passo necessário, pois a Curva de Plomp e Levelt (1965) vale apenas para um par de tons senoidais de mesma amplitude. O modelo de Clarence Barlow (2008) destacase por incluir um redimensionamento de acordo com a percepção de intensidade sonora (Loudness) e o efeito de Mascaramento. Já o estudo mais consistente sobre como computar a Aspereza para tons com intensidades sonoras diferentes é o de Vassilakis (2001), que afirma que estudos como o de Terhardt (1974) em modulação de amplitude foram negligenciados na literatura sobre Aspereza e em suas implementações computacionais. A partir disso, Vassilakis desenvolve um modelo de como contabilizar a Aspereza de Amplitudes diferentes por meio do "Grau de 
Flutuação de Amplitude".

Os estudos baseados em Modulação de Amplitude confirmaram os resultados de Plomp e Levelt (1965) e também produziram detalhes adicionais (Leman 2000). Zwicker e Fastl (1999, p.234) descrevem um modelo de Aspereza apenas por esse enfoque e relacionam a Aspereza a três atributos básicos: (i) grau de modulação de amplitude (outro termo para o grau de flutuação de amplitude de Vassilakis); (ii) frequência de modulação e (iii) frequência central. Portanto, apesar de o estudo de Modulação de Amplitude ser paralelo aos modelos baseados em Plomp e Levelt, Vassilakis (2001) foi capaz de acoplar esses estudos nesse tipo de modelo.

Vassilakis insere sua revisão dos modelos baseados em Plomp e Levelt no de Sethares (1999). O modelo de Sethares apresenta certa falta de acuidade na implementação, como, por exemplo, a conversão de frequências em Hertz para Bark e sua aproximação da curva de Plomp e Levelt - questões já discutidas em meu mestrado (Porres 2008). O modelo de Sethares também não possui a inclusão de modelo de mascaramento e loudness, como revisado por Barlow (2008), sendo considerado, por isso, um modelo mais completo.

Frequências

Amplitudes

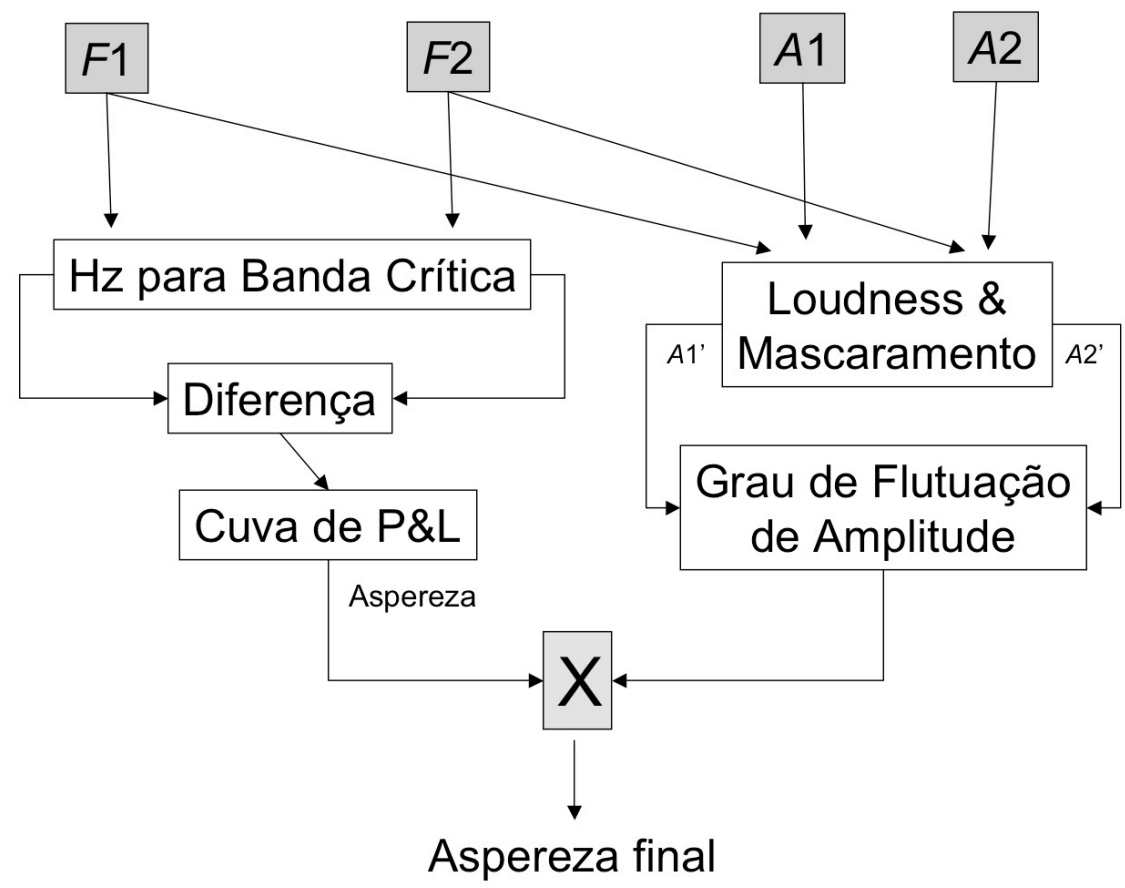

Figura 8 - Diagrama do modelo de Aspereza

Portanto, preferimos tomar o trabalho de Barlow como base de revisão e inserir nele o estudo de Vassilakis. O diagrama da figura 8 traz uma descrição básica dessa 
revisão do modelo de Aspereza, mas apenas diz respeito ao cálculo de Aspereza para um par de componentes espectrais, descritos por uma Frequência e Amplitude (ou seja; F1, A1 e F2, A2). Para contabilizar a Aspereza de um tom complexo ou de uma díade, é preciso levar em conta um passo final de somar os valores de Aspereza de cada par de parciais encontrados no espectro.

O valor máximo de Aspereza é, claramente, arbitrário. A Curva de Plomp e Levelt apenas diz que esse máximo ocorre em um quarto da Banda Critica. Convencionamos que esse valor máximo é igual a 1. Esse valor máximo será redimensionado de acordo com os valores de Amplitudes, sendo que no caso de duas Amplitudes iguais e máximas, a Aspereza deve ser igual a 1.

O modelo de Clarence Barlow não adota a fórmula de Vassilakis (2001), mas um produto da média dos quadrados das Amplitudes em Sones. Excluindo este passo, o modelo proposto continua fiel ao modelo de Barlow, exceto pelo estágio de mascaramento, em que adotamos o modelo de mascaramento existente no modelo de Comonalidade de Altura de Parncutt (1989), ao contrário de Barlow, que implementou um modelo baseado em Zwicker (1999). A conversão de Hertz para a escala da Banda Crítica é a mesma sugerida por Barlow e descrita no capítulo sobre a implementação do objeto em Pd.

Gráficos de Aspereza são comuns na forma de Curvas para intervalos musicais. Pelo fato da importância que esse atributo possui tradicionalmente na contabilização de Dissonância Sensorial, as Curvas de Aspereza também figuram diretamente como "Curvas de Dissonância". Porém, nesta pesquisa, definimos que uma Curva de Aspereza não pode ser considerada uma "Curva de Dissonância", pois, para isso, seria necessária a inclusão de outros atributos aqui expostos (como Tonalness e Comonalidade de Altura).

Deve ficar claro que esse tipo de gráfico é de uma mesma ordem que o gráfico elaborado por Stumpf (1890), apresentado no capítulo anterior na Figura 6, uma Curva de Fusão Tonal, por assim dizer, representando consonância no eixo vertical. A própria curva de Plomp e Levelt (1965) trazida na figura 2 é também apresentada pelos autores como uma curva de Consonância, em que os intervalos de frequência são dados por uma diferença na escala da banda crítica.

O gráfico da figura 9 representa uma Curvas de Aspereza geradas por Helmholtz, com Aspereza no eixo vertical e, no eixo horizontal, intervalos musicais (díades) no espaço de uma oitava, tal qual a Curva de Fusão Tonal de Stumpf (1890). 
A diferença é que os valores no eixo vertical estão invertidos: enquanto medidas de Fusão Tonal correspondem à Consonância, os picos de Aspereza correspondem à Dissonância. Como os tons analisados no gráfico da figura 9 são harmônicos, os parciais se alinham em relações igualmente harmônicas, gerando pontos mínimos de Aspereza. Estes se dão nos mesmos intervalos que os pontos máximos de Fusão Tonal da Figura 6.

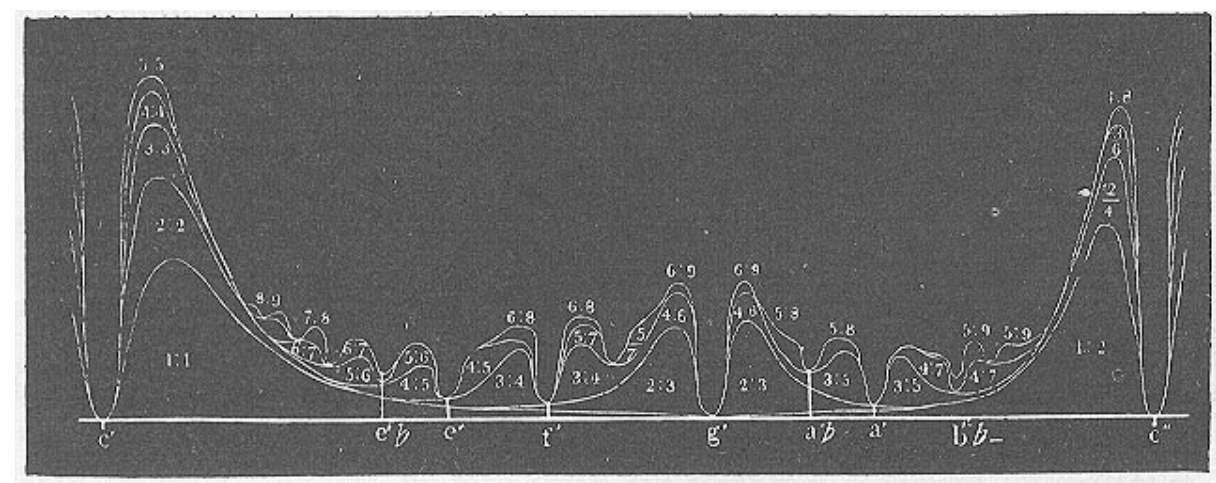

Fig. 6o B.

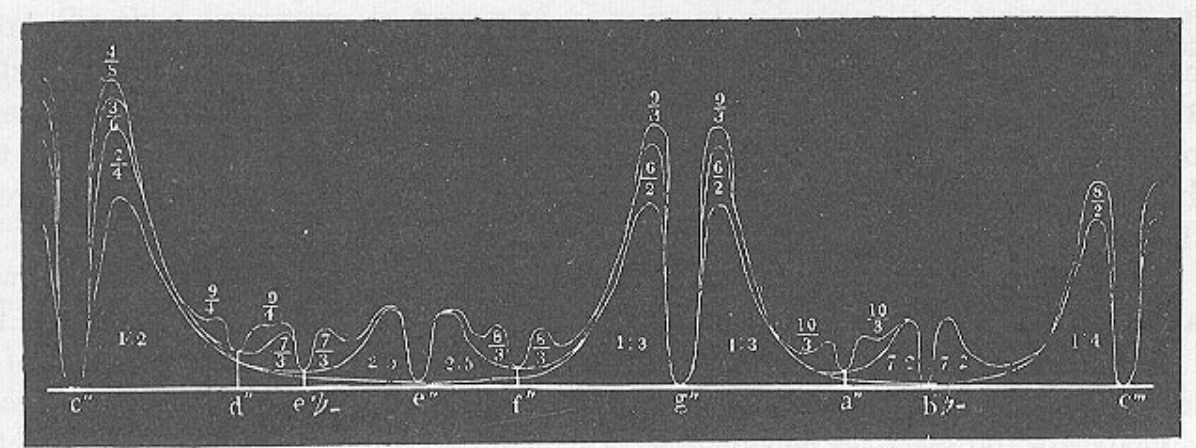

Figura 9 - Curvas de Aspereza de Helmholtz (1877).

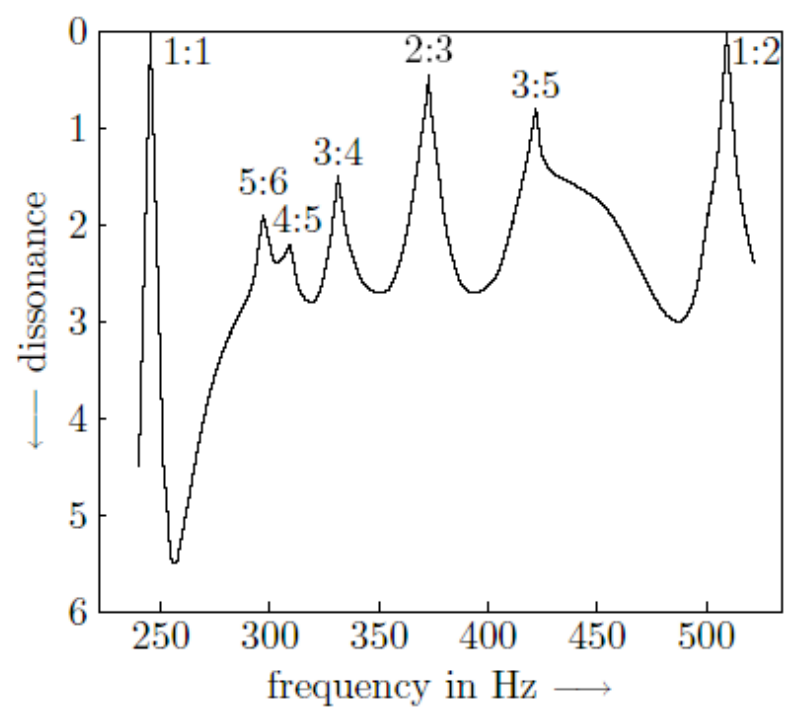

Figura 10 - Curvas de Aspereza de Plomp e Levelt (1965). 
Já a figura 10 apresenta um gráfico similar produzido por Plomp e Levelt (1965). Ao contrário da Figura 9, a Aspereza é dada no sentido contrário, de cima para baixo, e aqui está indicada como Dissonância. Ou seja, os picos representam consonância como na Figura 6. Os intervalos são dados por proporções, e o eixo horizontal representa frequências em Hertz no espaço de uma oitava. O som analisado é formado por 6 parciais harmônicos de igual intensidade. O valor máximo de Aspereza no gráfico da Figura 10 está em torno de 5.5, ao passo que Plomp e Levelt estabeleceram o valor máximo de Aspereza entre dois tons puros igual a 1.

\title{
5.3 - Modelo de Altura Virtual e Tonalness
}

Huron discorre sobre Toneness - seu termo para Tonalness (Clareza de Percepção de Altura) - da seguinte maneira:

\begin{abstract}
A clareza da percepção de alturas tem sido simulada, sistematicamente, em um modelo de percepção de altura formulado por Terhardt, Stoll e Seewan (1982a, 1982b). Para ambos os tons puros e complexos, o modelo calcula um peso de altura, que pode ser entendido como um indício da clareza de altura e, portanto, uma medida de toneness. Para alturas evocadas por tons puros (ditas alturas espectrais), a sensibilidade é mais aguçada na região de dominância espectral - ampla região próxima de $700 \mathrm{~Hz}$. Alturas evocadas por tons complexos (ditas alturas virtuais), tipicamente, denotam o maior peso de altura quando a altura evocada, ou a fundamental verdadeira, encontra-se em uma ampla região, centrada próxima de $300 \mathrm{~Hz}$ - mais ou menos Ré, logo acima do Dó central (C4) (Terhardt, Stoll, Schermbach, \& Parncutt, 1986) (...). Imagens auditivas fortes são evocadas quando tons exibem um alto grau de toneness. Uma impressão clara de um tom musical (como uma imagem nítida) possui um alto grau de toneness, e uma impressão difusa possui um grau baixo de toneness. Uma medida útil de toneness é provida pelo 'Peso de Altura'. Tons possuindo os maiores 'Pesos de Altura' são tons complexos harmônicos centrados na região entre F2 e G5. Tons que possuem parciais inarmônicos produzem percepções de Alturas Virtuais que competem entre si, e então evocam imagens auditivas mais difusas (Huron 2001).
\end{abstract}

Nessa passagem, o autor se refere ao trabalho de Terhardt para definir um modelo de Tonalness baseado em Peso de Alturas (Pitch Weight). Baseamo-nos no Modelo de Tonalness (ou Sonorousness) implementado por Parncutt em seu modelo de Comonalidade de Altura (1989), que remete diretamente à teoria e ao modelo inicial de Terhardt baseados em Pesos de Alturas, e inclui o modelo de Tonalness como um subproduto paralelo.

O modelo de Tonalness pode ser aferido após extraírem-se os valores de Altura Virtual, também necessários para os modelos dos atributos de Harmonia. O modelo de Comonalidade será retomado depois. Todavia, como a dependência é a mesma, seu estágio inicial será descrito aqui já nesta subseção do modelo de Tonalness.

O modelo de Comonalidade de Altura pode ser conferido em detalhes 
diretamente na fonte (Parncutt 1989). Apresentamos aqui apenas uma estrutura generalizada e os passos conceituais essenciais. As implementações dos objetos também são uma fonte de referência e serão dadas em código aberto.

Como o modelo de Aspereza, a entrada de dados são listas de parciais descritas por Frequências e Amplitudes. Mas nesse caso os parciais são aproximados a pontos de uma tabela que, quanto maior for, melhor resolução de frequências terá. O trabalho original de Parncutt nos dá tabelas com 120 pontos, que representam frequências distribuídas em 10 oitavas, cada uma subdividida em 12 semitons do sistema temperado.

O valor de um ponto da tabela é a amplitude do componente espectral que aquele ponto representa. $\mathrm{O}$ primeiro estágio do modelo redimensiona essas amplitudes de acordo com a nossa percepção de intensidade e um modelo de mascaramento.

A partir dessa etapa, temos um estágio que corresponde ao modelo de Altura Virtual, que pode aferir valores desta grandeza para vários pontos da tabela, mesmo alguns que não possuíam valor nenhum de amplitude. Isso porque se trata justamente de um modelo de Altura Virtual que consegue aferir percepção de alturas para componentes espectrais inexistentes. Vejamos o modelo em maiores detalhes:

\subsubsection{Primeiro Estágio: Espectro Audível (Peso de Alturas Espectrais)}

O primeiro passo do modelo é converter as amplitudes em $Y L$ - "Níveis Auditivos" (Auditory Levels), que é o valor em decibéis da diferença entre a amplitude de um parcial e o Patamar do Nível de Audição - LTh (Level Threshold), que, por sua vez, é o nível de intensidade em que começamos a perceber o "som". Trata-se de um procedimento que nivela as amplitudes de acordo com a nossa percepção de intensidade.

O segundo passo é filtrar o espectro em um modelo perceptivo de Mascaramento. O fenômeno de Mascaramento ocorre para componentes espectrais muito próximos, dentro de uma mesma banda crítica, em que um tom pode encobrir outro e até mesmo fazer que a sensação de Altura Espectral promovida por ele não ocorra. Após isso, o que nos resta são as amplitudes descritas em "Nível Audível" (Audible Level). Com esse dado, podemos calcular o Peso de Altura Espectral, ou "Audibilidade". 


\subsubsection{Segundo Estágio: Modelo de Altura Virtual (Pesos de Alturas)}

Esse estágio extrai três tipos de Pesos de Altura que estão diretamente relacionados com a Teoria de Terhardt de Altura Virtual. Terhardt considera dois tipos de Altura, a Espectral e a Virtual. Esta fase calcula o Peso de Altura Espectral (que Parncutt define como Audibilidade de um Tom Puro), o Peso de Altura Virtual (Audibilidade de um Tom Complexo, segundo Parncutt) e um terceiro tipo dado apenas como "Peso de Alturas" (ou Perfil de Audibilidades, de acordo com o autor), que é uma combinação das duas medidas anteriores.

O Peso de Altura Espectral é uma medida de quão audível é uma Altura Espectral em uma sonoridade. A partir das amplitudes de um espectro em "Níveis Audíveis", podemos calcular o Peso de Altura Espectral, que acaba sendo uma grandeza de intensidade sonora subjetiva.

O Peso de Altura Virtual parte da medida de Peso de Altura Espectral, mas depende de uma rotina de varredura do Espectro em busca de um padrão harmônico. No modelo original de Parncutt (1989), temos um molde da série harmônica com 10 componentes. A fundamental do molde percorre o espectro do grave ao agudo. A cada vez que um componente harmônico desse molde da Série Harmônica corresponde a um parcial de fato presente no Espectro, a Altura que corresponde à fundamental ganha um valor de Peso de Altura Virtual de acordo com a medida de Peso de Altura Espectral.

Se há uma correspondência de mais do que um componente espectral com diferentes harmônicos do molde, o valor de Peso de Altura Virtual para essa fundamental é a somatória de todos os valores encontrados, mas cada harmônico é somado com um peso diferente ( $1 / n$, onde $n$ é o número do termo na série harmônica). Assim, se apenas o $8^{\circ}$ e $9^{\circ}$ harmônico de uma fundamental estão presentes, o Peso de Altura Virtual será menor do que caso estivessem presentes o $3^{\circ}$ e $4^{\circ}$ harmônicos.

A grande implicação é que esse procedimento afere valores para fundamentais ausentes - a essência da teoria de Altura Virtual de Terhardt (1974). No caso da fundamental do molde estar presente, seu valor é somado com os valores de outros harmônicos, gerando um resultado maior do que se estivesse ausente. Já quando há apenas um componente como fundamental do molde, seu valor permanece o mesmo.

O Peso de Alturas incorpora todos os Pesos de Altura Virtual encontrados, mas também o compara com os valores de Peso de Altura Espectral em que, no caso de um Peso de Altura Espectral ser maior do que o Peso de Altura Virtual, sua medida 
prevalece. Porém, na maioria dos casos, isso não acontece, donde se pode afirmar que o resultado é, basicamente, o Peso de Altura Virtual.

\subsubsection{Terceiro Estágio: Modelo de Tonalness}

Ambos Pesos de Altura Espectral e Virtual servem de base para calcularmos, respectivamente, o Tonalness Puro e o Tonalness Complexo. Seguindo o modelo de Tonalness de Aures (1985b), Parncutt define o Tonalness Puro de uma sonoridade como uma soma quadrática normalizada dos Pesos de Altura Espectral (para que seu valor máximo seja igual a 1).

Dessa forma, a medida de Tonalness Puro cresce quanto maior for o número e os valores de Peso de Altura Espectral e decresce na medida em que há mais mascaramento entre os componentes. Se estamos comparando o Tonalness Puro de diversas díades, o mascaramento ocorre mais em intervalos dissonantes, em que há um desalinhamento de parciais e os componentes espectrais se encontram em uma mesma Banda Crítica - o que faz que este conceito esteja paralelamente ligado com o de Aspereza.

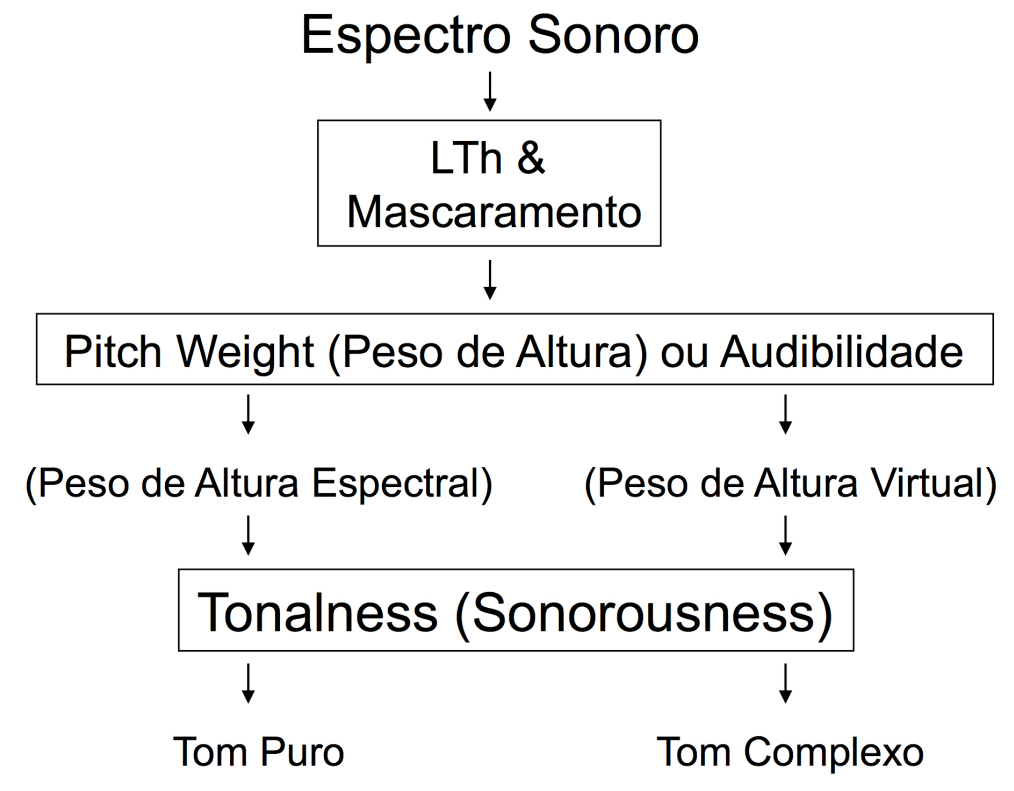

Figura 11 - Diagrama do modelo de Tonalness

Já o Tonalness propriamente dito (Complex Sonorousness) é dado pelo maior Peso de Altura Virtual, também normalizado por uma constante. Como o peso de Altura Virtual cresce de acordo com o reconhecimento de uma Série Harmônica, essa medida está relacionada com a harmonicidade da sonoridade. Dessa forma, o 
Tonalness indica um grau em que uma sonoridade contém um tom complexo harmônico e corresponde a uma medida da facilidade com que a Altura Virtual mais saliente é percebida (Parncutt 1989 p. 59). No caso de díades dissonantes, em relações harmônicas que não são de números inteiros simples (como o velho postulado de Pitágoras), essa medida diminui.

A Figura 11 seguir é um diagrama que resume o modelo de Tonalness, onde primeiro ajustamos a amplitude do espectro de acordo com a percepção de intensidade e o fenômeno de mascaramento. Com o espectro audível, calculamos os Pesos de Altura Espectral e Virtual, que servem para calcular, respectivamente, o Tonalness de Tom Puro e Complexo.

\section{4 - Modelo de Altura Virtual Aplicado aos Atributos de Harmonia}

Parncutt (1989) apresenta um Modelo de Comonalidade de Altura baseado nos estudos teóricos de Altura e Consonância de Ernst Terhardt. Esse modelo foi revisado pelo autor para aplicação em composição musical e apresentado posteriormente com alguns exemplos de análise (Parncutt e Strasburger, 1994). Baseamo-nos nessa última versão, que possui um código original em $\mathrm{C}$, usado também para a compilação de objetos para Pure Data.

O modelo de Comonalidade de Altura consiste, primeiramente, numa comparação entre duas sonoridades. Os dados de comparação são Perfis de Saliência de Altura, que são calculados a partir dos Pesos de Alturas. Como já mencionado, esses dados se baseiam na teoria de Altura Virtual e representam o espectro sonoro de acordo com uma resolução dada. Logo, o Perfil de Saliência será dado em uma tabela com a mesma resolução.

Uma medida de Saliência de Altura significa que percebemos aquela Altura com mais facilidade. O Perfil de Saliência de Alturas de um acorde pode não só conter as próprias notas de um acorde, mas também outras Alturas que podem ser evocadas pelos componentes espectrais do conjunto sonoro, já que parte do processo envolve o modelo de Altura Virtual.

O modelo de Comonalidade de altura é a relação entre o Perfil de Saliência de Altura de dois Espectros Sonoros que podem ser, por exemplo, sucessivos em uma composição. Por isso, esse modelo serve tanto para análise harmônica de uma obra, como também de ferramenta de assistência à composição, que permite ajudar na escolha de uma progressão harmônica. 
Em suma, se dois Espectros ou acordes possuem uma alta Comonalidade de Altura, então ambos evocam sensações de alturas em comum. Logo, ambos produzem Perfis de Saliência de Altura similares. A Comonalidade de Alturas pode explicar, por exemplo, a relação entre os acordes de Dó Maior e Ré menor, visto que, mesmo não contendo notas em comum, esses acordes podem evocar Saliências de Alturas em comum. O modelo possui um subproduto, que calcula a distância de Altura entre duas sonoridades, tendo como base também uma comparação entre as diferentes alturas evocadas pelo Perfil de Saliência de Alturas.

O modelo de Comonalidade de Altura nos dá um tipo de medida harmônica entre duas sonoridades, mas como é baseado em princípios psicoacústicos, ele leva em consideração o Espectro Sonoro e não uma abstração como as notas escritas em uma partitura. Uma segunda implicação importante que o difere de uma análise harmônica em geral é que o modelo não é generalizado em oitavas - uma vez que a percepção sonora varia de acordo com o registro da escuta.

Seguiremos para uma descrição mais detalhada do modelo original de Parncutt e Strasburger (1994), que corresponde à estrutura do programa original em C. Todavia, tomamos aqui a liberdade de organizar a descrição do modelo de um modo diferente, pois também segue nossa estrutura dos objetos de Pd implementados. Continuaremos do ponto em que paramos no modelo de Tonalness e chegaremos até o cálculo de Comonalidade de Altura. Primeiro trataremos de como calcular o Perfil de Saliência de Alturas. Com o Perfil de Saliência de Alturas, é possível também buscar a Fundamental do Acorde, um dos descritores de Harmonia. Outro subproduto dessa seção é a medida de Multiplicidade.

\subsubsection{Descrição Final do Modelo de Comonalidade de Altura}

A Multiplicidade de Alturas é o número de Alturas percebidas em um espectro. Tendo como base o Peso de Alturas (ou Perfil de Audibilidade), uma primeira estimativa é dada por uma soma de todos os pontos da tabela dividida pelo seu maior valor. Após esse passo, o valor de Multiplicidade é redimensionado ao ser elevado a um expoente entre 0 e 1 de acordo com o tipo de escuta, sendo que o valor padrão é 0.5 . Já uma escuta mais analítica tenderia ao valor 1 , enquanto uma escuta holística tenderia a 0 .

Parncutt define a Saliência de uma Altura como a "probabilidade de se percebê-la conscientemente no Espectro Sonoro", em que o termo probabilidade é 
adotado em um sentido subjetivo. Seu cálculo depende do Peso de Alturas e do valor de Multiplicidade calculado. Conclui-se, pela interpretação das fórmulas, que a soma de todas as Saliências de Altura é igual ao valor de Multiplicidade (número de tons simultaneamente percebidos) daquela sonoridade. Em função do Perfil de Saliência de Alturas, o maior valor corresponde à Fundamental do Acorde.

A comparação de dois Perfis de Saliência de Alturas nos dá uma medida de Comonalidade de Altura. Como no exemplo anterior, o Perfil de Saliência de Alturas pode ser uma tabela com 120 valores de Saliência (10 oitavas do sistema temperado). Parncutt adota a correlação de Pearson para contabilizar a Comonalidade, que fornece valores que chegam em um máximo igual a 1 (no caso de espectros iguais) e -1 para sonoridades teoricamente complementares. Veja o diagrama da figura 12 como resumo do processo.

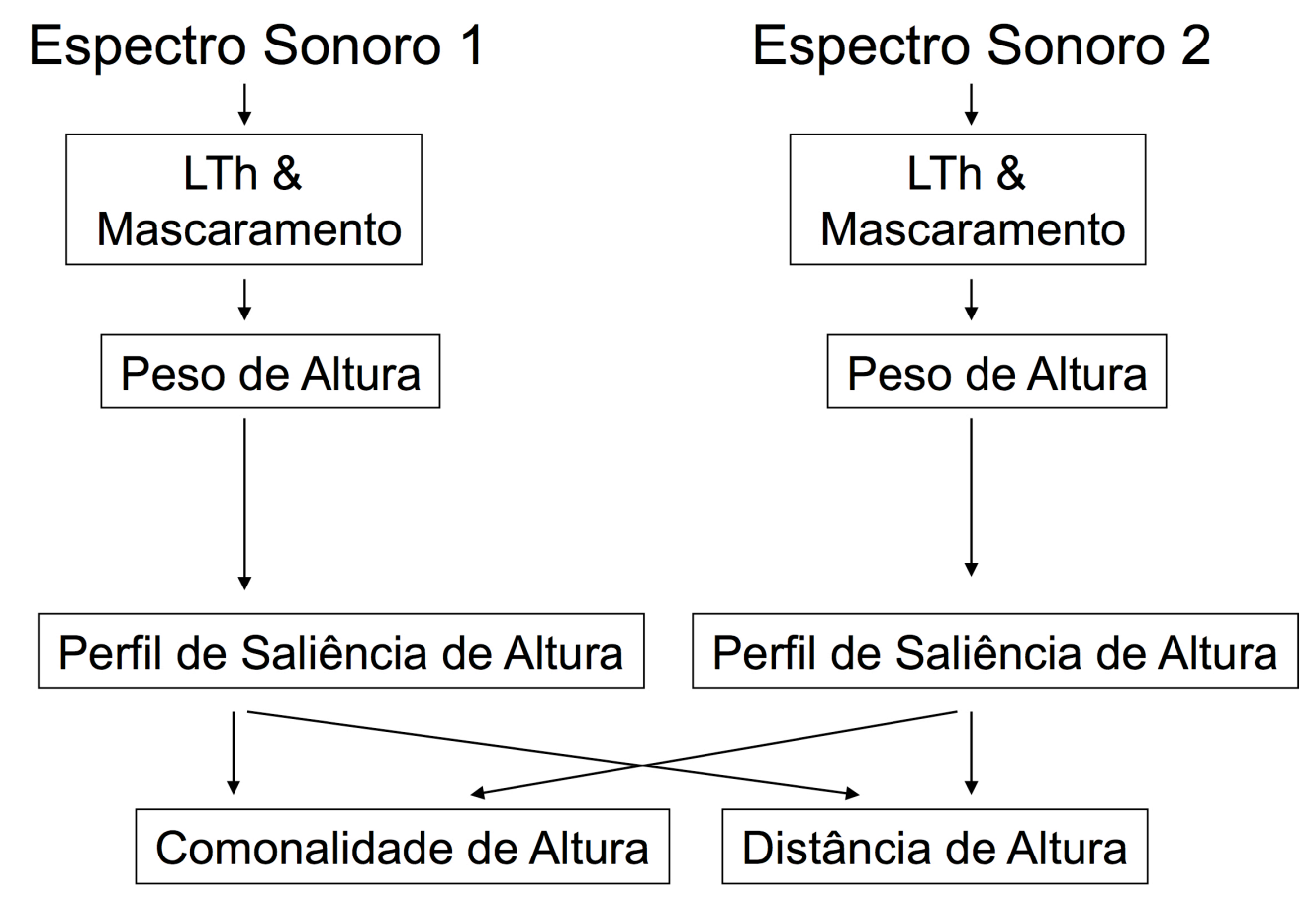

Figura 12 - Diagrama do modelo de Comonalidade de Altura

Um subproduto final do modelo de Comonalidade de Altura de Parncutt (1989) é a distância de altura entre duas sonoridades, dada como uma média das distâncias entre as Saliências de ambos. Essa medida complementar não faz parte dos atributos de dissonância, mas também foi implementada na pesquisa. 


\section{5 - Outros Modelos Relacionados à Harmonia}

A título de exemplo, apontamos dois elementos extras que se relacionam com medidas harmônicas. Eles não podem ser devidamente incluídos no modelo de dissonância porque são, na verdade, modelos arbitrários, e não trabalhos próprios da literatura de Psicoacústica. De todo modo, eles servem como elementos de comparação e de base para uma discussão final entre dados experimentais e uma abordagem empírica.

Outra consideração é que não temos outros modelos dos atributos de Harmonia, a não ser o trabalho de Parncutt (1989) que, por sua vez, é uma revisão da teoria de Terhardt (1984). Portanto, na falta de algo próprio da Psicoacústica, adotamos esses outros modelos como exemplo de contraste.

Nas considerações finais desta primeira parte, tratamos com mais profundidade essa questão de falta de outros trabalhos relacionados à Altura Virtual e os Atributos de Harmonia e trazemos também alguns exemplos da área de Cognição e Descritores de Áudio para a discussão.

\subsubsection{Harmonicidade}

O trabalho de Barlow em seu conceito de Harmonicidade é um exemplo de aplicação de um modelo arbitrário baseado em princípios perceptivos. Veremos, nas considerações finais, que o termo Harmonicidade diz respeito a alguns Descritores de Áudio, mas Barlow o adotou de um modo distinto e particular. O seu modelo de Harmonicidade, baseado em sua teoria e conceito, extrai uma medida de acordo com uma relação harmônica dada por números inteiros (Barlow 1987).

A ideia se vale de princípios puramente matemáticos, que visam medir a complexidade de uma relação numérica. Nesse aspecto, podemos encontrar um ponto em comum com a noção Pitagórica e pensar o conceito de Harmonicidade como sua expansão, em um modelo que, a partir de números, gera uma medida de consonância e harmonia. O modelo é relativamente simples e pode ser consultado em seu artigo (Barlow 1987). O objeto desenvolvido neste trabalho será apresentado também na segunda parte, onde o traremos com mais detalhes. Ele também faz parte do pacote de ferramentas anexas à pesquisa e será distribuído como código aberto.

A medida de Harmonicidade para o uníssono possui um resultado igual a infinito. Após esse intervalo, o maior valor é o da oitava (2:1) igual a 1 . O modelo dá valores positivos quando o tom compreendido como fundamental é o denominador. 
Logo, se temos a inversão da oitava dada como (1:2), o valor é de -1. A quinta (3:2) dá um valor de 0.272727 , e a quarta (4:3) dá um valor negativo, por ser considerada uma inversão da quinta, com o resultado de -0.214286 . O modelo pode ser expandido e dar a relação harmônica de uma sonoridade, simplesmente ao somar o valor absoluto de harmonicidade de todas as combinações de parciais.

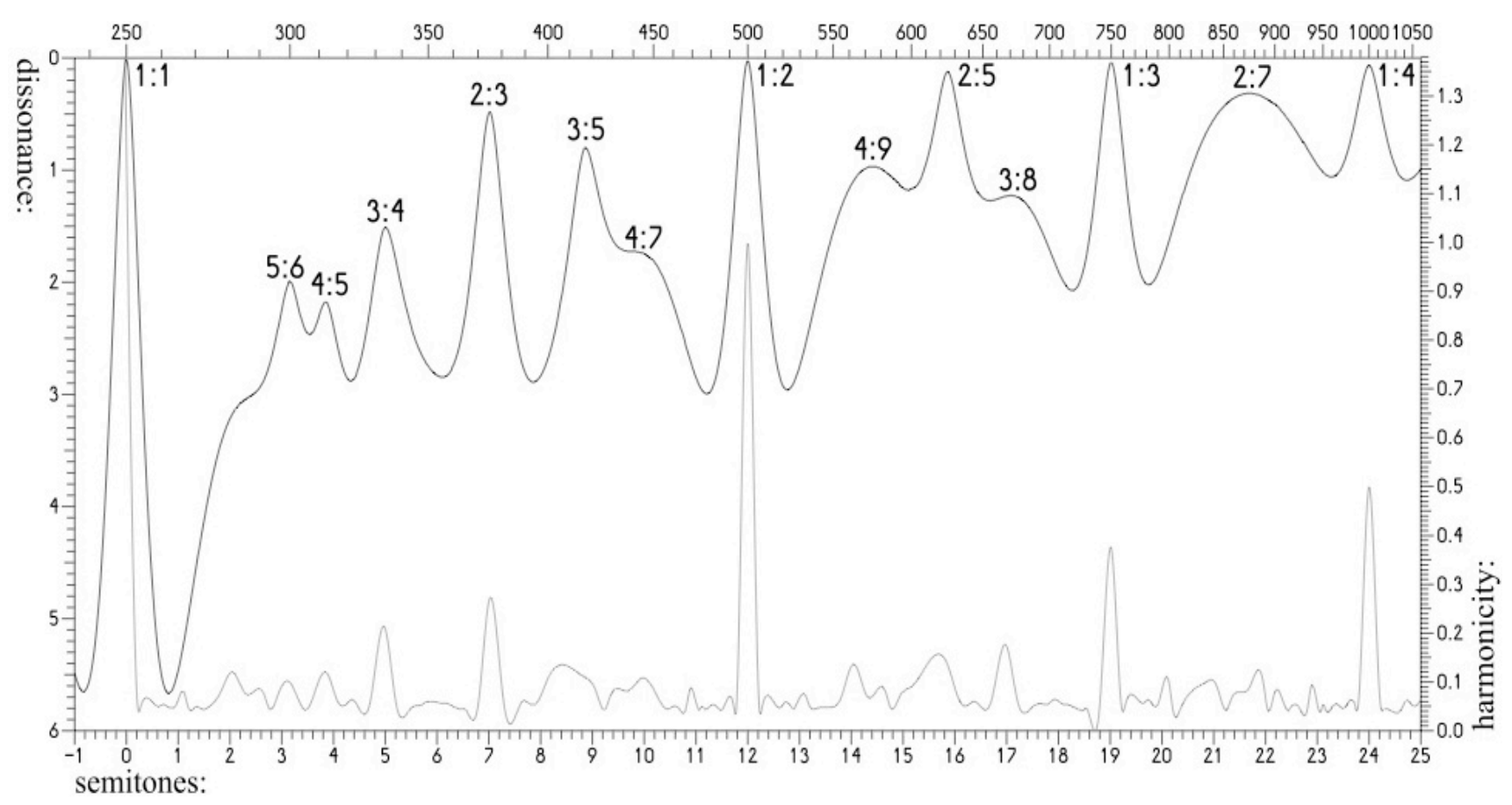

Figura 13 - modelo de Aspereza na linha superior e Harmonicidade de Barlow (2008) na linha inferior.

O gráfico da figura 13 compara o resultado do modelo de Harmonicidade com o modelo de Aspereza de Barlow (que equivale aos resultados originais de Plomp e Levelt da figura 10). O som analisado é o mesmo que Plomp e Levelt aplicaram para obter a figura 10. O gráfico também parte de $250 \mathrm{~Hz}$, mas segue por duas oitavas acima mais um semitom. Por fim, também como na figura 10, o eixo vertical representa a consonância de baixo para cima, e a dissonância de cima para baixo em uma mesma escala entre 0 e 6.

A linha superior da figura 13 é a da Aspereza e podemos conferir como se assemelha bastante ao desenho da Figura 10. A linha de baixo representa a medida de Harmonicidade, de baixo para cima, em uma escala de 0 a 1.4. Vemos que esse desenho de Harmonicidade pende mais para a Curva de Fusão Tonal de Stumpf (1890), apresentada na Figura 6. 


\subsubsection{Entropia Harmônica}

O conceito de "Entropia Harmônica Relativa", de Paul Elrich (1997), possui características similares com o modelo de Harmonicidade de Barlow (1987). Trata-se de um conceito abstrato e matemático para dar conta de uma dimensão perceptiva. Neste caso, Elrich a relaciona explicitamente o conceito de Altura Virtual e Tonalness, porém como uma grandeza oposta. A medida se baseia em teoria da informação, um ramo da probabilidade e estatística na matemática, e é dada por uma Sequência de Farey para $n$ números e seus mediantes.

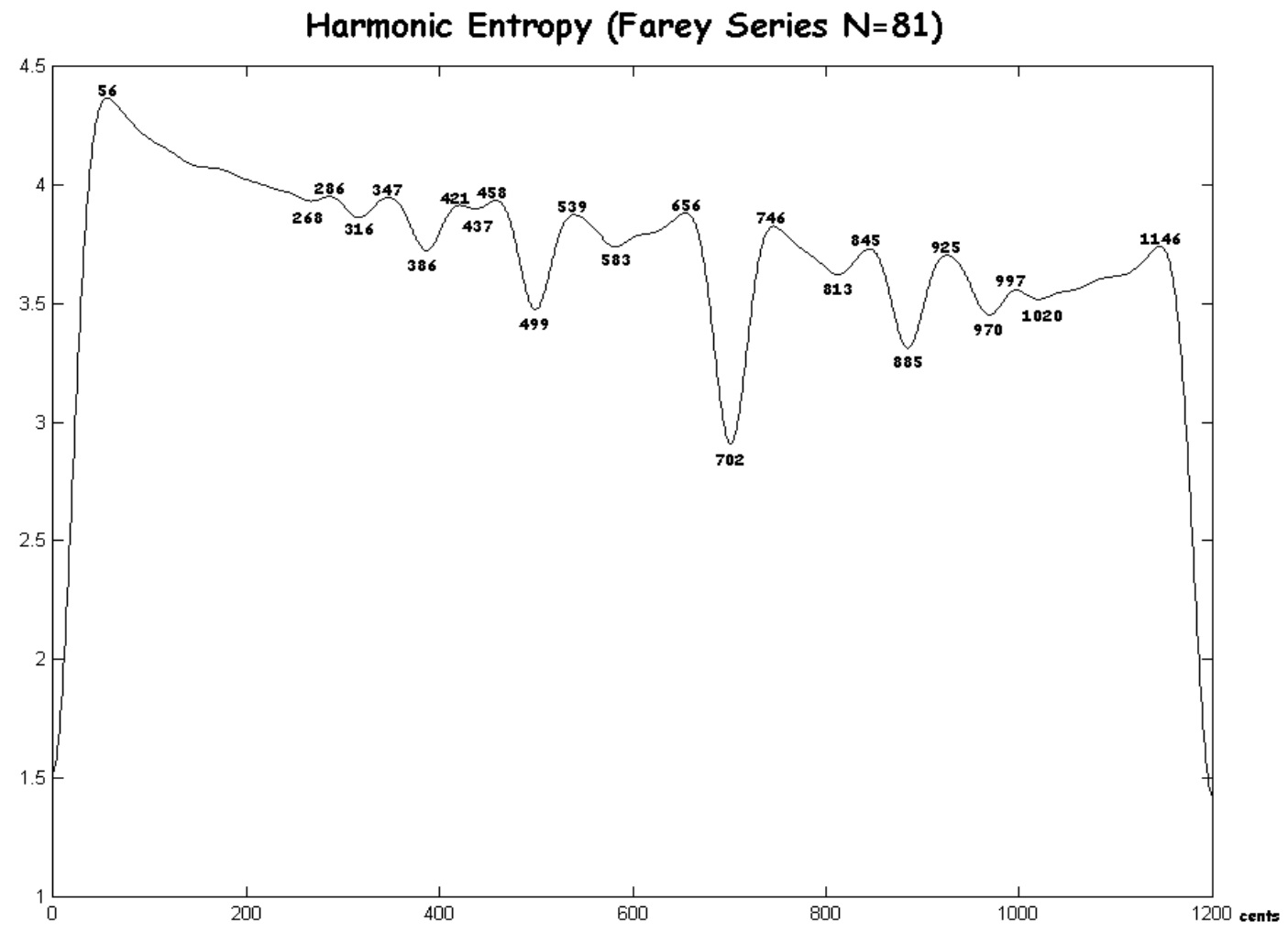

Figura 14 - Entropia Harmônica de Paul Elrich (1997)

Em termos práticos, a função de Entropia Harmônica dá valores mínimos para razões de números inteiros pequenos. Ou seja, é também uma expansão do conceito pitagórico, assim como a função de Harmonicidade de Barlow (1987). Não implementamos esse conceito na pesquisa, mas achamos oportuno mencioná-lo na discussão.

A figura 14 nos dá o resultado para uma sequência de Farey com $n=81$ e traz, no eixo horizontal, os intervalos em cents e, no eixo vertical, a Entropia Harmônica 
como uma medida contrária de Tonalness e a favor de uma percepção de Dissonância. O que é interessante nesse trabalho é que as Curvas geradas se assemelham com Curvas de Aspereza dadas pelos modelos implementados.

Se, por um lado, os resultados do modelo de Elrich são diferentes do modelo de Tonalness extraído de Parncutt (1989), há a semelhança entre os resultados da Entropia Harmônica e os da Aspereza. Essa similaridade traz resultados análogos à Aspereza que são desnecessários, uma vez que já há discrepâncias suficientes nos modelos de Aspereza existentes a serem discutidas neste texto. 


\section{Capítulo 6) - Considerações Finais}

Apresentamos, no início desta primeira parte, a Psicoacústica, dentre outras áreas do conhecimento, como uma área de pesquisa voltada a uma base sensorial da Música. A Psicoacústica se restringe a um nível mais baixo de percepção e tem produzido muitos dados de pesquisa sobre a percepção de atributos perceptivos. Esse tipo de abordagem nos interessa por nos dar a possibilidade de modelar e implementar tais modelos em um computador, em que buscamos aplicações criativas em tempo real para composição e improvisação.

Justamente por se restringir a uma objetividade perceptiva, a Psicoacústica nos dá uma ferramenta concreta de manipulação sonora. Atualmente, uma prova eficaz do impacto da pesquisa nessa área faz parte do nosso cotidiano; a compressão de dados no formato MP3 e afins. Algumas aplicações criativas igualmente eficazes e objetivas já existem nessa área, como será exposto no início da próxima parte. Um dos objetivos desta pesquisa é buscar novos horizontes nesse sentido. Estamos interessados na percepção de dissonância, que é um fenômeno multidimensional, complexo, cuja abrangência foge dos limites de competência da Psicoacústica. Essa problemática também fará parte de uma discussão final. A princípio, apresentamos aqui noções distintas de Dissonância baseadas no trabalho de Tenney (1988) e buscamos, na literatura, os atributos psicoacústicos ligados à percepção de dissonância. Encontramos no trabalho de Terhardt (1984) um quadro completo de atributos. Expomos o conceito de cada atributo em detalhes e, no capítulo anterior, os respectivos modelos psicoacústicos.

O modelo de Brilho é o mais simples e tem sido considerado e aplicado como um Descritor de Áudio. Apontamos como o modelo de Brilho não gera resultados que dizem respeito a relações harmônicas e tem sido desconsiderado em um contexto musical. O Brilho faz parte dos Descritores de Áudio, que têm sido aplicados em pesquisa na área de Music Information Retrieval e em aplicações criativas interessantes em tempo real, como demonstraremos na próxima parte.

Vimos aqui algumas diferentes possibilidades e parâmetros na modelagem de Aspereza. Continuaremos a tratar desta questão a seguir, após apresentarmos o objeto de Pd desenvolvido, com suas possibilidades de parametrização. Usamos essa ferramenta também para comparar resultados e extrair mais considerações na parte 
final.

A Aspereza possui um papel de destaque nesta pesquisa por ser o primeiro elemento apresentado e investigado por Helmholtz (1877) e foi considerada por muito tempo o único atributo psicoacústico da Dissonância Sensorial. Terhardt expande a coleção de atributos psicoacústicos e cria um novo grupo além da Dissonância Sensorial, o de Harmonia. Porém, além do Brilho, Terhardt contribui de fato com a inclusão de atributos baseados em sua teoria de Altura Virtual, sendo este o elemento chave que se desdobra no conceito de Tonalness, Fundamental do Acorde e Comonalidade de Altura.

Em suma, podemos nos valer do conceito de Altura Virtual como um atributo relacionado à percepção de Dissonância. Uma implicação clara da adoção de teoria de Altura Virtual é que a percepção de Altura em si é um fator importante em jogo. Com essa perspectiva, o Tonalness é a Clareza de Percepção de Altura, e a relação com percepção de Altura aqui é trivial. A Fundamental do Acorde também se relaciona com a percepção de Altura, pois implica relações harmônicas entre alturas claras, que remetem a um baixo fundamental em comum pelo fato de as relações harmônicas serem as mesmas de componentes espectrais de um tom com alto Tonalness. De fato, quanto maior o Tonalness de uma sonoridade, maior é a Saliência de Tom como a Fundamental de um Acorde. Por fim, a Comonalidade de Altura é nada menos que uma medida de comparação que busca percepção de alturas em comum.

Então, por um lado, temos a Aspereza, que é uma dimensão que não lida diretamente com a percepção de Altura e apenas diz respeito à interferência de parciais de uma sonoridade em uma mesma banda crítica. Por outro lado, temos alguns desdobramentos em relação à Percepção de Altura. Temos aqui duas dimensões principais que geram Curvas de Dissonância, como veremos primeiramente na próxima parte desta tese. As Curvas de Dissonância são ferramentas de análise importantes e relevantes na pesquisa e remetem também a um teste perceptivo desenvolvido e apresentado na parte final.

Se temos algumas problemáticas e discrepâncias na modelagem de Aspereza, o mesmo não ocorre com o modelo de Altura Virtual e seus desdobramentos. Isso porque temos principalmente o trabalho de Terhardt como a principal fonte, e poucas revisões foram feitas. Mas também, se comparada com a Aspereza, a teoria de Altura Virtual de Terhardt é relativamente recente.

No entanto, buscamos outros possíveis elementos que pudessem aderir ao 
quadro de atributos perceptivos de Dissonância e, assim, abordamos também o conceito de Fusão Tonal. Apesar de o encontrarmos na literatura como um conceito distinto de percepção de Altura - ou, mais especificamente, da teoria de Altura Virtual - entendemos que se trata de um conceito paralelo, pois está igualmente relacionado com relações harmônicas.

A Fusão Tonal depende de relações harmônicas de tons musicais a coloca em direta relação com a "Harmonicidade" ou periodicidade, como descrito no trabalho de Schneider e Frieler (2009). Estes autores trazem uma interessante revisão de modelos auditivos neurais e uma aplicação nos conceitos de consonância por esse viés da neurociência, colocando a Fusão Tonal em uma relação com uma capacidade fisioneurológica de percepção de periodicidade, assim como o fundamento da Altura Virtual.

Tons complexos que evocam uma única sensação de Altura possuem componentes espectrais que se fundem. Um acorde que possui uma fundamental fácil de identificar possui um alto Tonalness, contribuindo para a percepção de consonância e também se relaciona com uma maior Fusão Tonal. Por fim, da mesma maneira que a quinta e a oitava possuem uma maior Afinidade e Comonalidade de Altura, estes são intervalos que promovem mais Fusão Tonal.

Se é o caso de não podermos inserir, pela falta de estudos, um modelo próprio de Fusão Tonal no quadro, isso não nos impede de entendermos, pelas características semelhantes levantadas, que o conceito de Fusão Tonal deve ser relacionado à percepção de Altura, em uma exposição sobre conceitos e modelos de atributos perceptivos da Dissonância.

Se, por um lado, foi possível dar conta de uma revisão da literatura em psicoacústica, nos deparamos com um cenário mais turbulento e complicado ao considerarmos pesquisas e modelos na área de cognição e neurociência. Seria contraproducente revisar esse conhecimento, porque muito pouco ainda pode ser extraído e implementado num sistema computacional em tempo real.

Como o objetivo final da pesquisa é o desenvolvimento de aplicações em tempo real, nos atemos a esse recorte para dar sequência ao plano de trabalho. Entretanto, algumas considerações a respeito de avanços nessa área têm sido trazidas para a discussão e também se encontram nas considerações na parte final desta tese.

Uma relação com trabalhos em neurociência é encontrada em um modelo análogo ao de Altura Virtual, proposto no trabalho de Meddis e Hewitt (1991). Esse 
estudo se baseia em um modelo auditivo periférico nervoso e em uma abordagem de análise temporal, medindo a resposta do sistema nervoso auditivo em relação à periodicidade. Os autores comparam seu modelo com outras teorias de percepção de Altura. Todavia, se temos aqui uma abordagem paralela à percepção de Altura na área de cognição musical, não temos uma aplicação musical e a formalização de um modelo.

A revisão teórica desta pesquisa nos evidencia que a maior questão não é encontrar teorias paralelas e modelos diversos, mas sim encontrar e comparar estudos perceptivos de resposta para contextos explicitamente musicais. São novos testes com essa abordagem que nos levarão a novos modelos mais aprimorados.

Como apontamos aqui, ainda não há resultados claros na área de Psicoacústica e Cognição a respeito de como essas duas dimensões mais importantes da Dissonância - a Aspereza e a Percepção de Altura - se relacionam em um contexto musical para contabilizar uma medida de Dissonância. Retomaremos essa questão na parte final deste trabalho, onde também discorremos sobre um teste desenvolvido durante a pesquisa.

No sentido contrário de uma cognição musical, a "Harmonicidade" também é um termo e atributo comum em Descritores de Áudio. Nesse caso, o conceito é mais direto e objetivo, mais simplificado que o conceito de Tonalness ou Altura Virtual, que possuem uma qualidade de natureza perceptiva.

Aliás, há alguns conceitos diferentes que carregam o termo Harmonicidade. Por exemplo, no padrão MPEG-7, temos a harmonicidade do sinal de áudio com um descritor básico do sinal, mas também descritores espectrais como o Centroide Espectral Harmônico, dentre outros (Mitrovic et al 2010).

De um modo expandido, temos uma classe de descritores harmônicos que incluem descritores diversos como tristimulus, razão entre harmônicos pares e ímpares e até mesmo inarmonicidade (desvio de um modelo harmônico) (Peeters, 2003). Alguns desses descritores, assim como o modelo de Brilho, já foram implementados em Pure Data em bibliotecas de Descritores de Áudio, referidas na próxima parte.

Mais ainda, fora do universo de pesquisas em Descritores de Áudio, modelos psicoacústicos e cognição musical, podemos incluir na revisão teórica conceitos e parâmetros arbitrários, empíricos, desenvolvidos por músicos em trabalhos próprios para aplicações musicais. Esse é o caso do modelo de Entropia Harmônica de Elrich (1997) e o de Harmonicidade de Barlow (1987). 
Uma importante referência em nossa pesquisa no modelo de Aspereza é o trabalho de Clarence Barlow, que considerou fatores que não encontramos em outros modelos, como o efeito de mascaramento e a contabilização de energia dos parciais em escalas de intensidade psicoacústica.

Apesar de um bom rigor em incluir dados perceptivos científicos na elaboração do modelo, em um passo final, o modelo arbitrariamente extrai uma média quadrática das amplitudes como uma forma de redimensionar o valor de Aspereza de acordo com as amplitudes.

Por isso, consideramos revisar esse modelo e incluir o método de Vassilakis (2001). Veremos, na parte final, uma discussão entre a adoção desses diferentes parâmetros, em que levantaremos a questão de um confronto entre uma certa arbitrariedade empírica e dados experimentais. 


\section{PARTE II - Desenvolvimento de Ferramentas Criativas para Eletrônica ao Vivo}

\section{Introdução:}

Grande parte do texto desta segunda parte discorre sobre as ferramentas desenvolvidas durante a pesquisa (capítulos 8 a 11) que serviram de laboratório para a aplicação criativa dos atributos psicoacústicos em tempo real. A maior contribuição e resultado da pesquisa se encontram nesta segunda parte. Em especial, o capítulo 10 traz módulos desenvolvidos na pesquisa em forma de patches de Pure Data e o capítulo 11 traz um patch de Pd como um sistema que engloba elementos desses módulos.

No capítulo 7, iniciaremos um apanhado geral sobre aplicações criativas relativas à psicoacústica. $\mathrm{O}$ capítulo 8 foca em análise espectral e extração de componentes espectrais, um estágio necessário, pois é com esse tipo de análise que alimentamos os objetos implementados na pesquisa.

O capítulo 9, por sua vez, informa os detalhes da implementação dos atributos apresentados na primeira parte em forma de objetos de Pure Data. Mais informações e detalhes teóricos complementares também se encontram presentes nessa exposição. Claramente, esses elementos são os pilares principais das ferramentas criativas desenvolvidas na pesquisa, em que sua aplicação criativa se torna a questão mais importante, a ser concluída também na discussão final desta tese. Já o capítulo 12 encerra essa exposição com algumas considerações finais. 


\section{Capítulo 7) Estado da Arte de Aplicações Criativas}

Não há muitos exemplos de aplicações criativas baseadas nos modelos psicoacústicos de Dissonância, ou ainda de psicoacústica em geral. Isso se explica por haver um distanciamento entre a área de pesquisa psicoacústica e a criação musical, tornando a aplicação desta teoria em música ainda muito incipiente. $\mathrm{O}$ estudo aprofundado de Psicoacústica, aliás, não faz parte da grade de estudo comum de um músico ou compositor.

Outra questão é que a teoria psicoacústica tem muito a investigar ainda sobre o estudo da percepção de dissonância. Esse problema já foi evidenciado na revisão teórica da primeira parte, e retomaremos esta discussão em uma revisão crítica na parte final desta tese.

O maior potencial de aplicação desses modelos está em medir a dissonância de intervalos musicais, analisar estruturas harmônicas de acordes e progressões de acordes, algo que já tem sido tratado pela teoria musical tradicional sem a necessidade de embasamento teórico psicoacústico. Entretanto, este embasamento e a implementação de modelos em tempo real abrem portas para explorarmos novas técnicas.

Destacam-se, nesse sentido, as técnicas de manipulação de Sistemas de Afinação como as de Sethares (1999), em que uma relação entre espectro sonoro e afinação nos permite ajustar intervalos musicais ou mesmo espectros sonoros para que promovam mais ou menos dissonância. No geral, as ferramentas desenvolvidas durante a pesquisa visam explorar esse terreno em tempo real, forma que ainda não foi devidamente explorada. Na seção 7.1 introduzimos esse tipo de aplicação, que será retomada nos exemplos desenvolvidos durante a pesquisa.

Dos poucos compositores que buscaram nos modelos psicoacústicos uma nova fonte de recursos, destacamos, na seção 7.2, o trabalho de Clarence Barlow e Sean Ferguson. Ambos, porém, trabalharam com sistemas de Composição Assistida por Computador, e não com ferramentas em tempo real para Eletrônica ao Vivo.

Por fim, faremos um paralelo com a pesquisa e aplicações criativas em Descritores de Áudio. Esses esforços têm produzido mais exemplos criativos em eletrônica ao vivo e este trabalho pode se configurar como uma expansão dessas técnicas e recursos. 


\section{1 - Aplicação em Afinação e Escalas Musicais}

A grande aplicação e implicação de medidas de dissonância é a possibilidade de analisar díades (intervalos musicais) e acordes. Uma variação desse processo consiste em explorar afinações alternativas, em que comparamos então as medidas para diferentes escalas e sistemas de afinação, técnica que Barlow (1980) também incorporou em seu processo.

Um método possível de analisar sistemas de afinação é por meio de análises de Curvas de Dissonância, onde conseguimos encontrar intervalos mais consonantes de acordo com um espectro sonoro e, por conseguinte, definir um sistema de afinação mais adequado. Pelo mesmo processo, também podemos encontrar os intervalos mais dissonantes, e gerar uma escala com esses pontos mínimos e máximos de consonância/dissonância (Porres 2007). A partir desses dados, podemos ter um corretor de Alturas (Pitch Shifter) para mudar a afinação em tempo real de acordo com a afinação desejada.

Essa relação entre escala e espectro sonoro nos leva a outra técnica possível, que consiste em caminhar na direção oposta. Partimos assim de uma afinação qualquer e manipulamos um espectro sonoro para que ele promova mais consonância com essa afinação de entrada. Essa técnica se chama Mapeamento Espectral (Sethares 1999) e também é possível realizá-la em tempo real.

Sethares é o pioneiro a desenvolver ferramentas em tempo real, tanto na geração de Curvas de Dissonância (1999), quanto na possibilidade de mapeamento espectral - sendo essa desenvolvida mais recentemente com a colaboração de outros pesquisadores (Sethares et al 2009). Em nossa pesquisa, desenvolvemos ferramentas similares, como as apresentadas nos capítulos seguintes. Faremos uma comparação e discussão com o trabalho de Sethares et al. (2009) nas considerações finais desta segunda parte.

Esses autores também criaram o conceito de sintetizadores capazes de manipulações tonais dinâmicas, e alguns instrumentos virtuais foram elaborados nesse sentido. Para isso, um controlador especial para afinações alternativas permite que diversas afinações sejam acessadas por uma mesma interface, e a síntese acompanha a mudança de afinação por meio de um mapeamento espectral ${ }^{17}$.

\footnotetext{
17 Os objetos e sintetizadores virtuais foram implementados em java e MAX/MSP e encontram-se disponíveis na internet em: <http://www.dynamictonality.com/>.
} 


\section{2 - Exemplos de Trabalhos em Composição Assistida por Computador}

O termo Composição Assistida por Computador (ou a abreviação CAC) Computer Aided Composition, em inglês - possui um paradigma de adoção do computador para realizar cálculos complexos como assistência ao processo de composição. O compositor, então, usa essa ferramenta como forma de gerar e analisar material que pode ser concreto ou abstrato (notas em uma partitura).

Esse paradigma não se aplica à eletrônica ao vivo, que envolve um processo de manipulação sonora em tempo real. Em outras palavras, o paradigma de eletrônica ao vivo envolve processos de manipulação sonora e interação em tempo real, enquanto a CAC pode ser empregada como forma de compor música instrumental em tempo diferido.

Programas de computador dedicados ao paradigma de CAC possuem uma estrutura diferente de sistemas de eletrônica ao vivo, como MAX/MSP e Pure Data, mas também se configuram como sistemas de programação. Das plataformas mais importantes de CAC, destacamos os ambientes de programação visual Open Music ${ }^{18}$ e PWGL $^{19}$, ambos distribuídos gratuitamente.

A diferença estrutural é que esses programas não visam uma manipulação sonora em tempo real. Em todo caso, nada impede que ambientes de programação gráfica como MAX/MSP e Pd também possam conter objetos com as mesmas funcionalidades. A ideia é, então, que não há uma inevitável oposição entre esses sistemas - sendo assim possível uma relação entre esses paradigmas.

A CAC surge antes dos sistemas interativos em tempo real. O motivo é trivial, pois a capacidade computacional não permitia cálculos rápidos o suficiente para operações em tempo real. Porém, com o avanço de processamento computacional, os sistemas de CAC atualmente gozam de CPUs de alta velocidade capazes de processar operações diversas em "tempo real”.

Por outro lado, em sistemas de eletrônica ao vivo, é comum que alguns processos não sejam rápidos o suficiente e gerem uma certa latência, ou necessitem de uma pequena janela de tempo a ser considerada em performance. No caso das ferramentas desenvolvidas nesta pesquisa, alguns processos se enquadram nessa forma, como a geração de Curvas de Dissonância. Ou seja, nada impede que possamos implementar operações que ainda não ocorrem em tempo real em sistemas de 
eletrônica ao vivo, e isso promove mais uma ponte entre esses paradigmas.

O fato é que sistemas em tempo real só puderam se desenvolver há relativamente pouco tempo, e há uma constante evolução dessas ferramentas em acompanhamento das novas capacidades de processamento. Assim, estamos sempre explorando os recursos até o seu limite. Esse é outro fator que torna o objeto desta pesquisa incipiente, pois a possibilidade de implementação de tais recursos em sistemas de tempo real é recente. Não obstante, temos exemplos de uso dessa teoria em sistemas de CAC, em que destacamos aqui o trabalho de Ferguson (2000) e Barlow (1980).

\subsubsection{Sistema Apprentice, de Sean Ferguson}

Sean Ferguson, em sua tese de doutoramento (2000), trabalhou na composição de um concerto para piano em que adotou o modelo de Comonalidade de Altura e Aspereza - dentre outros conceitos que não fazem parte do nosso quadro de atributos, como a teoria de contorno rítmico e melódico. O autor implementou os modelos psicoacústicos em um sistema de CAC chamado Apprentice (Aprendiz), desenvolvido em Open Music.

O modelo de Aspereza adotado foi o de Hutchinson e Knopoff (1978), levando em conta a revisão e implementação de Parncutt em um código em C (1993). O modelo de Comonalidade adotado corresponde ao trabalho de Parncutt (1989), que também adotamos como base para a implementação do objeto em Pure Data. Sean Ferguson não se valeu do conceito de Tonalness nem da Fundamental do Acorde em seu processo composicional, tampouco do Brilho.

Nenhuma alteração microtonal ou adoção de afinações alternativas foi considerada, portanto o modelo de Comonalidade de Altura foi adotado por Ferguson em seu modo original, em uma resolução de alturas que corresponde a 10 oitavas no sistema temperado. Um banco de dados com análises espectrais de instrumentos musicais foi previamente armazenado para que a entrada do programa pudesse receber e gerar dados apenas com uma entrada abstrata de informação (notas musicais em uma partitura).

A teoria de contorno adotada por Ferguson possui um papel relevante como elemento unificador em seu método de composição, responsável por determinar muitos aspectos estruturais da peça. Portanto, os atributos da dissonância não formam o único pilar da obra. Levantamos aqui uma consideração que permeará discussões finais, que 
é a questão de quanto, ou como, apenas um modelo de dissonância pode sustentar uma poética composicional. Ferguson, sobre sua visão, afirma o seguinte:

Em anos recentes, um dos meus principais objetivos tem sido aumentar o potencial expressivo de minha música ao fortalecer a conexão entre minhas intenções criativas, minhas técnicas composicionais, e as reações do ouvinte. Eu quero estar mais confiante que as respostas musicais básicas que eu quero evocar ocorrerão. Eu creio que melhorar essa conexão ajudará que minhas ideias composicionais sejam comunicadas mais claramente e efetivamente. De modo a realizar tal objetivo, é preciso que se entenda de antemão os modos fundamentais com que as pessoas percebem seus ambientes auditivos, e então encontrar formas de integrar esse entendimento em processos composicionais (Ferguson, 2000 p. 1).

Neste trecho, Ferguson entende que há um grande desafio nesse tipo de abordagem, e que ainda estamos dando os primeiros passos nessa jornada e pesquisa. Seu concerto foi, de fato, a primeira peça que adotou esses modelos em particular. Logo, o autor também reconhece que refinamentos desse tipo de técnica devem ser desenvolvidos a partir de mais experiência composicional e do avanço das próprias teorias e modelos psicoacústicos. Em suma, na visão desse autor, trata-se de uma abordagem e pesquisa ainda em aberto, incipiente, e com espaço para ser devidamente explorada, sendo a sua contribuição modesta, porém pioneira.

Em uma segunda publicação (Ferguson e Parncutt 2004), Ferguson discorre sobre as mesmas questões, nos dando como exemplo uma segunda peça orquestral composta por ele. Não obstante, nenhuma nova consideração surge a respeito das técnicas e poéticas composicionais.

No que diz respeito aos atributos de Dissonância, o processo de Ferguson consistiu em medir a Aspereza de acordes e organizá-los em uma progressão harmônica de acordo com uma relação crescente ou decrescente dessas medidas (ditas medidas de Dissonância, reforçando a relação sinonímica apontada entre Aspereza e Dissonância). Já o modelo de Comonalidade de Altura foi adotado para medir a semelhança entre acordes sucessivos, mas também em relação a uma sonoridade de referência em um plano de fundo gerado pela orquestra. São esses elementos e o controle desses parâmetros que definem a linguagem e estrutura harmônica da peça. As figuras a seguir trazem exemplos gerados pelo sistema Apprentice. Na Figura 15, temos medidas de Aspereza de uma série de tetracordes. Já na Figura 16, temos a medida de Comonalidade de Altura entre acordes sucessivos. 

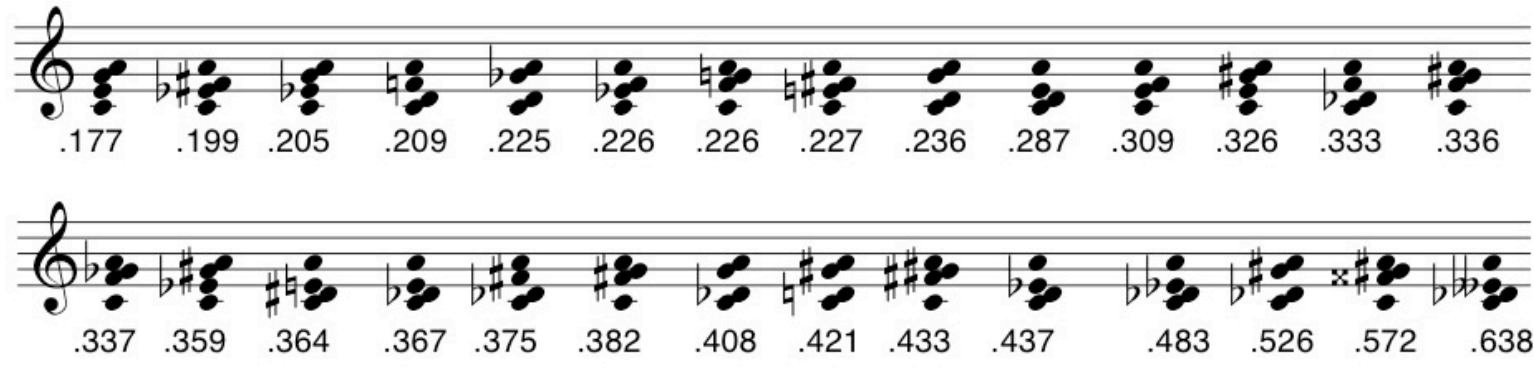

Figura 15 - Medidas de Aspereza para diferentes tetracordes.

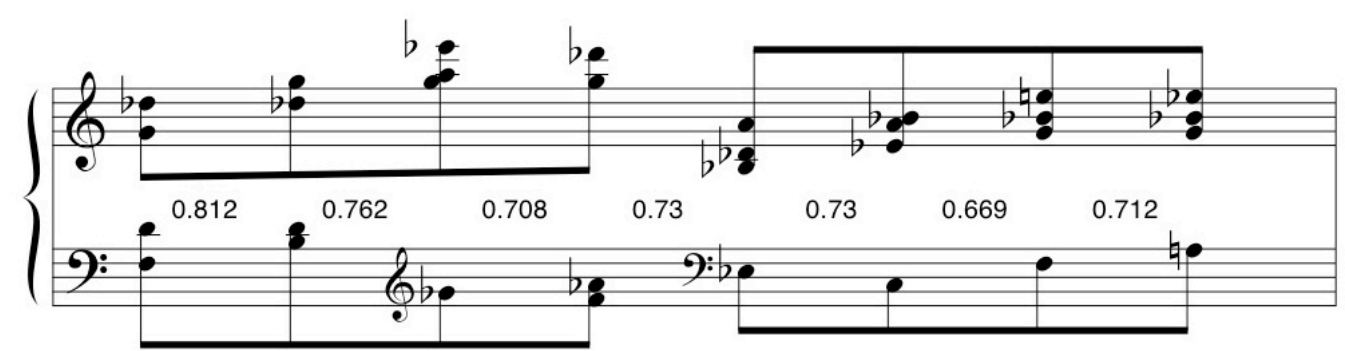

(High overall successive pitch commonality)

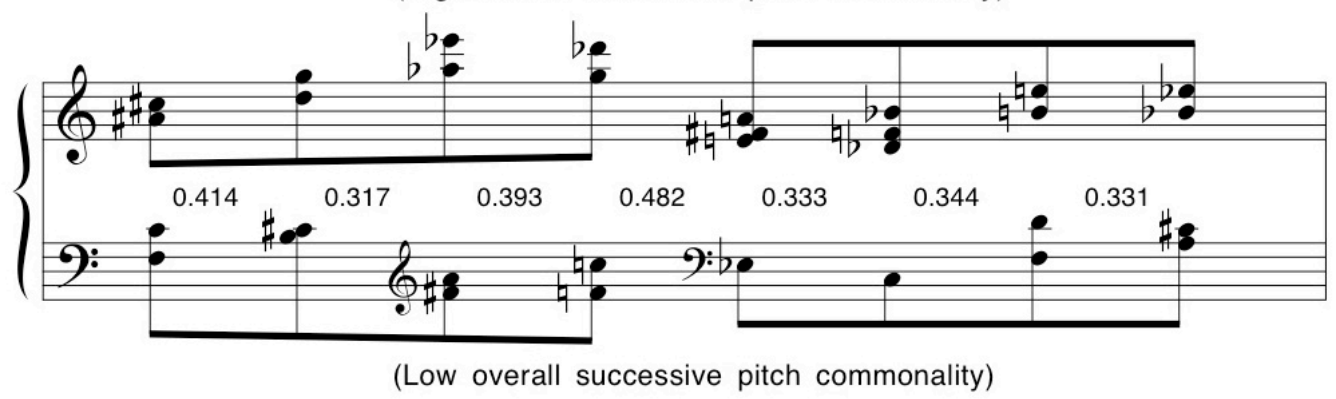

Figura 16 - Comonalidade de Altura entre sonoridades sucessivas.

A figura 17 nos traz um exemplo de uma análise do contorno de dissonância dos acordes de piano do início da peça, nos quais vemos que o compositor teve a intenção de escrever uma passagem que apresentasse essa curva de resposta para a sensação de Dissonância (dada somente pela Aspereza).

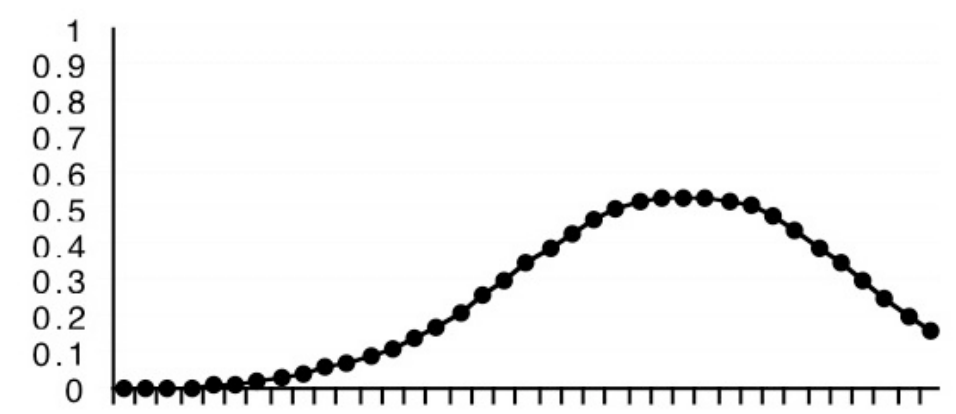

Figura 17 - contorno de dissonância (Aspereza) da seção de abertura do concerto 
Neste concerto para piano, Ferguson também define regiões harmônicas ao escolher consistentemente acordes que possuem uma alta Comonalidade com uma sonoridade de referência. Essa sonoridade pode estar de fato presente na peça, ou ser apenas sugerida, implícita. No caso da sonoridade estar ausente, ela, normalmente, fora previamente enfatizada. Na figura a seguir, temos a sonoridade de referência principal adotada na obra.

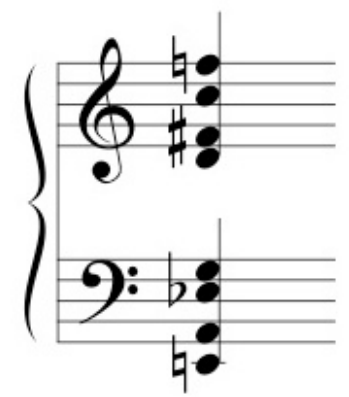

Figura 18 - Sonoridade Referencial primária do Concerto para Piano de Ferguson

O acorde da Figura 18 é inversamente simétrico, mas não há simetria em sua transposição (há 12 possíveis transposições para ele). Ferguson também criou uma progressão harmônica de fundo que varia entre a sonoridade de referência primária à sua transposição que promova a menor comonalidade com a original.

\subsubsection{Sistema AUTOBUSK \& Dissonometer, de Clarence Barlow}

Como no trabalho de Ferguson, Clarence Barlow adota um sistema computacional para fins de composição instrumental. Seu primeiro programa de composição algorítmica foi criado no final da década de 1970 (em FORTRAN) para ser aplicado na composição da peça para piano Çoğluotobüsişletmesi (1975-79), em que sua teoria sobre tonalidade e métrica (Barlow 1980) foi primeiramente explorada.

O sistema se desenvolveu e é conhecido atualmente como AUTOBUSK. Uma implementação para computador ATARI, da década de 1980, se encontra disponível na internet ${ }^{20}$ e pode ser compilada com emulador de sistema ATARI nos PCs atuais. Essa versão mais recente funciona em tempo real, como um sistema interativo, mas não manipula áudio em tempo real, e sim apenas gera informação MIDI.

A poética de Barlow difere da de Sean Ferguson por causa das suas influências de música estocástica, técnica composicional na qual começou a trabalhar em 1971

$20 \quad$ Vide; <http://www.musikwissenschaft.uni-mainz.de/Autobusk/>. 
(Kaske 1985) e ainda mantém presente em sua estética e poética. Barlow tem, desde então, empregado frequentemente o computador como meio de gerar as estruturas de suas obras. Portanto, o sistema composicional possui essa diferença conceitual de ser um ambiente generativo e estocástico, enquanto Ferguson buscava uma assistência em seu sistema para gerar material e compor sua obra, sem o mesmo paradigma algorítmico. Apontamos a complexidade do sistema AUTOBUSK e trazemos algumas considerações sobre a aplicação desse sistema e o método composicional em Çoğluotobüsişletmesi.

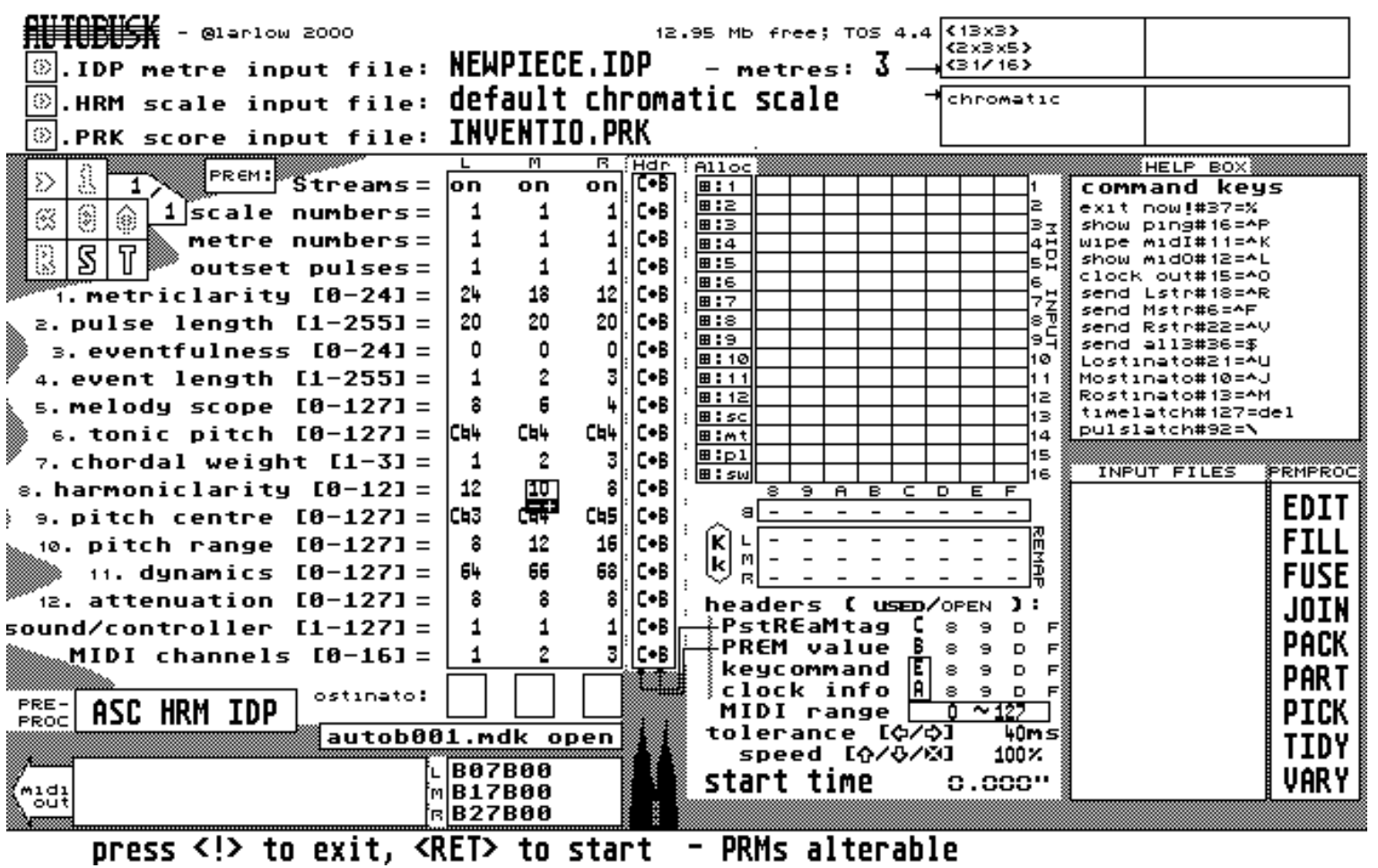

Figura 19 - tela do sistema AUTOBUSK.

O AUTOBUSK recebe uma entrada que determina a geração de música (em formato MIDI) de acordo com os parâmetros dados. O resultado depende do conjunto de vários parâmetros e não é totalmente determinístico, estando sujeito a diversas possibilidades coerentes com as especificações dadas. Além de conceitos psicoacústicos como a Aspereza, o sistema de Barlow se baseia em conceitos próprios. Logo, assim como Ferguson, o compositor não se vale apenas de atributos da dissonância como método de desenvolvimento composicional.

O sistema de Barlow, para essa peça, traz oito parâmetros texturais, que podem ser definidos individualmente por mais de um conceito que, por sua vez, pode consistir 
em um processo com mais de um passo. De modo geral, eles se relacionam com uma teoria rítmica/métrica e tonal/harmônica. Dos oito parâmetros, quatro são ditos "principais", enquadrados em dois grupos: Coesão (métrica e harmônica) e "Suavidade" (rítmica e melódica). Dos parâmetros secundários, temos conceitos como densidade do acorde (número de notas), densidade de pausa, dinâmica e articulação.

Dado essa complexidade, ressaltamos apenas o papel dos atributos relacionados à nossa pesquisa (Aspereza e Harmonicidade). Ateremo-nos, então, aos parâmetros de coesão harmônica e suavidade melódica. Sua teoria de Harmonicidade foi adotada para analisar escalas e afinações alternativas. Barlow calculou um valor geral de Harmonicidade dentre os intervalos (razões) de várias escalas/modos possíveis, considerando alterações em quartos de tom. O parâmetro de coesão harmônica controla a tonalidade da peça, que varia de uma atonalidade ao surgimento de modos e escalas. Já a suavidade melódica diz respeito a saltos intervalares. Um salto mais suave é para tons adjacentes, enquanto uma menor suavidade gera saltos aleatórios e pontilhísticos. Junto a isso, temos a medida de consonância (Aspereza) e Harmonicidade em relação à fundamental do acorde.

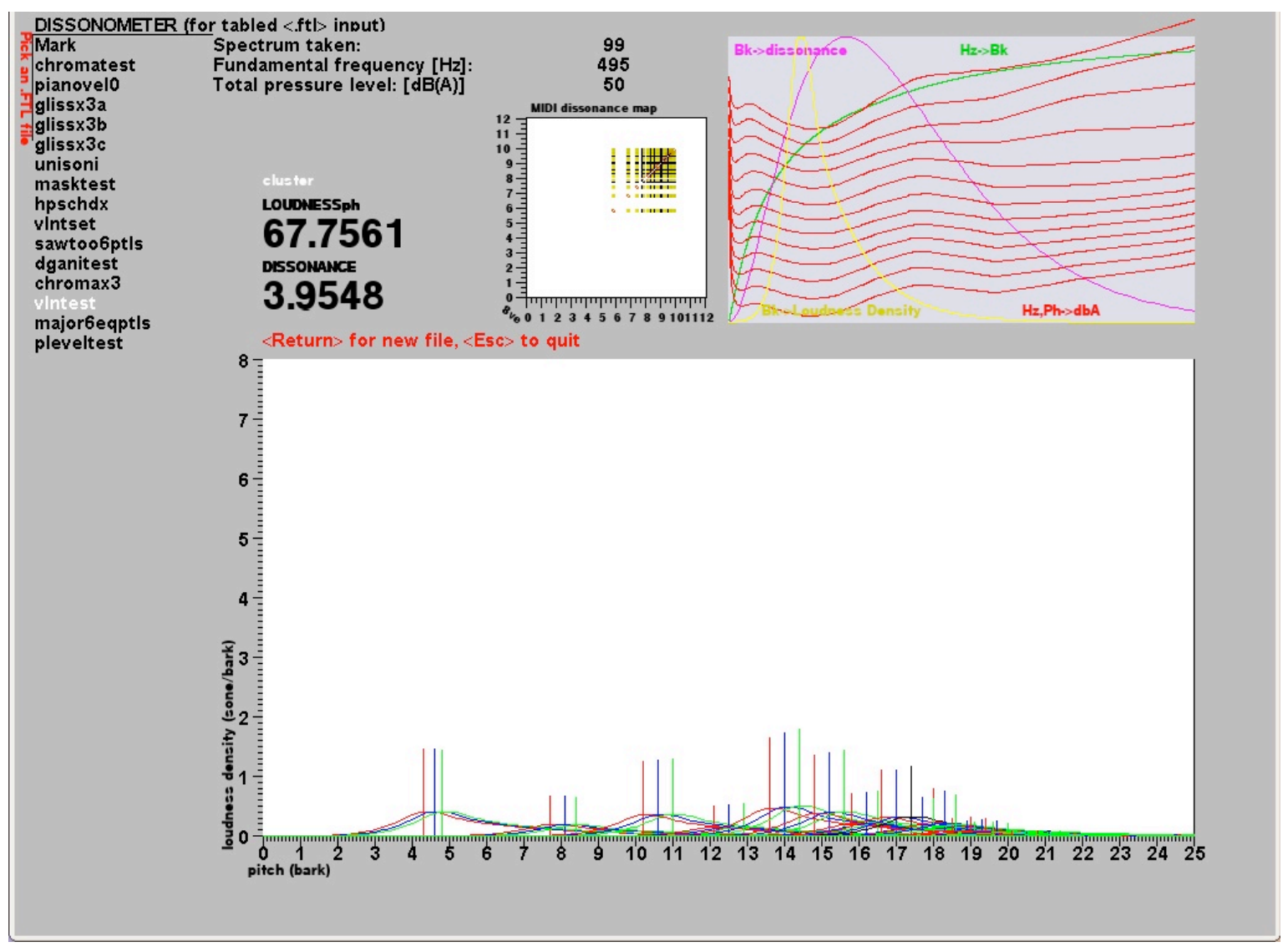

Figura 20 - Tela do programa Dissonometer, de Barlow. 
Dissonometer é outro programa desenvolvido por Barlow que se dedica apenas à medida de Dissonância entre dois espectros sonoros (vide Figura 20). A medida de Dissonância, entretanto, é dada apenas pelo modelo de Aspereza, que é o modelo adotado como base em nossa pesquisa. Com essa ferramenta, é possível fazer o mesmo tipo de ordenação que Sean Ferguson empregou em seu trabalho.

Na Figura 20, o quadro maior representa o espectro sonoro, dado na escala da banda crítica. As curvas no canto superior direito representam as funções psicoacústicas, como a curva de Plomp e Levelt (1965) em roxo claro, as curvas de loudness, em vermelho, a conversão de Hz para a escala da banda crítica (bark), em verde, e uma função de mascaramento segundo Zwicker e Fastl (1999), em amarelo.

\section{3 - Aplicações Criativas com Descritores de Áudio}

Traçamos aqui uma espécie de paralelo com Descritores de Áudio que se mostrou necessária, pois colocaremos os atributos psicoacústicos de dissonância também em um paradigma de descritores. Relembrando que os Descritores de Áudio estão em um nível mais baixo de percepção, os modelos aqui descritos podem ser encarados como Descritores Psicoacústicos, de um nível mais alto, ou ainda "Descritores de Dissonância". Portanto, mesmo que paralelo de certo modo, os programas e aplicações com descritores de Áudio são também referências para esta pesquisa.

Já que a adoção de atributos psicoacústicos (ou de níveis mais altos) em aplicações musicais criativas ainda é uma área muito incipiente, os exemplos com Descritores de Áudio se tornam relevantes e importantes. Os Descritores de Áudio despontam de forma muito mais consolidada em aplicações criativas em tempo real e podem ser encarados como um primeiro passo nessa trilha que estamos traçando.

Quanto às aplicações criativas, em linhas gerais, as informações extraídas por Descritores de Áudio podem ser usadas como dados de controle dos modos mais diversos. Por exemplo, com a detecção de um dado qualquer, como a altura de um som, podemos então usar essa informação para controlar outro parâmetro qualquer, como a intensidade sonora. Esse tipo de procedimento é, na verdade, um processo muito elementar em eletrônica ao vivo, que é um ambiente onde sempre exploramos quaisquer possibilidades de interação. Em todo caso, o interessante é encontrar aplicações mais pertinentes, com um potencial próprio e especial. Estamos lidando 
com informações sonoras bem específicas, que descrevem elementos musicais distintos, em que o reconhecimento e identificação de certas qualidades sonoras pode fornecer novas possibilidades criativas.

Os descritores de áudio aplicados em MIR (Music Information Retrieval) visam extrair informações básicas, a partir das quais podem ser derivados elementos secundários e mais complexos, como detecção de ritmos. Dos elementos fundamentais de um som, entende-se que podem ser descritos por quatro elementos básicos: altura, intensidade, duração e timbre (Peeters 2004). De modo simplificado, uma nota em uma partitura musical também codifica esses quatro elementos.

Dos quatro elementos citados, o timbre é o mais difícil de definir e, por conseguinte, descrever. A definição mais simples de timbre o caracteriza como uma dimensão que permite distinguir sons com uma mesma duração, altura e intensidade. Ou seja, trata-se, na verdade, de uma definição por exclusão, sem uma definição positiva clara, a ponto de um autor como Bregman (1990, p.93) afirmar que o timbre é a "lata de lixo de todas as características que não podem ser rotuladas como altura ou loudness".

Um paralelo entre timbre e Dissonância foi apontado por Vassilakis (2001) que, parodiando Bregman, afirmou que o Dissonância de consonância tem sido a "lata de lixo de julgamentos avaliativos estéticos em música”. Esses exemplos denotam uma pobreza da linguagem em definir e esmiuçar esses conceitos. A pesquisa psicoacústica, assim, contribui para um enriquecimento desses conceitos a partir do mapeamento de parâmetros físicos/psicofísicos que podem ser relacionados à percepção tanto de timbre quanto de Dissonância.

Enquanto a duração, altura e intensidade são qualidades perceptivas mais simples e relacionadas com poucos fatores acústicos, o timbre se caracteriza como dependente de um conjunto maior de fatores, levando em conta diferentes dimensões perceptivas. Como a descrição e detecção de duração, altura e intensidade sonora são processos mais simples e relativamente consolidados, os maiores esforços atuais de pesquisa se concentram em aplicar descritores de áudio na identificação e descrição de timbre.

Quanto aos aplicativos específicos para eletrônica ao vivo, apontamos algumas bibliotecas existentes em Pure Data (há já pelo menos três conjuntos delas). A biblioteca LibXtract, desenvolvida por Jamie Bullock (2007), contém alguns dos atributos pertencentes ao padrão $M P E G-7$ e ao projeto $C U I D A D O$. Essa biblioteca foi 
implementada em Pure Data e em Sonic Visualizer $^{21}$ - um programa de computador especializado em gerar análises de atributos sonoros. Logo, a característica principal dessa biblioteca é de simples e pura descrição de atributos, e não tem função criativa própria.

Já a biblioteca de Monteiro e Manzolli (2010) traz uma boa coleção de descritores de áudio em abstrações de patches de Pd. Esse trabalho busca aplicações em tempo real a partir dos dados extraídos em performance ao vivo, em que a pesquisa analisou parâmetros extraídos do comportamento físico do som para duas funções: segmentação de eventos do sinal de áudio (como notas), ou seja, detecção de início e fim de cada evento, e classificação de alturas de cada segmento. Também foram desenvolvidos alguns experimentos com Mapas de Poincaré para visualização da dinâmica de alguma função (no caso, o fluxo espectral, mas poderia ser outra dependendo da necessidade).

William Brent (2009) desenvolveu uma biblioteca para Pure Data voltada para classificação e análise de timbres e avaliou a eficácia dessas medidas. Ele se vale de alguns poucos descritores, que são na maioria os mesmos descritores de baixo nível da LibXtract. Porém, Brent busca maior objetividade e usabilidade em seus objetos, além de buscar fornecer aplicações criativas baseadas nesses descritores já voltadas para um usuário final, o que resultou em um objeto classificador, o [TimbreID]. Esse trabalho é o que mais se volta a aplicações criativas avançadas, como a Síntese Concatenativa, e será retomado na subseção 7.3.2 deste capítulo. Partimos agora para algumas aplicações específicas dos Descritores de Áudio.

\subsubsection{Identificação de Alturas}

A extração de informação sobre a Altura (Pitch Tracking) é um dos elementos que obtemos com Descritores de Áudio e também uma referência nesta pesquisa, pois, como veremos adiante, trabalhamos com manipulação de intervalos musicais e construção de harmonias, em que o processo de identificação de alturas nos ajuda muito. De fato, um ponto levantado nesta tese é como os modelos de Tonalness e Fundamental do Acorde podem ser considerados descritores de altura mais refinados, assim como os dados do Perfil de Peso de Alturas e Perfil de Saliência de Alturas.

Antes de mais nada, descreveremos a Identificação de Altura como um

$21 \quad$ Disponível em $<$ http://www.sonicvisualiser.org/>. 
processo simples e direto de descrição de áudio, em que modelos visam extrair a fundamental de um tom complexo sem uma preocupação maior na resposta perceptiva. A Identificação de Altura foi responsável por uma das primeiras e mais importantes técnicas em eletrônica ao vivo, o Acompanhamento de Partitura, mencionado a seguir. $\mathrm{Na}$ sequência, traremos uma expansão desse paradigma com outras possibilidades técnicas.

\subsubsection{Acompanhamento de Partitura (Score Following)}

Na década de 1980 do século XX - em uma primeira fase, antes ainda de uma possível análise em tempo real da entrada de sinal sonoro - o processo de Acompanhamento de Partitura (do inglês Score Following) se desenvolveu com o advento do protocolo MIDI. Esse processo é bem trivial, em que um músico toca um instrumento MIDI como um teclado sintetizador e o computador pode facilmente acompanhar a entrada de notas.

Assim que a capacidade computacional permitiu análises em tempo real, uma nova geração de Score Following começou a se desenvolver apenas com a identificação de alturas de uma entrada de áudio. Essa é uma das primeiras e mais importantes técnicas que surgem em Eletrônica ao Vivo e implica um paradigma central, em que o computador pode entender e acompanhar um intérprete que está tocando um instrumento acústico em tempo real.

Esse paradigma ainda é o elemento chave que estamos explorando com a possibilidade de identificação de novos parâmetros além da altura, como trazidos nesta pesquisa. Entretanto, o Score Following manteve-se alheio e ainda se vale, principalmente, de Detecção de Alturas, em que uma representação da partitura é previamente armazenada no computador e um detector de Alturas pode apontar em que lugar na partitura o intérprete estaria tocando.

O paradigma de Score Following é um ótimo exemplo de como podemos identificar um descritor e programar uma reação a ele. Sua aplicação tem sido restrita e limitada, mas possui atualmente um grande potencial de expansão que ainda começa a ser explorado. Este processo pode ser expandido com a detecção de outros elementos, sejam eles descritores de áudio próprios da identificação de timbre, ou ainda atributos psicoacústicos de ordem superior. Ao se abrir para diversos atributos, o Score Following pode ser expandido para uma forma mais geral de "Feature Following". 


\subsubsection{Antescofo (Expansão do Paradigma de Score Following)}

Os avanços em Acompanhamento de Partitura têm envolvido sistemas de reconhecimento de trilos, apogiaturas, nota, e também sistemas de antecipação e detecção de tempo e andamento, como o antescofo $\sim$ - desenvolvido no IRCAM ${ }^{22}$ por Arshia Cont (2008a, 2008b). O trabalho de pesquisa de Cont é em modelagem de Antecipação Musical, implementada no seu software, cujo nome vem de Antecipatory Score Following. O antescofo é um módulo de Score Following para MAX/MSP e Pure Data. Além de ser um módulo com capacidades avançadas de detecção de tempo, o sistema também se constitui como uma linguagem de programação síncrona dedicada à composição musical, que permite uma interação mais flexível com o computador.

Esse trabalho expande o paradigma de Acompanhamento de Partitura e se apresenta como uma ferramenta de interação em computação musical para composição e performance, que tende a evoluir continuamente. Sua estrutura modular permite uma abertura para incluir dados de representação musical definidos pelo usuário. Aqui se inclui perfeitamente a codificação de elementos não convencionais em Score Following, que seriam baseados em detecção de Altura, por exemplo. Tal abertura permite a adoção, para esse fím, de Descritores de Áudio e modelos Psicoacústicos. Em suma, trata-se de um ambiente que se abre a esse conceito de Feature Following.

\subsubsection{Outras Aplicações com Detecção de Alturas}

O Acompanhamento de Partitura também carrega outro paradigma, que é o da própria partitura. Ou seja, da existência de uma obra fechada e uma sequência de eventos pré-determinada. A identificação de alturas, ou outros parâmetros podem ser usados fora desse contexto, como em sistemas abertos de improvisação e performance.

Em paralelo a esses simples processos de identificação e interação, podemos pensar em processos mais sofisticados de manipulação dos dados. No momento em que identifico uma altura, posso buscar em um banco de dados sons com outros timbres que possuam a mesma altura. É possível analisar um trecho gravado e ordenálo em ordem ascendente ou descendente.

Veremos logo mais como esse tipo de processo pode ser interessante no que diz respeito ao reconhecimento de timbre. Veremos também como o objeto [Pitch-

$22 \quad$ Vide $<$ http://www.ircam.fr/>. 
Commonality] desenvolvido nesta pesquisa é capaz de comparar alturas de sons distintos e buscar em um banco de dados sons que possuam uma alta afinidade (como uma nota em relação de oitava ou quinta).

Outro exemplo criativo dessa ordem é um patch de Pure Data desenvolvido por Miller Puckette e apresentado em uma performance com ele (na guitarra) e Rogério Costa (no saxofone alto) na PdCon09 (Terceira Convenção Internacional de Pure Data). Nesse caso, a entrada de áudio de um instrumento foi armazenada em um banco de sons e usada para imitar a linha melódica de outro instrumento em tempo real. Por exemplo, enquanto o sax tocava uma linha melódica, o computador analisava o material pré-gravado da guitarra e alterava a altura das notas para reconstruir a linha melódica. Veremos no capítulo 10 como o sistema desenvolvido nesta pesquisa também é capaz de imitar uma linha melódica de um modo similar. Isso depende, claramente, de módulos de mudança de altura, também apresentados na exposição dos patches desenvolvidos durante esta pesquisa.

\subsubsection{Identificação de Timbres e Reconstrução de Timbres}

Dado a complexidade que envolve a compreensão de percepção de timbre, sua identificação, descrição e modelagem ainda são problemas complicados e não completamente resolvidos. No que diz respeito às aplicações criativas, temos, igualmente, a capacidade de detecção de certas características e a possibilidade de programarmos diferentes formas de interação com essa informação, ou ainda imitar e reconstruir sonoridades com qualidades similares. É aqui onde encontramos o real estado da arte em aplicações de Descritores de Áudio em criação musical.

A biblioteca de William Brent em Pure Data foi testada e otimizada para algumas aplicações como a identificação de vogais e instrumentos de percussão. Mencionamos que esta é uma biblioteca com poucos descritores e isso é um sinal que com apenas alguns descritores já é possível obter bons resultados para certos problemas. Um grande número de descritores não garante uma refinada extração de atributos particulares. A maioria dos descritores é formalizada por análises estatísticas sob o espectro sonoro, e isso gera uma certa redundância ou similaridade, sendo possível encontrar um subconjunto de descritores mais eficientes para certos fins.

Com a capacidade de reconhecer certas qualidades sonoras, podemos organizar sons com características semelhantes, ou mesmo dissimilares. Nesse âmbito, desponta uma técnica que consiste em reconstruir ou imitar um som a partir de outros com 
características similares, conhecida como Síntese Concatenativa. Essa reconstrução se dá a partir de pequenos trechos sonoros, ou "grãos". Isso faz dessa técnica uma extensão de Síntese Granular. A Síntese Concatenativa também é uma das possibilidades fornecidas pela biblioteca de William Brent.

Em MAX/MSP, temos um módulo de Síntese Concatenativa chamado CATART (Diemo et al 2006). Destacamos um trabalho de composição baseado nesse sistema por Bruno Ruviaro (2010). Como o nome do seu texto (no português: "Impropriedade intelectual: empréstimos musicais como manifesto em composições acústicas e eletroacústicas") informa, trata-se de uma poética de gerar novos objetos musicais a partir de material de outros compositores. Apesar de a técnica de Síntese Concatenativa possuir essa aplicação de reconstrução sonora, não é exatamente isso que Ruviaro explora. Esse exemplo ilustra como um trabalho criativo em composição musical pode subverter os princípios e potencialidades de um sistema qualquer, em que o compositor encontra inspiração na técnica para uma poética criativa distinta.

Motivações dessa ordem são mais que bem-vindas em composição musical. Esse é outro fator que, de certa forma, não contribui para a promoção de ferramentas como as desenvolvidas em nossa pesquisa. Afinal, trata-se apenas de uma ferramenta, de um instrumento, e essa questão será retomada na discussão final deste trabalho, frente a exemplos criativos desenvolvidos durante a pesquisa.

Outro exemplo interessante e relacionado à técnica de Síntese Concatenativa e ao trabalho de Bruno Ruviaro é a performance audiovisual $s C r A m B l E d$ ? HaCkZ!, de Sven König ${ }^{23}$. Esse trabalho se vale de um processo de reconstrução de uma entrada de som ao vivo, que é a voz do performer. A sua reconstrução ocorre a partir de um banco de sons de algum famoso clipe musical, cujo vídeo é tocado junto com os respectivos trechos de áudio. Em todo caso, não se trata propriamente de reconstruir uma fala reconhecível, mas sim de um ambiente de controle onde, por meio da voz do performer, é possível gerar loops a partir de ritmos e barulhos vocais como "beatbox" - ao mesmo tempo em que se edita o vídeo ao vivo.

Terminando a exposição de ferramentas relacionadas ao reconhecimento de timbre, trazemos ainda mais um exemplo, para reforçar como esse campo tem sido

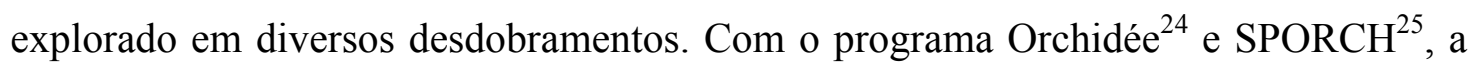

\footnotetext{
Vide $<$ www.popmodernism.org/scrambledhackz/>.

Disponível em $<$ http://repmus.ircam.fr/orchidee $>$.

Disponível em $<\mathrm{http} / / /$ sporch.sourceforge.net/>.
} 
identificação e reconstrução de timbres permite que uma entrada sonora seja reconstruída a partir da combinação de instrumentos orquestrais. Esse processo expande, na realidade, a técnica de reconstrução de timbre para que seja adotada na música instrumental.

\subsubsection{Expansão com "Descritores de Dissonância"}

Enquanto processos de Síntese Concatenativa e similares são comuns e estão em um estágio interessante de desenvolvimentos de pesquisa, processos da mesma ordem com descritores de nível mais alto, como os atributos da dissonância aqui expostos, ainda não foram devidamente explorados, salvo alguns exemplos como os processos de composição assistida por computador de Ferguson (2000) e Barlow (1980). Mas, levando em consideração novas possibilidades em tempo real, ou ferramentas de eletrônica ao vivo como MAX/MSP e Pure Data, podemos somente mencionar uma ferramenta recém-lançada por Sethares et al (2009), que ainda não tem sido devidamente explorada por compositores.

O paralelo com Descritores de Áudio foi apresentado para indicar como as novas ferramentas aqui pesquisadas dialogam com esses esforços. Para tal, encaramos os atributos perceptivos estudados em nossa pesquisa também como "Descritores". No caso, para distingui-los, chamaremos de "Descritores de Dissonância". E, assim, apontaremos algumas considerações sobre como esses atributos psicoacústicos podem se constituir como uma expansão dos processos apresentados.

Por exemplo, da mesma maneira que sons de uma performance ao vivo podem ser armazenados e extraídos de modo a "imitar" uma linha de entrada, podemos agora fazer que um som com aspereza alta dispare um som igualmente áspero. Ou ainda usar esse dado de comparação para buscar um som com qualidades opostas.

Nesse paradigma de descritores de dissonância/harmonia, comparar e combinálos implica, em uma primeira instância, gerar sonoridades consonantes ou dissonantes, como na sobreposição simultânea de duas sonoridades (uma díade). Mas também podemos pensar em gerar sequências de sonoridades e acordes com características em comum ou contrastantes, ou ainda em uma ordem crescente/decrescente de medidas em uma progressão harmônica. Podemos apenas adotar um descritor, ou mais de um para nos guiar em ambos processos: formar acordes, ou gerar progressões de acordes. O paralelo se torna mais evidente quando se constata que tanto Ferguson (2000) quanto Barlow (1980) exploraram esses processos, mas não em tempo real. 
A expansão e real paralelo se dá com a comparação de informações adquiridas em tempo real, como o sinal de dois instrumentos musicais sendo tocados ao vivo, ou ainda na comparação com sons pré-analisados e armazenados, assim como na Síntese Concatenativa. Tomemos como exemplo o descritor de Comonalidade de Altura, uma vez que ele é, por natureza, um descritor de comparação entre duas sonoridades. É possível então analisar uma nota musical ao vivo e comparar com dados armazenados de análises prévias, e assim buscar uma sonoridade que tenha alta ou baixa Comonalidade com o sinal de entrada, que pode ser usada para formar uma díade, um acorde. No caso, o mesmo processo pode ser aplicado para construir uma sucessão de acordes.

Levando em conta a Aspereza, o modelo não necessita de duas sonoridades ou acordes distintos para aferir uma medida, mas podemos igualmente pensar em comparar a medida de díades ou acordes distintos. No caso de formar uma díade ou acorde, podemos somar os espectros de entradas diferentes para então extrair a medida. Mais detalhes na apresentação dos objetos desenvolvidos durante a pesquisa.

Apesar de apontarmos para essa potencialidade, ela não foi devidamente explorada criativamente. Trabalhamos mais com o paradigma de Curva de Dissonância, que, na prática, também consiste em uma espécie de Descritor, mas para intervalos musicais e não de objetos sonoros em si. 


\section{Capítulo 8) Extração de Componentes Espectrais}

Neste capítulo, discorreremos principalmente sobre Análise Espectral, que é uma forma de extrair componentes espectrais de uma entrada sonora. Esses dados são necessários para alimentar os modelos psicoacústicos implementados em pesquisa, visto que necessitam de uma descrição da sonoridade em listas de frequências e amplitudes. Além disso, há outros desdobramentos em aplicações criativas, como a possibilidade de separar ruído de fundo e conteúdo tonal, exposta no capítulo 10 .

Só o fato de que os modelos psicoacústicos aqui apresentados dependem de uma representação do espectro já faz que praticamente todas as técnicas e aplicações descritas necessitem de análises espectrais, que é apenas um ponto inicial, a partir de onde ainda precisamos detectar e extrair os componentes espectrais para chegarmos em listas de frequências e amplitudes. Somente a partir daí é que esses dados são inseridos nos modelos psicoacústicos. No caso de um descritor de nível mais baixo como o Brilho, o resultado de uma análise espectral já cobre a maior parte do processo, pois apenas o cálculo do centroide espectral sobre os dados da Análise Espectral já quase corresponde ao produto final.

Uma Análise Espectral é, portanto, um requisito importante, em que apontamos alguns fatores mais relevantes. Por fim, tratamos do objeto [sigmund ], que já vem na distribuição oficial de Pure Data e possui capacidades diversas além da detecção de componentes espectrais. Com esse objeto, podemos também extrair dados para ressíntese via banco de osciladores e detectar Altura. Esses processos possuem, igualmente, um grande impacto e pertinência dentre nossas ferramentas desenvolvidas.

\section{1 - FFT (Características e Implicações)}

A Transformada Rápida de Fourier (Fast Fourier Transform, ou, simplesmente FFT) é um tipo de Análise Espectral adotada para implementações computacionais. O termo "rápido" indica que o algoritmo é otimizado para operações mais ágeis, que promovem um menor custo computacional. A análise decompõe um sinal digital em seus componentes no domínio da Frequência, e o termo "transformada" se refere justamente ao processo de "transformar" do domínio do tempo para o da frequência. A Transformada Inversa faz a conversão inversa, do domínio da frequência para o domínio do tempo. 
As análises são feitas em trechos do sinal digital, esses recortes são de um mesmo tamanho, dado pelo número de amostras. No domínio do tempo, essas amostras representam a variação de amplitude. O bloco de amostras - também chamado de "janela" - é transformado para o domínio da Frequência, onde cada amostra agora representa uma frequência que vai de $0 \mathrm{~Hz}$ (primeira amostra) até a frequência de Taxa de Amostragem.

Essa sequência de frequências é uma progressão linear, harmônica. Na FFT, há um paradigma que o bloco analisado é compreendido como um sinal periódico, tal como uma forma de onda. Esse paradigma faz com que a análise trate um som complexo qualquer como um sinal harmônico, decomposto em uma série harmônica. Nesse aspecto, há uma grande semelhança com o conceito de Síntese Aditiva, em que um tom complexo pode ser formado pela somatória de diversos tons puros. Inclusive, entende-se que a transformada inversa é um tipo de ressíntese do sinal, como se fosse feita por meio de um banco de osciladores.

Uma primeira característica é que, quanto maior o bloco de áudio, maior será a resolução em frequência. Em contrapartida, uma janela grande de tempo significa uma menor resolução de tempo, o que implica uma maior latência. Isso não gera dados bons para sons que são muito dinâmicos, com mudanças rápidas e abruptas, pois o bloco todo será compreendido como um objeto único e periódico. Em outras palavras, há sempre uma escolha entre uma boa resolução de frequências ou de tempo.

Mas, mesmo que estejamos analisando um sinal relativamente simples (harmônico, estático e com poucos componentes espectrais) - há informação de ruído gerada no processo de análise. Veja por exemplo a figura 21, que é uma análise de um sinal senoidal, consistindo apenas em um tom puro com frequência de $6 \mathrm{KHz}$. O bloco analisado é relativamente pequeno, com 128 amostras. Dessas, 64 amostras dizem respeito a um registro de frequência desde $0 \mathrm{~Hz}$ até a frequência de Nyquist $(22.050$ Hz em uma Taxa de Amostragem de 44.100). Cada ponto de amostra está então a $344.5 \mathrm{~Hz}$ de diferença do seguinte, que é a banda de frequência, dada pela Taxa de Amostragem divida pelo tamanho do bloco (44.100 / 128). Os gráficos da figura 21 plotam o resultado da análise no domínio da frequência na forma Cartesiana (coordenadas no plano complexo, formada pelas partes real e imaginaria, ou ainda amplitudes de cosseno e seno) e na forma Polar, que dá a Amplitude e Fase inicial de cada componente. Estamos mais acostumados a ler a informação do gráfico na forma Polar, mais especificamente, o gráfico de Amplitudes. 


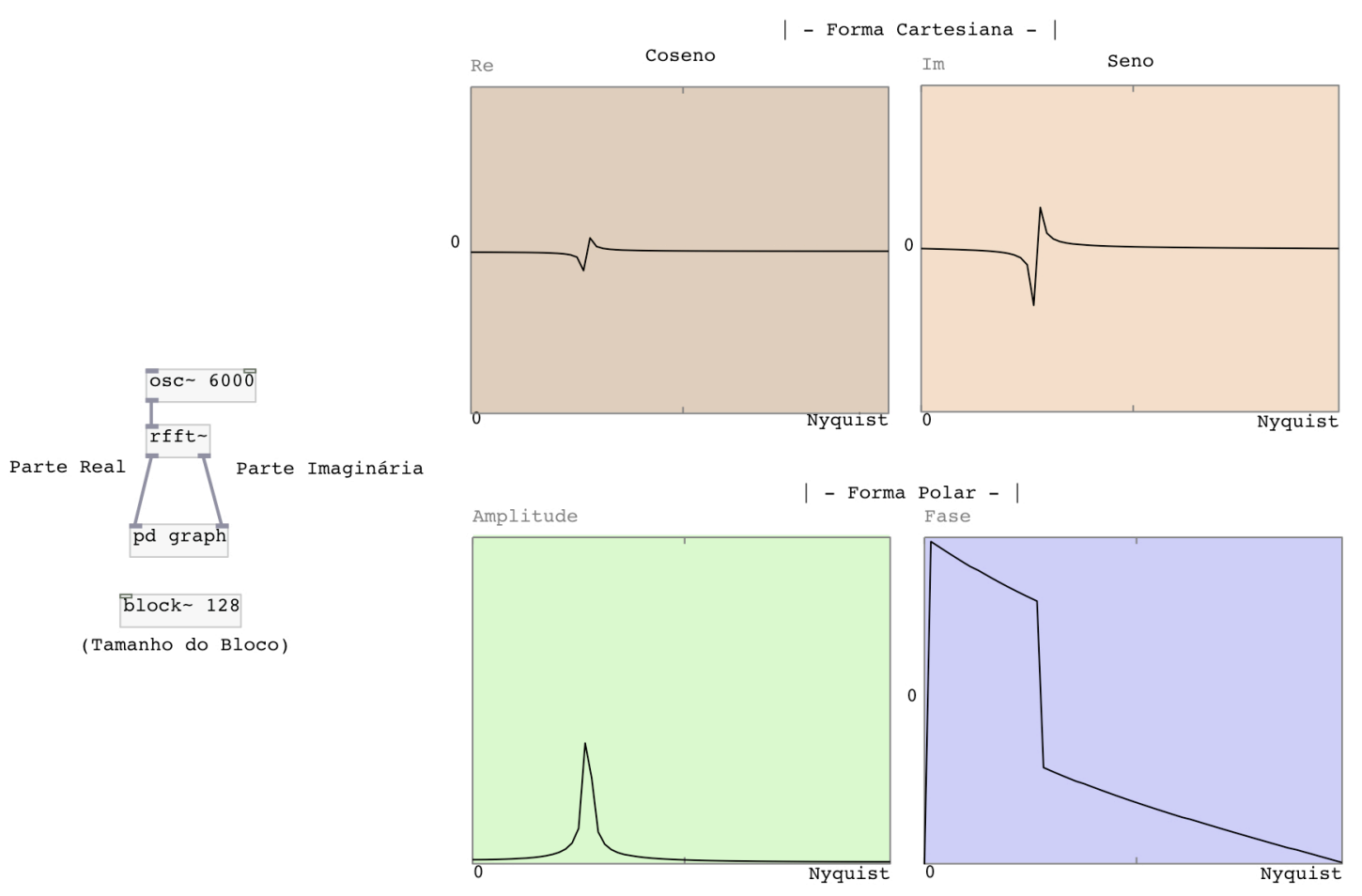

Figura 21 - Análise Espectral.

Notemos então como um componente espectral não corresponde a apenas um ponto de amplitude no gráfico verde. É possível constar artefatos em um patamar, mesmo que baixo, por boa parte do registro de frequências, e mesmo o pico em si não está em apenas um ponto de frequência. Esses dados são um reflexo direto das amplitudes das partes real e imaginária (gráficos da forma cartesiana), que possuem uma disposição similar. O gráfico das fases é o mais difícil de analisar visualmente e gera padrões gráficos e valores mesmo na ausência de valores relevantes de amplitudes.

O que se deve ressaltar é que os dados de análise sempre se caracterizam como uma aproximação. No caso acima, a banda de frequência é relativamente grande, de $344.5 \mathrm{~Hz}$. O tom senoidal analisado, a $6 \mathrm{KHz}$, não se encaixa como um múltiplo da frequência de banda de análise a $344.5 \mathrm{~Hz}$. É assim que se gera boa parte de artefatos e ruídos, pois é muito raro termos componentes espectrais que sejam perfeitos harmônicos da banda de análise. E mesmo que a análise seja feita em um bloco maior, de maior resolução, ainda se trata de uma aproximação.

O maior reflexo dessas aproximações está no gráfico das fases, que é o menos estático de todos. Se os componentes espectrais correspondessem perfeitamente aos pontos de frequência, o gráfico das fases seria mais uniforme, já que cada componente 
teria a mesma fase inicial na próxima janela de análise.

Inclusive, para uma Transformada devidamente acusar a frequência com uma melhor resolução, usa-se uma técnica baseada em computar a diferença de fase entre uma análise e outra. Veremos também uma implicação disso na implementação de Phase Vocoder, pois foi a partir do desenvolvimento dessa técnica que esse procedimento ficou conhecido.

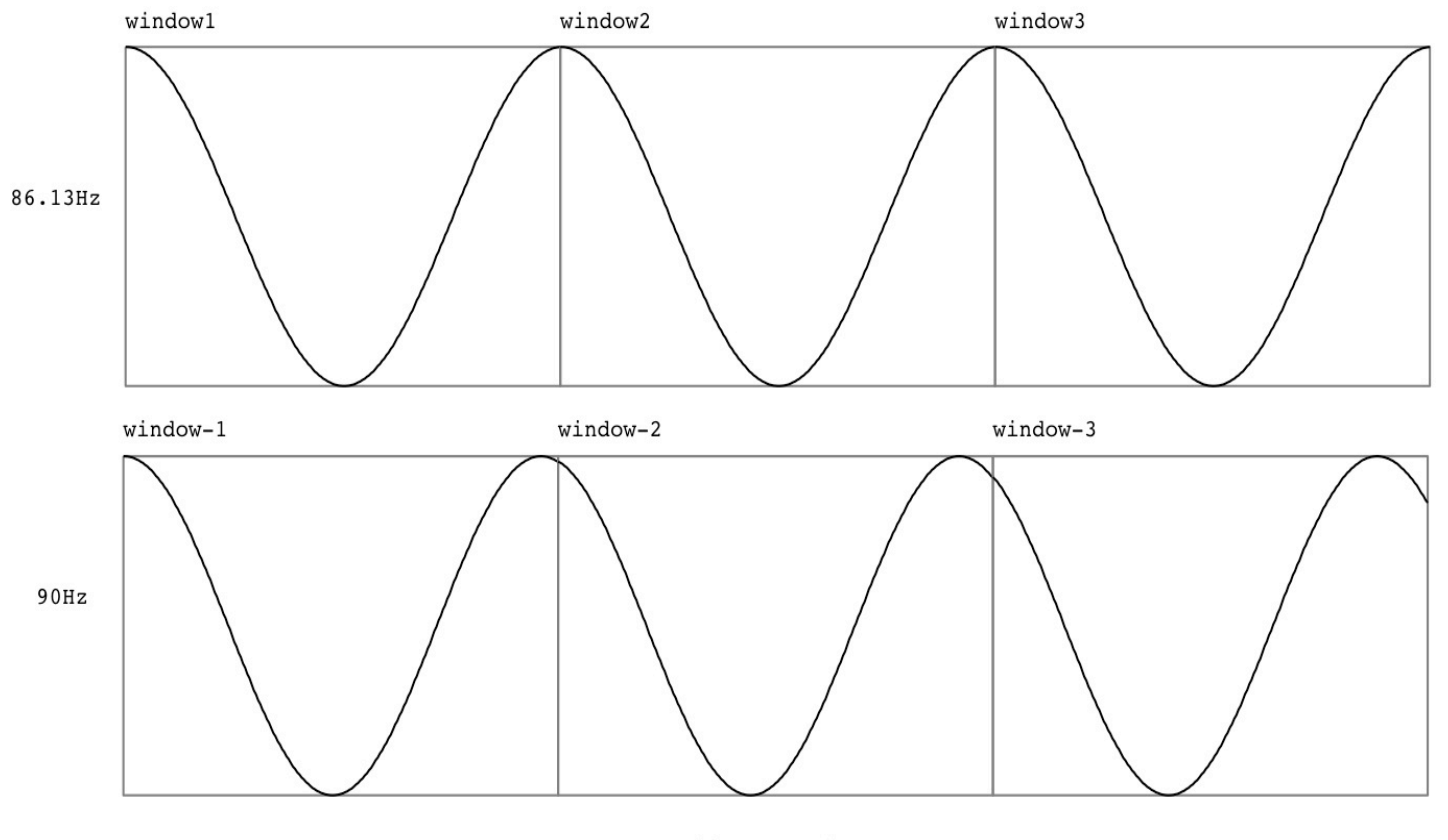

Figura 22 - Diferença de Fase entre janelas sequenciais.

A figura 22 representa blocos de áudio com 512 amostras, o que, em uma Taxa de Amostragem de $44.100 \mathrm{~Hz}$, nos dá bandas de frequência de $86.13 \mathrm{~Hz}$. Temos então uma frequência com esse exato valor na parte de cima da Figura, que cabe de modo uniforme em cada bloco de análise. Já um valor próximo, de $90 \mathrm{~Hz}$, tem um ciclo um pouco menor e gera uma diferença de fase na medida em que se sucedem as janelas de análise. Ao computar essas diferenças de fase, é possível acusar com maior acuidade qual é a frequência real analisada.

A seguir, uma implicação direta dessas considerações em um primeiro patch desenvolvido na pesquisa, baseado no objeto [sigmund ]. Esse objeto é capaz de aferir com grande precisão a frequência de vários componentes de uma análise espectral a partir desse tipo de procedimento. 


\section{2 - Extração de Listas de Parciais com [sigmund ]}

O objeto [sigmund ] possui uma série de capacidades, como a extração de parciais mais proeminentes em um espectro. Ele se encontra disponível como objeto nativo do Pure Data, e foi desenvolvido por Miller Puckette, sendo sugerido pelo autor no lugar de um objeto desenvolvido anteriormente com as mesmas funções, chamado [fiddle ] (Miller 2007). Uma versão desse objeto também está disponível como objeto externo de MAX/MSP.

O objeto recebe uma entrada direta de sinal de áudio e computa uma transformada de Fourier. A partir de operações diretas nos dados de FFT, o [sigmund ] nos entrega a Altura do som, seu envelope ou intensidade e também informação dos parciais mais intensos encontrados.

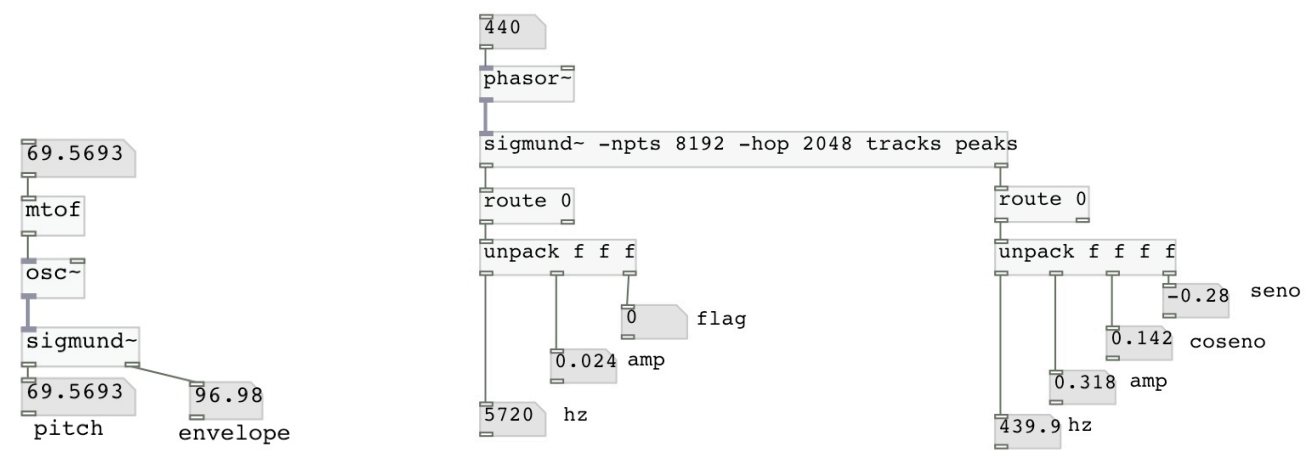

Figura 23 - funções básicas do objeto [sigmund ] em seu arquivo de ajuda.

A figura 23, à esquerda, nos mostra uma simples detecção da altura de um oscilador e seu envelope de amplitude. O padrão de inicialização do [sigmund ] é uma janela de 1024 pontos e um hop ${ }^{26}$ de 512. A altura é dada em número MIDI, cujas casas decimais equivalem a unidades em cents. A figura mostra como uma entrada de frequência em MIDI com até quatro casas decimais (duas casas decimais de um cent) foi detectada com sucesso. Essa resolução equivale a duas casas decimais de um cent. À direita da figura 23, temos o [sigmund ] fornecendo informações de componentes espectrais específicos em dois outlets, que correspondem aos argumentos tracks e peaks. O padrão é que ele detecte até 20 parciais, mas isso pode ser facilmente mudado. Os picos são dados em uma sequência de listas e o objeto [route] permite

\footnotetext{
26 Hop ("salto" em inglês) é a diferença entre duas janelas de análise de uma FFT. Nesse exemplo, o hop de 512 é a metade do tamanho da janela (1024). Outra maneira de dizer isso é que o "overlap" (sobreposição) é de 2.
} 
selecionar apenas uma delas (a primeira, em ambos os casos). A saída tracks (saída esquerda) detecta faixas contínuas de componentes espectrais e com essa informação podemos reconstituir o som com um banco de osciladores. O [sigmund $\sim$ ] também foi adotado em patches de ressíntese e detecção de altura, como veremos mais adiante. Aqui, portanto, apenas ressaltamos a extração de listas. Em peaks (saída direita do objeto), os componentes espectrais são ordenados do mais proeminente ao mais ínfimo, ou até inexistente. Por essa opção de elencar a quantidade de parciais mais intensos, esse objeto também funciona como um filtro, que podemos usar para gerar listas de até um número específico de parciais considerados relevantes.

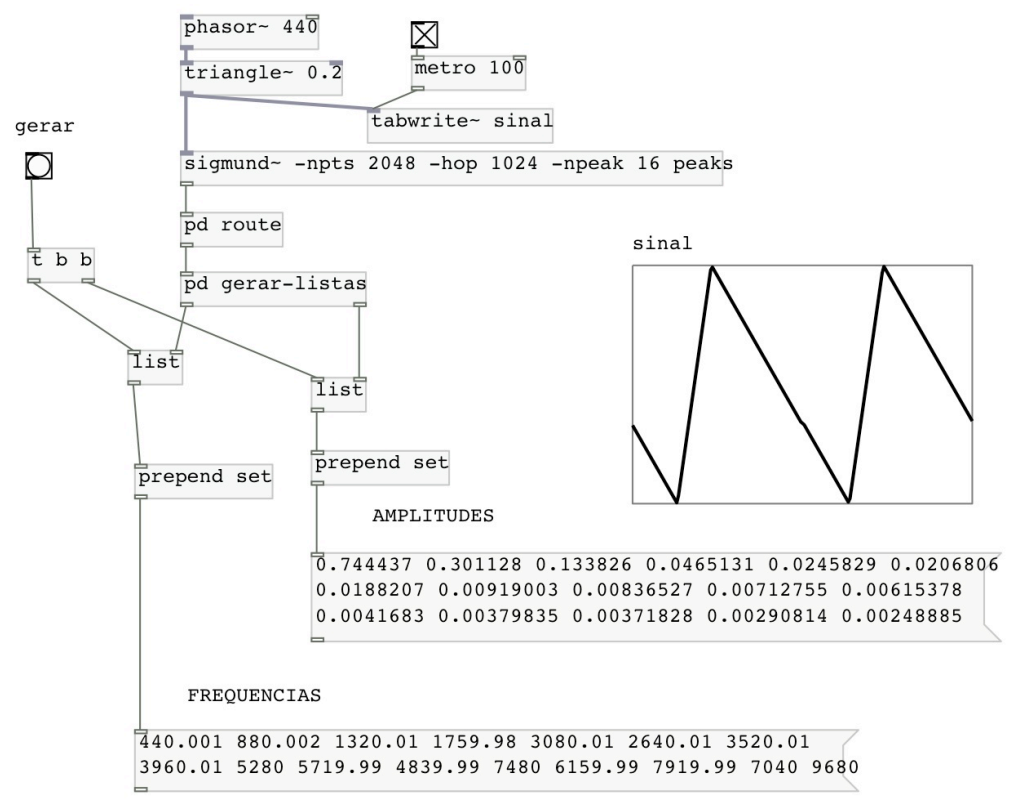

Figura 24 - Listas de Amplitudes e Frequências com o [sigmund ]

A Figura 24 é um patch de Pd que exemplifica como adotamos o objeto [sigmund ] para nos dar listas de frequências e amplitudes a serem inseridas nos modelos psicoacústicos. A análise é de uma forma de onda gerada pelo objeto oscilador [triangle ], que é capaz de fornecer formas de ondas triangulares e dente-deserra. Como a saída "peaks" nos dá os valores do parcial mais forte ao mais fraco, nem sempre teremos uma série perfeitamente ordenada de parciais do mais grave ao mais agudo. No caso acima, conseguimos uma série ordenada devido às características da forma de onda. Em todo caso, a ordenação das listas não faz diferença na entrada dos modelos psicoacústicos implementados, é apenas essencial que os termos na lista de frequência correspondam aos termos na lista de amplitudes. 


\section{Capítulo 9) Objetos Desenvolvidos}

Um código em $\mathrm{C}$ pode ser compilado para gerar um objeto e ser facilmente carregado no Pure Data como um objeto externo. Mas um código em C pode conter também um conjunto de funções e dar origem a diversos objetos como subprodutos. Nesse caso, esse código em $\mathrm{C}$ pode gerar mais de um objeto e é compreendido como uma "biblioteca". Em nossa pesquisa, desenvolvemos principalmente dois códigos em C que são bibliotecas. Um diz respeito ao modelo de Aspereza, e outro ao modelo de Comonalidade de Altura.

Além desses, temos a implementação de Brilho que foi simplesmente adotada de outra pesquisa (Bullock 2007), e a implementação do modelo de Harmonicidade de Clarence Barlow (1987), que também é uma biblioteca por resultar em mais de um objeto.

\section{1 - Objeto [sharpness]}

A implementação de Brilho (Sharpness) está de acordo com o modelo dado por Zwicker \& Fastl (1999). Um objeto de Pure Data com igual implementação já estava disponível na biblioteca de descritores de áudio de Jamie Bullock (2007). Pela simplicidade desse modelo em relação aos outros apresentados a seguir, tanto em conceito quanto implementação, pouca margem nos restou para buscar e investigar melhorias em termos de implementação e acuidade dos resultados. De tal maneira, também diferentemente das outras implementações, nada tivemos a acrescentar. Mais considerações sobre a questão do Brilho serão retomadas na discussão teórica final.

\section{2 - Biblioteca do Modelo de Aspereza}

Além do objeto [roughness], que calcula a Aspereza de um espectro, geramos dois objetos extras que são funções de conversão adotadas no processo. Veremos esses conversores primeiro, uma vez que cumprem etapas iniciais no modelo de Aspereza.

\subsubsection{Conversor de dB para Phons e Sones}

Esse objeto é um subproduto contido no modelo de Aspereza de Clarence Barlow (2008), que requer uma descrição das amplitudes na escala psicoacústica de intensidade em Sones, computadas a partir de valores em Phons. A grandeza Phon 
mede a percepção de intensidade sonora, uma vez que um som com uma mesma amplitude em decibeis evoca diferentes sensações de intensidade (loudness) de acordo com o registro em frequência.

As curvas de respostas, ou Curvas de Contorno de Loudness, foram primeiramente medidas em testes por Fletcher e Munson (1933), sendo que uma revisão dos dados foi elaborada por Robinson e Dadson (1956). Recentemente, temos a ISO 226:2003 - que é uma revisão da Organização Internacional para Padronização (ISO) feita no ano de 2003.

Por definição, em $1 \mathrm{KHz}$, um valor de intensidade em dB-SPL (pressão sonora em decibeis) equivale ao mesmo valor em Phons. Na medida em que mudamos a frequência, há uma variação de valores em Phons de acordo com a resposta perceptiva, medida em testes psicoacústicos. Portanto, dizer que a intensidade sonora é de 60 Phons significa afirmar que é tão intenso quanto um som de $60 \mathrm{~dB}-\mathrm{SPL}$ a $1 \mathrm{KHz}$.

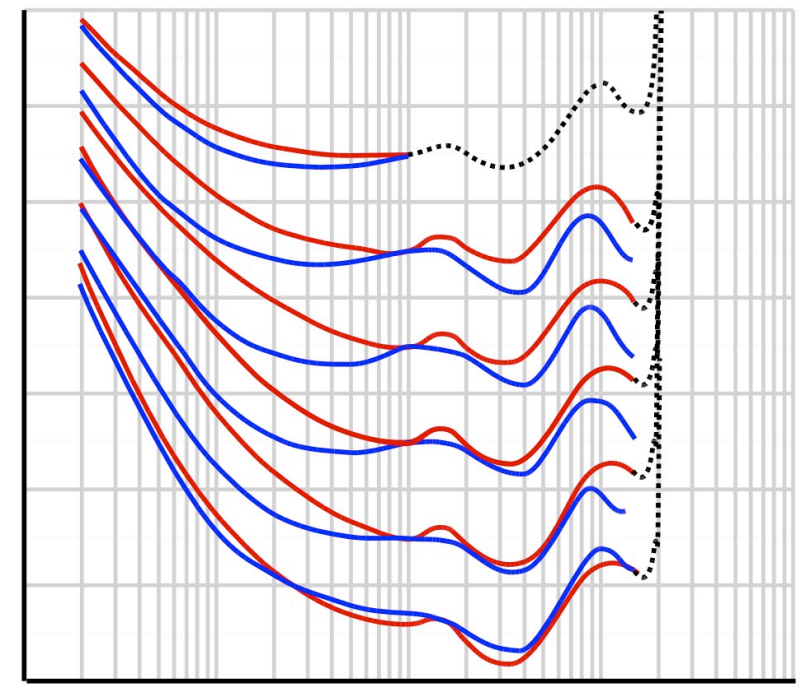

Figura 25 - Distribuição das Curvas de Loudness sobre frequências no eixo horizontal e decibéis no eixo vertical.

Por esse motivo, se temos um gráfico em $\mathrm{dB}$ no eixo vertical e frequências no eixo horizontal, linhas que representam valores fixos de Phons possuem um formato de curva. Esse tipo de gráfico representa as ditas Curvas de Iso Loudness. Na figura 25, temos um gráfico com as curvas de acordo com dois dos resultados recémmencionados. Em azul, temos uma representação dos dados obtidos por Robson e Dadson (1956). Já a revisão feita pela ISO em 2003 é dada em vermelho. De baixo para cima, as seis linhas de cada cor representam as curvas de 0,20, 40, 60, 80 e 100 Phons. 
A partir de funções, podemos emular o contorno das curvas que valores fixos de Phons representam em um gráfico dado em dB. Desse modo, é trivial encontrar o valor em $\mathrm{dB}$ a partir de um valor de frequência e outro de intensidade em Phons. Em compensação, o que mais nos interessa é justamente o contrário, achar um valor em Phons para uma frequência e sua amplitude em dB. Infelizmente, essas funções não são passíveis de inversão, o que dificulta esse processo.

Clarence Barlow (2008) codificou em Pascal funções Phon- $d B$ a partir dos dados de Robson e Dadson (1956), que emulam as curvas de Phon como apresentadas na figura 25 e possibilitam a conversão de Hertz e Phon para um valor em dB. Já para fazer a conversão contrária, uma função $d B$-Phon, por meio de tentativas de busca com a função anterior, converte Hertz e dB para Phon. Dependendo da resolução de conversão, esse processo de busca pode ser lento, o que traz uma complicação para implementação em tempo real.

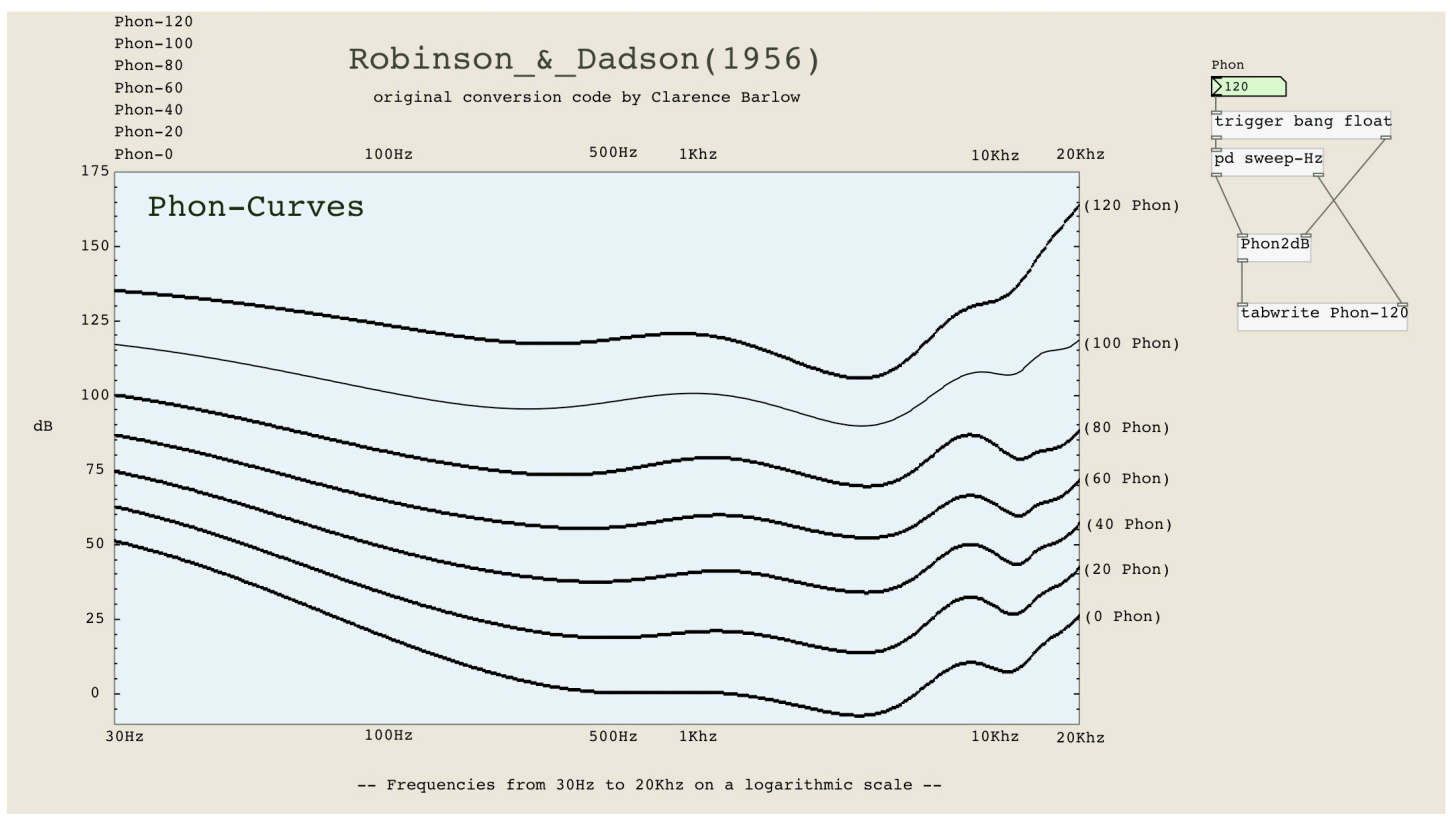

Figura 26 - Dados de Robson e Dadson, fornecidos pelo objeto [Phon2dB]

A figura 26 mostra gráficos gerados no Pure Data com um objeto compilado a partir do código original de Barlow. O objeto [Phon2dB] (Phons "to" ou "para" dB) dá uma saída de $\mathrm{dB}$ para entrada de um valor em Phons (inlet direito) e Hertz (inlet esquerdo). Usamos esse objeto para emular e representar as curvas de resultados originais da figura 25. Por meio de um subpatch, fazemos uma varredura de frequências e índices da tabela para gerar as curvas. 
A figura 27 foi gerada a partir de uma implementação em Pd de um código em $\mathrm{Matlab}^{27}$ dos dados fornecidos pela ISO226:2003. Este objeto é capaz de plotar gráficos das curvas em Phons e assim também converte uma entrada em Hertz e Phons para dB. Essa implementação tem como saída uma tabela de valores (29 apenas) para uma entrada em Phons, ou seja, ela automaticamente gera as curvas com valores de $\mathrm{dB}$ para pontos de frequências. Precisamos, assim, armazenar esses valores para consultálos. Com uma entrada em Hertz, é necessário converter esse valor para um índice da tabela, e acessar o valor via interpolação com o objeto [tabread4]. Tanto a resolução de pontos, como o registro de Phons desse objeto são menores do que o código fornecido por Clarence Barlow. Portanto, mesmo se tratando de uma revisão dos dados, o trabalho de Clarence Barlow nos fornece uma conversão bem aprimorada, além da possibilidade de converter $\mathrm{dB}$ para Phons.

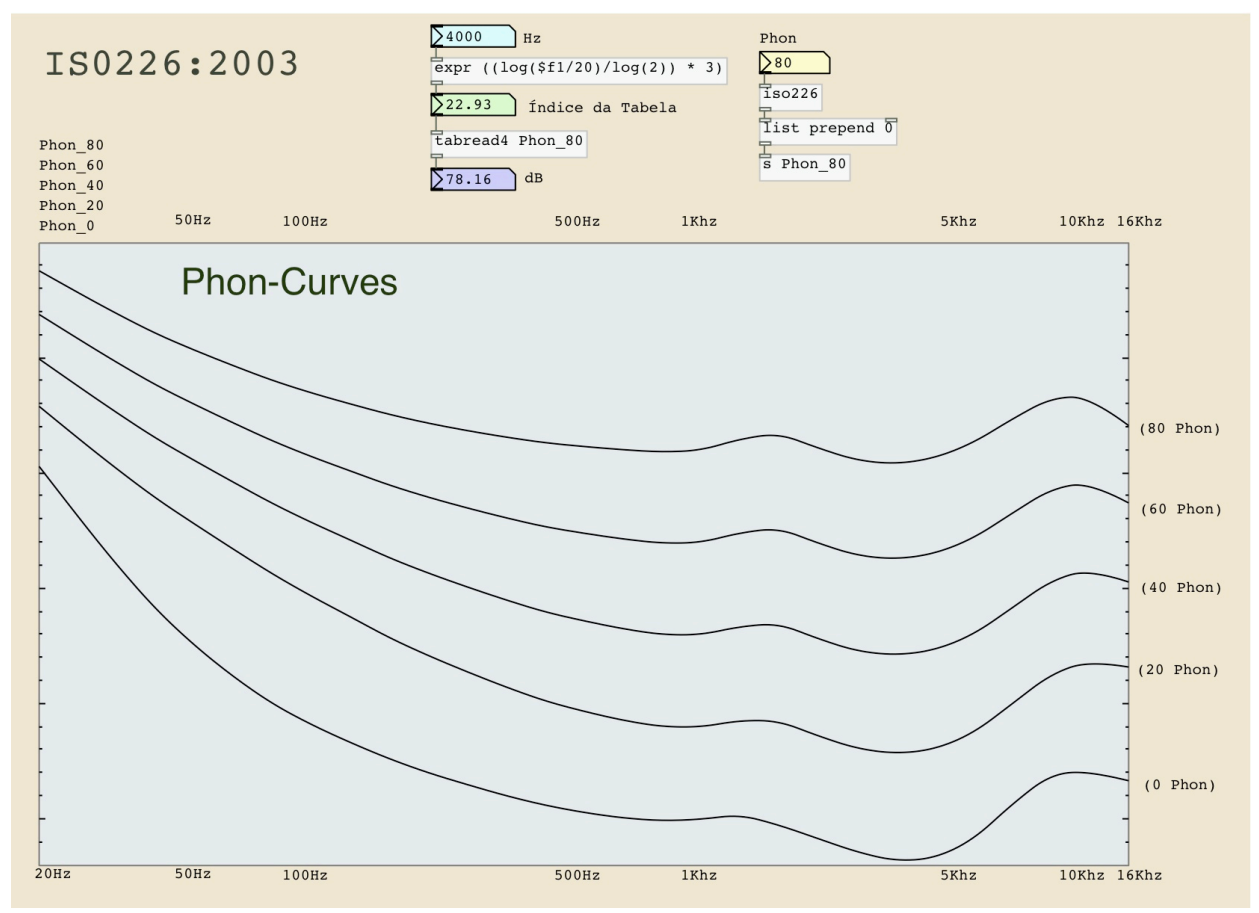

Figura 27 - Dados da ISO226:2003 fornecidos pelo objeto [iso226]

Apesar de ser redimensionada de acordo com nossa resposta de escuta, a medida em Phon ainda remete à escala logarítmica de decibeis. Por isso, ela não é uma escala que dimensiona a percepção de variação da intensidade sonora, que dobra para um acréscimo de 10 Phon. Para isso, convertemos Phons para Sones, em que o valor 
em Sones dobra ou divide-se pela metade a cada variação em um fator de 10 Phons acima ou abaixo. Assim, comparando diferentes medidas em Sones, fica evidente a relação intervalar de intensidade sonora entre uma amplitude e outra.

A figura 28 mostra a conversão de uma amplitude linear para Sones. Primeiramente, usamos o objeto nativo de Pure Data que converte amplitudes lineares para dB. Em um segundo passo, usamos outro objeto implementado em nossa pesquisa, que corresponde também ao código de Clarence Barlow e que converte uma entrada em dB e Hertz para Phons. O objeto [phon] faz a conversão por meio de uma heurística, ou seja, tentativas de busca e aproximações sucessivas com a função existente no objeto $[$ Phon $2 \mathrm{~dB}]$ e, por esse motivo, pode ser custoso computacionalmente. Temos também na figura outros objetos nativos e uma implementação por meio do objeto [expr] para converter Phons em Sones.

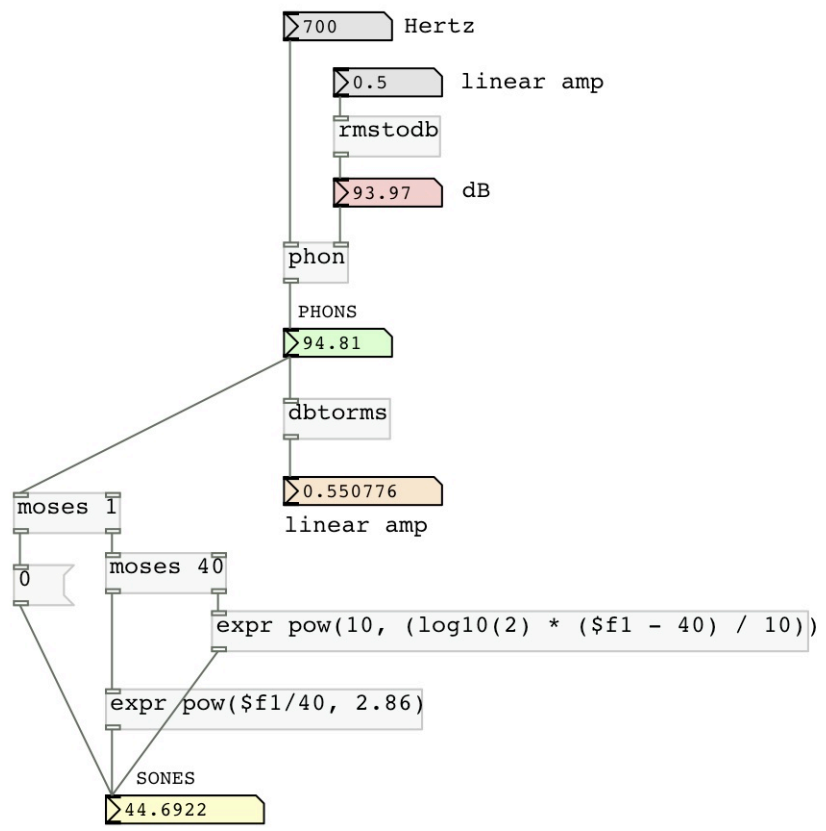

Figura 28 - Conversão de Amplitudes para Phons e Sones

É comum que as amplitudes sejam dadas em "valores lineares", como é a saída do objeto [sigmund ]. Esses valores variam entre 0 e 1 e podem ser convertidos para decibeis com o objeto [rmstodb], nativo do $\mathrm{Pd}$. Ao converter a amplitude linear para $\mathrm{dB}$, podemos convertê-la para Phons, o que contabilizará uma mudança acima ou abaixo de acordo com nossa curva de respostas. Esse redimensionamento das amplitudes pode ser convertido de volta para valores lineares. A partir desse processo, 
temos um redimensionamento das amplitudes de acordo com nossa percepção de intensidade, o que pode ser muito útil como entrada de dados em modelos psicoacústicos. Essa conversão de volta a valores lineares é possível com o objeto inverso, também nativo do Pd, chamado [dbtorms]. Na figura 28, vemos como uma entrada de amplitude linear variou de 0.5 para 0.550776 .

Veremos adiante outro procedimento que Parncutt (1989) adota em seu modelo de Comonalidade de altura para redimensionar os valores de intensidade de acordo com nossa resposta perceptiva. Mas, trata-se de um modo muito mais simples, que apenas contabiliza um nível de $\mathrm{dB}$ acima do nível de limiar da escuta.

\subsubsection{Conversão de Hz para a Escala da Banda Crítica (Barks)}

Outro subproduto da implementação do modelo de Aspereza é a conversão de Hertz para Barks - a escala da banda crítica de acordo com os dados de Zwicker (1961). A banda crítica é um dado essencial no modelo de Aspereza, uma vez que o resultado de Plomp e Levelt é uma curva de resposta tendo como base a banda crítica.

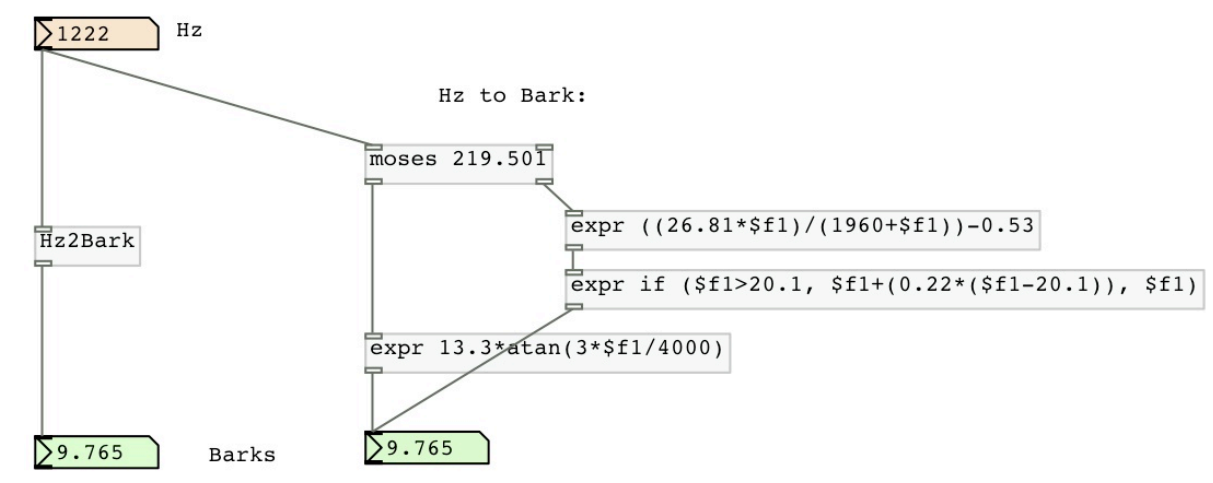

Figura 29 - Conversão de Hertz para Barks

A conversão de Hertz para a escala da Banda Crítica é dada por funções que aproximam os resultados dados pela tabela 7. Traunmüller (1990) fornece uma equação com um erro entre mais e menos 0.05 Bark para frequências acima de $100 \mathrm{~Hz}$. Já a conversão pela fórmula de Terhardt (1979) possui uma melhor precisão nas frequências do registro grave. Uma combinação sugerida por Clarence Barlow (2008) dessas duas fórmulas oferece o resultado de maior acuidade de conversão e foi implementada como um objeto conversor assim como parte do processo de cálculo do modelo de Aspereza no objeto [roughness], explicado a seguir. A Equação de Terhardt 
(1979) é usada, então, para frequências cujo valor em Hertz é menor ou igual a 219.5 Hz, enquanto utilizamos a de Traunmüller (1990) para os valores superiores - vide figura 29.

\subsubsection{Objeto [roughness]}

O modelo de Aspereza foi implementado primeiramente como um subpatch de Pure Data e depois na forma de um objeto (com o termo em inglês: [roughness]). A implementação em objeto foi necessária para interação em tempo real, pois essa versão possui uma performance muito mais rápida, como demonstraremos aqui.

Alguns modelos de Aspereza baseados em Plomp e Levelt - descritos no capítulo 5 - foram contemplados no objeto. Foi possível remeter a mais de apenas um porque a estrutura geral é a mesma, o que muda é apenas alguns parâmetros. Veja a figura 30, que é a estrutura geral interna do subpatch e que corresponde à Figura 8 da seção 5.2, do diagrama do modelo de Aspereza.

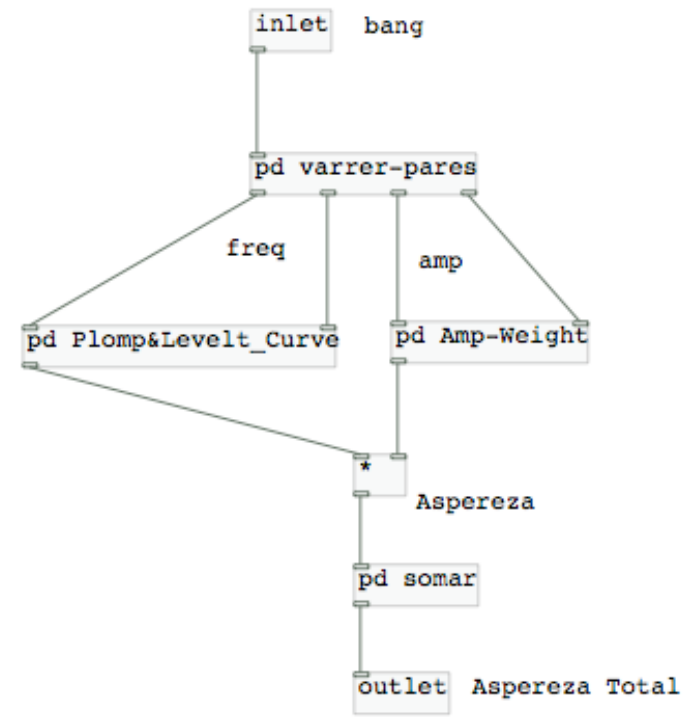

Figura 30 - Subpatch de Aspereza

O patch se alimenta de listas de amplitude a frequências de um espectro, fornecido pelo objeto [sigmund ]. Essas listas são alocadas em tabelas que são varridas para enviar todas as combinações de pares dos parciais. O par de frequências é usado para encontrar a diferença na escala bark e buscar um valor de Aspereza segundo o estudo de Plomp e Levelt. Esse valor é então redimensionado de acordo a um Peso de Amplitude obtido a partir do valor do par de amplitudes. Um acumulador 
soma o valor de Aspereza de todas as combinações de parciais, que nos dá a Aspereza total para o espectro de entrada.

A diferença de parâmetros está, primeiramente, em dois desses elementos básicos: a aproximação dos resultados de Plomp e Levelt e o tipo de Peso de Amplitude. Foram adotadas duas funções distintas para aproximar a curva de Plomp e Levelt, uma de Parncutt (1993) e outra de Sethares (1999). Antes de contabilizar as diferentes opções de Peso de Amplitudes, podemos redimensionar os valores de amplitude de acordo com um modelo de mascaramento em um passo inicial, seguido de um redimensionamento em Phons (como exemplificado na Figura 28) e, por fim, uma conversão em Sones. A partir dessas opções e grandezas de intensidade (dB, Phon e Sones), temos então três tipos de Pesos de Amplitudes, que correspondem a três modelos de base diferentes: Vassilakis (2001), Barlow (2008) e Sethares (1999), são eles:

- Vassilakis: Grau de Flutuação de Amplitude;

- Barlow: Extrair a média quadrática;

- Sethares: Considerar o menor dos valores.

Com essas diferentes possibilidades de parametrização, foi possível pesquisar as características e influências de cada parâmetro na medida final de Aspereza. Dentre as possíveis combinações, podemos tomar o modelo de Barlow e inserir o de Vassilakis, como proposto anteriormente na seção 5.2, mas também podemos ter os modelos originais desses três autores (Vassilakis, Barlow e Sethares).

Sobre as duas opções de aproximação da Curva de Plomp e Levelt (1965), a de Sethares é usada por ele mesmo (Sethares 1999) e também por Vassilakis (2001) - que o revisou e incluiu nele apenas seu método de Peso de Amplitudes. Mas o modelo original de Sethares não está completamente contemplado em nossa implementação, tendo sido ligeiramente revisado, pois adotamos um método mais acurado de conversão de frequências para barks. Mesmo assim, consideramos que o resultado ainda corresponde ao mesmo modelo, já que não promovem uma diferença tão significativa.

O modelo original de Sethares (1999) adota sua aproximação da curva de Plomp e Levelt, amplitudes lineares sem mascaramento e o menor valor de um par de amplitudes como peso de amplitude. Vassilakis revisa e apenas inclui sua fórmula do “Grau de Flutuação de Amplitude", em vez da menor das amplitudes. Já o modelo de Barlow adota a aproximação da curva de Parncutt, um modelo de mascaramento e a 
média quadrática das amplitudes em Sones.

O objeto, então, muda de parâmetro de acordo com os seguintes comandos:

- curve: Aproximação da Curva de Plomp e Levelt $(0=$ Parncutt, $1=$ Sethares);

- masking: Mascaramento $(0=$ desligado, $1=$ ligado $)$;

- loudness: Grandeza de Amplitude $(0=$ Amplitude linear, $1=$ Phons, $2=$ Sones);

- weight: Peso de Amplitude ( $0=$ Vassilakis, $1=$ Barlow, $2=$ Sethares $)$.

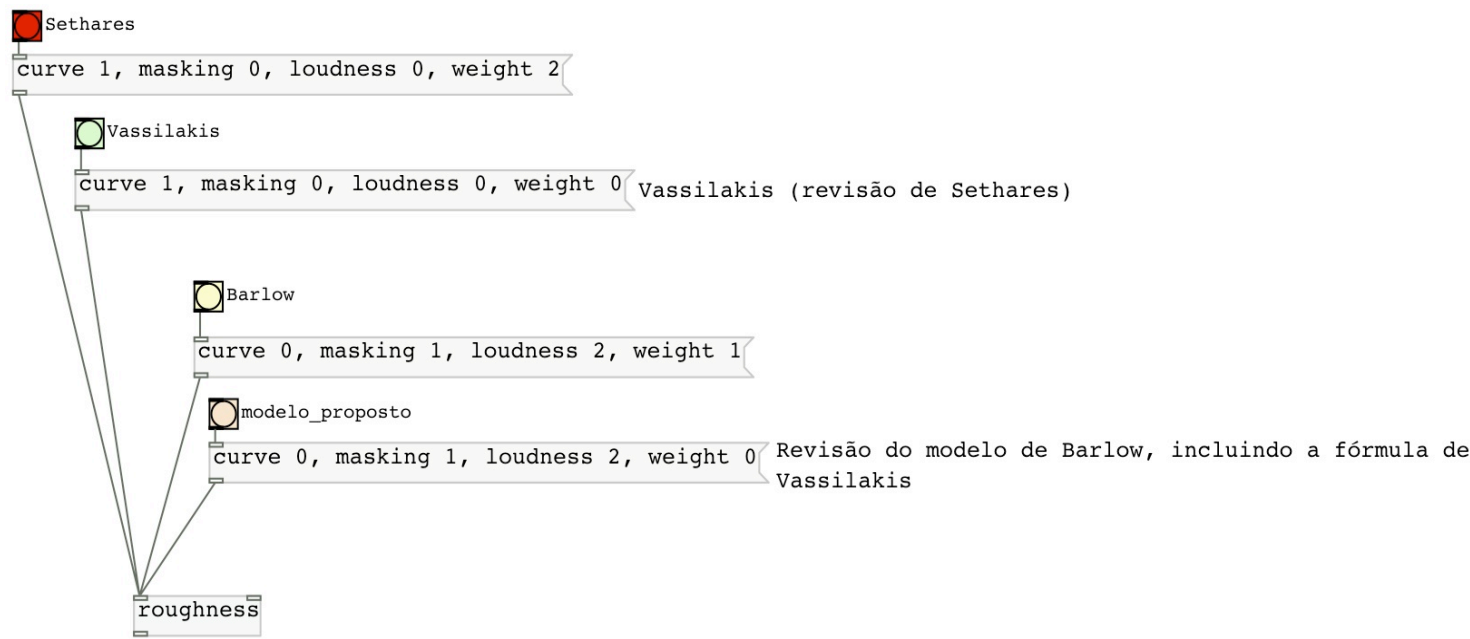

Figura 31 - Parametrização do objeto [roughness] por meio de comandos enviados a ele. As quatro opções acima representam 4 tipos de modelo.

Note-se, na figura 31, como os três modelos de base podem ser parametrizados com esses comandos, além da parametrização proposta nesta pesquisa. Uma discussão pormenorizada da diferença entre cada implementação será dada na discussão teórica da parte final.

\subsubsection{Performance do Objeto [roughness]}

A figura 32 compara a performance da implementação em objeto e em um subpatch de Pure Data. Os parâmetros aqui usados foram curve 0 / masking 0 / loudness 0 / weight 1 , que correspondem ao modelo de Barlow com a entrada de amplitude linear e sem mascaramento.

O sinal analisado provém de uma forma de onda que é a mesma da Figura 24, sendo que agora se trata de uma díade com as fundamentais de 400 e 430 hertz. A análise - feita no subpatch [pd listas(sigmund )] - gera listas de Frequências e Amplitudes dos 32 parciais com mais energia no espectro e as aloca em tabelas. 


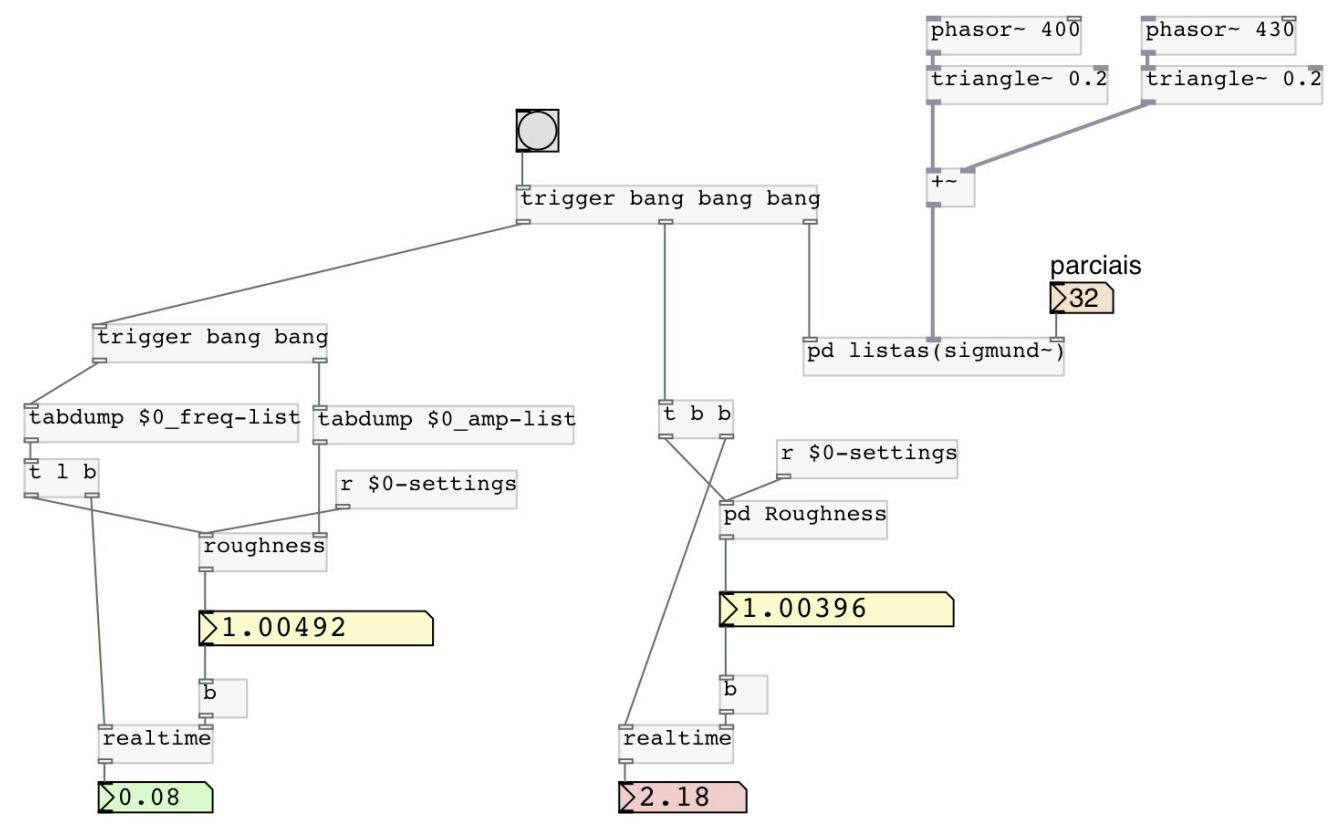

Figura 32 - Comparação de performance de processamento.

A pequena variação dos resultados entre a implementação em subpatch e a do objeto compilado em $\mathrm{C}$ ocorre pelo fato de que o cálculo dentro do objeto atende a uma resolução diferente em bits. Eis que, na soma de todas as combinações dos 32 parciais (total de uma soma de 496 valores), essa discrepância aparece, mas, no caso de poucas combinações, ela pode retornar o mesmo valor que a implementação em patch. O teste de velocidade de processamento foi aplicado em um Macbook Pro Intel Core i7 $2.66 \mathrm{GHz}$.

A figura acima nos mostra que a soma de Aspereza para todas as combinações de pares de parciais demorou 2.18 milissegundos na implementação em subpatch e apenas 0.08 milissegundo na implementação em objeto, que é uma diferença muito grande. 2.18 milissegundos já é uma latência maior do que um bloco de áudio de 64 amostras em uma Taxa de Amostragem de $44.1 \mathrm{KHz}$. Ou seja, não é uma performance boa para tempo real.

A seguir, um exemplo de como a conversão para Phons pode ser computacionalmente pesada. O teste é feito no objeto [roughness], mas também diz respeito ao objeto [phon] apresentado anteriormente, uma vez que se trata do mesmo código. Ao compararmos com o resultado acima, fica evidente como há uma diferença realmente muito grande de performance, chegando a 2.44 milissegundos em vez de 0.08 milissegundo. 

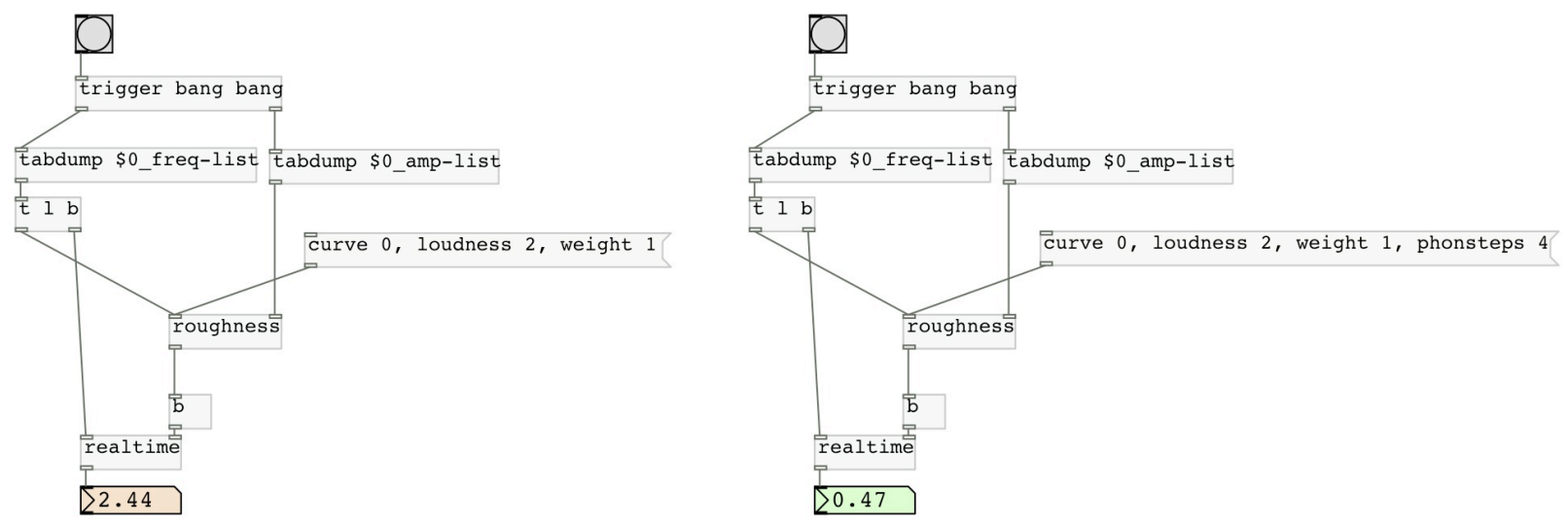

Figura 33 - Testes de performance com a conversão em Phons

Para otimizar esse cálculo, incluímos um novo comando que diminui a resolução de conversão para Phons, sendo que o objeto [phon] também obedece a esse comando. Lembrando que há uma heurística de programação, como descrita na seção sobre o objeto [phon], podemos definir o número de passos, ou tentativas, em que o algoritmo busca converter de $\mathrm{dB}$ para phons. O controle é dado pelo envio de uma mensagem "phonsteps", que define o número de passos. Com apenas 4 passos (valor mínimo) chegamos a um resultado de performance de 0.47 milissegundo. Mais considerações sobre os parâmetros dos objetos serão trazidas na discussão final.

\section{3 - Biblioteca de Pitch Commonality}

O cálculo de Comonalidade de Altura em si é simples e feito sobre o perfil de Saliência de Alturas, ou melhor, através da comparação entre dois ou mais perfis de Saliência de Altura. O maior trabalho está justamente em gerar o perfil de Saliência de Altura, que é um processo com vários passos que dependem da estimativa de outros elementos, como o Peso de Altura Virtual e a Multiplicidade. Em paralelo com esses dados, podemos também gerar medidas de Tonalness.

Desse modo, com o mesmo código, pudemos gerar diferentes objetos para calcular Peso de Alturas, Tonalness, Perfil de Saliência, Multiplicidade e Baixo Fundamental (ou Fundamental do Acorde), além do cálculo de Comonalidade de Altura em si. Primeiramente, demonstraremos uma implementação em patch de Pure Data, que serve de recurso didático e também para testar ganhos de performance com a versão em objeto. 
De qualquer maneira, a motivação maior de construir objetos não foi exatamente a performance, mas sim uma grande conveniência para chamar funções diferentes e mudar a estrutura e comportamento dos objetos, principalmente o de Comonalidade de Altura.

\subsubsection{Implementação do Código de Parncutt em Patch de Pure Data}

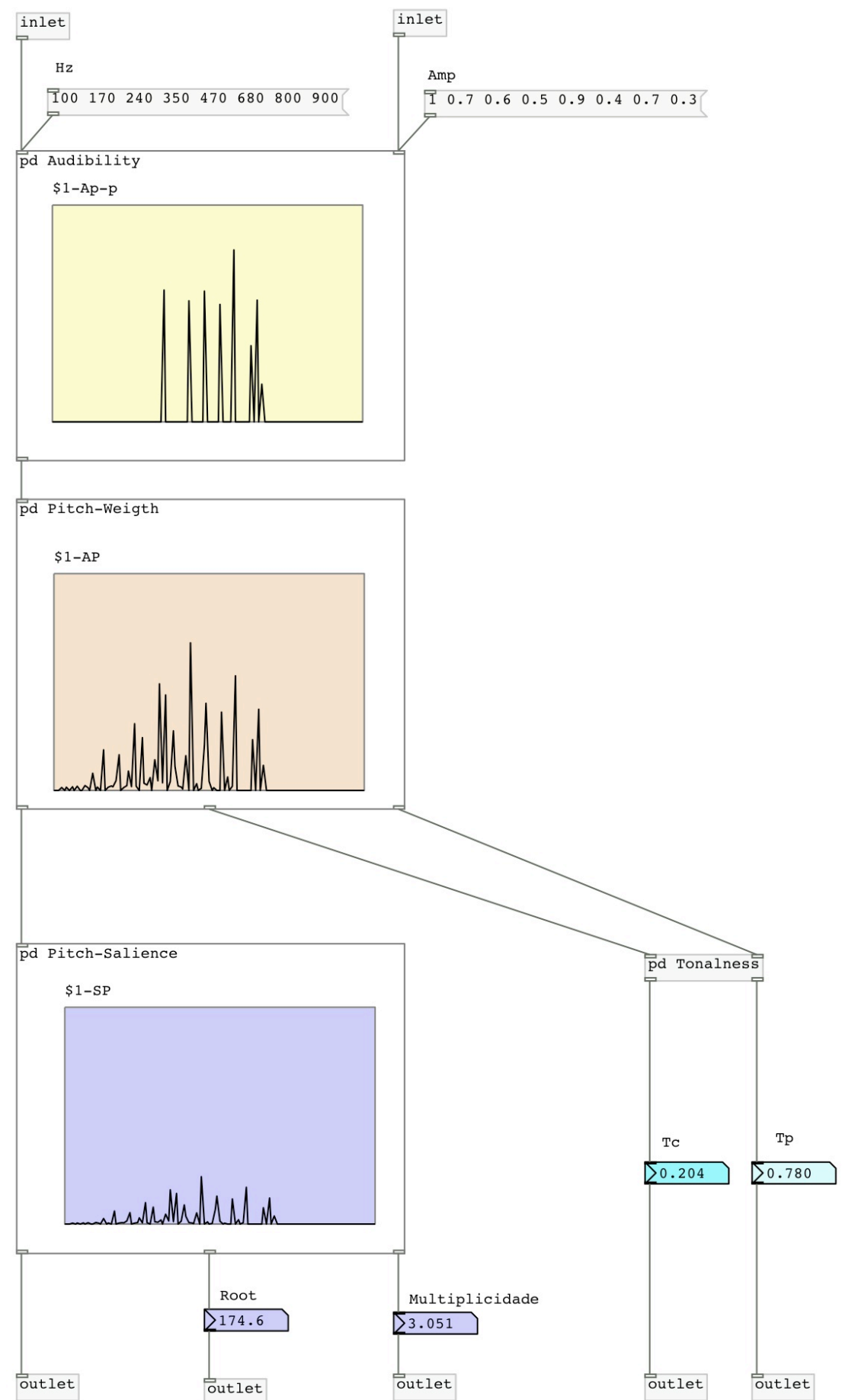

Figura 34 - Implementação do Perfil de Saliência, Tonalness e subprodutos. 
A figura 34 é uma Abstração de Pure Data que calcula o Perfil de Saliência de Altura (o dado essencial para calcular a Comonalidade de Altura), mas calcula também Tonalness e outros subprodutos como a Multiplicidade e o Baixo Fundamental. O fluxo de dados remete bastante aos diagramas apresentados anteriormente na seção sobre a descrição dos modelos (ver figuras 5 e 6). Como os detalhes conceituais já foram descritos, apenas apresentamos a organização estrutural e os valores de saídas, sem explicar novamente do que se trata cada elemento.

A entrada inicial, como no objeto [roughness], são listas de Amplitude e Frequências. Em um primeiro estágio, temos a análise da entrada de Frequências e Amplitudes, onde geramos o que é entendido como "Espectro Audível". Um gráfico dessa medida do espectro se encontra na primeira tabela, em amarelo, que representa pontos de frequências com amplitudes em valores de Audibilidade para Tons Puros (ou Peso de Altura Espectral). Esse gráfico é da mesma ordem que os gráficos de amplitudes obtidos por análises espectrais (da figura 21, por exemplo) e é a saída do outlet desse primeiro subpatch.

O segundo subpatch repassa essa entrada para o outlet direito e calcula a Audibilidade de Tom Complexo (ou Peso Virtual de Altura), que é repassada para o outlet do meio. Com essas duas saídas, é possível calcular o Tonalness Puro e Complexo do espectro, o que é feito em no subpatch seguinte [Pd Tonalness]. Ainda nesse segundo subpatch, temos a tabela que representa o Perfil de Audibilidade (ou Peso de Altura), que é uma combinação das duas medidas anteriores e a entrada para calcular o perfil de Saliência de Alturas e os valores que aparecem visualmente na tabela.

Na última seção, um dado essencial é o cálculo de Multiplicidade, que é enviado pelo outlet direito. A tabela representa o Perfil de Saliência de Altura, que é a saída do outlet esquerdo e a entrada de cálculo de Comonalidade de Altura. Um subproduto final é o Baixo Fundamental ou Fundamental do Acorde, que é dado pela maior Saliência de Altura.

A figura 34 corresponde ao código original de Richard Parncutt ${ }^{28}$. Isso significa que os pontos de frequência das tabelas representam 120 notas no sistema igualmente temperado. Ou seja, 12 notas por oitava, sendo dez oitavas ao todo. Uma resolução maior de frequências é importante para sons inarmônicos e/ou Sistemas de Afinação

\footnotetext{
28 Disponível em $<$ http://www.uni-graz.at/ parncutt/parpitchcode.html>.
} 
alternativos.

O dado de análise que mais se beneficia com uma boa resolução de frequências é a Fundamental do Acorde. No exemplo dado acima, temos uma lista de frequências de um som inarmônico, que não corresponde exatamente a notas do sistema temperado. Em compensação, o Baixo fundamental encontrado $(174.6 \mathrm{~Hz})$, parece estar próximo do segundo parcial $(170 \mathrm{~Hz})$, mas a verdade é que a diferença é de 46 cents - quase um quarto de tom, que é a máxima diferença possível com essa resolução. Logo, uma divisão da oitava em quartos de tom pode acusar com mais precisão esse segundo parcial como a Altura mais Saliente do espectro. Outros exemplos a respeito dessa questão virão a seguir.

Uma maior resolução com mais notas por oitava é possível em abstração, mas sua praticidade maior é em uma implementação em objeto. Sobre a questão de resolução, destacamos a conveniência de divisões da oitava em 24, 36, 48 e 72 partes iguais, que correspondem, respectivamente, a uma subdivisão microtonal em quartos, sextos, oitavos e doze-avos de tom. O quanto isso reflete em número de pontos na tabela é estabelecido pela operação trivial de multiplicar pelo número de oitavas (10).

A divisão em 72 pontos é um múltiplo que contém os mesmos intervalos de quartos e sextos de tom e é um sistema de afinação apontado por Navarro (1927) como muito conveniente por conter boas aproximações de intervalos dos harmônicos de uma série. Ou seja, podemos representar bem uma série harmônica com esse sistema. O terceiro harmônico (702 cents) já é bem aproximado no sistema temperado. O décimo primeiro harmônico é próximo de um quarto de tom (551 cents), o sexto de tom aproxima bem o sétimo harmônico (969 cents) e o quinto harmônico (386) é próximo de um sistema de doze-avos de tom.

Ainda outra possibilidade é inserir afinações alternativas e divisões desiguais quaisquer. Mas o que seria particularmente eficaz para qualquer caso seria adotar uma espécie de contínuo de frequências, que comportaria qualquer intervalo musical sem restrição a escalas. O problema é que nada no computador pode ser infinitamente contínuo, então precisamos definir uma resolução, que pode ser de 1 cent, ou seja, 12.000 pontos. Uma maior resolução traz o problema de que o gasto computacional aumenta proporcionalmente. A versão em objeto, nesse caso, é essencial para uma melhor performance.

Vejamos agora uma implementação completa do modelo em um patch de Pure Data, apresentada na figura 35. Analisamos dois sons em tempo real. Ambos estão em 
uníssono, o que deveria dar uma Comonalidade de Altura igual a 1. Entretanto, pela pequena diferença no conteúdo espectral das formas de onda ${ }^{29}$, o resultado é apenas próximo a 1 .

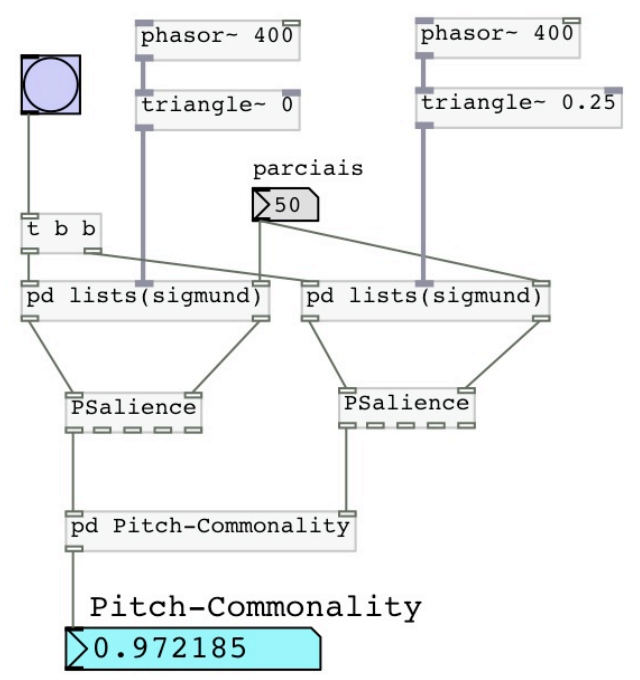

Figura 35 - Comparação de duas sonoridades com o Modelo de Comonalidade de Altura, implementado em um patch de Pure Data.

As duas abstrações [PSalience] correspondem à figura 34. As listas de amplitude e frequência (com 50 parciais) são dadas do mesmo modo que apresentado anteriormente, com o objeto [sigmund ]. O subpatch [pd Pitch-Commonality] recebe os dois Perfis de Saliência e calcula a medida de comparação. Veremos a seguir a implementação dessas diferentes etapas em uma organização em objetos.

\subsubsection{Objeto [tonalness]}

Apesar de ser apresentado por Parncutt (1989) junto ao modelo de Comonalidade de Altura (e também estar presente na implementação de seu código original em C), o modelo de Tonalness é, na verdade, um elemento extra e desnecessário para o cálculo de Comonalidade de Altura. Mais do que isso, como já exposto pela classificação de Terhardt (1984), esse atributo faz parte de um grupo distinto de elementos, os da classe de Dissonância Sensorial.

O objeto [tonalness] corresponde aos primeiros passos expostos na descrição da abstração [PSalience], mostrada na figura 34, em que simplesmente se desconsidera o cálculo de Perfil de Audibilidade e, por consequência, o de Multiplicidade e Perfil de

29 Uma onda dente-de-serra, dada pelo objeto [triangle ] com argumento 0, e outra forma de onda que está entre uma onda dente-de-serra e uma onda triangular, como na figura 24 e outros exemplos anteriores, também dada pelo objeto [triangle ] com argumento 0.25 . 
Saliência. O argumento corresponde à resolução da tabela, discutida anteriormente, ou melhor, à divisão da oitava, que, no exemplo da Figura 36, é uma divisão da oitava em 12, padrão no caso da falta de um argumento. É possível mudar essa resolução e até enviar escalas específicas, como exemplifica-se no arquivo ajuda do próprio objeto.

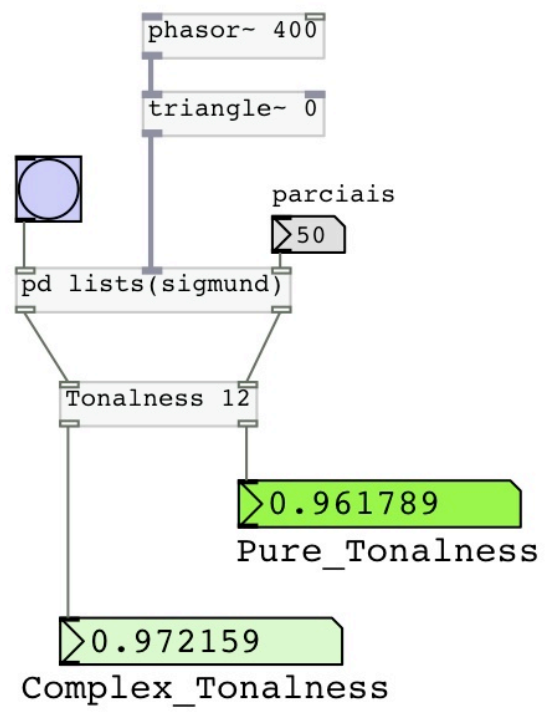

Figura 36 - Medida do objeto [tonalness].

Diferentemente dos objetos [Pitch_Weight] e [Pitch_Salience], descritos a seguir, o objeto [tonalness] dá apenas um único número de saída em seus outlets, que são as medidas de Tonalness Puro (saída direita) e Complexo (saída esquerda). Mais uma vez, usamos o [sigmund ] para gerar listas de amplitudes e frequências.

\subsubsection{Objeto [Pitch_Weigth]}

As saídas desse objeto são as mesmas que se encontram no segundo subpatch da Figura 34, que correspondem (da direita para a esquerda) ao Peso de Altura Espectral, Peso de Altura Virtual e Peso de Altura. A resolução de frequências é referida da mesma maneira que o objeto [tonalness], onde o padrão é uma divisão da oitava em 12 intervalos iguais.

Os dados de saída desse objeto dizem respeito ao modelo de Altura virtual, que é o elemento chave para o cálculo de Tonalness e Perfil de Saliência. Por ter essa importância chave e representar um resultado de Altura Virtual, dedicamos um objeto especialmente para esse estágio.

No exemplo da Figura 37, estamos analisando um som definitivamente 
harmônico - uma onda dentre-de-serra que possui bastante energia por todo o espectro. Extraímos listas de amplitudes e frequências de 50 parciais, o que é relativamente um número grande. Por se tratar de um som harmônico, a frequência que corresponde à fundamental ganha um peso de Altura Virtual evidentemente muito maior em relação aos outros. Vejamos os resultados obtidos pela análise.
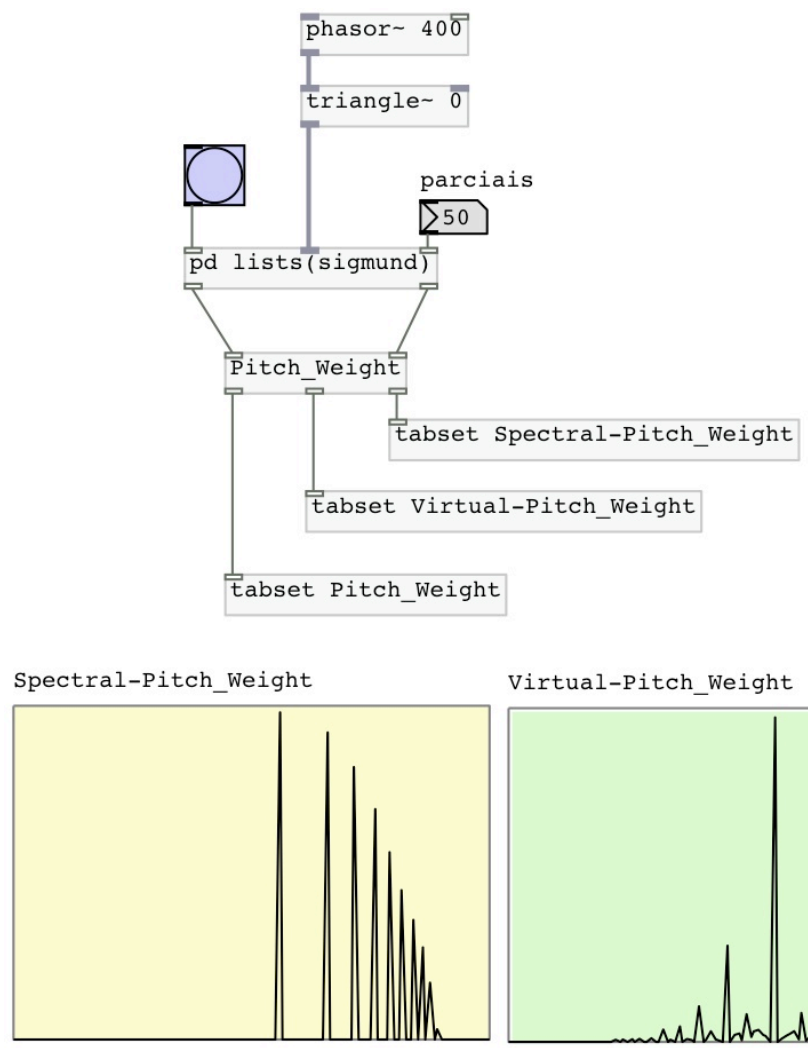

Virtual-Pitch_Weight

Pitch_Weight

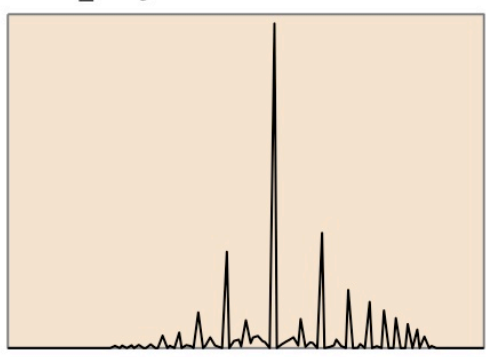

Figura 37 - Objeto [Pitch_Weight] e suas saídas.

A primeira tabela de Peso de Altura Espectral aponta os parciais mais proeminentes, e as tabelas seguintes demonstram como Alturas Virtuais são encontradas a partir de um reconhecimento de padrão harmônico. Por isso, podemos notar picos menores acusados em uma porção mais grave do registro que não estão presentes na primeira tabela, e um maior valor ao parcial que é a fundamental do espectro harmônico. 


\subsubsection{Objeto [Pitch-Salience]}

Seguindo o mesmo padrão, o objeto [Pitch-Salience] corresponde ao último estágio da abstração de Pure Data apresentada na Figura 34 e possui a mesma estrutura dos objetos anteriores. A saída do Perfil de Saliência de Altura corresponde bastante ao resultado de Peso de Altura. Podemos constatá-lo ao compararmos o resultado da figura 37 com a figura 38 .
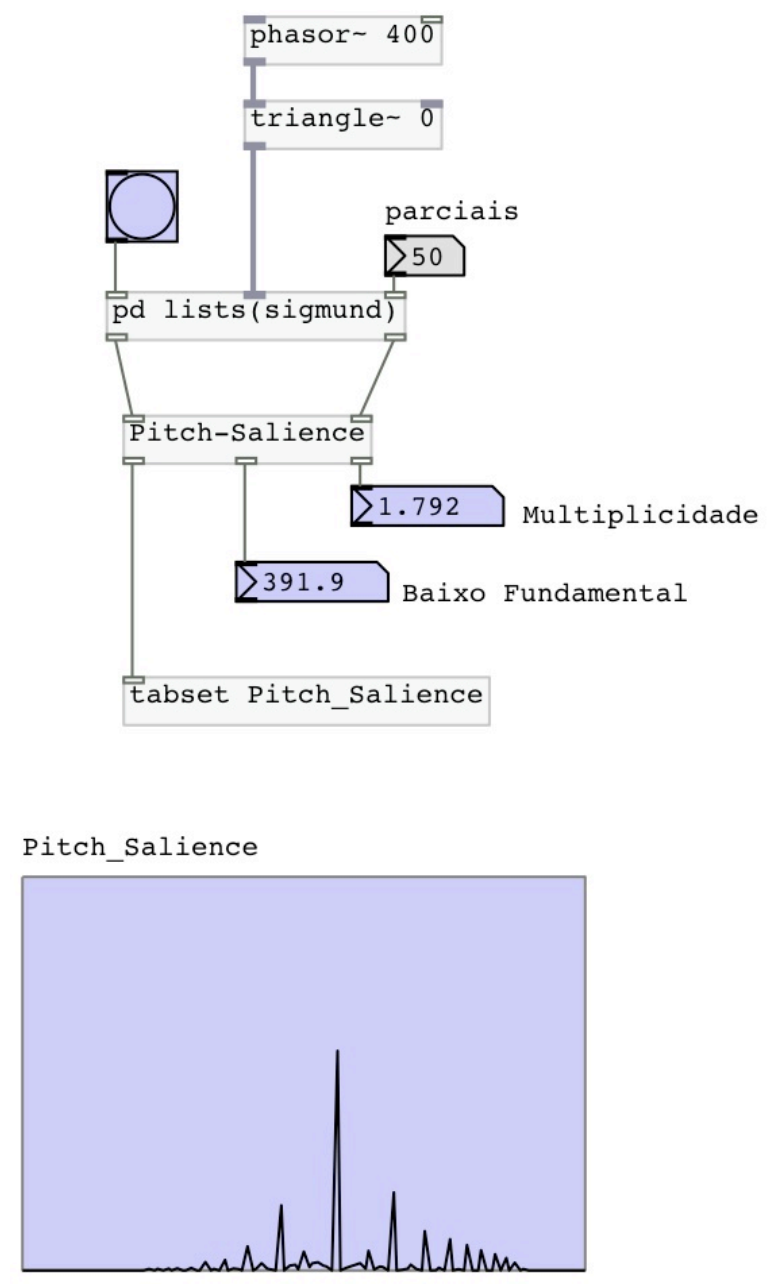

Figura 38 - Objeto de Saliência de Altura.

O Baixo Fundamental acusado, como esperado, está próximo da fundamental. Mas, devido à resolução de análise estar de acordo com o sistema temperado, há uma diferença de quase 8 Hertz, que resulta em uma diferença em torno de 35 cents. Caso a resolução da análise estivesse em sextos de tom (36 intervalos por oitava, que correspondem a passos de $33.333 \ldots$ cents), a diferença seria bem menor. 
O Baixo Fundamental corresponde ao maior ponto da tabela e pode corresponder à fundamental, como neste exemplo, ou também indicar uma fundamental ausente de um espectro sonoro como previsto pela teoria e modelo de Altura virtual. No caso de um acorde ou combinação de sonoridades distintas, o modelo pode indicar qual dos tons corresponde à Fundamental do Acorde, mas também pode indicar um tom ausente.

Outras aplicações são interessantes com o perfil de saliência além de apenas acusarmos o tom mais saliente como Baixo Fundamental. Uma ideia explorada foi a de extrair os picos mais proeminentes através de um processo como a mediana do espectro. Assim, temos uma coleção de tons mais importantes em uma sonoridade complexa. Maiores desdobramentos serão dados na sequência.

\subsubsection{Objeto [Pitch-Commonality]}

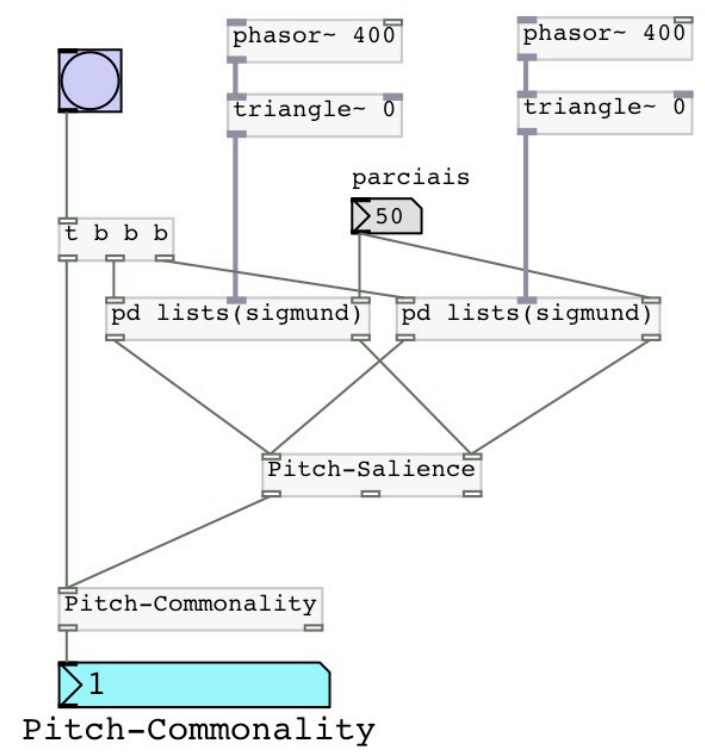

Figura 39 - Objeto de Comonalidade de Altura comparando duas sonoridades iguais.

Diferentemente dos objetos anteriores, não especificamos a resolução de frequências, pois o objeto [Pitch-Commonality] apenas recebe as listas de valores. Não obstante, é necessário que as listas sejam de um mesmo tamanho. Por esse motivo, o objeto faz uma checagem e acusa um erro quando recebe listas de tamanhos diferentes. Vejamos a figura 39, que, diferentemente da figura 35, apresenta um resultado de exatamente 1 , pois tratam-se de duas sonoridades iguais.

Depois de receber pelo menos duas listas, o objeto pode calcular a 
Comonalidade de Altura após receber uma mensagem bang - que também reseta (ou "limpa") o objeto para que comece a receber novas listas. Os vários perfís são recebidos por essa única entrada. Aqui já temos uma diferença estrutural do primeiro exemplo apresentado, na forma implementada em um patch de Pure Data, em que havia duas entradas e a capacidade máxima era de comparar apenas duas sonoridades. Outro detalhe diferente é que a figura a seguir adota apenas um objeto [PitchSalience].

Quando comparamos mais de duas sonoridades, o resultado não é mais apenas um único valor, mas sim um valor para cada combinação entre os Perfís de Saliência. De tal maneira, a comparação de quatro sonoridades $(1,2,3,4)$ nos retorna seis

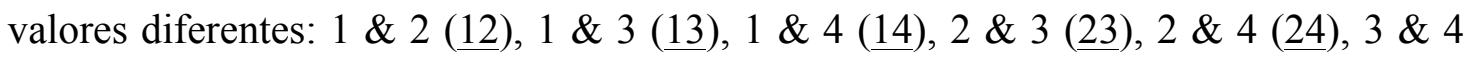
(34), que são dados por uma matriz na seguinte forma:

$\begin{array}{llll}11 & \underline{12} & \underline{13} & \underline{14} \\ 21 & 22 & \underline{23} & \underline{24} \\ 31 & 32 & 33 & \underline{34} \\ 41 & 42 & 43 & 44\end{array}$

No exemplo dado, os números sublinhados correspondem aos seis valores descritos. Os números em negrito indicam comparações de uma sonoridade com ela mesma. Logo, os valores são sempre iguais a 1 e podem ser desconsiderados. Esses números também traçam uma linha diagonal que divide a matriz em duas porções iguais, sendo que os valores restantes também possuem o mesmo valor dependendo da combinação de números $(32=23,21=12$, e assim por diante). Cada linha representa então todas as comparações com uma sonoridade (a primeira linha contém as comparações com a primeira sonoridade, assim por diante até a quarta linha). Nesse exemplo, cada linha deixa de fora dois valores que, obviamente, não contém a sonoridade em questão.

Mas é possível também armazenar três dessas quatro sonoridades, e comparar uma quarta entrada de dados com esses dados armazenados, o que nos dá apenas três valores e corresponde à ultima linha da matriz, ignorando o último valor igual a 1 . Essa estrutura em que o objeto [Pitch-Commonality] está completamente independente do objeto que gera seus dados de entrada, [Pitch-Salience], traz esse tipo de vantagem. Veremos mais dessas capacidades avançadas no próximo subitem. 


\subsubsection{Comparação Avançada com o Objeto [Pitch-Commonality]}

A separação da geração dos dados com o objeto [Pitch-Salience] e a comparação deles com o objeto [Pitch-Commonality] permite, por exemplo, a importação de um banco de dados com vários Perfis de Saliência de Altura previamente armazenados.

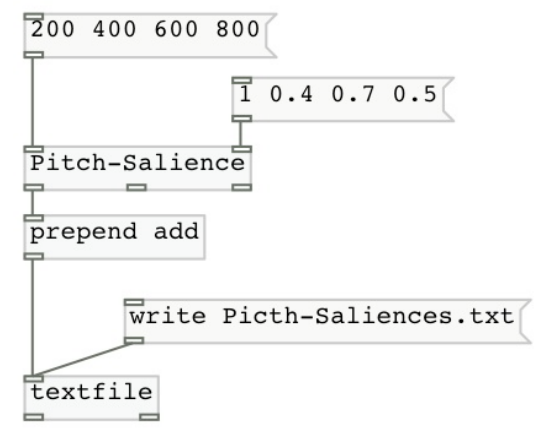

Figura 40 - Gerar um banco de dados com o objeto [textfile].

Essas análises prévias, certamente, necessitam do objeto [Pitch-Salience] para serem geradas. Mas, uma vez que esses foram armazenados em um arquivo, podemos nos poupar de seu processamento e usar o objeto [Pitch-Commonality] apenas como um objeto comparador.

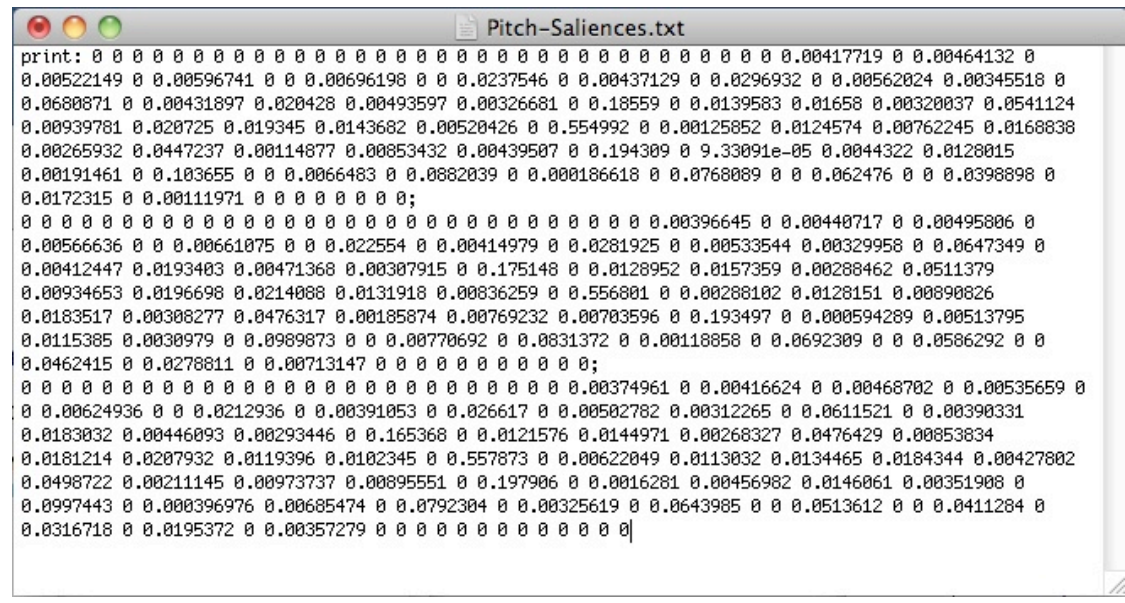

Figura 41 - Exemplo de arquivo de texto armazenando 3 Perfis de Saliência.

O armazenamento dos dados consiste em simplesmente guardar os valores da tabela em um formato de lista, do mesmo modo que é a saída do objeto [PitchSalience]. Para separar uma lista de outra próxima, basta inserir ponto-e-vírgula e colocar a outra lista abaixo. Essa é a forma em que os objetos [textfile] e [msgfile] 
geram e leem arquivos de texto no Pure Data, o que lhes permite serem usados para gerar e ler os bancos de dados. Veja as figuras 40 a 42.

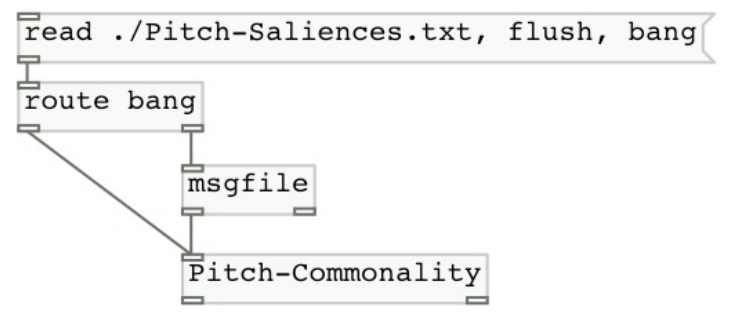

Figura 42- Exemplo de como importar e rodar, com o objeto [msgfile], os dados no objeto [Pitch-Commonality].

O objeto [Pitch-Commonality] é capaz de receber listas e armazenar uma série de Perfis de Saliência. Para que o objeto comece e pare de armazenar, é preciso enviar o comando "store" seguido de 1 (para iniciar a armazenar) ou 0 (para parar de armazenar). O armazenamento pode ser reiniciado após ser interrompido, o que faz que novos dados sejam armazenados junto aos anteriores. A forma de apagar todos os dados armazenados é com o comando "clear". Veja a figura 43.

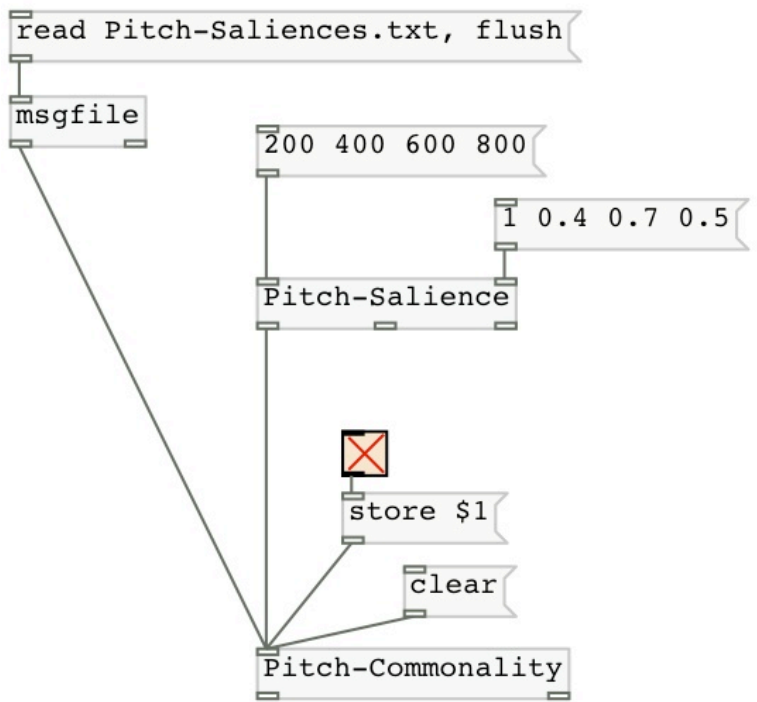

Figura 43 - Armazenamento de dados no objeto [Pitch-Commonality].

Com essa estrutura, mesmo com um número de sonoridades previamente armazenadas, o objeto continua operando igualmente: novas entradas que não serão armazenadas continuam sendo carregadas dentro do objeto e somadas às que estiverem armazenadas. Após um comando "bang", o objeto faz o seu cálculo com todos os 
Perfis de Saliência de Altura carregados e elimina os que não foram marcados para ficarem armazenados. Logo, ainda permanecem os que foram devidamente armazenados, os quais só podem ser apagados de fato com o comando "clear".

Por fim, como mencionado anteriormente, também podemos comparar um dado de entrada diretamente com outros armazenados no objeto [Pitch-Commonality]. Para tal, temos o comando "compare", seguido do valor 1 para ligar e 0 para desligar esse modo. A saída de resultados é uma lista com o valor de comparação entre o dado de entrada com cada Perfil de Saliência previamente salvos, respeitando a ordem em que foram armazenados. Desse modo, a cada nova entrada de um Perfil de Saliência, um resultado de saída é calculado. Assim, não precisamos mais enviar uma mensagem “bang”. Vide Figura 44.

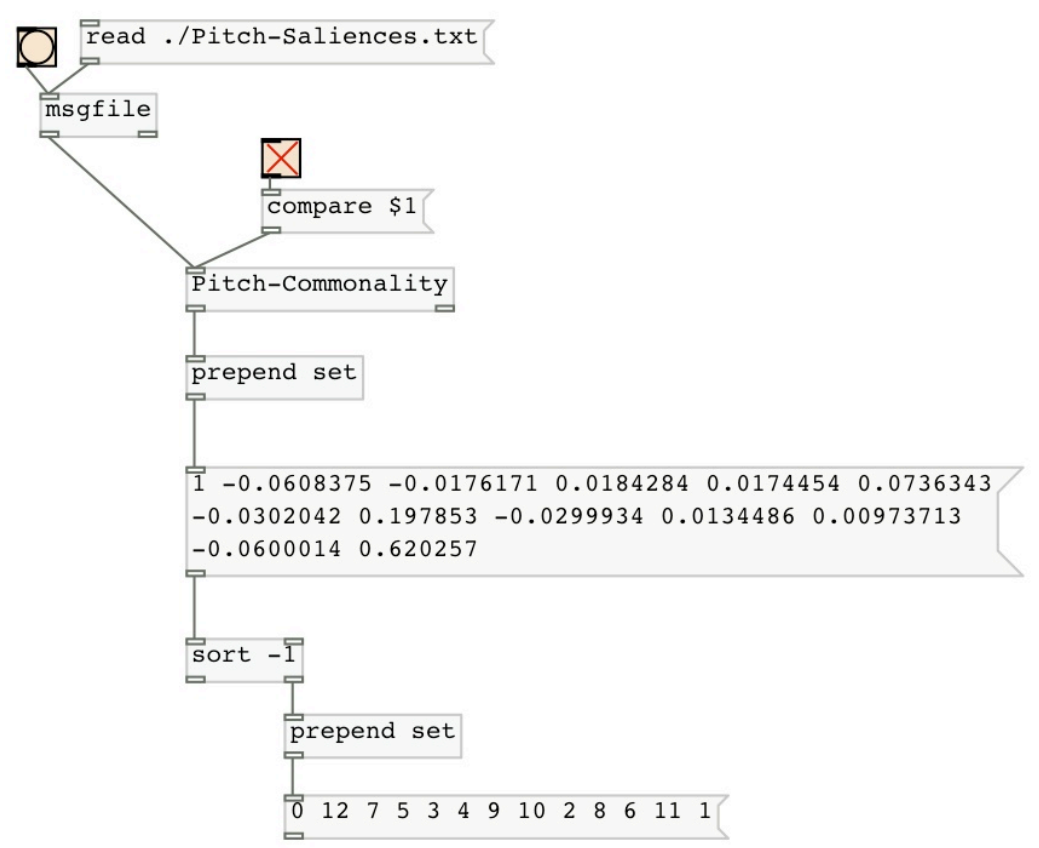

Figura 44 - Comparação da fundamental de uma escala com todos os intervalos cromáticos de uma oitava.

A figura 44 mostra a comparação de um dado de entrada com treze Perfis de Saliência previamente armazenados no objeto [Pitch-Commonality]. As treze sonoridades são, como já de praxe, ondas dente-de-serra. Elas representam uma escala de alturas com esse mesmo formato de onda e foram armazenadas em uma ordem ascendente. A escala é o sistema igualmente temperado, que vai de $440 \mathrm{~Hz}$ (Lá central) até uma oitava acima, ou seja, $880 \mathrm{~Hz}$. O dado de entrada é justamente o primeiro Perfil de Saliência de Altura, de 440 Hz. 
Os doze resultados nos dão uma relação de Comonalidade de Altura entre essa sonoridade e treze intervalos harmônicos (do uníssono à oitava). Usamos o objeto [sort] para reordenar os resultados de forma descendente, e seu outlet direito nos dá os índices ordenados do maior ao menor valor de Comonalidade de Altura. Os índices muito bem representam os intervalos harmônicos dados em semitons, de 0 (uníssono) a 12 (oitava).

Tabela 8. Comonalidade de Altura em ordem decrescente dos intervalos

Intervalos

Musicais

\section{Uníssono;}

Oitava;

Quinta;

Quarta;

Terça Menor;

Terça Maior;

Sexta Maior;

Sétima Menor;

Segunda Maior;

Sexta Menor;

Trítono;

Sétima Maior;

Segunda Menor.
Comonalidade

De Altura

1

0.620257

0.197853

0.0736343

0.0184284

0.0174454

0.0134486

0.00973713

$-0.0176171$

$-0.0299934$

$-0.0302042$

$-0.0600014$

$-0.0608375$

Na tabela 8, temos os intervalos, do mais comum ao menos comum, dados por seu nome e o valor da medida comparativa dada pelo objeto. Veremos mais desse tipo de análise de intervalos musicais quando discutirmos Curvas de Dissonância, onde também figuram análises dos objeto [tonalness] e [roughness].

\subsection{Harmonicidade}

Por fim, apresentamos uma implementação do modelo de Barlow para seu conceito e método de medir a Harmonicidade de um intervalo musical. Trata-se de algo extra e anexo ao foco central da pesquisa, pois o método em si é arbitrário e não envolve nenhum estudo psicoacústico. $\mathrm{Na}$ última parte deste texto, entretanto, trazemos algumas considerações sobre a adoção de certas arbitrariedades, ou melhor, de um empirismo em relação a esse tipo de pesquisa e objetivos composicionais.

O modelo de Harmonicidade se baseia em um cálculo da "indigeribilidade" dos números inteiros que formam a fração de um intervalo musical. Portanto, se a entrada 
de intervalos é em cents ou uma razão, ela precisa ser convertida para uma fração. As duas entradas do objeto [harmonicity] correspondem aos dois números da fração.

Segundo Barlow (1987), a indigeribilidade de um número inteiro é uma medida de quão psicologicamente digerível é um número de acordo com seus fatores primos. Logo, outro passo necessário consiste em fatorar os números da fração. Barlow utiliza um exemplo para nos dar a ideia de indigeribilidade: em quantos pedaços seria mais fácil cortar um bolo? A sequência em ordem crescente de dificuldade dos números $1 \mathrm{a}$ 16 seria: $1,2,4,3,8,6,16,12,9,5,10,15,7,14,11,13$. A tabela 9 nos dá os números de 1 a 16 e seus respectivos valores de indigeribilidade que, na ordem crescente, correspondem à lista anterior. Antes, trazemos as fórmulas da indigeribilidade de um número $\mathrm{N}$ e a harmonicidade de uma fração $(\mathrm{P}, \mathrm{Q})$.

$$
\begin{aligned}
& \xi(N)=2 \sum_{\mathrm{r}=1}^{\mathrm{r}=\infty}\left\{\mathrm{n}_{\mathrm{r}}\left(\mathrm{p}_{\mathrm{r}}-1\right)^{2} / \mathrm{p}_{\mathrm{r}}\right\} \\
& \text { onde } \left.N=\prod \mathrm{p}_{\mathrm{r}} \mathrm{n}_{\mathrm{r}} \text { (fatores primos de um inteiro } N\right) \\
& \begin{aligned}
& \mathrm{H}(\mathrm{P}, \mathrm{Q})=\operatorname{sgn}(\xi(\mathrm{Q})-\xi(\mathrm{P})) /(\xi(\mathrm{P})+\xi(\mathrm{Q})) \\
& \text { onde sgn }=-1 \text { caso negativo, hcf é o maior fator comum de } a \text { e } b, 2 \\
& \text { e } \xi(\mathrm{x}) \text { é a indigeribilidade de um número } \mathrm{x} .
\end{aligned}
\end{aligned}
$$

Tabela 9. Indigeribilidades dos números 1 a 16.

\begin{tabular}{cl}
$N$ & \multicolumn{1}{c}{$\xi(N)$} \\
\hline 1 & 0,000000 \\
2 & 1,000000 \\
3 & 2,666667 \\
4 & 2,000000 \\
5 & 6,400000 \\
6 & 3,666667 \\
7 & 10,285714 \\
8 & 3,000000 \\
9 & 5,333333 \\
10 & 7,400000 \\
11 & 18,181818 \\
12 & 4,666667 \\
13 & 22,153846 \\
14 & 11,285714 \\
15 & 9,066667 \\
16 & 4,000000
\end{tabular}


A harmonicidade também pode ser medida entre as relações dos componentes espectrais de uma sonoridade como o próprio autor já implementou. Barlow também adotou esse modelo para medir a harmonicidade de diversas escalas e sistemas de afinações. Mais detalhes da teoria de Barlow encontram-se em seus textos (1980, 1987, 2008).

A figura 45 usa o objeto [harmonicity] para calcular a harmonicidade de intervalos musicais entre as razões de 1.4 (um trítono dado pela fração [7:5], ou 582.5 cents) a 1.6 (uma Sexta Menor dada pela fração [8:5], ou 813.7 cents), sendo que o ponto médio é uma quinta justa (1.5, ou [3:2], ou ainda 701.9 cents). Primeiramente, convertemos os números em frações, para depois inseri-las no objeto. O gráfico é análogo ao da figura 13, porém está invertido. Assim, de baixo para cima, medimos a Dissonância e, de cima para baixo, a Consonância ou Harmonicidade. Os picos de harmonicidade correspondem à, seguido da sexta menor [8:5] e trítono [7:5].

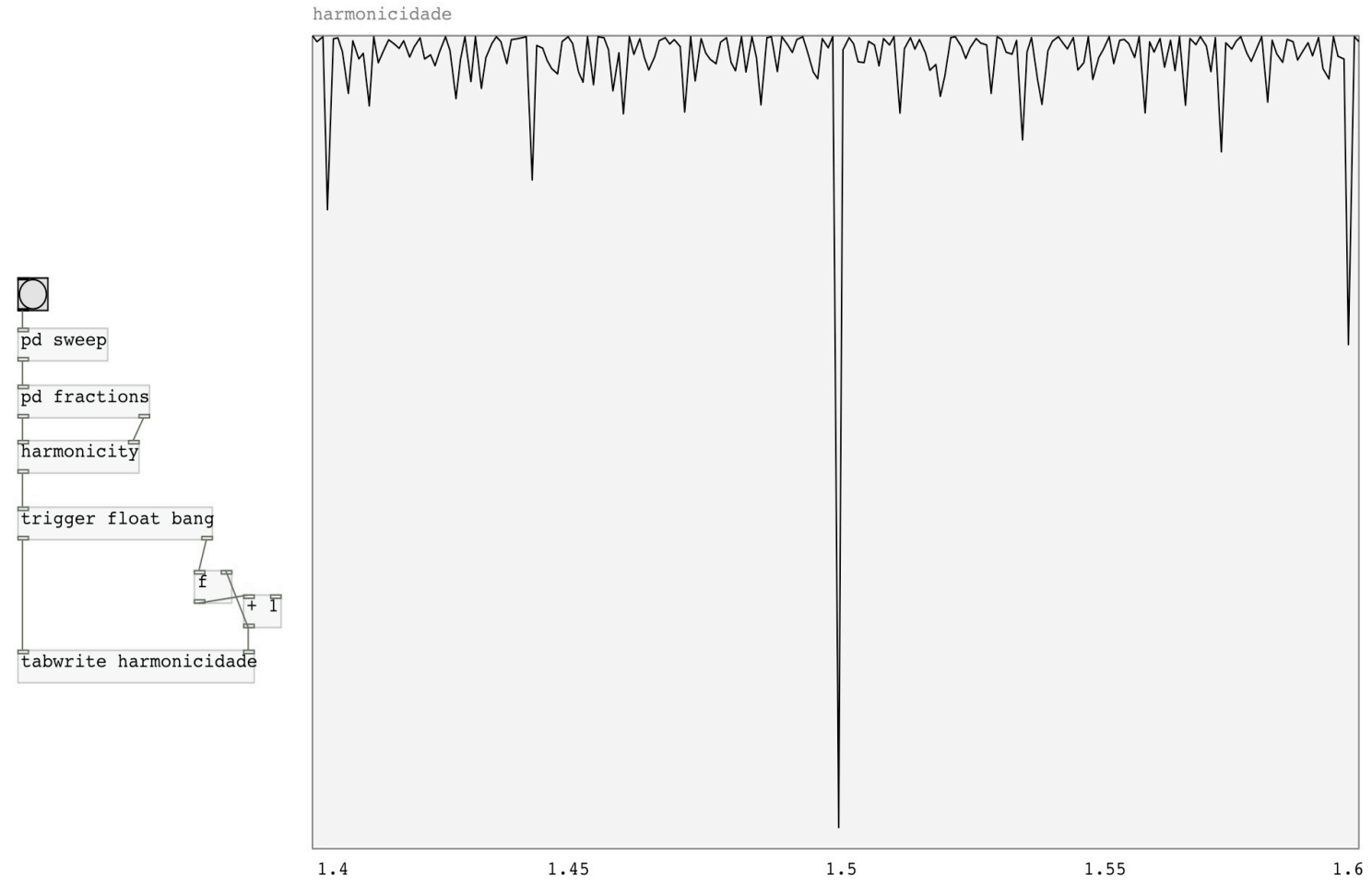

Figura 45 - Curva de Harmonicidade. 


\section{Capítulo 10) Patches Desenvolvidos}

A partir dos modelos psicoacústicos implementados (que em si já podem ser utilizados como descritores e ferramentas úteis), desenvolvemos uma série de patches que visam melhor explorar uma potencialidade criativa em tempo real. A aplicação que mais tem sido usada a partir desses princípios é a técnica de Sethares (1999), que consiste em gerar escalas a partir de espectros e também manipular um espectro para que fique de acordo com uma escala. Além de ferramentas dessa ordem, temos também outras ferramentas que se voltam, principalmente, a uma manipulação de conteúdo espectral em geral e mudança de alturas.

A manipulação espectral é um modo de interferir diretamente na percepção de altura e qualidade tonal. Esse procedimento possui um impacto em praticamente todos os atributos perceptivos estudados. Já a mudança de altura (Pitch Shifting) é um princípio básico para manipulação de intervalos musicais, escalas e relações harmônicas - um processo essencial das possíveis aplicações criativas.

Deixamos de lado, entretanto, o desenvolvimento de ferramentas dedicadas a princípios de descrição sonora, relacionados a exemplos dados no início desta segunda parte e nos concentramos apenas em Curvas de Dissonância como descritores de intervalos musicais e suas aplicações. Um fator que contribuiu para não termos explorado muito esse aspecto é que o problema de descrição de dissonância ainda não está bem resolvido.

\section{1 - Separação de Ruído de Fundo e Qualidade Tonal}

Como um único oscilador gera dados de análise distribuídos por boa parte do espectro (vide figura 21), um som complexo gera ainda mais. Entretanto, é fácil detectar os picos de parciais, os quais representam os componentes espectrais mais proeminentes e a qualidade tonal de uma sonoridade. A necessidade de separar qualidades tonais em uma análise espectral permite, em especial, uma manipulação direta nessa porção do espectro que diz respeito aos parciais mais proeminentes.

Outras informações importantes para o timbre se encontram diluídas em uma distribuição menor de energia no espectro, de forma menos uniforme e mais "caótica". Tal conteúdo espectral pode ser, por exemplo, a fricção do arco em um instrumento de corda, ou o som presente em deslocamentos de ar nos instrumentos de sopro. 
Em alguns casos há até mesmo ruídos indesejados que gostaríamos de eliminar, o que é possível com procedimentos do tipo noise gate, ou mesmo com redução de ruído. Porém, não estamos preocupados com esse tipo de procedimento de eliminação, mas sim com a separação e conseguinte junção entre ruído de fundo e picos mais proeminentes.

Em relação a isso, há um exemplo que se encontra presente nas distribuições de Pure Data chamado Sheeps from Goats (patch $\mathrm{n}^{0}$ I09); trata-se de um dos exemplos práticos do livro de Miller Puckette (2006), que figuram como exemplos de áudio em qualquer distribuição do Pd. Desse exemplo, foi elaborada uma adaptação para que pudéssemos dividir um fluxo de sinal em dois canais e balancear a saída para ambos, em que um lado tende ao ruído, enquanto o outro tende à qualidade tonal. O processo se baseia em uma checagem de coerência entre as fases de pontos de frequência vizinhos.

Visto que um pico de um componente espectral pode estar disposto em mais de um ponto de frequência da análise, essa técnica é capaz de acusar um grau de coerência como patamar de divisão. Desse modo, se o grau de exigência for grande, apenas picos muito evidentes serão considerados, enquanto o resto seria ruído. A soma de ambos canais, independentemente de qual patamar foi feita a divisão do sinal, reconstrói com ótima fidelidade a entrada original.

Uma segunda técnica adotada foi inspirada no trabalho de Sethares et. al (2009), que apresenta algumas ferramentas com funcionalidades iguais às das desenvolvidas nesta pesquisa. Esse processo consiste em definir, por meio de medianas, valores de chão (ou um patamar) para vários trechos do espectro e dividir o que estaria abaixo (considerado como ruído de fundo) do que estaria acima (considerado como os parciais mais proeminentes). Um segundo parâmetro é capaz de elevar esse chão, ao multiplicá-lo por um valor constante. Assim, conseguimos interferir (aumentar ou diminuir este limiar) no processo de filtragem. Da mesma maneira, somar as duas saídas divididas do sinal acaba reconstituindo com fidelidade a entrada de sinal.

A figura 46 mostra uma implementação com essas duas técnicas, ambas filtrando a mesma entrada de sinal, que é uma flauta tocando uma nota de modo estático. O patamar de corte, na segunda técnica, foi calculado em trechos de 32 amostras - esse número é conveniente porque as janelas de FFT são sempre múltiplos de 32, uma vez que os algoritmos de FFT necessitam que as janelas de análise sejam 
iguais a uma potência de 2 .

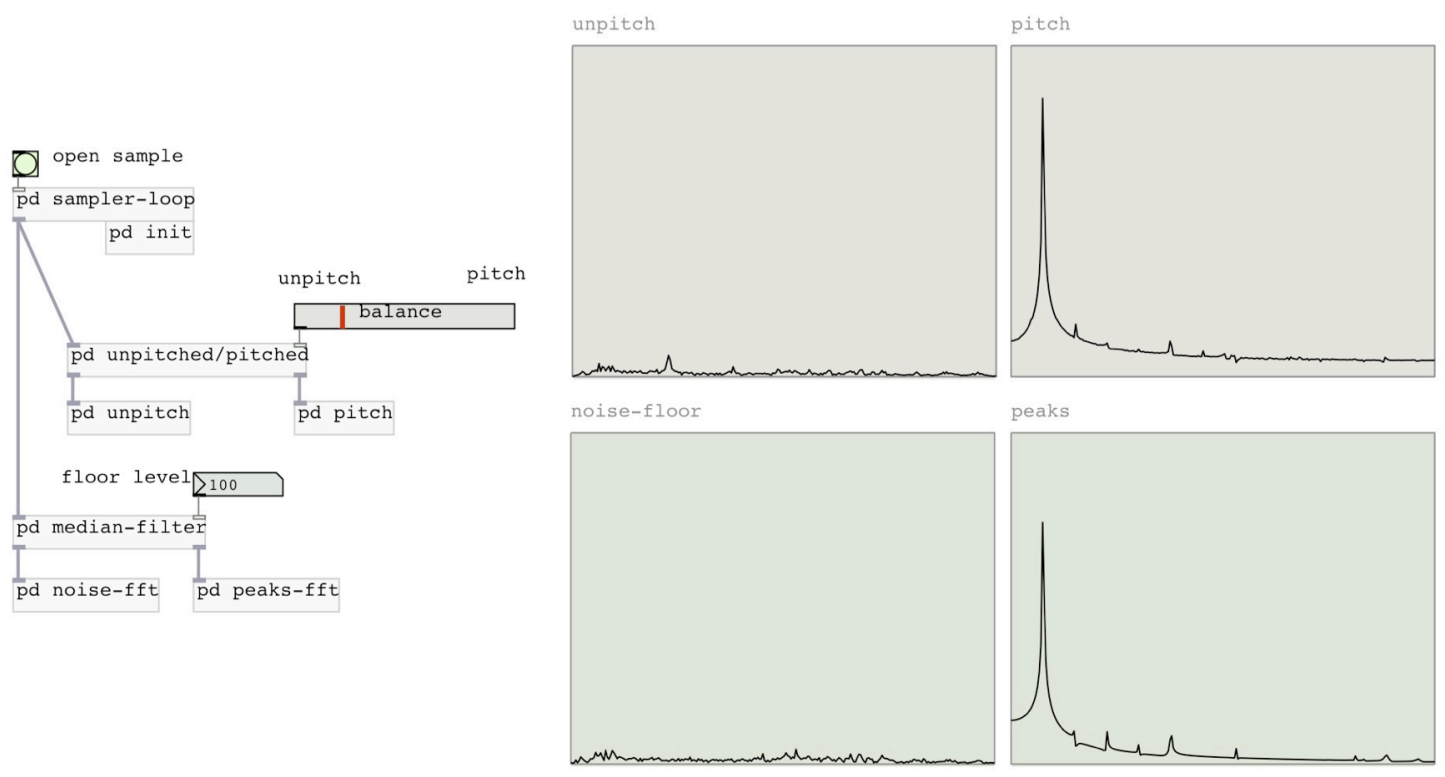

Figura 46 - Patches de separação de ruído e conteúdo tonal.

A figura acima demonstra e compara as duas técnicas, obtendo resultados semelhantes auditivamente, também constatados nos gráficos de análise. Os gráficos são os valores de amplitude dos sinais divididos, sendo a análise da esquerda a extração de ruído, e a da direita o isolamento de picos mais proeminentes.

A primeira técnica descrita, baseada em coerência de fases, corresponde à parte de cima da figura, e ao subpatch [unpitched/pitched]. O slider de balanço indica que a divisão pende mais para a saída do sinal "unpitched", que corresponde à saída esquerda do subpatch. No processo de filtragem por meio de uma mediana no espectro, o parâmetro "noise floor" indica um fator relativamente alto de elevação do patamar de filtragem, o que também eleva a quantidade de sinal que vem da saída esquerda do subpatch.

\section{2 - Ressíntese via Banco de Osciladores}

Um patch de ressíntese foi implementado com informações extraídas com o objeto [sigmund ]. O processo em si não é muito complicado, uma vez que o objeto já foi estruturado para alimentar um banco de osciladores. Em compensação, nosso interesse é poder manipular esses dados em outras instâncias, tendo a capacidade de controles avançados e independentes de manipulação espectral. Por isso, desenvolvemos outros exemplos baseados nesse patch.

Uma primeira utilidade da ressíntese é que, como usamos o objeto [sigmund ] 
para gerar listas de frequência e amplitude representando uma entrada sonora, nada melhor do que uma reconstrução desse sinal via banco de osciladores, para que possamos escutar o resultado sonoro gerado pela informação dessas listas e, assim, julgar se a representação pelas listas é fiel e correspondente ao sinal de entrada.
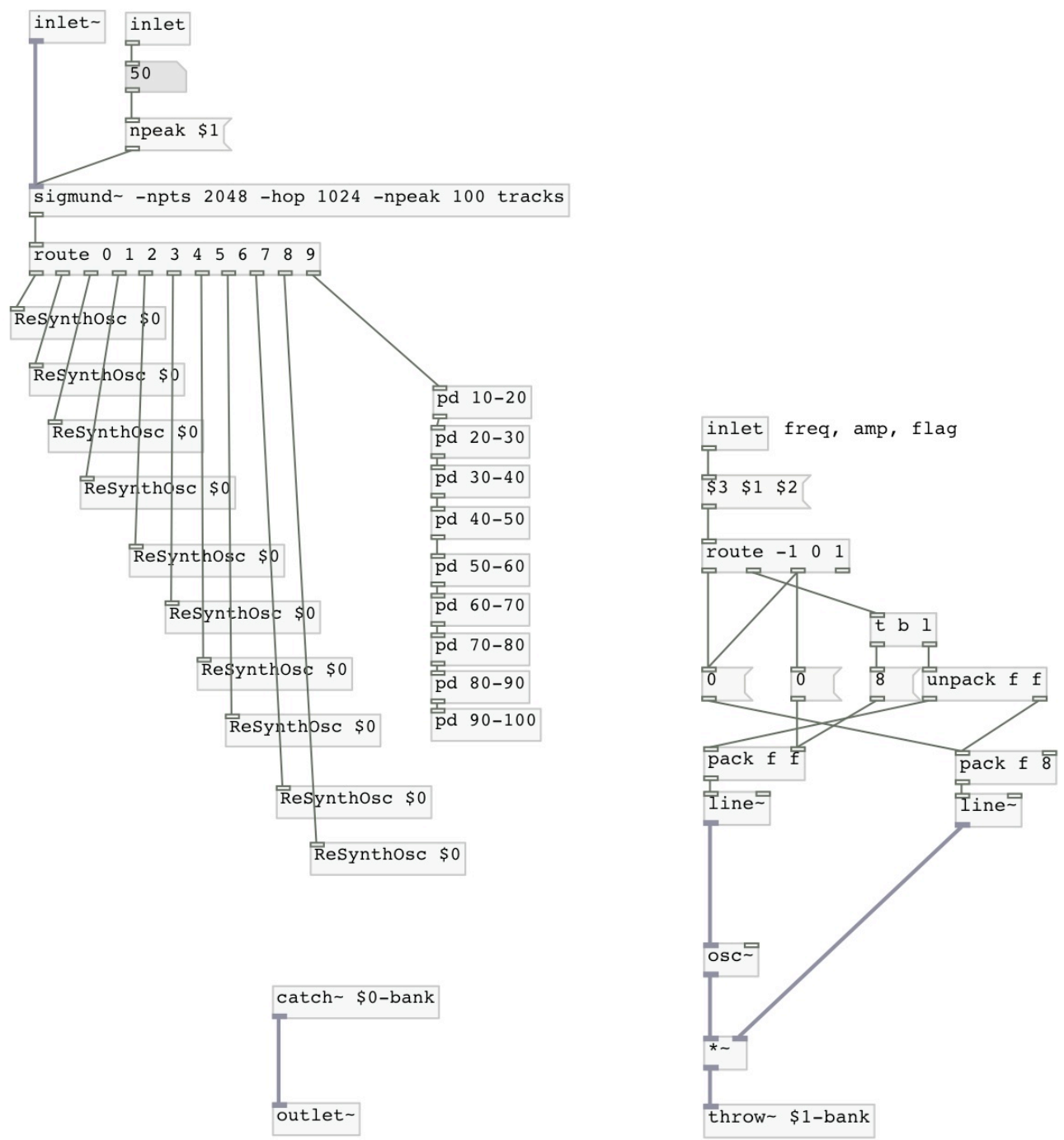

Figura 47 - Implementação de um banco de 100 osciladores para ressíntese.

A figura acima nos mostra os dados do [sigmund ] sendo roteados para várias instâncias de uma abstração que consiste em um oscilador. Os 10 primeiros osciladores se encontram logo abaixo, e o roteamento para os restantes é feito em subpatches, totalizando um número de 100 osciladores. À direita da figura, temos a implementação de uma das instâncias do oscilador, que recebe valores de frequência, amplitude e uma marca para informar se é uma faixa contínua, vazia, ou nova. 


\section{3 - Mudança de Altura (Pitch Shifting)}

Técnicas de mudança de altura são peças importantes nesta pesquisa, pois as ferramentas desenvolvidas buscam aplicações práticas em afinação, onde uma reafinação automática pode mudar e manipular escalas e sistemas de afinação. Outra aplicação é na geração de harmonias, ou díades.

Um estudo detalhado ou um desenvolvimento aprimorado em técnicas de manipulação de altura é um problema complicado e paralelo. Um procedimento de mudança de altura altamente eficaz para diversos casos distintos ainda está para ser desenvolvido (Parviainen 2006). O maior empecilho claramente não é falta de interesse, mas restrições puramente matemáticas de cada técnica distinta, o que significa que as possibilidades atuais já foram relativamente esgotadas. Logo, os últimos avanços têm sido em melhorias de métodos já existentes, em que há um aprimoramento da qualidade de análise dos dados.

Um primeiro problema que encontramos é que um simples deslocamento geral do conteúdo espectral, para o grave ou agudo, exerce uma evidente influência na mudança de percepção de altura, porém distorce outros atributos perceptivos do som original. A respeito disso, testamos as técnicas de extração de picos e separação de ruído de fundo, para que o tratamento de mudança de altura ocorresse apenas na porção referente à qualidade tonal do som.

Foram testados vários métodos já implementados em Pure Data, como o próprio pitch shifter desenvolvido por Miller Puckette (2006), que também faz parte dos exemplos de áudio que acompanham a distribuição do programa (exemplo G09). Um trabalho interessante encontrado é um objeto externo baseado em PSOLA, implementado a partir de uma biblioteca desenvolvida por Olli Parviainen ${ }^{30}$. Seu nome é [soundtouch] e também permite compressão e expansão de tempo.

Em todo caso, preferimos nos basear em uma implementação em patch de Pure Data da técnica de Phase Vocoder desenvolvida por Miller Puckette (2006), que permite tanto a mudança de altura quanto o controle independente de compressão/expansão de tempo. Um critério forte na decisão sobre qual ferramenta optar foi que não deveríamos buscar objetos externos ao Pure Data, a não ser que seu resultado promovesse uma diferença concreta muito forte, de forma que, se abríssemos mão dela, teríamos uma perda lastimável.

$30 \quad$ Disponível em: $<$ http://www.surina.net/soundtouch/>. 
Nesse sentido, a qualidade do Phase Vocoder implementado no Pd não deixa tanto a desejar. Além disso, apesar de serem alheias, a compressão e expansão de tempo também são de interesse nos módulos de aplicação criativa desenvolvidos durante a pesquisa. Assim, aplicamos e adaptamos sua estrutura em implementações próprias de mudança de Altura. Além do Phase Vocoder, testamos também um patch tendo como base a ressíntese por meio de um banco de osciladores. Apresentamos a seguir esses dois métodos explorados para mudança de altura e, na sequência, um exemplo da aplicação delas como um "harmonizador".

\subsubsection{Pitch Shifting via Ressíntese}

No momento em que temos um banco de osciladores reconstruindo um sinal de áudio, é simples e trivial operar uma mudança de altura. Basta apenas alterar a frequência do oscilador. Inserimos essa propriedade no patch de ressíntese apresentado anteriormente e acoplamos também um módulo que separa o ruído de fundo para ser acrescentado novamente após o processamento. Dentre os testes com a separação de ruído, a técnica de separação com a mediana do espectro surtiu efeitos mais positivos, em especial para transposições ao grave.

$\mathrm{O}$ aspecto mais relevante do uso dessa técnica com ressíntese é que somos capazes, também, de outras manipulações desenvolvidas durante a pesquisa, em especial o mapeamento espectral. A separação de ruído de fundo não só pode melhorar a qualidade sonora, como também permite que o processamento de ressíntese seja feito com um número menor de osciladores, o que poupa em muito o processamento da CPU.

\subsubsection{Phase Vocoder}

O Phase Vocoder foi originalmente concebido por Flanagan e Golden (1966). Seu conceito, em parte, possui relação com o anteriormente conhecido Vocoder, desenvolvido por Dudley (1939). O termo Vocoder vem de uma contração de VOice enCODER e nasce como fruto de pesquisas em análise e síntese da fala para aplicações em telecomunicação, mas obteve uma aplicação em música por sua estrutura de filtros. Hoje em dia, podemos implementar o Vocoder com dados de uma FFT, que podem ter milhares de bandas de frequência usadas como filtros.

O "Vocoder Clássico" também pode ser chamado de Subband Vocoder, ou Channel Vocoder. Channel e Subband referem-se a bandas de frequência, como em 
equalizadores e filtros. O número de bandas de um Vocoder Clássico variava de $8 \mathrm{a}$ 30. Uma aplicação com o Vocoder em música é a Síntese Cruzada, que também será apresentada nesta pesquisa.

Enquanto o Vocoder lidava apenas com informação de amplitudes em dadas faixas de frequência, o Phase Vocoder apareceu como uma expansão que também computava a fase inicial de cada faixa de frequência. Comparado ao Vocoder, o Phase Vocoder possuía mais bandas, pois só assim fazia sentido computar as fases iniciais, uma vez que a intenção era uma melhor resolução de frequências. Atualmente, o Phase Vocoder também é um software normalmente implementado sobre Análises de FFT, que podem ter uma resolução de milhares de bandas em tempo real e retornam a Amplitude e Fase Inicial de cada banda.

Na prática, o Phase Vocoder pouco tem a ver com codificação de fala e até mesmo com a técnica de Síntese Cruzada. Seu uso era limitado a experts em DSP, mas tem se tornado mais difundido com o atual avanço da computação em geral e aplicado amplamente em música desde a década de 1990. Um exemplo clássico da aplicação de Phase Vocoder em Música Computacional é a peça VOX 5 de Trevor Wishart, em manipulações de voz humana (1988).

Quanto às aplicações, ainda na década de 1960, constatou-se que era possível reconstituir o som original da análise de forma muito fiel após alterações de tempo, ou frequência. Por isso, quando falamos de Phase Vocoder, estamos falando, normalmente, de uma técnica de comprimir ou expandir o tempo de um som (Time Stretch/Compress), alterar sua Altura (Pitch Shift), ou ainda ambos, de forma independente.

O elemento-chave da técnica é se valer da informação de fase inicial para manter uma coerência na reconstrução de frequência. Vimos que diferenças de fase inicial entre duas janelas consecutivas de análise aferem com maior precisão os valores de frequência de uma análise de FFT, como é o caso de rotinas internas do objeto [sigmund ]. Da mesma maneira que usamos o objeto [sigmund ] para alimentar um banco de osciladores, uma estrutura comum e original do Phase Vocoder também consiste exatamente em uma análise de dados, manipulação de frequência e tempo desses dados e uma ressíntese por meio de um banco de osciladores. Dessa forma, o Pitch Shifter desenvolvido com o [sigmund ] não está longe de ser uma espécie de Phase Vocoder.

Aliás, o trabalho de Sethares et al (2009) adota um banco de osciladores com 
referencia direta à técnica de Phase Vocoder. Por isso, em um conceito mais amplo, é possível relacionar o Phase Vocoder a técnicas avançadas de manipulações espectrais quaisquer, para depois ressintetizar com um banco de osciladores.

$\mathrm{Na}$ implementação de Phase Vocoder, apenas com dados de uma FFT, a transformada inversa substitui o que seria o estágio de ressíntese por meio de osciladores, uma vez que o sinal é reconstruído de um modo análogo à Síntese Aditiva. Porém, lidar com dados brutos de FFT é um processo mais limitado. Em relação a um banco de osciladores, essa estrutura baseada em FFT restringe bastante as diversas manipulações possíveis, já que com osciladores independentes podemos também processá-los de forma independente.

A implementação em FFT busca simplificar o processo, mas ainda permite, com ótima qualidade, a mudança de altura e tempo do sinal como um todo. O Phase Vocoder implementado por Miller Puckette em um patch de $\mathrm{Pd}$ - mais um exemplo de seu livro (2006) - é uma implementação baseada somente em FFT e foi tomada como base para adaptações diversas durante o desenvolvimento desta pesquisa. Em um momento temos, inclusive, a junção do Phase Vocoder para manipulação de altura com um módulo de ressíntese para operar outras manipulações espectrais.

A FFT possui a vantagem de ter uma implementação mais simples e com menos gasto computacional. A análise de FFT precisa ser feita em duas janelas seguidas, justamente para computar a diferença de Fase inicial. Chamemos essas duas janelas de "traseira" e "dianteira" (ou "atual" e "última"). A "dianteira" corresponde ao ponto real de leitura de um sinal, e a "traseira" está ali só para computar a diferença de fase com um momento anterior. O passo entre uma janela e outra (hop) depende do tamanho da janela (ou "bloco") e o número de overlaps.

A reconstrução da fase inicial se dá em um processo que se chama "Acúmulo de Fase". Na figura 48, o diagrama ilustra que, nesse processo, a diferença de fase é somada com um resultado de fase anterior, que no desenho está indicado como "phase accum" (de acúmulo de fase). Essa soma gera a informação de fase final a ser levada para a FFT inversa e também inserida novamente para o acúmulo de fase na próxima rodada. Veremos com mais detalhes como esse processo é capaz de manter uma coerência de fase, o que ajuda na reconstrução do sinal. Sem esse procedimento, ainda é possível conseguir mudança de altura e tempo independentemente, mas com pouquíssima qualidade e algumas distorções pela descontinuidade de fase. 


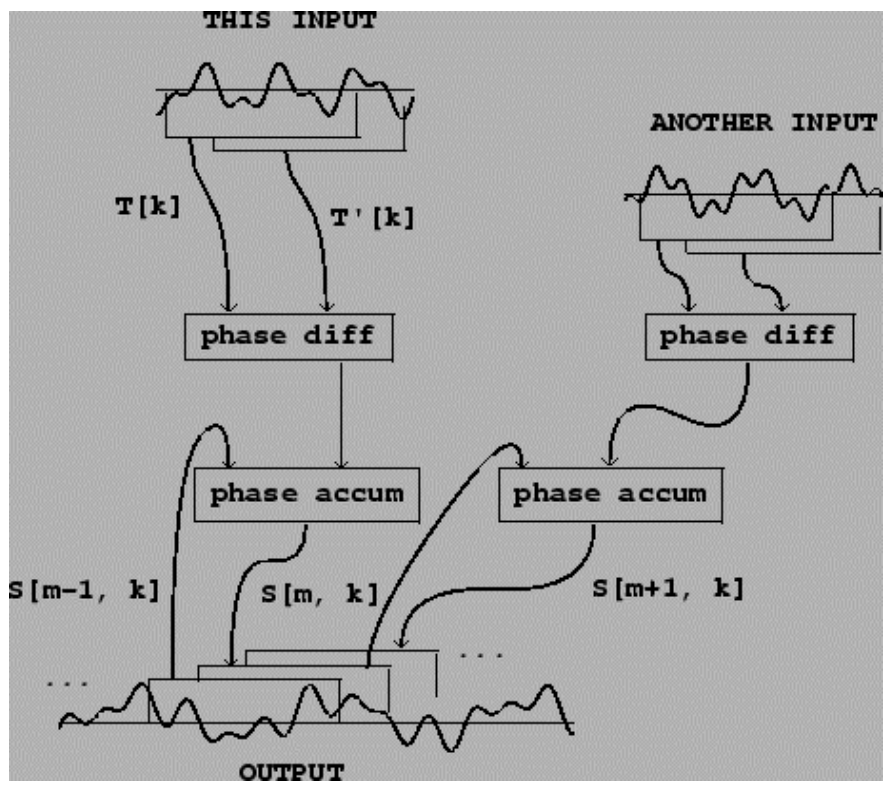

Figura 48 - Diagrama de Acúmulo de Fase (Puckette, 2006 p. 282).

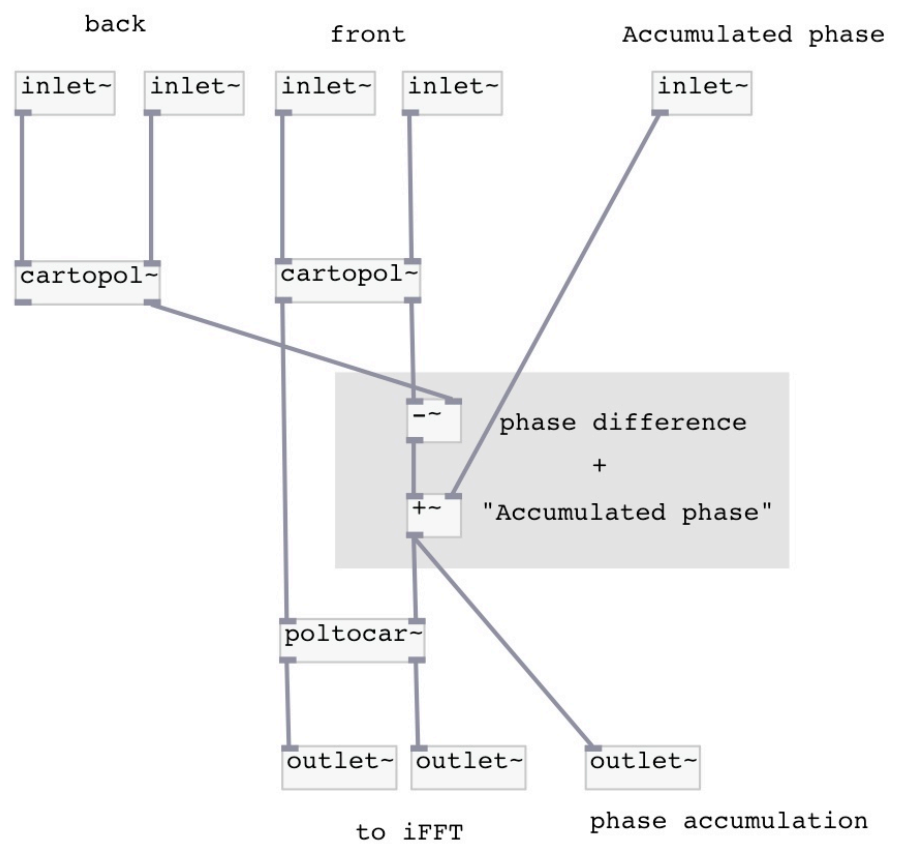

Figura 49 - Diagrama do Acúmulo de Fase em um Patch de Pd.

A figura 49 é um subpatch de Pd que computa esse acúmulo de fase. Da esquerda para a direita, as entradas são: a análise de FFT da janela traseira (dois primeiros inlets), a FFT da janela dianteira (dois inlets seguintes) e o último valor da saída de fase no inlet direito. O sinal de FFT chega na forma cartesiana e precisa ser convertido para a forma Polar, que dá os valores de amplitude e fase. A conversão é feita com objetos externos [cartopol ] (cartesiana para polar) e [poltocar ] (polar para 
cartesiana).

O outlet direito do objeto [cartopol ] é a fase. Dessa forma, podemos visualizar que o patch recebe a fase da janela dianteira e subtrai o valor da fase da traseira. Essa diferença é então somada com o último resultado de fase. O valor atual de fase é enviado para o outlet direito, mas essa saída é a mesma que retorna no inlet direito na próxima rodada. Após o cálculo de fase, os valores são convertidos de novo para a forma cartesiana e enviados para a FFT inversa.

Um método um pouco mais complicado de computar isso pode ser feito diretamente na forma cartesiana, envolvendo princípios de matemática complexa. Essa opção afere uma qualidade melhor de cálculo e também é mais rápida computacionalmente (mas não tão significativamente tão mais rápido nos dias de hoje). A implementação de Miller Puckette é baseada na forma cartesiana e inclui um elemento que gera mais coerência na distribuição da fase (Miller 1995). A técnica em si é um procedimento parecido com o exemplo "Sheep From Goats", porque usa o mesmo objeto [lrshift $]$.

Pela contração e expansão de tempo, a implementação deste Phase Vocoder depende de uma alocação de áudio em um buffer ("retentor" em inglês). Esse termo, em ciência da computação, diz respeito a um espaço de memória utilizado para escrita e leitura de dados. Um buffer de áudio é um espaço alocado para gravação para carregar sons pré-gravados. No Pure Data, um buffer consiste em apenas uma tabela, ou array. O buffer facilita o processo de analisar duas janelas consecutivas, além de que, para podermos tocar um som mais rápido que o original, ele precisa ter sido previamente gravado ou armazenado.

Uma mudança de tempo é dada por um contador que controla uma mudança de passos de leitura do buffer. Os passos podem ser mais rápidos ou lentos que o original. Sem a técnica de Phase Vocoder, isso implicaria em uma igual mudança de altura, da mesma maneira que tocar um disco de vinil mais rápido ou mais devagar muda igualmente a altura (metade da velocidade é metade da frequência, dobro da velocidade é o dobro da frequência). Porém, o Phase Vocoder é usado aqui justamente para prevenir isso.

O fator de transposição é dado por um novo tamanho de janela. Digamos que o tamanho da janela seja de 2048 amostras, e que a análise seja feita com 4 overlaps (um hop de 512). Nesse exemplo, um novo tamanho de janela de 1024 - a ser lida no mesmo espaço de tempo que a original (2048, seu dobro) - faz com que sua frequência 
caia pela metade. Uma nova janela de 4096 seria o dobro, ou uma oitava acima. Um novo tamanho de hop também é dado por essa nova janela, que define a diferença de leitura entre a janela dianteira e traseira.

Quando a velocidade de leitura está em um passo de acordo com novo tamanho de hop, ocorre o mesmo que no exemplo mencionado com o disco de vinil e não precisamos nos preocupar em aplicar um Phase Vocoder. Em termos práticos, a janela atual (ou dianteira) será exatamente a mesma janela lida como a última janela (ou traseira) na próxima rodada de análise. Portanto, as fases são as mesmas. A figura 50 ilustra esse processo com uma diferença de fase de 90 graus à esquerda.

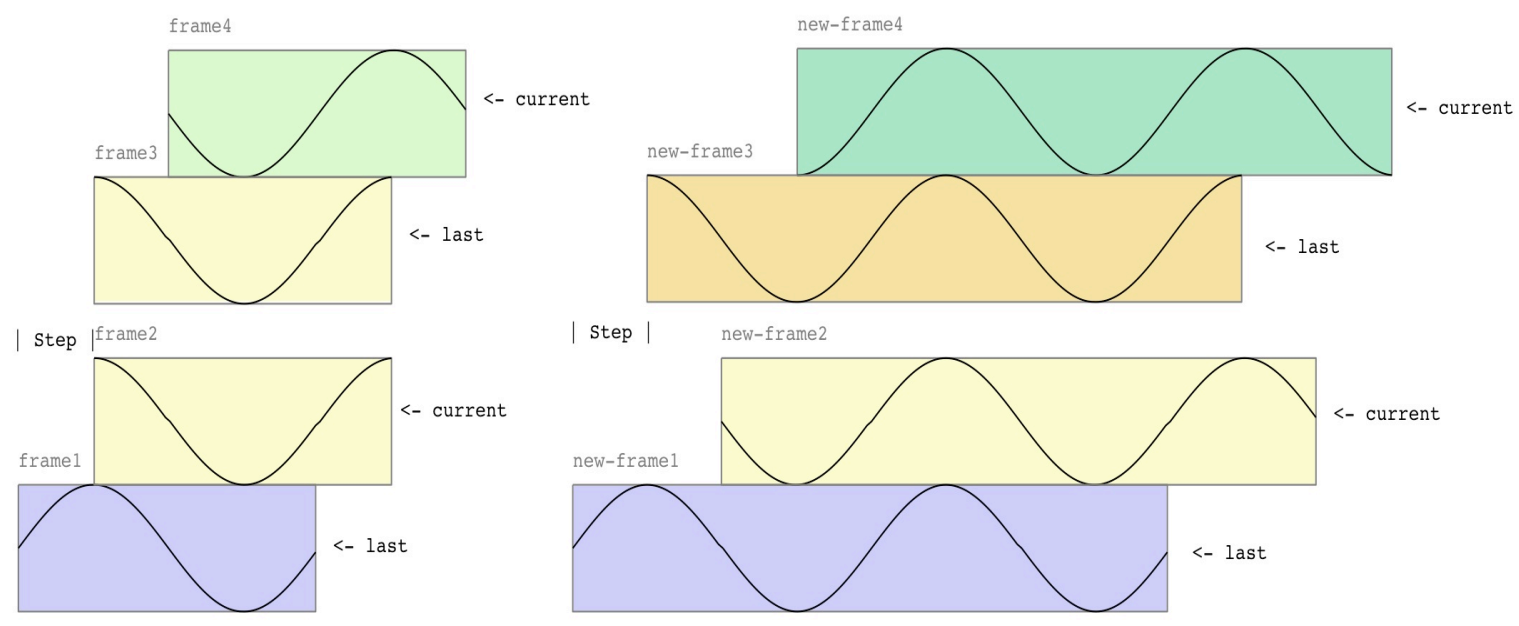

Figura 50 - Passo de leitura e tamanho de janela em concordância à esquerda e discordância à direita.

Na figura acima, à direita, temos um novo tamanho de janela que é o dobro e resulta, como já informado, em um dobro da frequência. Porém, o passo de leitura continua o mesmo (a metade disso). A ideia é que ele fosse o dobro (igual ao tamanho do novo hop). Digamos que nossa janela atual é a verde, na parte superior direita superior da figura 50, a diferença de fase com a janela atual da rodada anterior (em amarelo) é de 90 graus, e queríamos que fosse de 180 graus, para que a forma de onda fosse uma função seno (com início em zero graus).

Para isso, fazemos o acúmulo de fase. Pegamos a diferença de fase entre a janela atual e a janela anterior (de 180 graus) e somamos com a diferença anterior (também 180 graus). Isso nos dá então 360 graus (ou zero graus), o que equivale à mesma fase inicial da função seno, como se buscava. 
A figura 51 ilustra essa correção de fase inicial devido ao processo de acumulação, deixando evidente que o resultado equivale, na prática, a uma correção que faz que a janela seguinte esteja em um passo equivalente ao tamanho do hop, mesmo quando o passo de leitura é a metade disso ou qualquer outro valor diferente.

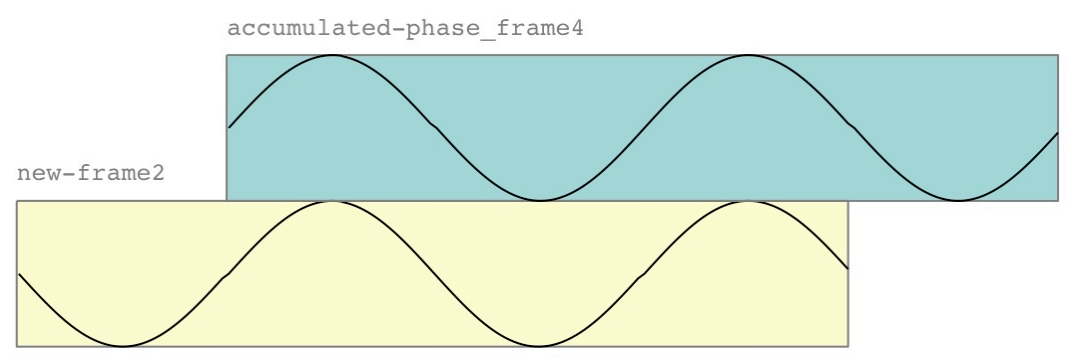

Figura 51 - Representação do resultado após acúmulo de fase.

\subsubsection{Harmonizador em Tempo Real}

Mais que apenas um Pitch Shifter, o patch "harmonizador" mantém o sinal original, o que faz que ele produza harmonias, ou melhor, díades com a cópia do sinal cuja altura foi alterada. Todavia, o patch permite que a capacidade de harmonizador seja desconsiderada, funcionando então apenas como um Pitch Shifter. A figura 52 traz duas versões de Harmonizadores em tempo real, uma baseado em Phase Vocoder e a outra em ressíntese. Uma adaptação necessária na versão do Phase Vocoder é a implementação de um buffer em anel (ou loop), para que a manipulação não seja interrompida ao chegar no final do buffer. Ambos os exemplos abaixo possuem um módulo que separa o ruído de fundo, que é mixado de volta na saída.
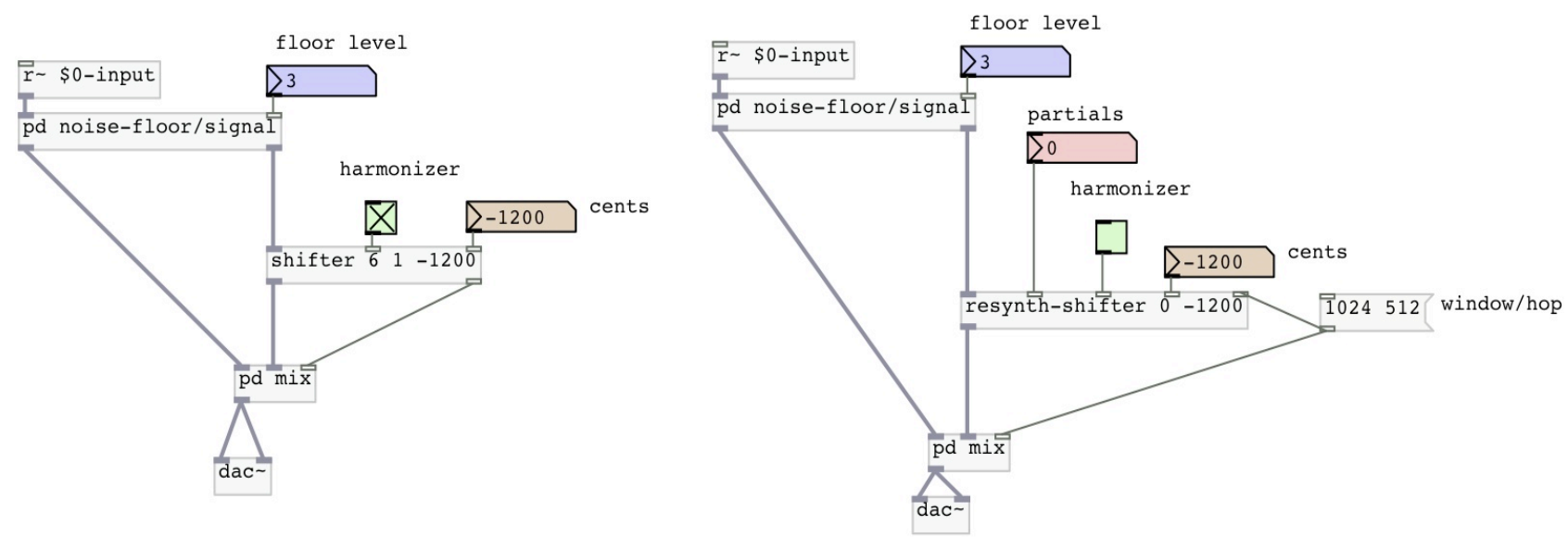

Figura 52 - Implementação de um harmonizer com Phase Vocoder (esquerda) e Ressíntese (direita), acoplados a um módulo que separa o ruído de fundo. 


\section{4 - Manipulação Espectral}

Os patches que veremos aqui têm como intuito alterar o conteúdo espectral de um sinal de áudio. Nosso maior interesse é alterar algumas qualidades sonoras pertinentes à nossa pesquisa. As aplicações práticas ficarão mais claras no decorrer do texto e na apresentação de outros patches que podem ser usados em conjunto.

O maior impacto nesta pesquisa é alterar um espectro harmônico e torná-lo, por exemplo, consideravelmente mais inarmônico. Esse processo influencia diretamente a percepção de Tonalness, produz um perfil de saliência distinto e também gera resultados diferentes em Curvas de Dissonância.

\subsubsection{Síntese Cruzada (Vocoder)}

A Síntese Cruzada é uma técnica que combina a informação espectral de dois sinais. Mais especificamente, gera um híbrido a partir de uma junção da informação de amplitudes de uma fonte e a fase de outra. Uma ampliação desse processo pode permitir que se multipliquem também as amplitudes de ambos os sinais, enquanto a informação de fase permanece intacta.

Há uma certa confusão terminológica a respeito dessa técnica. Ela se relaciona com o Vocoder, mas o processo também se assemelha à convolução espectral, em que multiplicamos dois sinais de FFT. Porém, a convolução em si gera um produto diferente, uma vez que também contabiliza uma soma das fases, enquanto o Vocoder mantém uma informação de fase original. Mas há quem deixe de lado esse tipo de cruzamento (ou soma) de fases na convolução e se refira assim a uma "convolução apenas das Amplitudes". Timbre Stamp (Estampa de Timbre) é como Miller Puckette chama essa técnica em seu livro (Puckette 2006), pois a considera mais pertinente que a relação com o Vocoder Clássico.

Por fim, há ainda um efeito de guitarra, chamado Talkbox, que, na prática, é um Vocoder, em que, normalmente, o som da voz é "cruzado" com o som processado de uma guitarra. O mesmo processo é comum em sintetizadores explicitamente denominados Vocoders, onde um microfone capta o som da voz e o combina com um programa de síntese. Tanto em um como em outro, a informação de fase que permanece é a dos timbres de instrumentos musicais. A informação de fase é a que carrega a informação precisa de resolução de frequência. Isso significa que é a sua qualidade tonal que prevalecerá. A questão, então, gira em torno do controle de envelope de amplitudes, ou melhor, de uma filtragem dessa informação de amplitudes, 
que nesses exemplos é feito com o som da voz/fala.

Há diversos plug-ins de Vocoder em softwares de edição e gravação musical. $\mathrm{Na}$ cultura popular atual, temos outro exemplo do uso dessa técnica que está sendo conhecida pelo jargão de "autotune" por meio desses plug-ins. Mais por, digamos, brincadeira, é possível combinar o áudio de uma entrevista de destaque na mídia e combinar com sons sintetizados. Desse modo, é possível forçar essa entrada de áudio a ter uma qualidade tonal e melódica.

A maior potencialidade da Síntese Cruzada em música é justamente inserir a qualidade tonal de uma entrada sonora em uma fonte sonora com pouca ou nenhuma qualidade tonal, o que the permite possuir uma alta complexidade textural, ou de transientes, como em sons ruidosos, de percussão e a voz. A motivação do uso dessa técnica em nossa pesquisa não foge a essa regra, em que buscamos forçar um espectro harmônico, ou mesmo inarmônico, em uma entrada sonora ruidosa, para depois combinarmos com outros elementos.

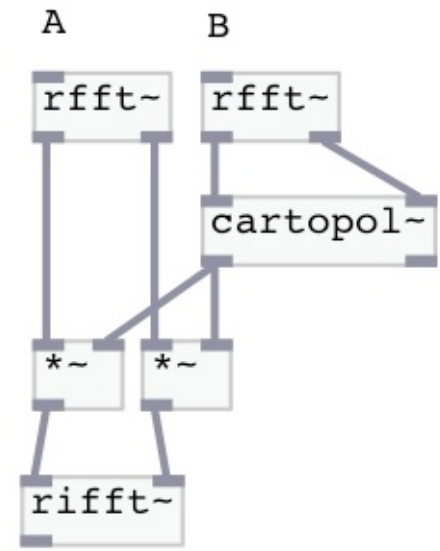

Figura 53 - Síntese Cruzada com a amplitude de ambas as fontes sendo multiplicadas.

$\mathrm{Na}$ figura 53, temos um patch simplificado que caracteriza o processo de Vocoder. As fases da fonte "A" são mantidas, e a amplitude é um produto das amplitudes de ambas as fontes. O método é, então, multiplicar a parte real e imaginária do sinal que se deseja manter a fase pelos valores de amplitude de uma segunda fonte. Para aniquilar as Amplitudes da fonte " $\mathrm{A}$ ", adotamos um processo de normalização das amplitudes, para que fiquem todas iguais a 1, mas ainda com a mesma informação de fase. Para isso, basta dividir o resultado pelo valor de amplitudes de A.

A figura 54 do livro de Miller Puckette (2006) mostra o diagrama de um 
Vocoder e inclui uma função limitadora (limiting function) que gradativamente corta (ou limita) uma divisão pelos valores de amplitude de A. Desse modo, na medida em que os valores passam, as amplitudes são normalizadas ao valor de 1 , o que faz que as amplitudes de A sejam continuamente extraídas do processo.

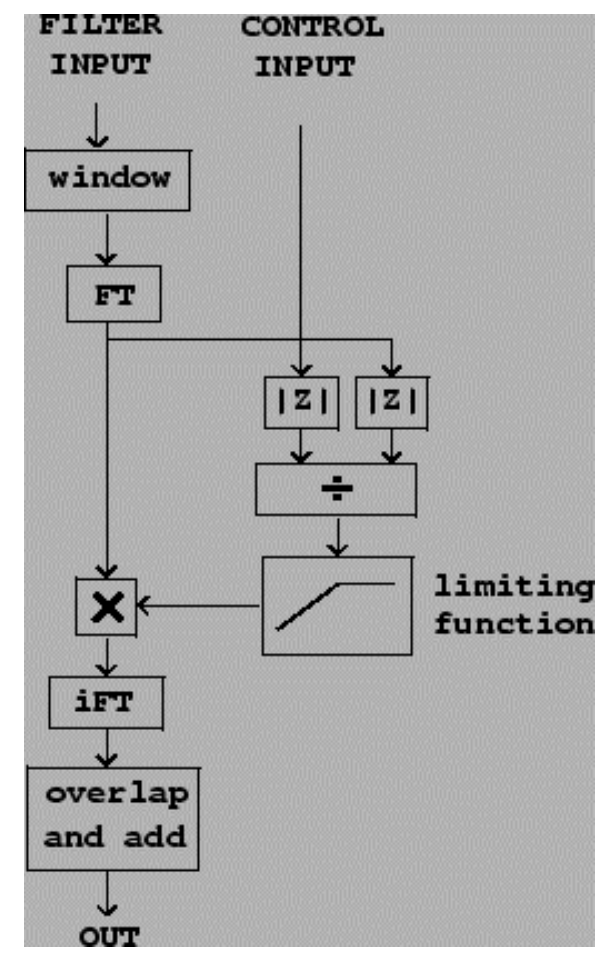

Figura 54 - Diagrama de Vocoder de Miller Puckette.

\subsubsection{Modulação de Amplitude}

Esta técnica consiste em controlar a amplitude de um sinal (agora estamos falando de um sinal no tempo, e não das amplitudes de uma FFT no domínio da frequência) com um oscilador, chamado de modulador, enquanto o sinal modulado se chama "portador". A modulação de Amplitude Clássica implica que o oscilador gere sinais Unipolares (positivos de 0 a 1). No caso de sinais Bipolares (entre -1 e 1), temos um caso especial de Modulação de Amplitude, a Modulação em Anel (Roads 1996).

A Modulação de Amplitude cria dois componentes espectrais para cada componente do som modulado. Esses novos componentes se dispõem em uma banda de frequência, acima e abaixo, que é igual à frequência do sinal modulador. No caso da Modulação em Anel, os componentes do sinal modulado simplesmente desaparecem, permanecendo apenas as bandas laterais. A frequência moduladora pode variar entre unipolar e bipolar, para controlar as amplitudes dos componentes originais. 
Podemos criar relações harmônicas e inarmônicas com técnicas de Modulação de Amplitude se soubermos a frequência do sinal portador. Para tal, precisamos detectar a frequência fundamental do som modulado. A partir dessa ideia, buscamos implementações com o [sigmund ] e também com o Perfil de Saliência de Alturas, para buscar frequências pertinentes a esse processo. E, assim, encontramos alguns exemplos interessantes, que consistem em modular um sinal harmônico por um frequência em que a fundamental do som modulado seja um múltiplo dela.

Por exemplo, no caso de uma modulação de Amplitude Clássica e de uma frequência moduladora igual à metade da frequência da Altura do som modulado, há uma transposição uma oitava abaixo. Além dessa transposição, criamos outros componentes espectrais. O exemplo abaixo mostra o que acontece com uma série harmônica com apenas 4 componentes a partir de $800 \mathrm{~Hz}$ :

$$
\begin{array}{ccccccc}
800 & - & 1600 & - & 2400 & - & 3200 \\
400 & -800 & -1200 & -1600 & & &
\end{array}
$$

Agora, podemos ir além e transpor de volta uma oitava acima. Desse modo, na prática, estendemos a série harmônica e criamos novos componentes espectrais. Há também o caso de uma Modulação em Anel, em que perdemos os componentes espectrais originais. Assim, em um primeiro passo, temos a sonoridade transposta uma oitava abaixo, e a perda de harmônicos pares.

$$
\begin{gathered}
800-1600-2400-3200 \\
400-\ldots-1200-\ldots-2000-\ldots-2800-\ldots-3600
\end{gathered}
$$

É também muito interessante apenas modular por frequências quaisquer sem preocupação de controle do resultado final, o que torna o sinal inarmônico de um modo imprevisto. O interesse está em, por meio das ferramentas implementadas, podermos analisar sons quaisquer e medir seu grau de harmonicidade, gerar escalas e encontrar intervalos interessantes, mesmo quando sabemos pouco sobre sua origem ou informação espectral. 


\subsubsection{Modulação Complexa (Spectral Shift e Compressão/Expansão Espectral)}

Esta técnica consiste em uma Modulação de Amplitude com sinais complexos. Uma abstração já presente nas distribuições de $\mathrm{Pd}$ nos fornece uma transformada de Hilbert, que permite tornar um sinal real em sinal complexo. Modulamos esse sinal então com uma senoide complexa. O resultado é parecido com a Modulação em Anel, pois os componentes espectrais originais se perdem no processo. Em compensação, temos apenas uma banda lateral de frequência em vez de duas. Por isso, interpreta-se que os componentes espectrais foram transpostos. Logo, uma modulação de $100 \mathrm{~Hz}$ arrasta todos os componentes espectrais $100 \mathrm{~Hz}$ acima. Uma transposição para baixo é possível se a frequência do oscilador for dado por um número negativo, que na verdade indica uma inversão de fase.

É importante frisar que isso não implica uma real transposição de Altura, pois os componentes espectrais precisariam ser deslocados de forma geométrica, mantendo a mesma relação proporcional entre os parciais, enquanto o deslocamento dos componentes com essa técnica é linear. No caso em que uma lista de componentes de 400, 800 e 1200 Hertz é deslocada uma oitava acima, todos os componentes dobram, resultando em: 800, 1600 e 2400 Hertz. Já um deslocamento por meio de Modulação Complexa nos dá: 800, 1200 e 1600 Hertz. Desse modo, como as relações se perdem, um som harmônico adquire qualidades inarmônicas.

Podemos também mudar a altura de um espectro que foi transposto linearmente para que sua fundamental permaneça a mesma. Entretanto, a qualidade espectral foi manipulada gerando inarmonicidades. Uma compressão (ou aproximação) dos componentes espectrais se dá quando arrastamos o espectro acima e depois transpomos novamente abaixo. A expansão (ou afastamento) dos componentes ocorre no processo inverso. A quantidade de compressão é dada pelo intervalo entre a Altura original da fundamental e a nova fundamental arrastada pela frequência de modulação.

No patch da figura 55, o parâmetro de controle de expansão é dado por um intervalo em cents, que também é o intervalo de mudança de altura. O som analisado é um Lá central tocado na flauta (que o [sigmund ] detectou como justamente em torno de $440 \mathrm{~Hz}$ ) com valor de 700 cents. Calculamos quanto temos que arrastar o espectro ao grave para compensar a mudança de altura, e o resultado é em torno de $146 \mathrm{~Hz}$ abaixo. Fazemos, então, a modulação complexa e inserimos o resultado em um Pitch Shifter. Por fim, analisamos o Tonalness do som original e o que foi expandido. A ideia é que a manipulação tenha tornado o som bem mais inarmônico, diminuindo a 
sensação e medida de Tonalness. O modelo implementado em pesquisa constatou essa queda de Tonalness, em que o resultado baixou de 0.43 para 0.25 .

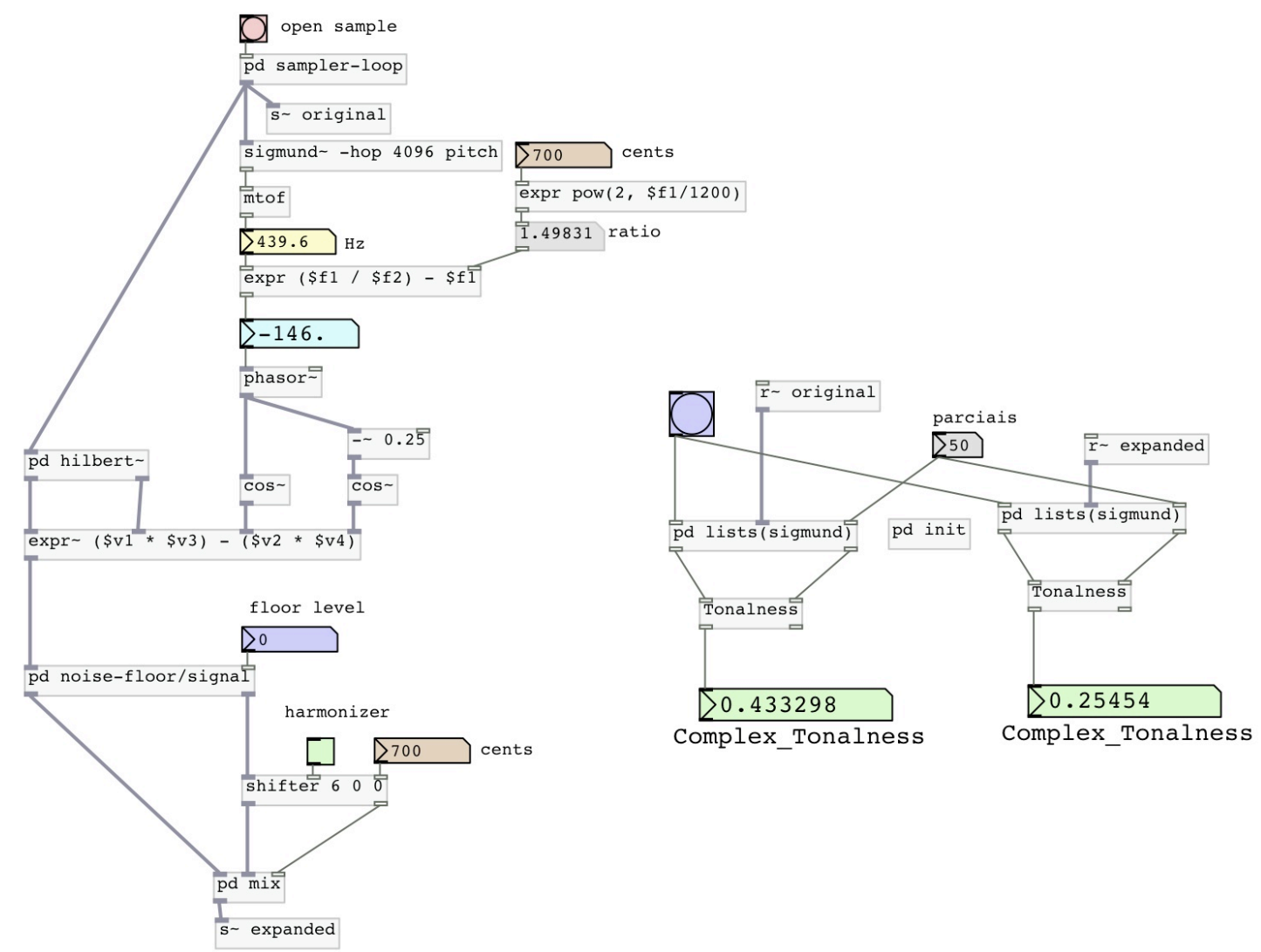

Figura 55 - Expansão espectral com modulação complexa e Pitch Shift.

No próximo exemplo da figura 56, analisaremos o efeito de uma manipulação espectral e o modelo de Fundamental do Acorde / Altura Virtual. Temos uma onda dente-de-serra com a fundamental em $240 \mathrm{~Hz}$ e sua série harmônica em que os componentes são múltiplos de $240 \mathrm{~Hz}$. Ao deslocarmos essa sonoridade $240 \mathrm{~Hz}$ acima por meio de uma modulação complexa, a fundamental muda para $480 \mathrm{~Hz}$, só que os componentes continuam espaçados em $240 \mathrm{~Hz}$. Diferentemente dos outros exemplos em que analisamos a fundamental, agora temos uma resolução em passos de 1 cent na geração do Perfil de Saliência. Podemos ver na figura 56 que a fundamental acusada é de $240.05 \mathrm{~Hz}$, que corresponde aproximadamente à fundamental ausente de $240 \mathrm{~Hz}$. Esse resultado aproximado é uma diferença de apenas 0.36 cents, dada essa maior resolução do Perfil de Saliência. A lista de frequências dada pelo [sigmund ] é dada em uma caixa de mensagem. 


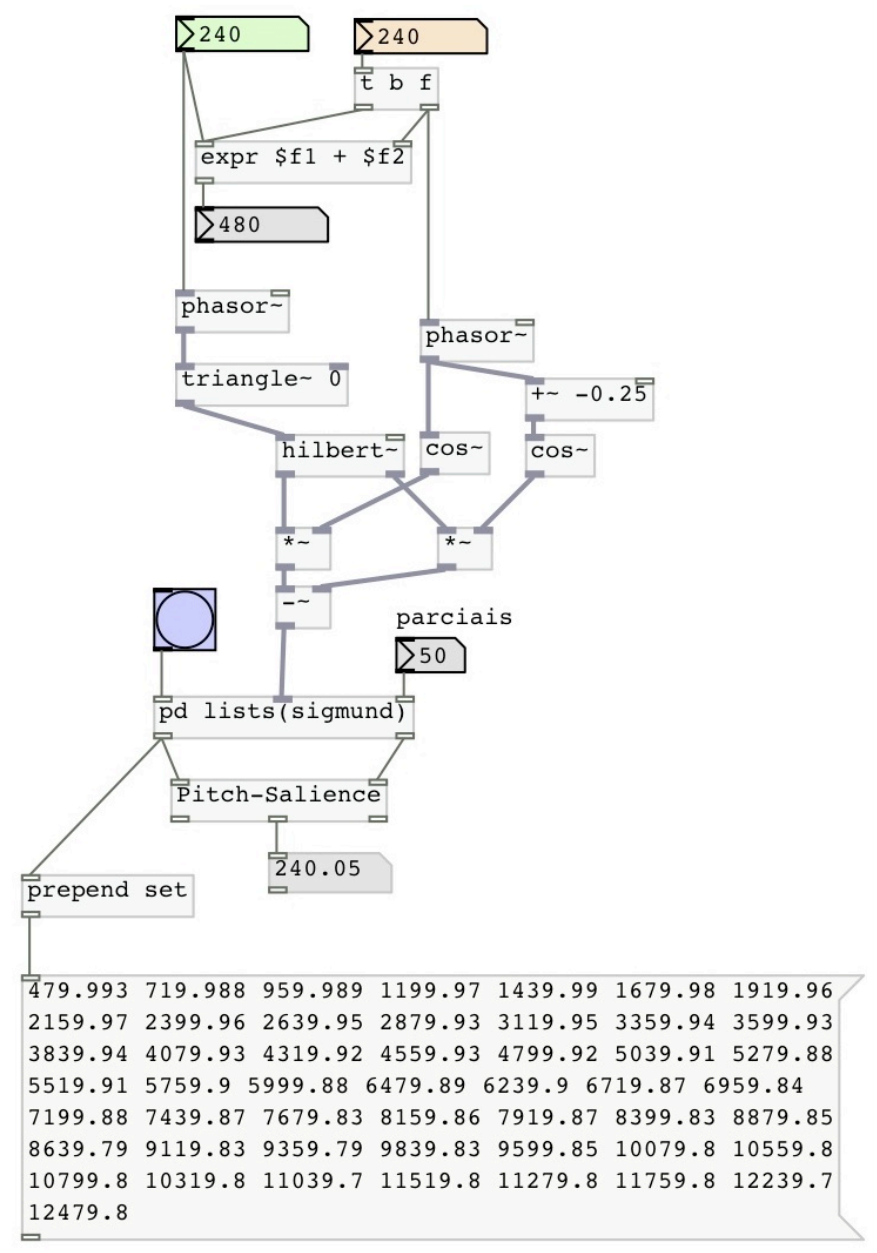

Figura 56 - Fundamental (no caso ausente) de uma sonoridade inarmônica.

\subsubsection{Controle Arbitrário de Parciais via Ressíntese}

Com um banco de osciladores, podemos buscar aplicações mais aprimoradas e avançadas de controles arbitrários dos parciais, como uma mudança de altura independente para cada parcial, já que cada um corresponde a um oscilador. Para isso, jogamos todas as frequências dos parciais encontrados em uma tabela.

Como o [sigmund ] nos dá os parciais na ordem do mais proeminente ao mais fraco, a lista de frequências precisa ser devidamente ordenada do mais grave ao agudo. Os patches que separam ruído de fundo são particularmente úteis aqui, pois nos poupam processamento ao permitir que menos osciladores sejam empregados na ressíntese. Mas podemos ainda filtrar dentre os picos acusados e ficar só com os mais presentes de acordo com um patamar, ou mesmo definindo um número máximo de parciais.

Após essa filtragem, podemos ordenar as frequências em uma tabela. Já com uma outra tabela, podemos aplicar um valor de variação de altura para cada ponto, de 
modo que cada índice da tabela represente a ordem da série de parciais. O que precisamos agora conferir, em cada oscilador, é se a frequência que chega está na tabela ordenada e filtrada. Se estiver, verificamos seu índice para buscar o valor de transposição na tabela de variação de altura.

Como se trata de uma tabela, podemos armazenar seus dados ou carregar outros. Um controle de cada parcial é dado também por sliders, o que é uma interface mais amigável e fácil de operar do que inserir dados diretamente na tabela. Controladores externos, também com sliders ou outros botões, podem ser usados para facilitar essa interface de controle.

Algumas rotinas especiais podem ser desenvolvidas para gerar padrões de desafinação nessa tabela, como um fator de compressão e expansão do espectro, análogo ao que apresentamos anteriormente com modulação complexa. A figura abaixo representa esse sistema, em que os parciais de uma onda dente-de-serra são desafinados por uma tabela.

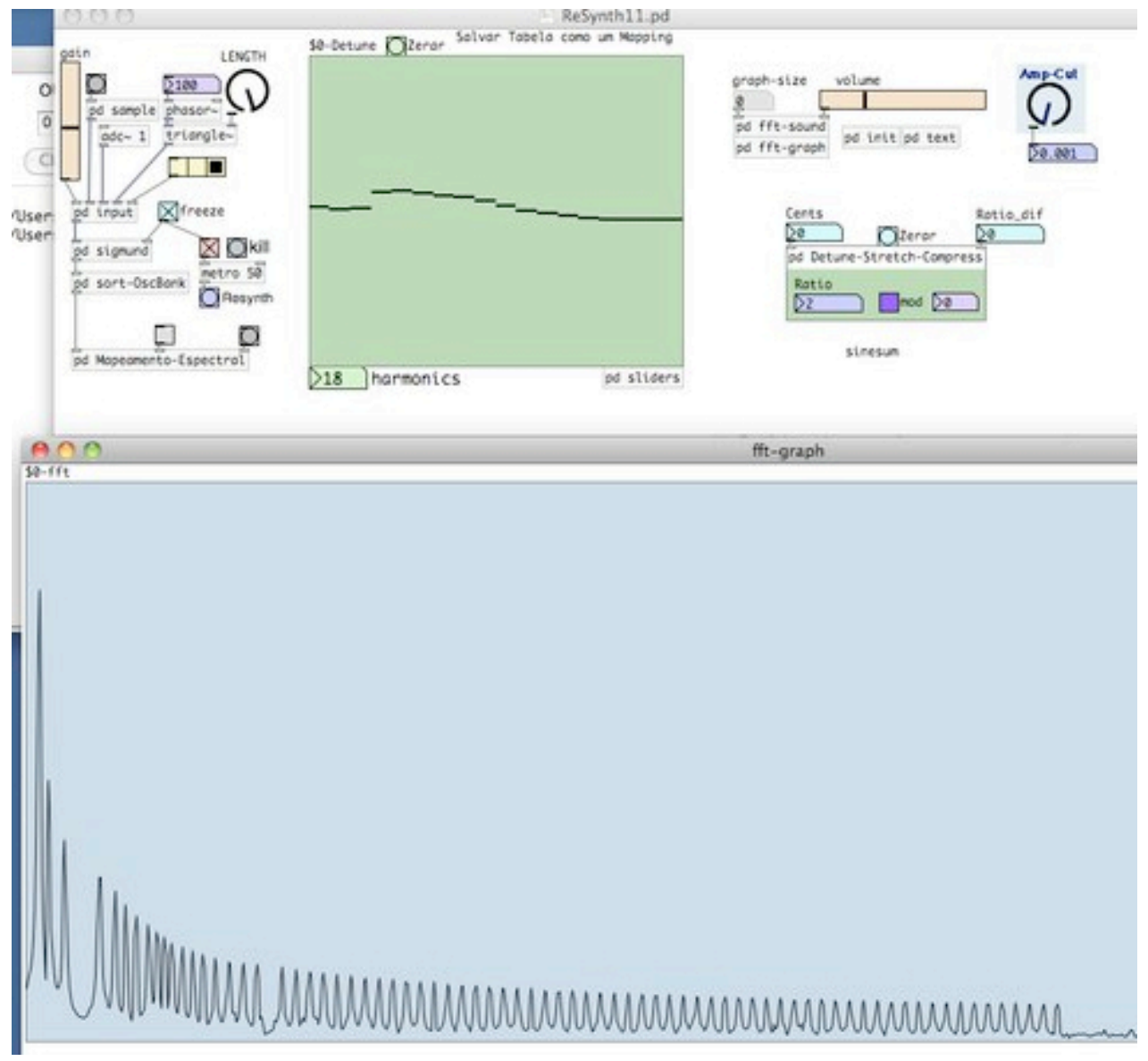

Figura 57 - controle arbitrário e independente de parciais. 


\subsubsection{Mapeamento Espectral}

Uma aplicação especial da capacidade de controle dos parciais é possível levando em consideração a relação entre escala e espectro sonoro. A partir desse conceito, conseguimos gerar escalas a partir de espectros, mas podemos também fazer o caminho inverso, que é partir de uma escala e gerar um espectro que seja compatível com ela. Mais interessante, porém, é partir de um espectro qualquer, analisado em tempo real, e transformá-lo para que se aproxime de um modelo baseado em uma escala. Essa técnica foi chamada de Mapeamento Espectral Baseado em Consonância por Sethares (1999), que foi o primeiro a explorar e desenvolver ferramentas para esse fim.

Em nossa implementação, temos um patch de Pure Data que calcula uma nova série harmônica de acordo com uma escala qualquer dada em cents, inclusive as que não são baseadas na oitava. Como um primeiro exemplo, vejamos o resultado de geração de uma nova série a partir da escala do temperamento igual, que divide a oitava em 12 intervalos iguais.

Em cents, a entrada de valores é: 1002003004005006007008009001000 1100 1200. A nova série é gerada ao encontrar qual intervalo desses está mais perto de um termo da série harmônica. O terceiro harmônico, por exemplo, está próximo de 700 cents, o quinto se aproxima de 400 cents e assim por diante. Eis que esses termos são substituídos por números que correspondem a esses intervalos. O tamanho da série é um parâmetro dado na geração. No exemplo abaixo, temos 64 termos. A oitava é o único intervalo que coincide com termos da série harmônica e corresponde às potências de dois, marcadas abaixo em negrito:

Nova Série: $\underline{\mathbf{1}} \underline{\mathbf{2}} 2.99661 \underline{4} 5.039685 .993237 .12719 \underline{\mathbf{8}} 8.9797 \quad 10.0794$

$\begin{array}{lllllllllll}11.3137 & 11.9865 & 12.6992 & 14.2544 & 15.102 & \mathbf{1 6} & 16.9514 & 17.9594 & 19.0273 & 20.1587\end{array}$

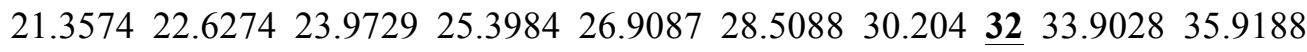

$38.054640 .317542 .714945 .254847 .945850 .796853 .817457 .017560 .408 \underline{\mathbf{6 4}}$

O próximo passo agora é analisar os dados obtidos na ressíntese e, a partir da série de frequências ordenadas, encontrar a série harmônica real, que não necessariamente será uma série harmônica perfeita, formada por uma sequência de números inteiros. Dessa série obtida, comparamos com a nova série gerada a partir da escala e encontramos os intervalos de diferença, que são inseridos na tabela usada para reafinar os osciladores. 
Agora um segundo exemplo de uma escala que divide uma décima segunda em 13 intervalos iguais, também conhecida como a escala de Bohlen-Pierce (Pierce 2001 p. 183). Os únicos intervalos que correspondem à série harmônica são o número 3 e seus múltiplos, marcados em negrito. A série vai até o $64^{\circ}$ harmônico, que no caso foi substituído por 62.9161, próximo da oitava.

Escala: $146.301 \quad 292.608 \quad 438.912 \quad 585.218 \quad 731.524 \quad 877.827 \quad 1024.13$

1170.431316 .741463 .041609 .341755 .651901 .95

Série da Escala: $11.96613 \underline{3} 3.932265 .06695$ 6 7.227227 .864529 .3127

$\begin{array}{llllllllll}10.1339 & 11.0276 & \underline{\mathbf{1 2}} & 13.2831 & 14.4544 & 15.729 & 17.1161 & 18.6254 & 18.9462 & 20.2678\end{array}$

$\begin{array}{llllllllll}20.617 & 22.0551 & 22.435 & \mathbf{2 4} & 24.4134 & 26.5662 & 28.9089 & 31.4581 & 34.2322 & 37.2508\end{array}$

$37.892540 .535641 .233944 .110244 .8701 \underline{\mathbf{4 8}} 48.826953 .132557 .817862 .9161$

Um último parâmetro nos permite não forçar todos os parciais a serem relocados aos termos da nova série. Podemos estipular uma diferença máxima em que o parcial deve estar dentro para que então seja reafinado. Esse procedimento foi implementado porque às vezes vale a pena alterar apenas alguns parciais da série, como quando temos apenas poucos intervalos para gerar uma nova série, que mal caracterizam um Sistema de Afinação. Por exemplo, a entrada pode ser uma divisão da oitava em apenas 4 intervalos, que nos dá um acorde diminuto e os intervalos de 300, 600, 900 e 1200 cents. Com isso geramos a seguinte série:

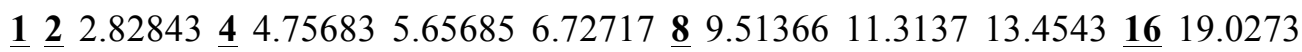
$22.627426 .9087 \underline{\mathbf{3 2}} 38.054645 .254853 .8174 \underline{\mathbf{6 4}}$

Essa lista contem apenas 20 itens e está bem incompleta em relação às listas anteriores geradas por outras escalas. Apenas os parciais que estejam, digamos, numa proximidade de 0.5 (acima ou abaixo) desta lista serão remapeados. Os outros parciais que não estão nesse raio de proximidade permanecem intactos.

Outra forma de não reafinar todos os parciais encontrados na análise é a partir do filtro mencionado anteriormente, em que podemos estipular um número máximo de parciais a serem manipulados, o que nos dá apenas os harmônicos com maior energia.

Todos esses controles permitem que a manipulação seja minuciosamente controlada, de modo que o usuário pode experimentar até encontrar uma alteração espectral que lhe satisfaça. Os parâmetros podem ser processados em tempo real e isso também abre uma margem para transformação contínua do som de uma forma muito 
dinâmica.

Tendo essa opção em mente, foi inserido ainda outro controle que permite fazer uma "metamorfose" entre o som original e o destino do mapeamento espectral. O controle "morph" é um valor de 0 a 1 , que é multiplicado pelos valores da tabela de reafinação. Logo, se é igual a 0 , nenhuma reafinação acontece e, se for igual a 1 , a transformação é completa.

Por fim, um último cuidado na transformação é um detector de ataques (com o objeto nativo [bonk ]), que corta, da mesma maneira que o controle de "morph" o processamento no momento em que detecta um ataque. Isso faz que a qualidade sonora de um ataque seja preservada, mantendo-se fiel, assim, à percepção do timbre original, visto que o momento de ataque é um dos elementos fundamentais no reconhecimento de timbre (Schaeffer 1966). Outro fator é que, no momento do ataque, o resultado de um processamento desse tipo gera resultados sonoros desastrosos, uma vez que a informação espectral chega a ser caótica, dificultando bastante a capacidade de apenas operar sobre os parciais relevantes.

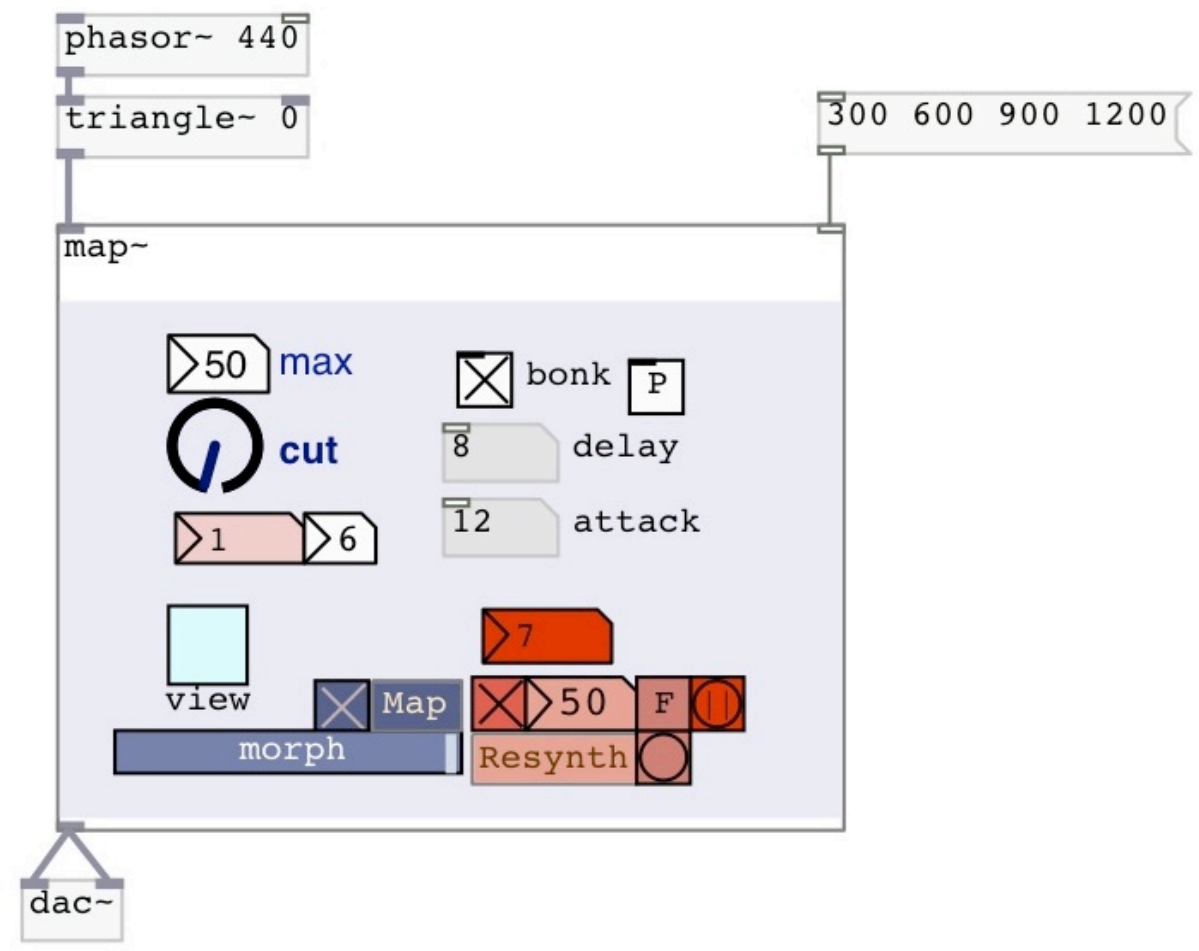

Figura 58 - Módulo de mapeamento espectral, de acordo com um acorde diminuto (intervalos de 3006009001200 cents). 


\section{5 - Curvas de Dissonância e Geração de Escalas a partir de Sonoridades}

As Curvas de Dissonância são gráficos que representam valores de dissonância para intervalos musicais, ou melhor, díades. Os atributos que descrevem a dissonância são o foco de discussão nesta tese, em que a Aspereza possui um forte destaque, uma vez que, desde seu aparecimento na literatura, seu modelo já foi usado para gerar gráficos dessa ordem. A Figura 9, apresentada na seção 5.2 sobre Modelagem de Aspereza, é um exemplo do modelo de Helmholtz (1877). Nesse gráfico, a Aspereza está relacionada com a Dissonância Sensorial. Na sequência, a figura 10 é outra Curva, porém invertida (de consonância em vez de dissonância, com os valores de Aspereza de cima para baixo).

Antes disso, porém, na subseção 4.3.1 (Fusão Tonal), a Figura 6 - dos resultados de Stumpf (1890) - também pode ser encarada como uma Curva de Consonância. Na seção 5.5, a Figura 13 traz o modelo de Barlow recriando a Figura 10 e comparando com os resultados da curva de Harmonicidade, que apontamos ter semelhança com a figura 6. E na figura 14, temos mais uma Curva de Dissonância dada pela medida de Entropia Harmônica.

O ponto de discussão é que não somente a Aspereza deveria ser adotada como única dimensão da Curva de Dissonância. Essa discussão será tratada na próxima parte, onde retomaremos a discussão teórica e apontaremos para as conclusões finais. Nesta seção apenas apresentamos a estrutura e funcionamento do patch que gera curvas.

Nosso interesse é, claramente, gerar curvas com os atributos estudados. Além da Aspereza, que mede o alinhamento dos parciais, podemos, como uma segunda dimensão da Dissonância Sensorial, gerar curvas com o modelo de Tonalness, que contabiliza as relações harmônicas de intervalos musicais. O Brilho, porém, não gera resultados significativos ou úteis em uma curva de intervalos musicais, pois não mede o alinhamento de parciais, tampouco relações harmônicas ou inarmônicas.

No tocante aos atributos da Harmonia, o descritor de Fundamental do Acorde também não gera curvas, pois só indica o Baixo Fundamental da díade. Todavia, podemos entendê-lo como um desdobramento do modelo de Tonalness, já que a Fundamental do Acorde depende diretamente da medida desse atributo, e será mais proeminente de acordo com a medida de um alto Tonalness. Por fim, temos a Comonalidade de Altura, que pode ser usada como uma medida paralela. Em compensação, não podemos usar o mesmo patch gerador de curvas com o objeto 
[Pitch-Commonality], já que esse objeto possui uma estrutura diferente de comparação e necessita de uma adaptação simples para esse objetivo.

Não obstante, o objeto é capaz de ser usado para gerar curvas, tanto que, no exemplo da figura 44, usamos o objeto para comparar intervalos musicais e os resultados podem ser utilizados para gerar um gráfico em forma de curva. A figura 59 representa justamente isso: temos os mesmos dados obtidos anteriormente dispostos em um gráfico de curva, que poderiam ter vindo diretamente da saída do objeto. Lembremos que o dado sonoro analisado são díades de ondas dente-de-serra, em uma oitava de $440 \mathrm{~Hz}$ a $880 \mathrm{~Hz}$.

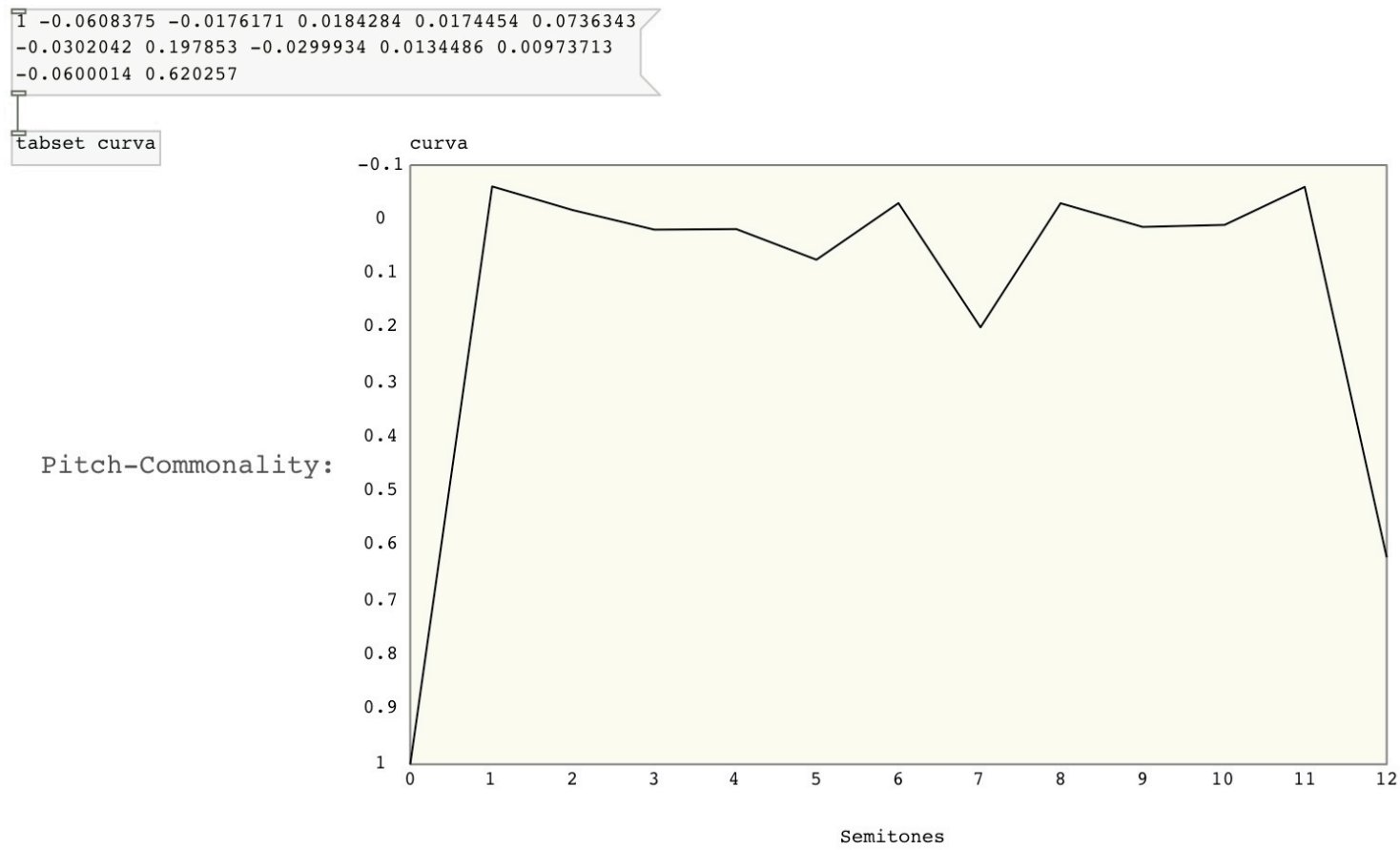

Figura 59 - Curva de Comonalidade de altura para 13 intervalos musicais do sistema temperado (do uníssono à oitava).

Assim, para que o objeto funcione como um gerador de curva, precisamos armazenar uma série de Perfis de Saliência de Altura na ordem desejada. É comum que a estrutura das curvas seja de forma ascendente como esta, do uníssono até a oitava, medindo díades formadas por um mesmo espectro sonoro. No exemplo anterior, temos passos de semitom, mas é desejável uma resolução maior, que nos dá uma curva propriamente dita, em passos de 1 cent, por exemplo.

Sobre algumas primeiras conclusões, podemos notar que não há muito contraste entre os valores dados pela Comonalidade de Altura, que a maior variação se 
dá para os intervalos de oitava, quarta e quinta justa e como não há muita diferença entre o trítono e a segunda menor. Note-se, na figura 60, como a Aspereza, por exemplo, nos dá um contraste maior. Na linha superior dessa figura, temos os mesmos resultados da figura 44, dados pelo modelo de Comonalidade de Altura. Já a linha de baixo é dada pelo modelo de Aspereza para o mesmo som analisado anteriormente e no mesmo registro, sem redimensionamento das amplitudes ou mascaramento e com o método de extrair a média quadrática de Barlow (2008) como Peso de Amplitude. O modelo de Aspereza acusa uma maior dissonância (ou desalinhamento de parciais em torno de um quarto da Banda Crítica) para os intervalos de segunda menor e sétima maior, por exemplo.

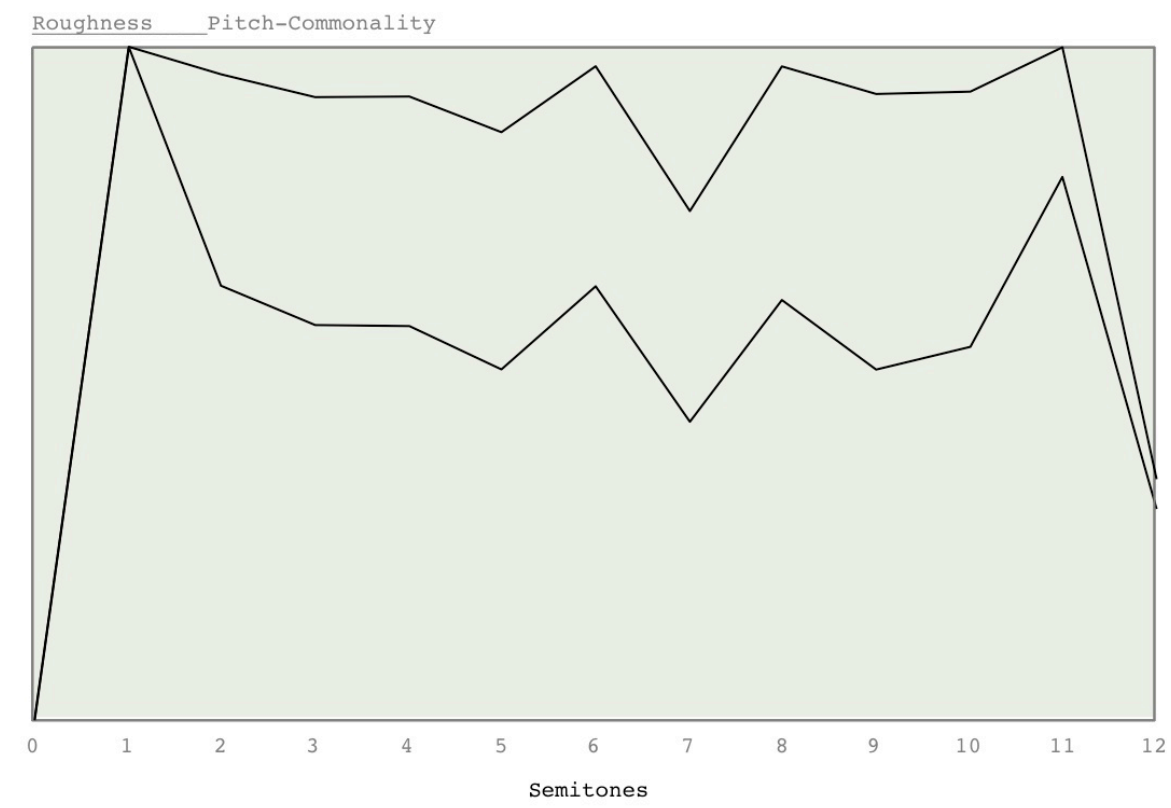

Figura 60 - Comparação entre Comonalidade de Altura e Aspereza.

Vejamos agora a estrutura básica do patch gerador de Curvas na figura 61, que consiste em receber uma lista de componentes espectrais (Frequências e Amplitudes) e duplicar essa lista para formar díades. Enquanto a lista original se mantém intacta, a cópia é transposta em passos dados até um intervalo máximo especificado. Esse intervalo, o ponto inicial, o tamanho de passos e o intervalo máximo (ou registro) são dados como argumentos em cents. Assim, para gerar um gráfico como o da figura 60, damos o argumento do registro (uma oitava: 1200 cents), o ponto inicial da curva (uníssono: 0 cents) e o tamanho do passo de transposição (um semitom: 100 cents). 


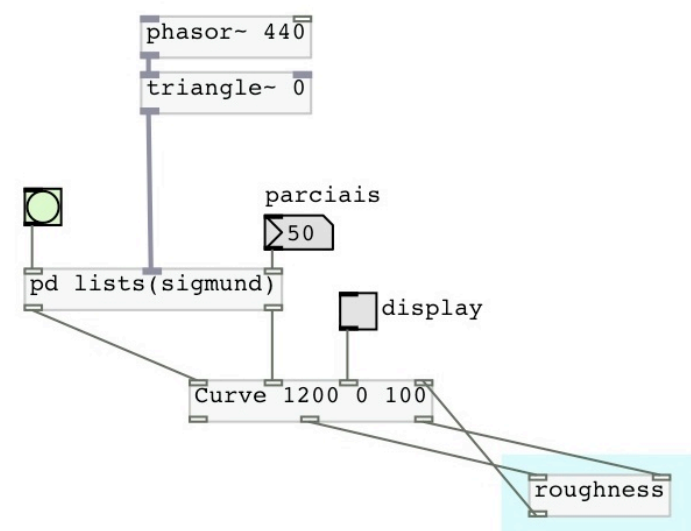

Figura 61 - Patch gerador de Curvas de Dissonâncias, com a abstração [Curve].

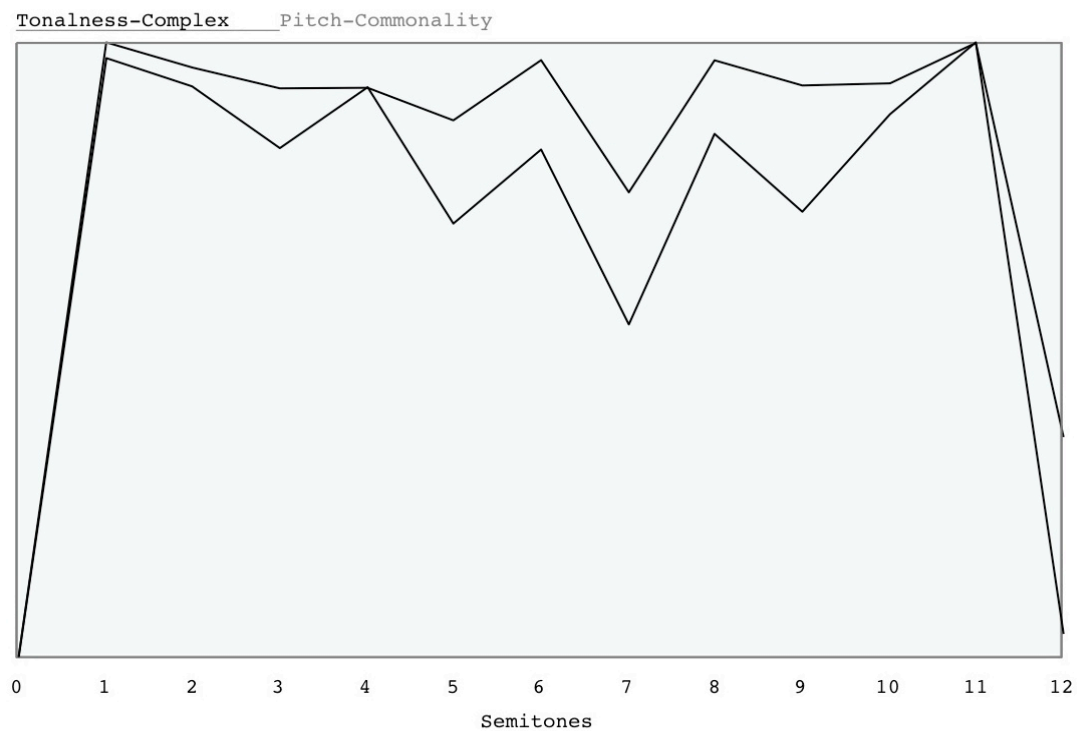

Tonalness-Pure Roughness

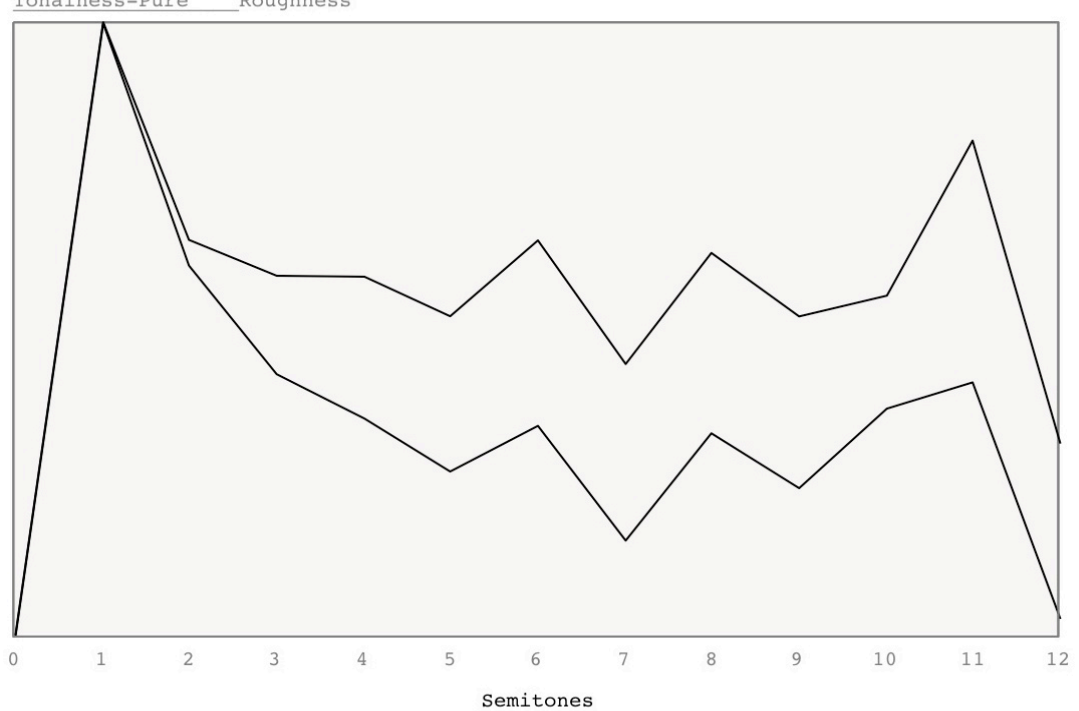

Figura 62 - Comparação entre atributos (Tonalness Complexo e Comonalidade de Altura Acima, e Tonalness Puro e Aspereza Abaixo). 


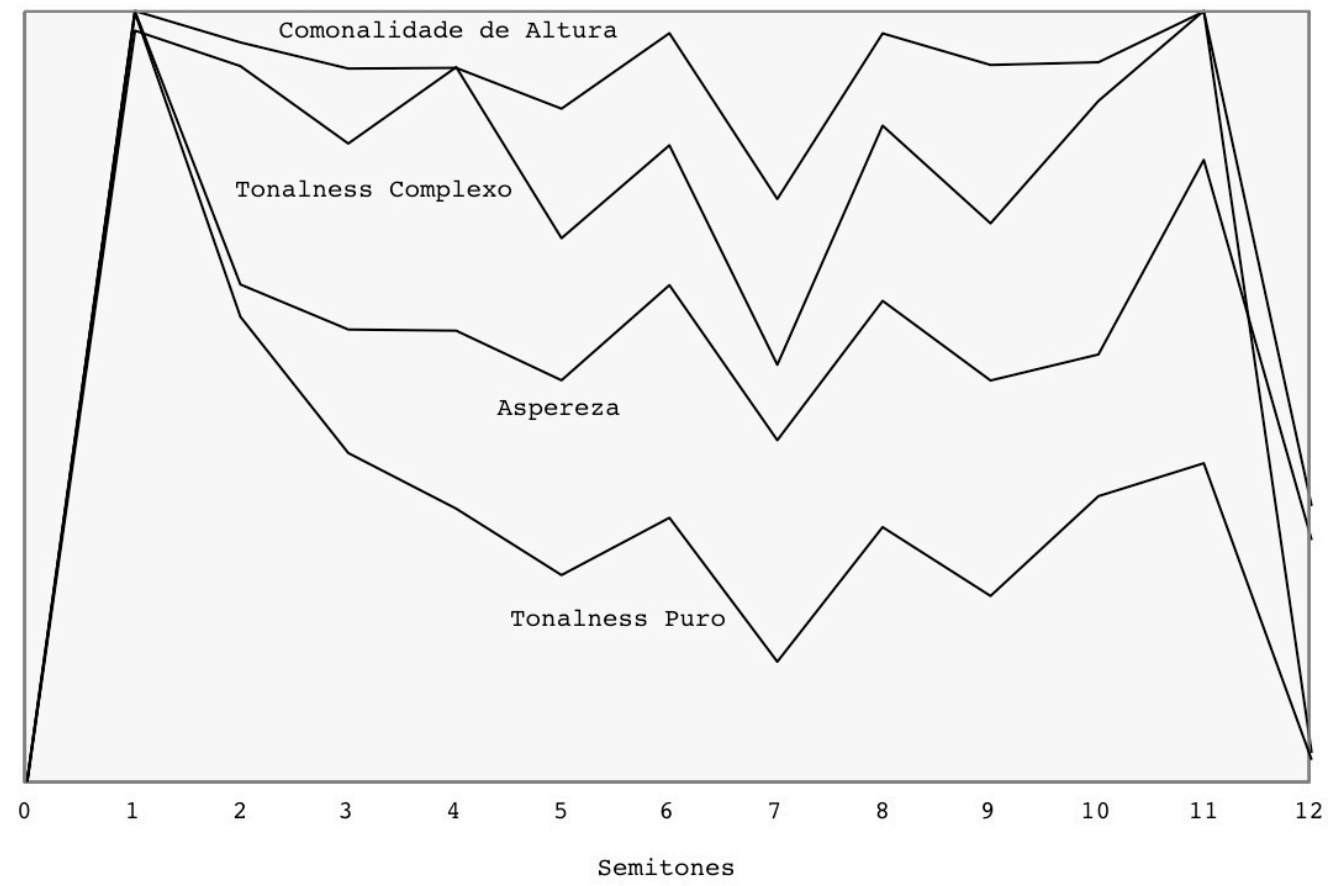

Figura 63 - Comparação dos quatro atributos.

Na figura 61, o patch analisa uma onda dente-de-serra a $440 \mathrm{~Hz}$. Extraímos listas de 50 componentes espectrais com o subpatch [pd lists(sigmund)] e as enviamos para a abstração [Curve], com os argumentos previamente mencionados. As listas geradas formam díades e são enviadas para um objeto de um dos atributos. No caso, a análise foi feita com o objeto [roughness], de Aspereza. O resultado para cada díade retorna para o objeto de curva, que guarda os valores em uma tabela. $\mathrm{Na}$ figura 62 , temos também as medidas de Tonalness Puro e Complexo e, na figura 63, temos os quatro atributos comparados entre si.

Lembrando o conceito de Tonalness Puro, sua medida decai junto com a queda de energia dos parciais, dada pelo mascaramento. Como o mascaramento se dá entre parciais em uma mesma banda crítica, essa medida possui um contraste similar dado pelo modelo de Aspereza. Já o Tonalness Complexo depende diretamente do modelo de Altura Virtual e indica uma maior ou menor relação harmônica. Ele está, portanto, mais próximo da medida de Comonalidade de Altura. Outras análises e discussões teóricas sobre as Curvas de Dissonância serão desenvolvidas na parte final desta tese.

Vejamos agora a Curva de Aspereza da Figura 64, com passos de 1 cent, e como podemos gerar escalas com pontos máximos e mínimos da Curva. A mesma entrada sonora agora é analisada com uma maior resolução, e as Curvas se assemelham aos desenhos das Figuras 9, 10 e 13. Podemos, assim, encontrar quais são os pontos 
máximos e mínimos dessa curva, dados que são fornecidos pelo outlet esquerdo do objeto [curve].

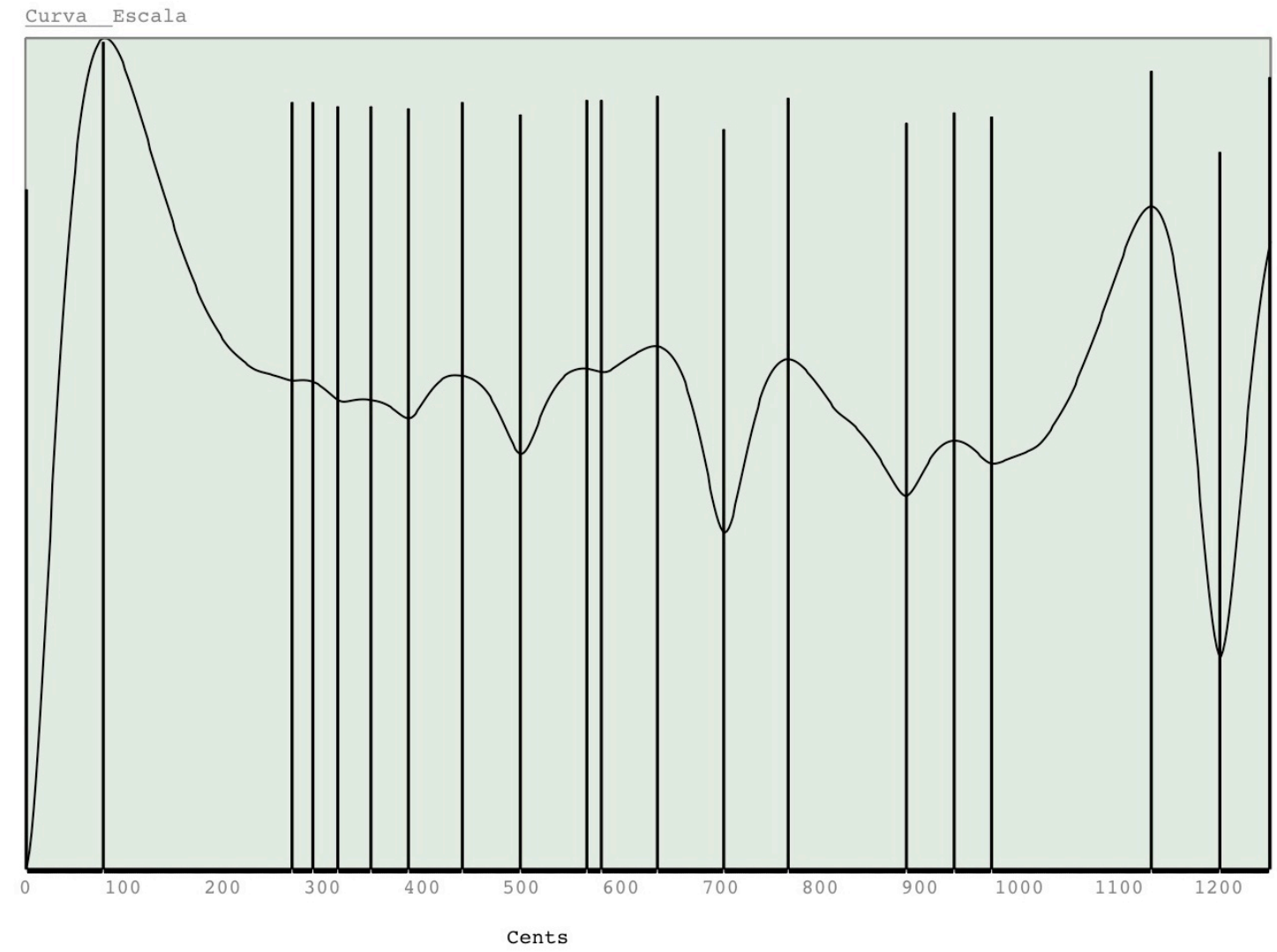

Figura 64 - Curva de Aspereza com uma resolução de passos de 1 cent.

Os pontos sempre se alternam entre um ponto mínimo (pares) e máximo (ímpares), ou seja, alternam entre consonâncias e dissonâncias. Esses pontos estão marcados em linhas na figura 64, e podemos ver que em alguns casos há pouquíssimo contraste entre uma consonância e dissonância adjacente (mesmo assim, há mais do que os resultados dados por uma Comonalidade de Altura).

A seguir, analisamos os pontos mínimos e máximos dados pela análise de Aspereza. Todos os pontos mínimos, nesse caso, correspondem bem a intervalos justos. Como o som analisado é uma onda dente-de-serra - ou seja, um tom complexo harmônico com energia em todos os parciais -, era de se esperar que os resultados dos pontos mínimos fossem próximos a intervalos justos. $\mathrm{O}$ interessante, todavia, é partir de sonoridades cujos resultados são difíceis de prever e, assim, adotar a análise como uma forma de nos dar respostas. Veremos alguns exemplos como estes no próximo capítulo, no sistema que engloba todas as técnicas aqui expostas. Segue abaixo a 
Figura do Patch que nos dá os pontos da escala, e, em seguida, esses pontos em uma tabela de comparação com intervalos justos.

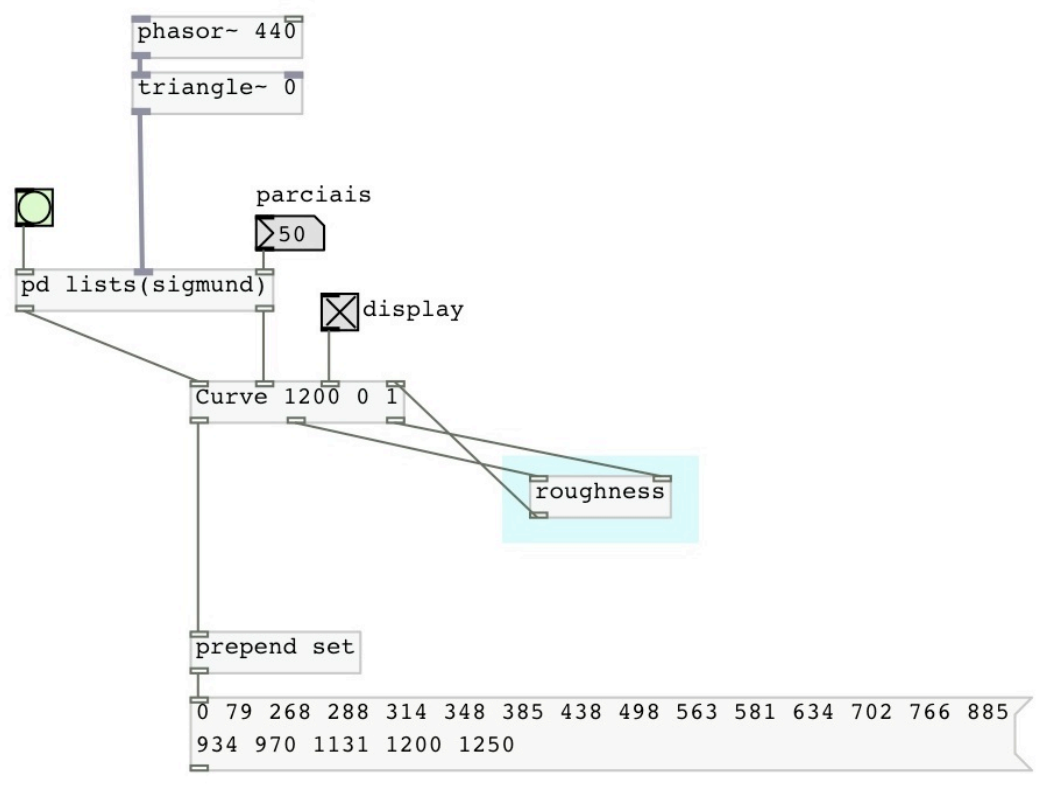

Figura 65 - Escala com pontos máximos e mínimos da Curva.

Tabela 10. Escala do Espectro

\begin{tabular}{|c|c|c|}
\hline Passo & cents & intervalo próximo \\
\hline 0 & 0 & {$[1: 1]$} \\
\hline 1 & 79 & \\
\hline 2 & 268 & {$[7: 6]-266.87$ cents } \\
\hline 3 & 288 & \\
\hline 4 & 314 & {$[6: 5]-315.64$ cents } \\
\hline 5 & 348 & \\
\hline 6 & 385 & {$[5: 4]-386.31$ cents } \\
\hline 7 & 438 & \\
\hline 8 & 498 & {$[4: 3]-498.04$ cents } \\
\hline 9 & 563 & \\
\hline 10 & 581 & {$[7: 5]-582.41$ cents } \\
\hline 11 & 634 & \\
\hline 12 & 702 & {$[3: 2]-701.95$ cents } \\
\hline 13 & 766 & \\
\hline 14 & 885 & {$[5: 3]-884.35$ cents } \\
\hline 15 & 934 & \\
\hline 16 & 970 & {$[7: 4]-968.82$ cents } \\
\hline 17 & 1131 & \\
\hline 18 & 1200 & {$[2: 1]$} \\
\hline
\end{tabular}

Por fim, apresentamos adaptações do objeto gerador de Curvas, para que possa gerar curvas a partir de duas sonoridades distintas. No caso, temos mais duas entradas 
para as listas da segunda sonoridade. A sonoridade que se mantém fixa é a "B" (inlets do meio), enquanto a sonoridade "A" é transposta da mesma maneira que antes. Um último objeto foi desenhado para que fosse usado com o objeto [Pitch-Commonality]. Como esse objeto possui uma estrutura de comparação, precisamos apenas enviar uma sonoridade, e não díades. Veja as duas adaptações na figura abaixo.
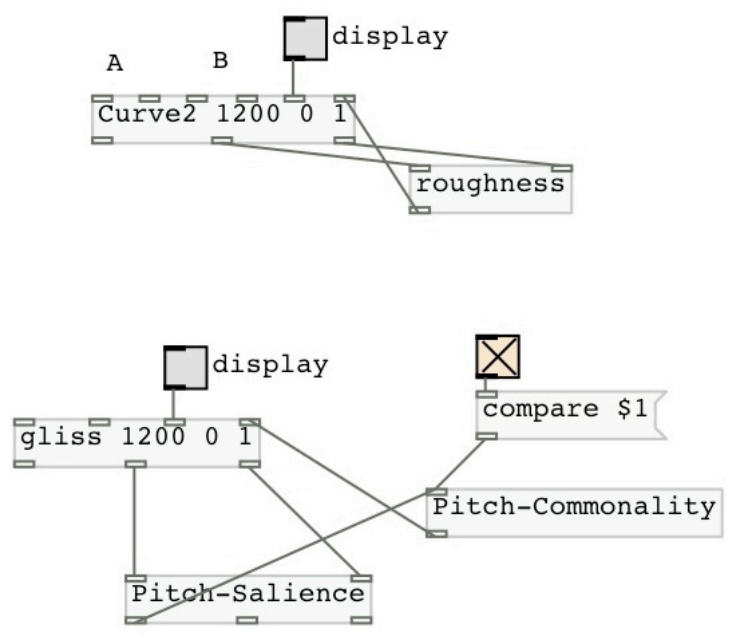

Figura 66 - Adaptações da abstração [Curve].

No objeto [gliss], o tom fixo é o que permanece armazenado, enquanto as sonoridades de entrada são transpostas da mesma maneira. Outro modo de entender esse processo é que essa sonoridade faz um glissando. Para comparar sonoridades diferentes, não necessitamos de uma adaptação, basta armazenar a sonoridade "B", que se mantém fixa no objeto [Pitch-Commonality], enquanto uma sonoridade " $A$ " faz o glissando.

\section{6 - Autotuner e Gerador de Escalas}

Para finalizar a abordagem das ferramentas básicas desenvolvidas na pesquisa, temos duas abstrações: uma é um gerador de escalas e outra, um corretor de afinação chamado de Autotuner ${ }^{31}$ - de acordo com uma escala dada. Estas são ferramentas úteis para algumas aplicações que temos visto, como o Mapeamento Espectral, já que esse módulo responde à entrada de uma escala, e também porque geramos escalas a partir de espectros e implementamos patches de mudança de altura e harmonizadores.

A figura a seguir contempla algumas dessas capacidades. $\mathrm{O}$ gerador de escalas

31 Que não diz respeito ao “autotuner” previamente mencionado na seção de Vocoder. 
cria uma divisão da oitava em 13 passos iguais. Inserimos essa escala no módulo de mapeamento espectral, que manipula os parciais de acordo com a escala. Após esse estágio, geramos uma curva de Aspereza. A expectativa é que os pontos mínimos encontrados estejam de acordo com uma divisão da oitava em 13 partes. Por fim, inserimos no Autotuner o valor de 700 cents, que é uma quinta justa no temperamento igual. Pedimos então que o corretor de afinação mude para o intervalo consonante mais próximo, de acordo com a escala dada pela curva. Eis que o intervalo mais próximo acusado é de 738 cents, que corresponde exatamente à quinta da escala da divisão igual da oitava em 13 partes. Por fim, usamos a abstração de [pitch-shift], baseada em Phase Vocoder, como um harmonizador.

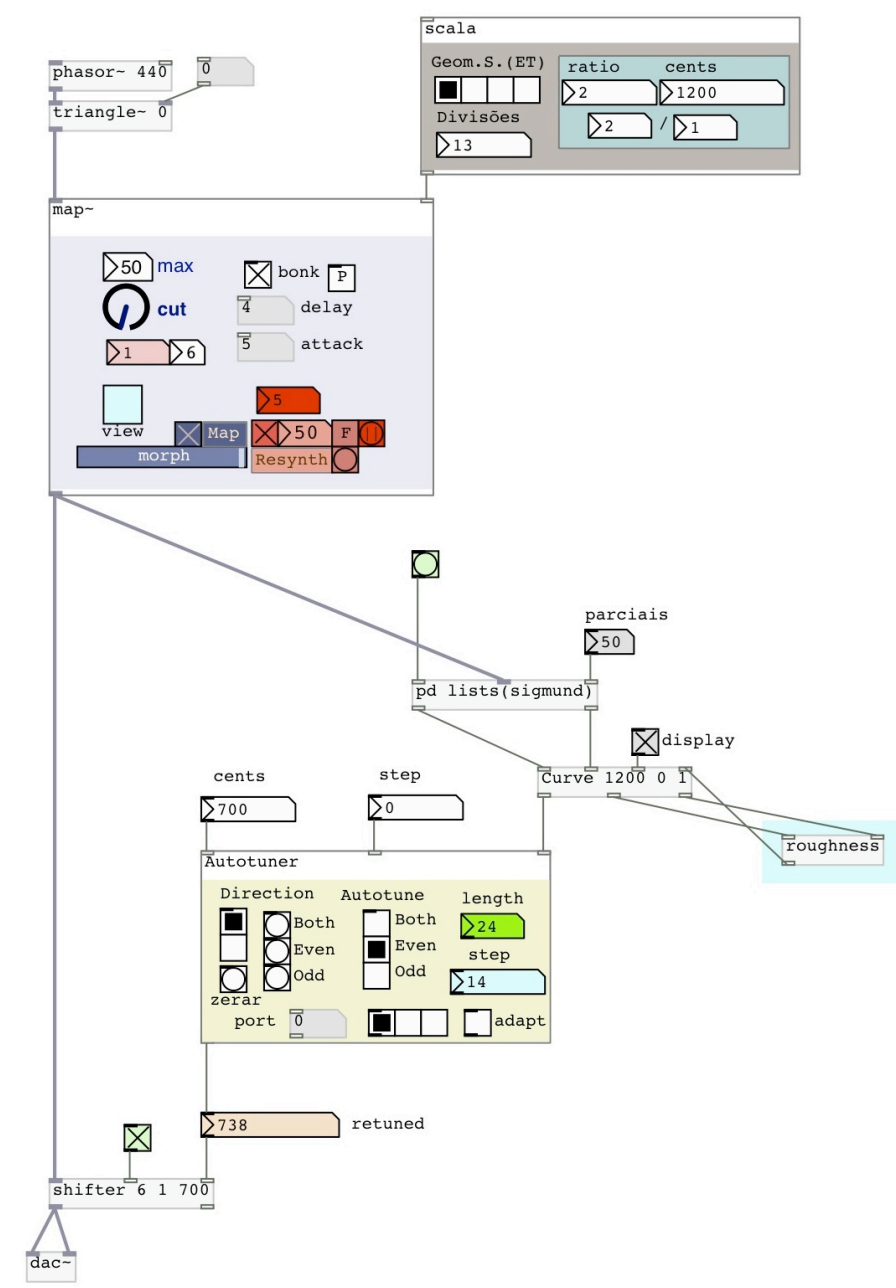

Figura 67 - Integração de Mapeamento Espectral, Gerar escala de Espectro por meio de Curva de Aspereza, Autotuner e Pitch Shifter.

Essas duas abstrações possuem diversas funções avançadas, descritas com mais detalhes no próprio arquivo de ajuda. As escalas geradas podem dividir qualquer 
intervalo (não só a oitava) de diferentes formas e não apenas em passos iguais. É possível também importar escalas no formato .scl, do software Scala ${ }^{32}$, que é uma plataforma específica para construção de escalas e já vem com um banco de dados de mais de quatro mil escalas. Já a abstração de reafinação automática permite navegar pela escala dada, reafinar para o mais perto acima ou abaixo e possibilita uma correção em glissando/portamento, ou automática, dentre outros.

Praticamente todas as ferramentas apresentadas aqui foram integradas em um único sistema, compacto e condensado, chamado [Brane ]. Este será descrito no capítulo seguinte. Claramente, algumas possibilidades de combinação dos módulos desenvolvidos não foram consideradas, apenas as mais pertinentes. Essas duas abstrações aqui apresentadas são exemplos de elementos que foram incorporados no sistema com algumas funcionalidades a menos, com o intuito de simplificação, dado a complexidade que o sistema adquiriu.

Em compensação, novos potenciais emergiram da combinação desses elementos em um sistema único. E, em todo caso, os módulos desenvolvidos ainda permanecem de modo independente com eventuais funcionalidades avançadas. De tal modo, uma busca de novas estruturas e patches a partir desses elementos continua possível, até mesmo em combinação com o sistema desenvolvido apresentado a seguir.

32 Disponível em: $<$ http://www.huygens-fokker.org/scala/>. 


\section{Capítulo 11) [Brane ] Um Sistema para Interação em Tempo Real Desenvolvido em Pure Data}

[Brane $]$ é um sistema interativo em tempo real que comporta praticamente todas as ferramentas desenvolvidas durante a pesquisa. $\mathrm{O}$ sistema foi desenvolvido $\mathrm{e}$ implementado como uma abstração de Pure Data na maior parte com objetos nativos, o que o torna muito compatível, aberto e acessível.

A junção de todas essas ferramentas resulta em uma conveniente soma de potencialidades disponíveis em apenas um único módulo, que permite não somente o uso de algumas capacidades em separado, mas também certas aplicações específicas que emergem do cruzamento de alguns de seus elementos.

A melhor forma de demonstrar suas potencialidades não é através deste texto, mas sim a partir de um manual detalhado que acompanha o lançamento deste programa, assim como um tutorial demonstrativo em vídeo que exemplifica sua utilização em tempo real. Neste texto, apenas apontamos suas características principais.

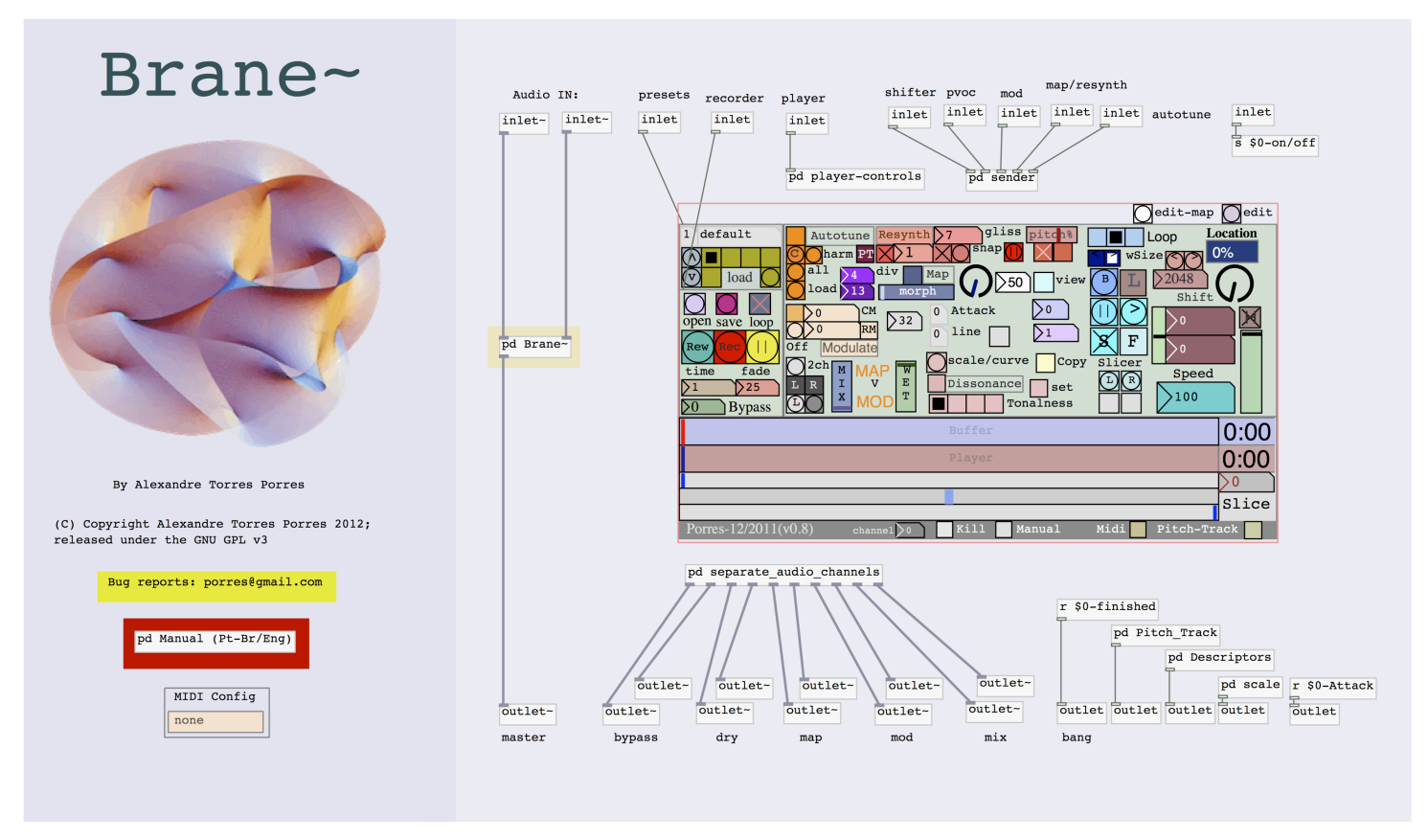

Figura 68 - Tela interna da abstração [Brane ].

O nome é uma referência a "P-branas", conceitos da teoria M (substituta da teoria das supercordas na física moderna) que dependem de um modelo do universo 
com até 10 dimensões de espaço e uma de tempo. O logotipo é uma figura de CalabiYau, que representa espaços curvados em dimensões extras. A inspiração poética para a adoção dessa referência é uma alusão a uma ideia de o sistema operar em diversas dimensões de espaço e tempo em um sinal sonoro.

\section{1 - Resumo do Sistema}

A Figura abaixo apresenta uma organização geral do subpatch [Brane ]. A estrutura básica da abstração inclui os seguintes elementos:

- Sampler com capacidades flexíveis de gravação e leitura;

- Compressão e expansão de Tempo;

- Mudanças de Altura (Pitch Shiffting);

- Harmonizer;

- Pitch Tracking e imitação melódica;

- Autotuner;

- Modulações de Amplitude;

- Ressíntese com controle arbitrário de parciais;

- Mapeamento Espectral;

- Descritores e Curvas de Dissonância.

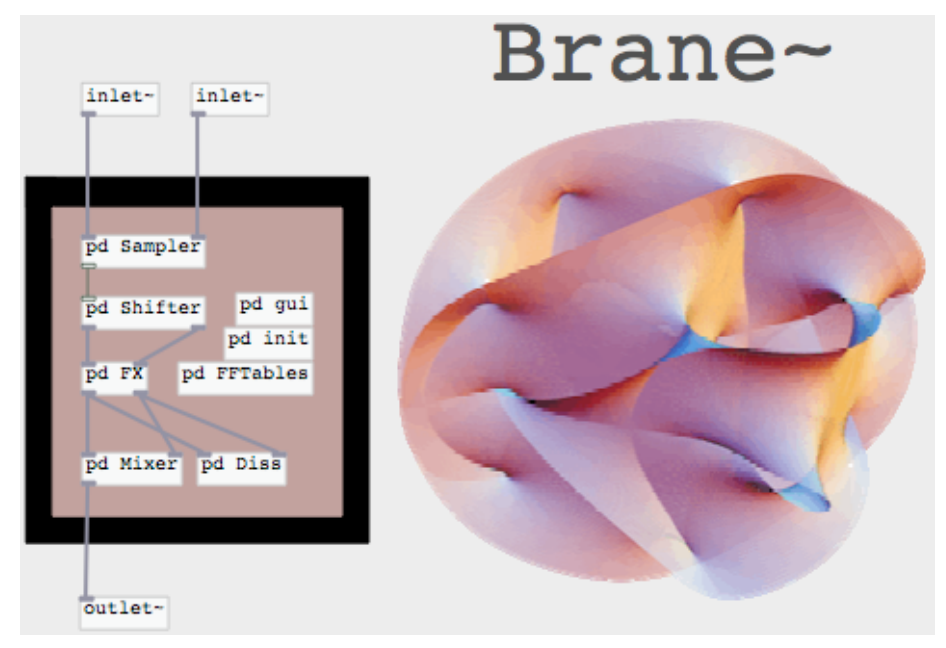

Figura 69 - Estrutura do [Brane $]$.

A base inicial do sistema é um sampler (primeira caixa de cima para baixo na Figura 69). O sampler carrega arquivos mono ou estéreo, e também grava uma entrada de áudio em um ou dois canais. Uma segunda base é o Phase Vocoder, que permite a leitura do áudio em diferentes velocidades sem interferir na mudança de Altura. Além disso, há diversos outros controles de leitura.

O Phase Vocoder também permite alterar a Altura de modo independente (ou seja, pitch shift, que é a próxima caixa na figura acima). Veremos algumas outras 
possibilidades com essa técnica, como um harmonizer e reafinações automáticas (Autotuner), pois o sistema pode carregar escalas, ou ainda ser alimentado com um gerador de temperamentos iguais embutido.

[Brane ] possui dois módulos de efeitos (próxima caixa "FX" na figura 69). Um primeiro de modulação de Amplitude (Clássica, em Anel, e Complexa), e um segundo que se trata de um módulo de ressíntese, que permite controle arbitrário de parciais, ou uma aplicação específica de Mapeamento Espectral. Por fim, temos uma mixagem final do sinal (caixa "mix"), e os dois canais de saída dessas manipulações são alimentados em descritores de dissonância em tempo real (caixa "Diss"), que, dentre outras coisas, também permitem gerar curvas para obter escalas.

\section{2 - Base do Sistema}

Todos os controles do sistema podem ser armazenados em um preset, podendo ser salvos, carregados e navegados na seção do canto superior esquerdo. Essa possibilidade faz que diversas parametrizações possam ser acessadas rapidamente, o que potencializa a maleabilidade do sistema.

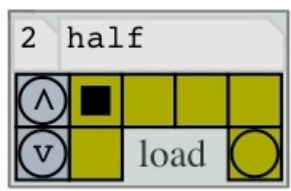

Figura 70 - banco de presets.

Outra funcionalidade não presente nos patches dos capítulos anteriores é o armazenamento de áudio em um buffer. A adoção dessa base estrutural de um sampler traz paradigmas centrais de performance, as quais descreveremos aqui, a começar pelos seus controles principais.

Os botões centrais principais são: - "Rew" (de "rewind", rebobinar), para apagar e resetar o buffer. - "Rec" (de "record") para gravar o áudio de entrada no buffer. E o ultimo botão à direita pausa e reinicia a gravação. O toggle "loop", quando acionado, reinicia a gravação do início do buffer quando ele for totalmente preenchido. O tamanho do buffer é dado em minutos na caixa de números "time". O buffer pode também ser exportado como arquivo de áudio com o botão "save". O botão "open" carrega arquivos de áudio no buffer, que é redimensionado para o tamanho dos 
mesmos. A caixa de números "fade" dá o tamanho do fade in e fade out em milissegundos, para prevenir "clicks". Por fim, um controle de Bypass permite ouvir o sinal de entrada sem que ele esteja sendo gravado.
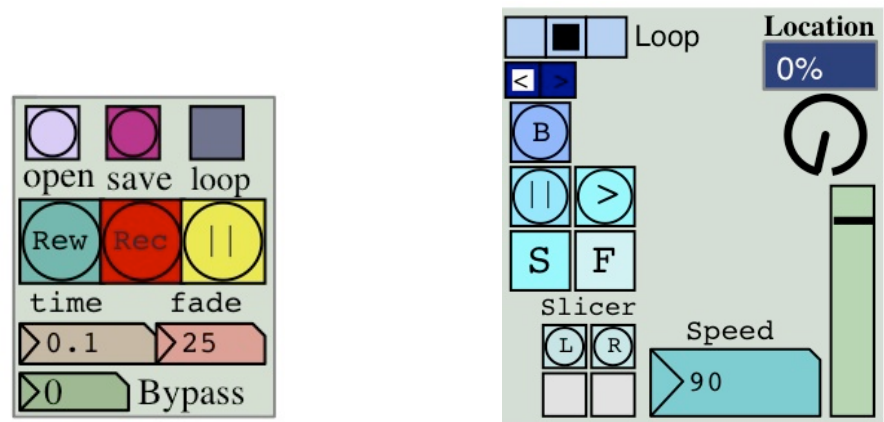

Figura 71 - Controles do buffer (esquerda) e de leitura (direita).

Quando começamos a gravar no buffer, é possível que o player comece a tocar automaticamente junto, ou então após ser acionado pelo toggle " $\mathrm{S}$ " (de start). O toggle "F" (de freeze) "congela" o áudio, o que significa que a leitura é pausada, mas ainda podemos escutá-lo. Acima, à esquerda, temos o botão “| |" de pause (ou stop), que, quando acionado, muda de estado para "go", que reinicia do ponto de parada. À direita deste, temos o botão ">" que reinicia do começo do buffer. O botão "B" (de bounce) "rebate" a direção de leitura, alterando entre o normal e ao contrário. O "horizontal radio" (caixa com três botões no canto superior esquerdo da figura à direita) permite que seja possível um loop automático ao fim do buffer, ou um bounce automático. No canto superior direito, o "location" nos mostra em que ponto de leitura estamos no buffer, dado em porcentagem, e o "knob" leva a qualquer ponto do buffer gravado. O volume geral é controlado pelo slider vertical, e o "slicer" controla parâmetros de edição que ficarão mais claros a seguir.

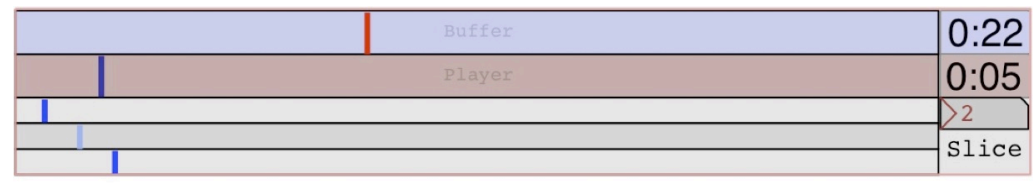

Figura 72 - Sliders de visualização do buffer.

Essa seção da interface representa o buffer de áudio, em que ponto da gravação estamos e a posição de leitura. As caixas de número à direita representam o tempo em 
minutos e segundos. Três sliders abaixo podem restringir a leitura em apenas um trecho recortado. Os botões do slicer apresentados na figura 71 marcam o ponto esquerdo (L) e direito (R) quando acionados, e os toggles desativam o recorte. É possível editar uma fatia do áudio diretamente com os sliders, e a caixa de número à direita dá um tamanho mínimo da fatia em segundos. O slider central é o ponto médio e pode ser acionado para arrastar a fatia para direita ou esquerda.

A base elementar do sistema consiste nesse sampler, que depende de um Phase Vocoder para controlar a velocidade de leitura. Apenas com esses elementos, despontam algumas aplicações criativas interessantes em tempo real, o que o torna um núcleo principal, cuja potencialidade é expandida e refinada com os frutos desta pesquisa.

A figura 73 traz a primeira versão de um Sampler e Phase Vocoder ao vivo desenvolvido durante a pesquisa, com menos capacidades de leitura e gravação. Entretanto, esse módulo relativamente simples tem sido adotado desde então como ambiente de improvisação pelo saxofonista Rogério Costa, que tem desenvolvido boas técnicas de improvisação ao vivo com o sistema elementar. Rogério Costa também é um parceiro nesta pesquisa e forma um duo de improvisação com o autor desta tese, envolvendo outras capacidades desenvolvidas durante a pesquisa.

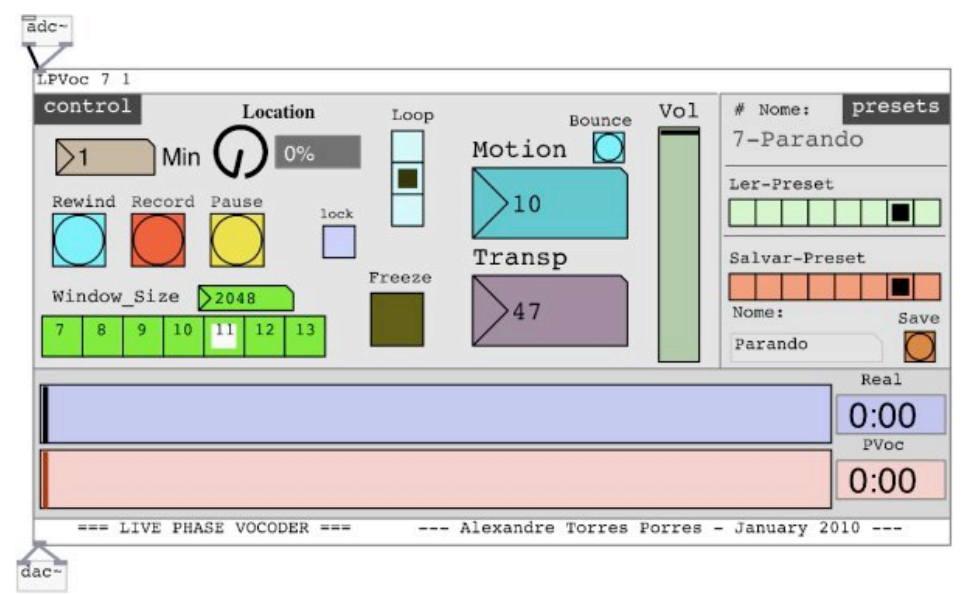

Figura 73 - Primeiro módulo de Phase Vocoder, usado por Rogério.

Ressaltamos aqui como mesmo esse módulo básico, sem as expansões com elementos da pesquisa, já traz contribuições interessantes. O ambiente permite um diálogo entre uma entrada de áudio em tempo real e sua armazenagem no buffer. Com uma velocidade de leitura apenas um pouco mais lenta, temos uma espécie de delay, 
que entra em uma defasagem maior com o tempo. É possível, assim, gerar espécies de cânones e contrapontos diversos.

O mecanismo de loop permite também manter ostinatos de base em uma camada de fundo para improvisações e contrapontos. Variações diversas são possíveis com simples mudanças de leitura em tempo real, como variação de Tempo e Altura, e também na capacidade de tocar os trechos gravados de trás pra frente. Sem contar que diferentes parametrizações estão facilmente disponíveis pela navegação de bancos de presets.

Essas características fundamentais são o cerne principal do sistema que, apesar de agregar novas funções relacionadas à pesquisa, ainda se vale desses mesmos princípios de manipulação em tempo real do buffer.

Essa unificação de um Phase Vocoder com um Sampler, apesar de relativamente trivial, não é muito comum, se levarmos em conta as diversas implementações de Phase Vocoder que estão disponíveis atualmente. A maioria opera apenas em arquivos carregados no buffer. Quando permitem gravação no buffer, há uma certa limitação de recursos em comparação à implementação desenvolvida e aqui apresentada.

\section{3 - Capacidades Avançadas}

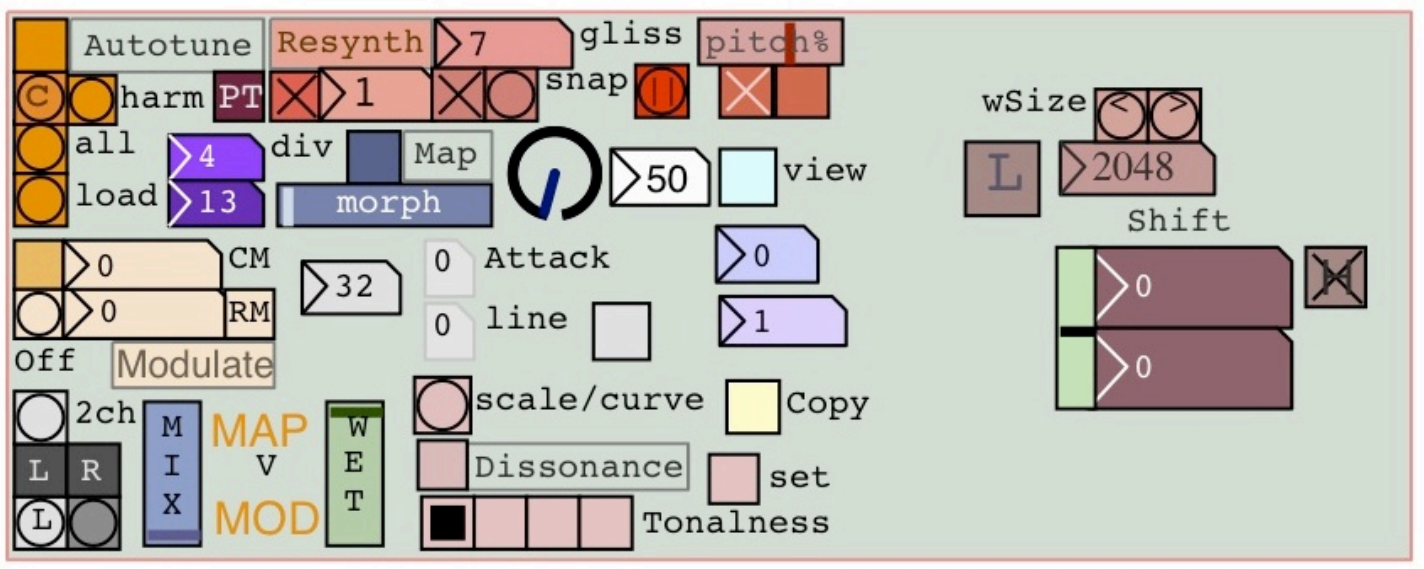

Figura 74 - Controles avançados.

A figura acima exclui os controles de leitura do buffer, apresentado na figura 71. À direita, temos controle do tamanho da janela de FFT - “wSize” (window size). O toggle "L" (de lock) é parte de uma técnica especial de trancamento de fases (phase locking), desenvolvido por Miller Puckette (1995). As caixas de número indicam a 
alteração de altura em cents, que podem atuar de modo independente, ou como um harmonizer. O slider vertical ao lado das caixas funciona como um mixer, ou "balance" entre as duas vozes na saída master.

O toggle "H" (de harmonizer), quando acionado, faz que a correção de altura não ocorra independentemente entre as duas vozes. O primeiro conceito é que a caixa de baixo diz respeito a uma fundamental e a de cima, a um intervalo harmônico. No sistema, independentemente desse paradigma e modo de operação, nos referimos sempre às caixas, respectivamente, como root e harm.

O sistema muda bastante de propriedades quando lida com sinal mono ou estéreo. Quando operamos apenas em um canal, o sinal é duplicado. A caixa de cima representa o intervalo musical (em cents) em relação ao sinal original que, por sua vez, pode ter sua altura alterada pela caixa de baixo. Mudanças na caixa inferior (root) também promovem uma alteração de Altura no sinal duplicado (harm), que mantém a mesma relação intervalar dada pela caixa de cima.

A mudança de altura de cada caixa de número é feita por um Phase Vocoder independente. Todos os módulos de efeito também são duplicados e podem ser independes para cada canal. O acesso se dá nos controles do canto inferior esquerdo da Figura 74. No caso de um sinal estéreo, o canal esquerdo é controlado pela caixa de baixo e o direito, pela de cima, mas podem igualmente operar de modo independente de acordo com o estado do toggle.

O módulo de autotune opera sobre essas caixas de números. Por meio de uma identificação de Altura obtida pelo objeto [sigmund ], é possível que uma melodia seja reafinada em tempo real de acordo com uma escala. Essa também é uma especialidade do sistema [Brane ], que não foi implementada nos módulos independentes. Essa mesma escala (ou outra) pode ser aplicada para uma afinação automática das caixas de número da Mudança de Altura.

Correções automáticas de altura podem ocorrer também a partir de modulação de amplitude, mantendo-se a mesma fundamental, como apresentado anteriormente na figura 55. Essa integração compacta é conveniente, por deixar latente diversas opções que podem ser facilmente combinadas de modo experimental.

Novamente pela identificação de Alturas, é possível uma outra particularidade do sistema, em que há a possibilidade de fazer que a linha melódica de um canal imite a melodia de outro, mesmo se esse modelo de imitação for distorcido. Porém, com a possibilidade de mudança de Alturas, é possível formar harmonias diversas, ou 
contrapontos.

Outro ponto central, como não poderia deixar de ser, é o módulo de ressíntese e Mapeamento Espectral. Uma capacidade avançada nesses sistemas permite que dois canais independentes sofram um mapeamento distinto como, por exemplo, de uma divisão igual da oitava em 7 partes em um e em 11 partes em outro.

Com a possibilidade de gerar curvas de Aspereza, é possível encontrar os intervalos em que essas duas sonoridades alinham os parciais e inserir essa escala no Autotuner, por exemplo. Essas ou quaisquer outras manipulações possíveis podem ser analisadas em tempo real para gerar curvas, ou mesmo analisar em tempo real um descritor, como o Tonalness.

A ordem dos efeitos (Ressíntese e modulação de Amplitude) pode ser invertida. Por exemplo, o Mapeamento Espectral pode ser realizado também após alguma distorção promovida pela Modulação de Amplitude, o que mantém uma mesma qualidade ou padrão espectral mesmo após uma manipulação qualquer. Mas é possível também que a fase de ressíntese venha antes e uma modulação distorça o resultado.

\section{4 - Outras Considerações}

Como previamente argumentado, entende-se que o texto de uma tese não é a melhor forma de explicar esses conceitos, que dependem de um tutorial mais detalhado e exemplos práticos para firmar ideias e possibilidades. Mas espera-se que fique claro como diversas interconexões complexas e interessantes emergem com a convergência de todas essas ferramentas em um sistema único.

O ponto final desta subseção é que há muitas potencialidades negligenciadas, que começam a surgir no desenvolvimento dessas ferramentas. $\mathrm{O}$ desenvolvimento contou com diversas descobertas e relações inesperadas ao longo do processo. O que antes era apenas um sampler integrado com um Phase Vocoder acabou se tornando um sistema bem mais complexo.

Novas potencialidades ainda estão para serem descobertas. E, como se trata de apenas uma abstração de Pd de um módulo único, ainda é possível integrá-lo a uma série de outros projetos e potencialidades enormes desse ambiente de programação para eletrônica ao vivo, além da possibilidade de se carregarem mais de uma instância desse sistema para que processe independentemente diferentes entradas.

Uma limitação desse sistema é que o seu processamento pode ser bem pesado, em especial quando se faz mapeamento espectral em dois canais independentes, a 
ponto de poder passar do limite da CPU em um macbook pro core i7 2.66 GHz. Para carregar mais de um sistema [Brane $]$, pode ser necessário adotar um recurso do Pure Data para otimizar processamento em núcleos distintos, que é o objeto [pd ].

Já para gerar curvas de Dissonância sem comprometer o fluxo de áudio no $\mathrm{Pd}$, é necessário que o processamento seja feito em outro programa Pure Data, instalado e rodando em paralelo. Para isso, um patch anexo ao [Brane $]$ de geração de curvas é oferecido para ser aberto desse modo. O controle é feito pelo [Brane $]$ normalmente, e os patches se comunicam via rede. 


\section{Capítulo 12) Considerações Finais}

Apresentamos nesta Parte II alguns exemplos da incipiente aplicação criativa da teoria psicoacústica de dissonância em composição musical. Seguimos a uma exposição de objetos e ferramentas desenvolvidas. Neste último capítulo, acrescentaremos algumas considerações para fechar esta segunda parte.

Primeiro, analisaremos algumas contribuições no principal enfoque da pesquisa, que foi o desenvolvimento de novas ferramentas para eletrônica ao vivo. Compararemos algumas contribuições em relação a um trabalho único e principal até então desenvolvido para eletrônica ao vivo, que é um pacote de objetos para Max/MSP desenvolvido por Sethares et al (2009). Em seguida, apresentaremos uma breve consideração sobre o trabalho de design e acessibilidade e, por fim, ainda outras considerações sobre fatores de menor enfoque.

\section{1 - Contribuições em Relação ao Trabalho de Sethares}

O trabalho de Sethares (1999) oferece uma profunda análise entre Afinação e Espectro Sonoro e nos oferece ferramentas e técnicas para manipulação sonora baseadas na fisiologia da escuta. Porém, o autor somente trabalha com a Aspereza e não se volta a outros elementos pertinentes da Psicoacústica em relação à percepção de Dissonância.

A maior contribuição de Sethares (1999) foi a geração de escalas a partir de espectros e o inverso (a técnica de Mapeamento Espectral), que consiste em realizar uma manipulação espectral para que uma sonoridade seja compatível com uma escala qualquer. Todavia, essa compatibilidade é apenas em termos de alinhamento dos parciais. Um Mapeamento Espectral feito a partir de uma escala ou Sistema de Afinação com alto grau de inarmonicidade pode gerar sonoridades igualmente inarmônicas. Consequentemente, o resultado promove um baixo Tonalness, uma menor Saliência de um Baixo Fundamental e uma menor Comonalidade de Altura.

As ferramentas desenvolvidas em nossa pesquisa nos permitem analisar o resultado por esses diferentes aspectos. Uma ferramenta de Análise importante são as Curvas de Dissonância, que normalmente figuram apenas como curvas de Aspereza, como no caso de Sethares (1999). Uma questão é que a teoria Psicoacústica ainda não nos informa, para uma medida de dissonância geral, como se dá a relação entre os diferentes atributos apresentados nesta pesquisa. Retomaremos a discussão teórica na 
parte final, onde faremos uma revisão crítica a respeito desse problema, e levantaremos algumas considerações e propostas de trabalho.

Com o Mapeamento Espectral, somos capazes se explorar afinações alternativas com um novo material, de forma que os Batimentos e a Aspereza são eliminados. A técnica faz que afinações com fortes relações inarmônicas - como uma divisão da oitava em 11 ou 13 partes iguais - possuam uma nova qualidade melódica/harmônica, de forma que uma linguagem tonal diferente da tradicional pode ser desenvolvida. Sethares (1999) explora algumas propriedades de um sistema com a divisão da oitava em 10 partes iguais, por exemplo.

Além do trabalho desse autor, pouco desenvolvimento tem ocorrido a partir dessas novas técnicas. É um processo musical muito interessante, mas a teoria envolvida não é trivial. Outra questão é que Sistemas de Afinação alternativos requerem um novo paradigma de interface e novas técnicas de execução, além de uma ferramenta computacional amigável e bem difundida.

Em seu livro, Sethares adotou processos de síntese como exemplo. Apenas em um sistema de Eletrônica ao Vivo (Sethares et al. 2009) é que podemos nos valer de uma riqueza sonora maior, a partir de manipulação de uma execução de instrumentos musicais em tempo real.

$\mathrm{Na}$ mesma página da internet que oferece essas ferramentas ${ }^{33}$, também se encontra uma série de sintetizadores virtuais, capazes de modular o Sistema de Afinação concomitantemente a uma respectiva modulação do espectro sonoro. Esse conceito se baseia no Mapeamento Espectral, mas é chamado de Tonalidade Dinâmica.

A respeito da problemática de interface, há um investimento na produção de novos controladores em um sistema bidimensional de navegação das notas. Esse sistema permite que vários tipos de afinação sejam acessados pelo mesmo paradigma de navegação/dedilhado, e as ferramentas computacionais também se baseiam nesse paradigma, como um Sequenciador MIDI que adota esse padrão ${ }^{34}$. De qualquer modo, esses esforços ainda são incipientes e envolvem um investimento grande de aprendizado, com um retorno ainda não muito claro do ponto de vista criativo. A técnica e a teoria precisam ser ainda mais difundidas, novas ferramentas devem ser criadas, análises críticas de um ponto de vista musical e composicional devem ser feitas, relatadas e discutidas, para que então possam ser criados mais frutos e 
desdobramentos desses primeiros esforços.

Esta tese colabora nesse sentido com a criação de novas ferramentas, e a discussão de uma reorganização e ampliação do quadro de modelos com a inclusão de outros atributos perceptivos, além da relação com outras formas de aplicação criativa, por meio do paralelo com os exemplos do trabalho de composição de Clarence Barlow e Sean Ferguson e também com desenvolvimentos na área de Descritores de Áudio. As ferramentas desenvolvidas não se fecham apenas a essa questão especializada da Afinação e buscam uma maleabilidade para que novos processos sejam desenvolvidos a partir do estudo e experimento com esses elementos.

As ferramentas de Mapeamento Espectral de Sethares possuem essa limitação de se configurarem como ferramentas relativamente fechadas, dedicadas a um único aspecto e especialidade: o de ajustar um espectro e sua melodia de acordo com um novo sistema de afinação. Dessa maneira, sempre se busca um acordo e consonância. O mapeamento se dá para um espectro harmônico, ou uma divisão igual da oitava. Já nosso trabalho traz algumas expansões e novas possibilidades com as ferramentas aqui apresentadas.

Permitimos um maior controle de como o mapeamento pode ocorrer, se todos os parciais devem ser relocados, ou apenas os que se encontram em um raio de proximidade. As escalas nas quais podemos mapear os espectros podem ser das mais distintas. Não nos atemos apenas a divisões da oitava, ou divisões iguais da oitava, mas a um gerador de escalas que permite diferentes tipos de divisão e de qualquer intervalo musical. Além da possibilidade de importar do software Scala. Por fim, apenas alguns poucos intervalos podem ser inseridos, de modo que apenas alguns parciais sejam relocados.

Os módulos de reafinação automática e harmonizador permitem também que um dado mapeamento espectral seja tocado em uma outra escala qualquer, ou que uma escala qualquer seja aplicada para uma entrada sonora que não obteve nenhum mapeamento espectral. Diversas mudanças são possíveis em tempo real, onde se permite passear por essas distintas opções. Assim como um slider de "morph" permite alternar continuamente entre o som original e o som manipulado.

Fora essas capacidades estendidas de modulação, as escalas geradas a partir de espectros também possuem passos com pontos máximos de dissonância, e não apenas consonância como é o paradigma de Sethares. A adoção de outros atributos perceptivos nos dá a opção de também atentar para como as qualidades tonais estão 
sendo manipuladas, através do descritor de Tonalness e de Comonalidade de Altura.

Por fim, o sistema [Brane ] traz ainda mais possibilidades na integração de diversas ferramentas apresentadas na pesquisa. Além de todas as capacidades já descritas, é possível também que uma sonoridade seja reafinada, harmonizada e, ainda, transposta. Mais que isso, sua estrutura também permite a manipulação de duas entradas sonoras distintas, que podem sofrer alterações diferentes e mesmo assim encontrar pontos máximos e mínimos de acordo. Isso sem contar o fato de sua base ser um sampler com diversas formas de controle de gravação e leitura, que permitem também mudanças de tempo, direção, loops, dentre outros.

Diversas manipulações avançadas do [Brane ] - que envolvem compressão e expansão espectral, controle arbitrário dos parciais na ressíntese, modulação de amplitude e convolução - podem ser controladas em tempo real e, posteriormente, mapeadas para um dado modelo de espectro. Ou, invertendo o processo, um espectro mapeado pode sofrer futuras manipulações e, mesmo assim, ainda gerar uma escala a partir do seu espectro. A geração de escalas pode também ser feita de acordo com dois espectros distintos.

\section{2 - Design e Acessibilidade}

Um objetivo desta pesquisa é produzir ferramentas e uma revisão crítica da teoria e seu impacto, para que esse conhecimento e dispositivos estejam disponíveis a músicos e compositores em geral, em sistemas de fácil acesso e interação como o Pure Data. Inclusive, muito da teoria e pesquisa psicoacústica implementada se encontra em um formato de difícil acesso para músicos em geral, e muitas vezes até mesmo fora de alguma aplicação de interesse musical.

Buscou-se uma ferramenta aberta e gratuita de eletrônica ao vivo: o Pure Data. Esse ambiente nos permite gerar interfaces gráficas amigáveis, com sliders, caixas de números, botões e afins. Esse tipo de plataforma possui um apelo de maior acessibilidade que um ambiente de programação em texto e, ainda, que uma ferramenta como o MAX/MSP, a qual requer compra de uma licença de uso. Antes de entrar no mérito de uma discussão sobre ferramentas livres, a intenção é afirmar o motivo de tal escolha, que visa uma maior disseminação.

O uso de objetos externos no Pd é trivial, qualquer usuário iniciante consegue carregar objetos já compilados em seu sistema. Mas, o desenvolvimentos de patches torna a ferramenta mais maleável, editável. Portanto, implementamos os modelos 
psicoacústicos em versões de objetos externos e também abstrações (patches) como forma de torná-los ainda mais acessíveis. A adoção de objetos externos é visada apenas quando imprescindível. No caso, algumas aplicações e funções só foram possíveis de implementar na forma de objetos novos codificados. O processamento também é mais rápido na forma de objetos, o que tornou seu desenvolvimento essencial em alguns casos.

A seguir, algumas considerações em relação às outras ferramentas mencionadas na pesquisa. Sobre as ferramentas de CAC, o AUTOBUSK (Barlow 1990), está disponível em um formato arcaico, que praticamente depende de uma emulação de sistema ATARI. E seu sistema é especializado para uma técnica e sistema próprio de composição musical. O Dissonometer também é de difícil acesso, pois está programado em Pascal. Nesta pesquisa, nem chegamos a rodar o programa no seu original, apenas adaptamos o código para ser implementado como objeto de $\mathrm{Pd}$. O sistema Apprentice (Ferguson 2000), em Open Music, é mais acessível nesse sentido. Trata-se de um sistema interessante de composição, distribuído gratuitamente, que pode ser um interesse futuro de implementação de nossa pesquisa.

A respeito das ferramentas de descritores de áudio, o software SPORCH é mais aberto, porém menos amigável que o Orchidée, pois necessita de conhecimento de programação e compilação de códigos. O Catart roda em MAX/MSP, mas é distribuído livremente. Sua estrutura, porém, é complexa e possui algumas dependências externas. O objeto [TimbreID] uma solução mais simples e com menor margem de problemas, com uma curva mais rápida de aprendizado.

Nosso processo de desenvolvimento culminou em um patch de Pd chamado [Brane $]$, um sistema que incorpora os vários patches desenvolvidos durante esta pesquisa. Esse sistema está acessível em uma interface amigável. Porém, suas funcionalidades são muitas, o que pode tornar seu uso nada trivial em um primeiro momento de contato.

Por isso, é importante também a exposição dos patches e módulos independentes, de modo que cada potencialidade criativa da teoria seja compreendida e absorvida em paralelo, para que depois se encontrem novas potencialidades na junção desses mesmos elementos. Claramente, este texto possui outro papel importante complementar, na exposição da teoria e revisão crítica de vários aspectos desses sistemas. 


\section{3 - Outras Considerações}

A aplicação dessa teoria tem tido destaque no desenvolvimento de aplicações em afinação e escalas. Nosso foco acabou também pendendo para uma experimentação e desenvolvimento de ferramentas nesse sentido, que já nos dá diversas possibilidades de futuras pesquisas. Nesse nicho de maior enfoque, apontamos aqui algumas das alternativas. Muitas delas emergiram inesperadamente no processo de experimentação laboratorial, sendo constantemente implementadas. Novas ideias surgiam a partir de uma perspicácia decorrente de uma melhor noção da potencialidade criativa, obtida por um olhar compenetrado durante a pesquisa.

Apresentamos aqui o resultado atual de muitas ferramentas, mas entendemos que elas devem se desenvolver ainda mais em trabalhos futuros. Logo, o resultado atual é apenas um primeiro estágio de evolução. Primeiras versões e protótipos puderam ser desenvolvidos nesse tempo em que também nos voltamos a uma pesquisa teórica e considerações críticas sobre o papel e relevância desse trabalho sob um ponto de vista criativo.

As possibilidades aventadas não são poucas, nem simples. Mesmo no nicho de maior enfoque, não pudemos explorar todas as capacidades das ferramentas desenvolvidas de forma criativa. O sistema foi adotado em uma peça para orquestra e em processos de eletrônica ao vivo, que serão discutidos na parte final, em uma última exposição e revisão crítica do potencial criativo das teorias estudadas.

Também ressaltamos o papel de modelos de dissonância em processos composicionais assistidos por computador. As ferramentas desenvolvidas também permitem processos similares, apesar de se encontrarem em um sistema dedicado para eletrônica ao vivo, o Pure Data. Mas, esse mesmo sistema é capaz de processos similares, onde podemos medir e comparar qualidades sonoras. Um exemplo é o objeto [Pitch-Commonality], capaz de organizar e comparar diferentes sonoridades, sejam acordes ou tons, harmônicos e inarmônicos.

O Pd pode não ser o melhor ambiente para um processo de composição algorítmica ou assistida por computador, mas ele pode servir, em parte, para isso e ainda prover uma espécie de meio termo, que lhe permite, concomitantemente, ainda usufruir de sua estrutura de Eletrônica ao Vivo.

As próprias Curvas de Dissonância ainda não são capazes de serem processadas em tempo real. Elas se configuram como uma espécie de descritores para intervalos musicais, e foram exploradas e discutidas neste trabalho. Para dar conta 
desse processo em performance, o [Brane $]$ conta com um método de conexão via rede entre duas instalações diferentes de Pure Data, para que o áudio não seja interrompido pelo processo. Mesmo assim, ocorre uma certa latência e espera de retorno dos dados.

Incluímos também no debate alguns avanços na área de Descritores de Áudio. $\mathrm{Da}$ mesma forma que em processos de CAC, encontramos uma relação que deve ser melhor explorada entre os frutos de nossa pesquisa e os processos criativos em Descrição de Áudio, como a Síntese Concatenativa.

Há muita semelhança entre a estrutura de comparação do objeto [TimbreID], de William Brent, e o objeto [Pitch-Commonality]. Ambos comparam similaridades entre o espectro de duas sonoridades, sendo que o [TimbreID] foca em uma semelhança em relação ao timbre, enquanto o [Pitch-Commonality] em uma semelhança de percepção de Altura.

No sistema [Brane ] também é possível, por meio de identificação de Alturas (um processo de descrição de Áudio), modular uma entrada melódica para que imite outra, ou ainda uma sequência dada. Entendemos que esse tipo de processo deve fazer parte das ferramentas e processos aqui apresentados. Há ainda muitos avanços que podem ser feitos em relação aos Descritores de Áudio e métodos comparativos de CAC.

Tais desdobramentos devem emergir com um amadurecimento desse trabalho, em que um olhar mais aprofundado ajudará a criar novas relações em um processo laboratorial de experimentação semelhante ao dos resultados já apresentados. Retornaremos a essa discussão na próxima parte junto com um debate sobre o impacto dessas ferramentas em eletrônica ao vivo e composição musical. 


\section{PARTE III) Discussão Final}

\section{Introdução:}

Antes de apresentarmos a conclusão, temos dois capítulos finais que trazem uma discussão sobre os problemas encontrados durante esta pesquisa. O capítulo 13 retoma a discussão teórica psicoacústica e tem como objetivo principal discutir as Curvas de Dissonância. Já o capítulo 14 discute o impacto da teoria psicoacústica em composição musical. 


\section{Capítulo 13) Discussão Teórica Crítica}

Retomaremos neste capítulo a revisão teórica na área de Psicoacústica e proporemos uma nova forma de organização dos atributos perceptivos estudados, assim como uma revisão do conceito de Curvas de Dissonância, a partir de duas dimensões perceptivas. Um teste psicoacústico também é apresentado para ajudar na investigação, antes de apontarmos considerações finais e perspectivas futuras. A maior dificuldade é a unificação de diferentes atributos apresentados anteriormente em uma percepção geral de Dissonância.

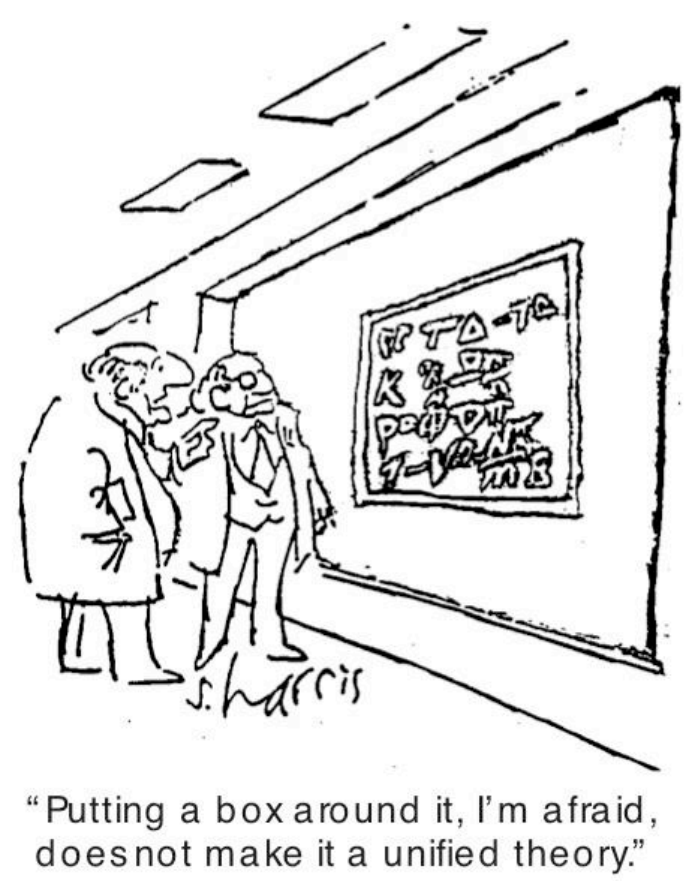

"Receio que colocar uma moldura em volta não a torna uma teoria unificada" Tira cômica de Sidney Harris ${ }^{35}$

\section{1 - Recapitulação da Teoria Psicoacústica}

A Aspereza tem sido encarada como a mais importante dimensão da dissonância sob um enfoque psicoacústico, que surge sob a terminologia de Dissonância Sensorial e se aplica a qualquer sonoridade. Essa característica da Dissonância Sensorial fez que ela se tornasse um grupo sujeito à inclusão de outros dois atributos auditivos: Brilho e Tonalness.

Fora de um contexto musical, a relação entre esses três componentes foi

35

Chalk Up Another One: The Best of Sidney Harris (1992). 
estudada e medida em testes, e um modelo análogo ao conceito de Dissonância Sensorial - chamado de Sensory Pleasantness - foi proposto por Zwicker e Fastl (1999). Nesse modelo, o Brilho possui um papel importante.

Não é claro como esses três itens se relacionam em uma medida de Dissonância Sensorial em um contexto musical. Em todo caso, em vez do Brilho, a Aspereza possui um papel de destaque afirmado por Terhardt (2000b), e ferramentas atuais como a de Sethares et. al (2009) apenas adotam e consideram a Aspereza. Parncutt (1989) nem menciona o Brilho e apenas diz que a Aspereza e Tonalness são os elementos mais importantes da Dissonância Sensorial. Todavia, não encontramos dados e testes que tivessem investigado esse problema a fundo.

Veremos nesse capítulo incongruências e problemas envolvendo diferentes modelagens da Aspereza. A respeito de Tonalness, não temos os mesmos tipos de divergência, pois sua inclusão na literatura é mais recente, e as revisões feitas por Parncutt (1989) têm sido aceitas sem confronto com o trabalho original de Terhardt.

O conceito de Tonalness possui relação com outros elementos, como o Descritor de Áudio Tonality, o conceito de Fusão Tonal, e ainda alguns modelos arbitrários como o de Harmonicidade de Barlow (1980) e Entropia Harmônica de Elrich (1997). Mas, no contexto da Psicoacústica e Dissonância Sensorial, temos apenas o conceito de Tonalness (Complexo) como apresentado neste texto - e seu modelo depende do conceito de Altura Virtual.

Apresentamos duas medidas de Tonalness nesta tese: Puro e Complexo. O Tonalness Puro é uma medida relacionada com sons em um contexto não musical, que é um modelo que faz parte de Sensory Pleasantness, segundo Aures (1985a). A medida de Tonalness Puro depende apenas dos componentes espectrais, ou melhor, do Peso de Altura Espectral. Já o Tonalness Complexo é o conceito de Tonalness "por excelência", próprio da Dissonância Sensorial em um contexto musical e baseado nos Pesos de Altura Virtual, uma medida que se vale de uma busca por um padrão harmônico em uma sonoridade. O Tonalness Complexo é dado pelo maior peso de Altura Virtual, normalizado para que seu valor máximo seja aproximadamente 1.

O Peso de Altura Virtual faz parte de uma medida geral de Peso de Altura, que inclui também algum elemento do Peso de Altura Espectral, caso ele seja mais forte que o Peso de Altura Virtual. Mas, no geral, o Peso de Altura Virtual - a mesma base do cálculo de Tonalness Complexo - é um dado relevante e presente no Peso de Altura. Por sua vez, o Peso de Altura é uma base de medida para a Multiplicidade e 
redimensionado para se qualificar como Perfil de Saliências de Altura.

Portanto, o mesmo dado essencial para a medida de Tonalness (Complexo) se relaciona fortemente com o Perfil de Saliência de Altura, em que cada Saliência indica a facilidade de se perceber aquela Altura, e a soma de todas as Saliências nos dá o Valor de Multiplicidade. Com esses dados, podemos encontrar os elementos do grupo de Harmonia, que completa o quadro de atributos da Dissonância Musical. A Fundamental do Acorde, por exemplo, é dada dentre as alturas mais Salientes. E o Perfil de Saliência é o dado para comparação em um modelo de Comonalidade de Altura, que busca Saliências em comum.

\section{2 - Discussão Teórica sobre a Modelagem de Dissonância}

Levantamos aqui a questão de quanto cada atributo contribui para uma percepção de Dissonância - ou como e em que aspectos uns seriam mais relevantes que outros. O papel de destaque da Aspereza tem sido afirmado constantemente neste texto, mas questionamos até que ponto apenas esse atributo pode ser considerado. Propomos também uma nova organização em dois grupos diferentes dos da tabela 4 (que divide nos grupos de Dissonância Sensorial e Harmonia). Vide tabela abaixo.

Tabela 11. Reorganização dos Atributos Perceptivos da Dissonância Musical.

\begin{tabular}{|l|l|}
\hline Harmonicidade (Percepção de Altura): & Banda Crítica: \\
\hline - Tonalness & - Aspereza \\
- Fundamental do Acorde & - Brilho \\
- Comonalidade de Altura & \\
\hline
\end{tabular}

A relação entre Tonalness (elemento da Dissonância Sensorial) e os atributos do grupo de Harmonia (Fundamental do Acorde e Comonalidade de Altura) se dá pela medida de Peso de Altura Virtual, que serve de base para todos e depende de um padrão harmônico do espectro. Logo, todos esses conceitos se agregam em uma dimensão perceptiva geral de Harmonicidade, que se relaciona com a percepção de Altura em si ${ }^{36}$.

A Aspereza não depende de Harmonicidade nem se relaciona com a percepção de Altura, tampouco o Brilho. Todavia, ambos possuem um fator em comum, que é

$36 \quad$ O conceito de Fusão Tonal também se encontra dentro desse mesmo escopo conceitual, porém será desconsiderada pela falta de um modelo estabelecido. A Entropia Harmônica e a Harmonicidade de Barlow (1987) são outros conceitos relacionados, mas serão desconsiderados por não se tratarem de modelos psicoacústicos de fato. 
uma relação com a Banda Crítica. A Aspereza mede uma proximidade de parciais em uma banda crítica, e o Brilho é contabilizado a partir de energia existente em uma Banda Crítica.

O conceito de Harmonicidade que estamos definindo aqui está também ligado com a relação de números inteiros pequenos, pois esses são encontrados no modelo de uma Série Harmônica que, além de influencia na percepção de Altura, formam intervalos musicais justos. Esses intervalos são importantes até mesmo em sistemas temperados que, em sua maioria, são aproximações de afinações justas (Porres 2007). Nosso sistema temperado, por exemplo, possui uma boa aproximação quinta justa (3:2), em que a diferença é de menos de 2 cents.

Sobre a relação entre os três elementos da Harmonicidade, o Tonalness e a Fundamental do Acorde são, na verdade, complementares. A medida de Tonalness é o valor do maior Peso de Altura virtual, enquanto a Fundamental do Acorde é a frequência da altura mais saliente, que corresponde ao maior Peso de Altura Virtual, já que há uma forte relação entre o Peso de Altura Virtual e o Perfil de Saliência. Temos assim uma possível simplificação que incorpora esses dois conceitos em um único elemento, que fornece um dado duplo, o valor de Tonalness e sua frequência.

O Modelo de Comonalidade de Altura se destaca por único com característica comparativa, que visa dar um valor de relação harmônica entre duas sonoridades. A Fundamental do Acorde também se aplica como complemento desse tipo de medida, ao nos informar qual a frequência que emerge como Baixo Fundamental da combinação de duas sonoridades. Ambas medidas, porém, se configuram como o grupo de Harmonia segundo Terhardt (1974).

O modelo de Fundamental do Acorde pode então ser acoplado aos outros dois elementos como um dado complementar. A maior diferença entre os atributos do grupo de Harmonicidade acaba se firmando entre o Tonalness e a Comonalidade de Altura. A comparação de gráficos de Tonalness e Comonalidade de Altura já foi dada na figura 62 (página 144).

Como o problema da relação entre quaisquer atributos da tabela 1 ainda se encontra em aberto, partimos de um passo inicial para adressar essa questão e simplificamos esse quadro ao desconsiderarmos o Baixo Fundamental e o Brilho. Desse modo, teremos duas dimensões principais: a Aspereza (que já possui seu reconhecido destaque) e a Harmonicidade (como uma dimensão única). Essas dimensões serão levadas em consideração no contexto de Curvas de Dissonância. 


\subsubsection{Curvas de Dissonância em Duas Dimensões Principais}

As Curvas de Dissonância são interpretadas nesta tese como um Descritor de Dissonância para intervalos musicais. Esse é um contexto específico que trata da sobreposição de sonoridades e pode incluir todos os atributos psicoacústicos da tabela 11, que correspondem aos atributos da Dissonância Musical segundo Terhardt (1974).

Na figura 63 (página 145), vimos gráficos de Curvas de Dissonância com a exposição e comparação de diferentes atributos: a Aspereza e outros descritores de Altura (Tonalness Complexo e Comonalidade de Altura) ${ }^{37}$. A Fundamental do Acorde, ao ser aplicada às díades usadas na construção das curvas, não produz um perfil semelhante. Porém, pode ser considerada sua pertinência ao constatar que há uma maior consonância no caso do tom de base da díade ser aferido como Baixo Fundamental.

Ao analisarmos dados de medida de Brilho para Curvas de intervalos musicais, não encontramos informações significativas de mesma ordem, pois diferenças de alinhamento de parciais ou a harmonicidade do som não influenciam no seu modelo. Grosso modo, o Brilho é apenas uma medida relacionada à distribuição de energia no espectro. Ou seja, está mais relacionado com a percepção de Loudness do que com as interações ou relações entre parciais.

Dado o problema de relacionar diferentes atributos de nosso quadro, nos ateremos a uma simplificação que, a princípio, exclui o Brilho e a Fundamental do Acorde, nos deixando apenas com duas dimensões principais: Aspereza e Harmonicidade. Desse modo, temos apenas os atributos que geram linhas independentes em gráficos como o da figura 63.

O grupo relacionado à percepção de Altura/Harmonicidade mantém assim apenas dois elementos: Tonalness e Comonalidade de Altura. A diferença entre esses é que Tonalness pode ser empregado em qualquer tipo de sonoridade (Dissonância Sensorial), enquanto a Comonalidade de Altura é um descritor comparativo de Harmonia, e depende de duas sonoridades distintas. Ambos, entretanto, podem ser usados para gerar curvas com resultados similares, ou podem ainda se fundir em uma única curva de Harmonicidade. Vejamos agora uma revisão dos modelos de Aspereza antes de contrapormos essas duas dimensões principais propostas.

37 O Tonalness Puro também apareceu no naquele exemplo, mas apenas por questões ilustrativas para que seu conceito ficasse claro. Consideramos o Tonalness Puro como um conceito à parte que não se aplica nesse contexto de Curvas de Dissonância. 


\subsubsection{Revisão dos Modelos de Aspereza}

As curvas de Aspereza apresentadas na parte anterior (seção 10.5) foram geradas a partir de um modelo baseado no estudo de Barlow (2008). Apontamos como a maior controvérsia na implementação de diferentes estudos consiste em como contabilizar a Aspereza levando em consideração a diferença das amplitudes dos componentes espectrais.

O método de Barlow calcula uma média desses valores. Sethares escolhe o menor valor das duas amplitudes, procedimento igual ao modelo de Hutchinson e Knopoff (1978). Enquanto não há grandes diferenças entre esses métodos, o estudo de Vassilakis (2001) gera resultados significativamente distintos.

Essa discrepância é, na realidade, a grande contribuição e problema de pesquisa do trabalho de Vassilakis. Ele revisa e aponta inconsistências nos métodos de contabilizar a diferença de amplitude e desenvolve uma equação baseada no "Grau de Flutuação de Amplitude". Sua revisão foi inserida e adaptada no modelo de Sethares (1999).

Vassilakis (2001) desenvolveu alguns estudos para medir a sensação geral de Dissonância e a sensação de Aspereza de intervalos musicais. Não está claro como o autor define a Dissonância de um modo geral. Ele parte da noção que ela pode se relacionar com alguns atributos perceptivos, ou fatores acústicos, mas não discute quais seriam eles além da Aspereza. Vassilakis (2001) também não revisa, ou discute diferentes conceitos de dissonância no decorrer da História, como fez Tenney (1988); consequentemente, sua definição de Dissonância é simplificada e apenas afirma que há um aspecto sensorial e outro histórico/cultural.

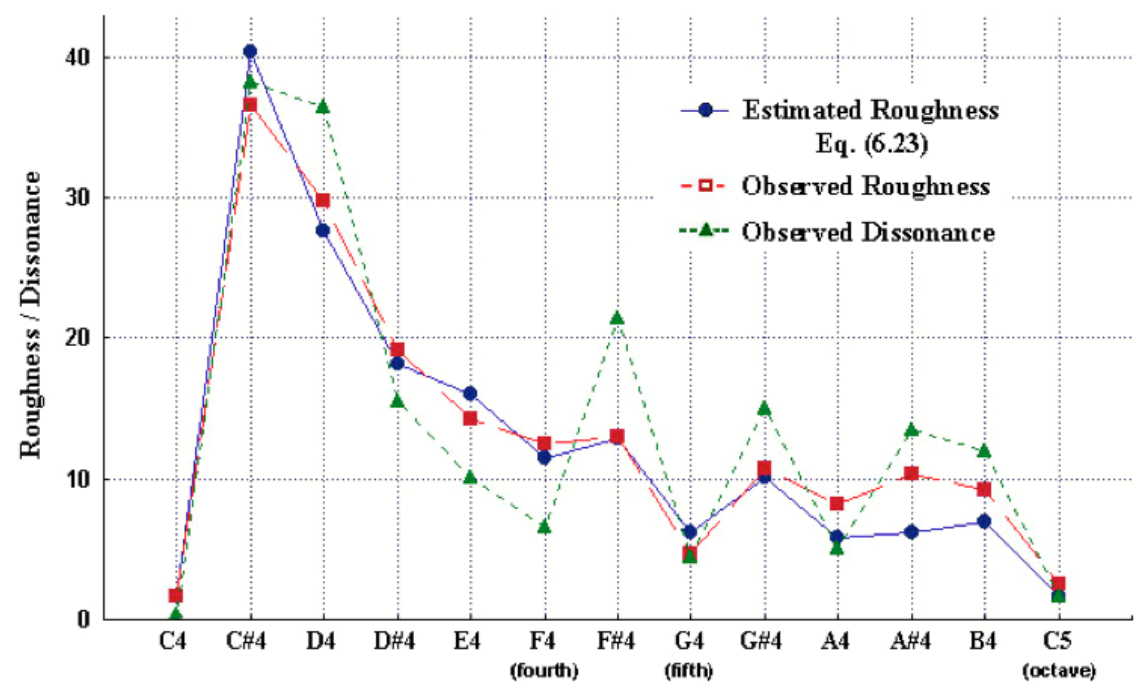

Figura 75 - Teste perceptivo de Vassilakis. 
A figura 75 compara os resultados de dois testes perceptivos desenvolvidos por Vassilakis. O gráfico possui a mesma estrutura que as Figuras 60, 62 e 63, ou seja, são curvas de Dissonância para díades no espaço de uma oitava no sistema temperado. Em verde, temos a média do resultado da Dissonância; em vermelho, a Aspereza e a linha azul é o gráfico gerado pelo modelo de Vassilakis. O estímulo usado foi uma onda dente-de-serra sintetizada, levemente inarmônica, com seis parciais. Os intervalos foram apresentados aleatoriamente.

Vassilakis definiu e treinou os participantes de seu teste a compreenderem a sensação de Aspereza como um atributo distinto, afirmando que todos foram capazes de demonstrar que incorporaram o conceito, estando aptos a aferir os resultados nos testes. Vemos uma diferença entre a Dissonância e Aspereza estimadas, sendo mais contrastante a diferença do desenho gráfico nos três pontos da quarta à quinta $(\mathrm{F} 4$ F\#4 e G4). Nas medidas de dissonância, em verde, o trítono forma um pico bem mais proeminente, não apenas por sua maior dissonância, mas também pelo fato da quarta ter sido considerada mais consonante. Os pontos de maior concordância são o uníssono, oitava e quinta, como fortes consonâncias, e o Semitom como maior dissonância.

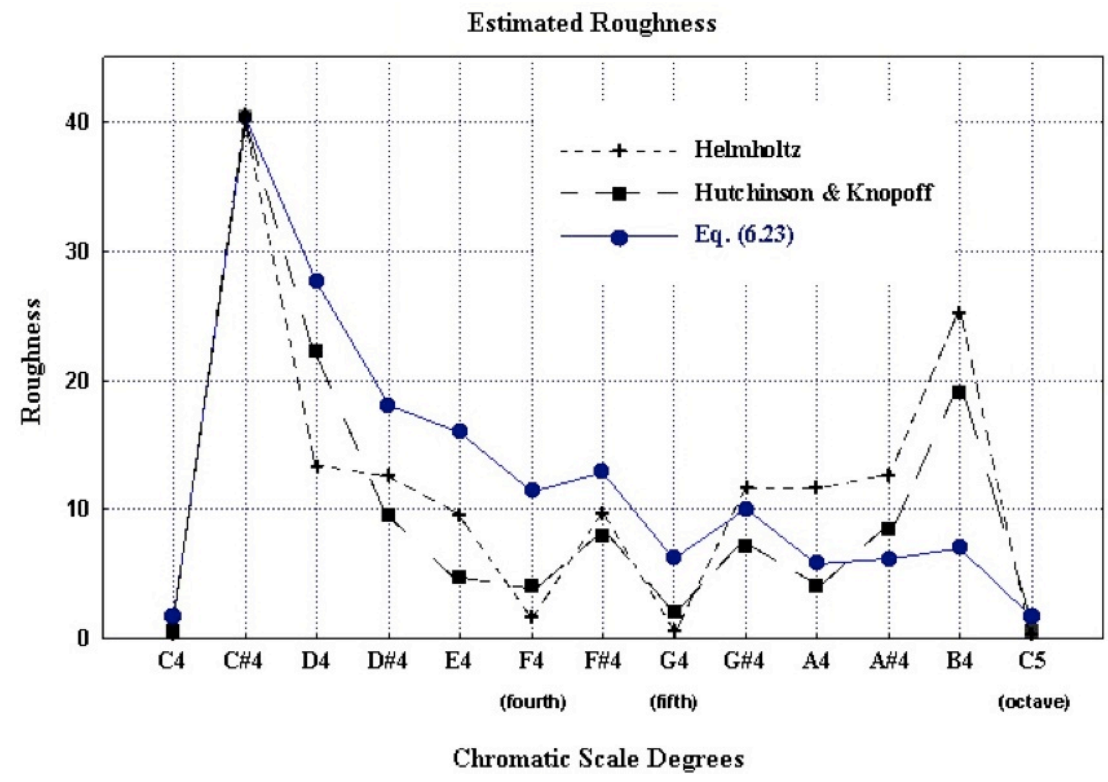

Figura 76 - Comparação de Modelos por Vassilakis (2001).

Vassilakis (2001) aponta que uma evidente presença ou falta de Aspereza contribui no julgamento de dissonância. Entretanto, em um caso contrário, o autor considera que a sensação de Aspereza não influencia mais da mesma maneira e dá 
margem para fatores de outra ordem. Porém, como o autor apenas expõe uma dicotomia entre Aspereza e critérios históricos/culturais, são esses outros fatores que ele afirma como relevantes no julgamento de dissonância. O autor valida, em sua pesquisa, o seu modelo como forma acurada de medir a Aspereza, mas seu estudo traz algumas implicações e questões por gerar resultados distintos de modelos anteriores. A figura 76 compara o resultado de seu modelo com o de Helmholtz (1877) e Hutchinson e Knopoff (1978).

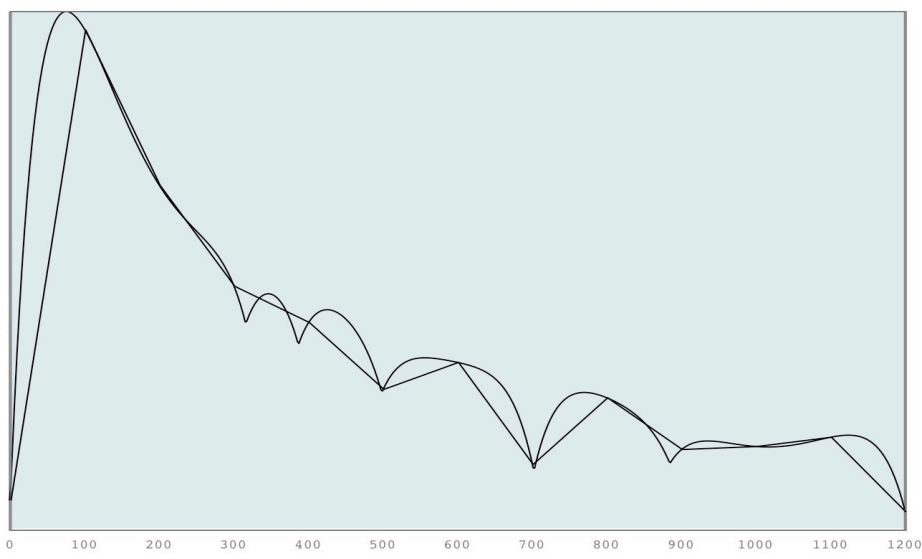

Figura 77 - Curva fornecida pelo objeto [roughness].

Com complemento, fornecemos na figura 77 o resultado dado pelo objeto [roughness] para uma sonoridade com as mesmas características no modelo de Vassilakis. Há dois gráficos sobrepostos, um é o mesmo dado na figura 76, enquanto o outro é a curva dada por uma resolução de 1 cent. É apenas com uma boa resolução de pelo menos 1 cent que somos capazes de gerar escalas a partir de espectros.

Vemos na figura 76 que a tendência dos gráficos gerados por Vassilakis é descendente, enquanto os outros modelos geram mais contrastes entre pontos máximos e mínimos. Essa mesma tendência de contrastes ocorre para os gráficos apresentados neste texto a partir a implementação do método de Barlow. Desse modo, veremos como a falta de contrastes nos resultados de Vassilakis não nos ajuda a encontrar, dependendo da sonoridade analisada, pontos máximos e mínimos da mesma forma que os outros modelos que possuem uma tendência diferente.

A figura 78 nos traz curvas de Aspereza gerada pelo objeto [roughness] com uma maior resolução (de 1 cent) nos modelos de Barlow (2008) - sem o modelo de mascaramento - e Vassiliakis (2001) para a mesma sonoridade das figuras anteriores. A linha de cima é a Curva dada pelo método de Barlow, que, como já adiantamos, 
possui mais contrastes que a Curva de Vassilakis, abaixo. Mas, no geral, o desenho de ambas curvas seguem um padrão similar.

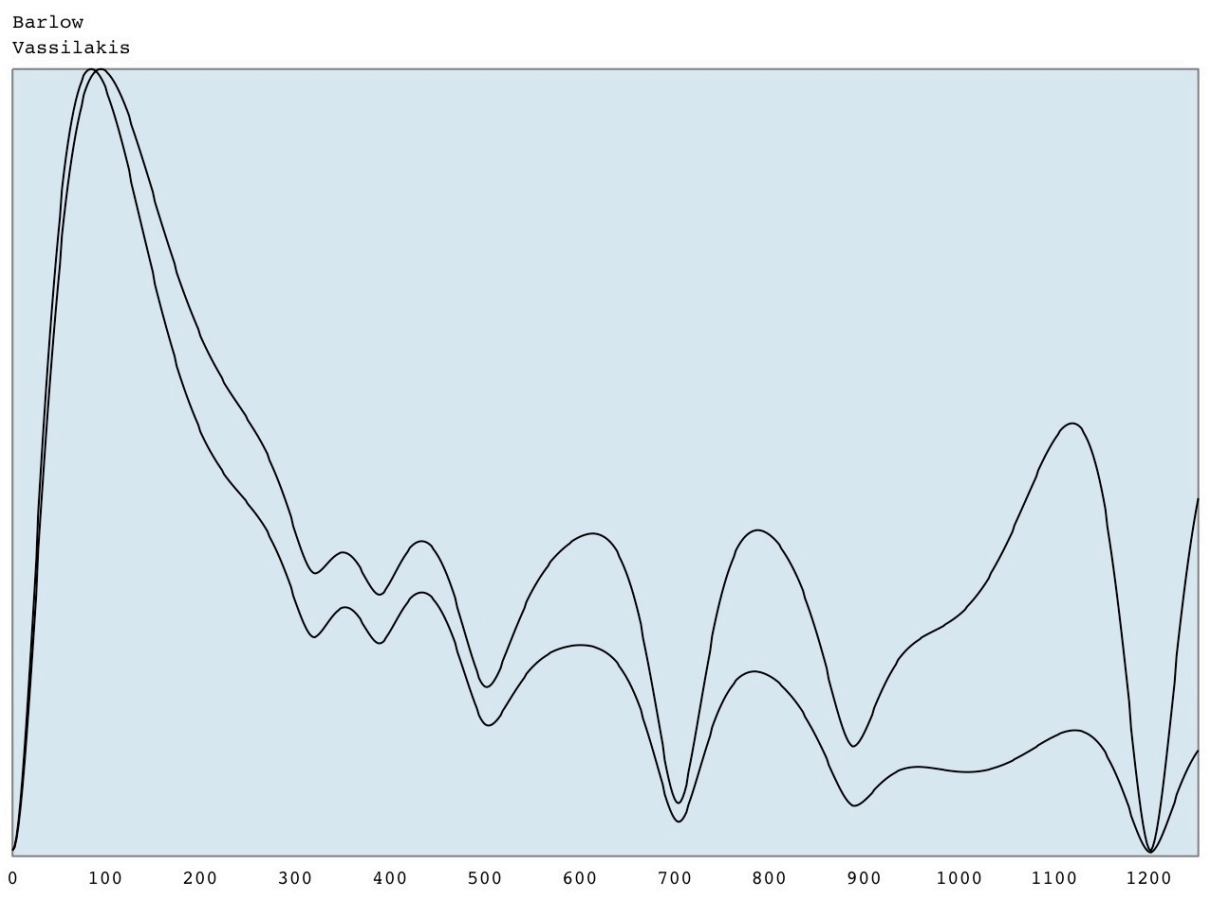

cents

Figura 78 - Barlow (acima) versus Vassilakis (abaixo).

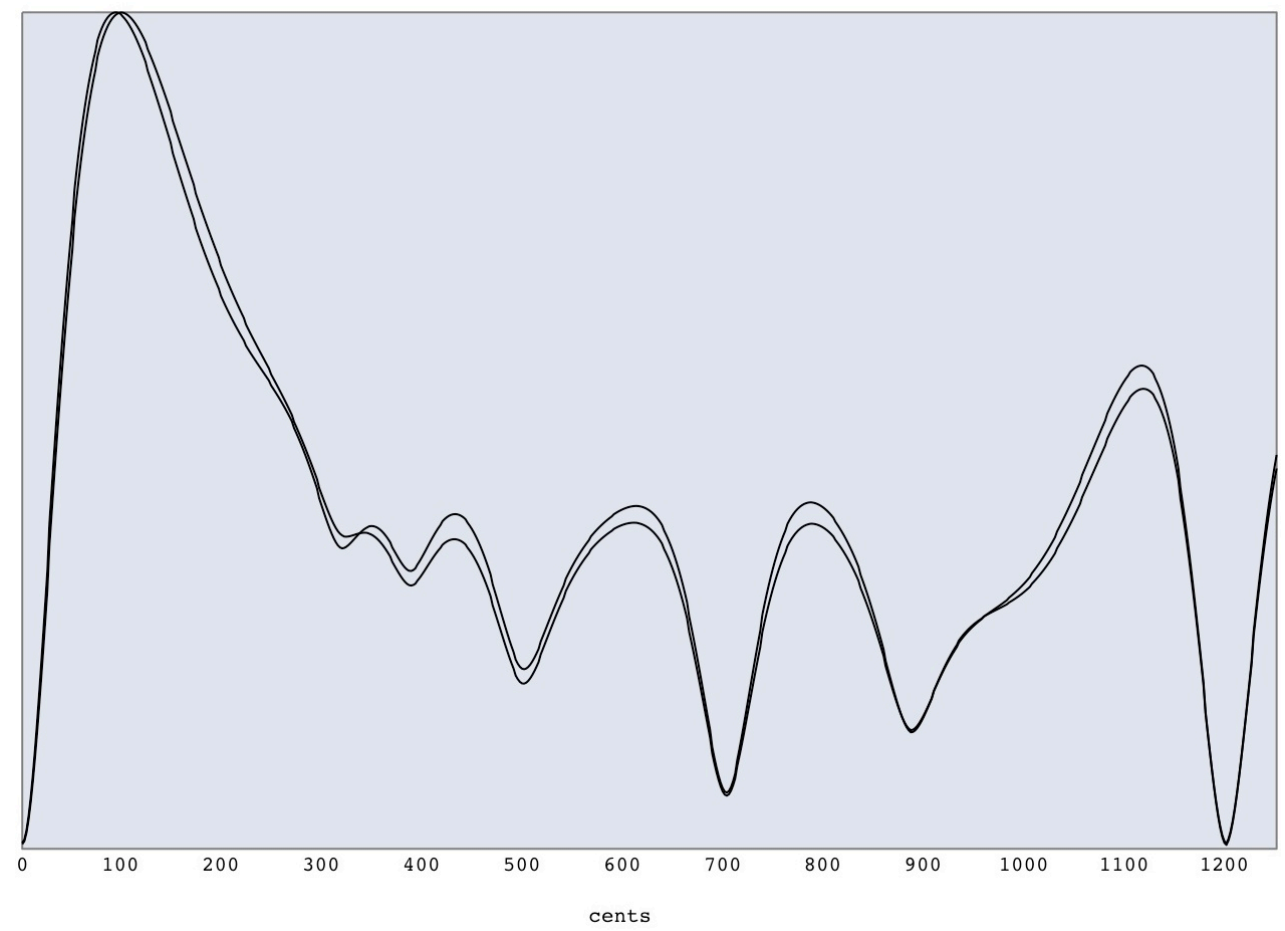

Figura 79 - Barlow com e sem Loudness. 
Comparamos agora os resultados dados pela contabilização ou não de Loudness e mascaramento. Vimos anteriormente que o passo relativo ao loudness gera bastante custo computacional. Averiguamos, assim, até que ponto esse alto custo gera uma diferença significativa. Veja na figura 79 como a diferença é realmente pequena. Portanto, descartar o de Loudness não distorce muito os dados, dependendo do registro. Barlow é o único que se preocupou em contabilizar não só o loudness, como também o mascaramento. Porém, o autor não o fez motivado por um melhor encaixe dos resultados com dados de testes psicoacústicos. Esse tipo de preocupação deve ainda ser levada em consideração em estudos perceptivos que se voltem para investigar como o Loudness e o mascaramento de fato contribuem para a sensação de Aspereza.

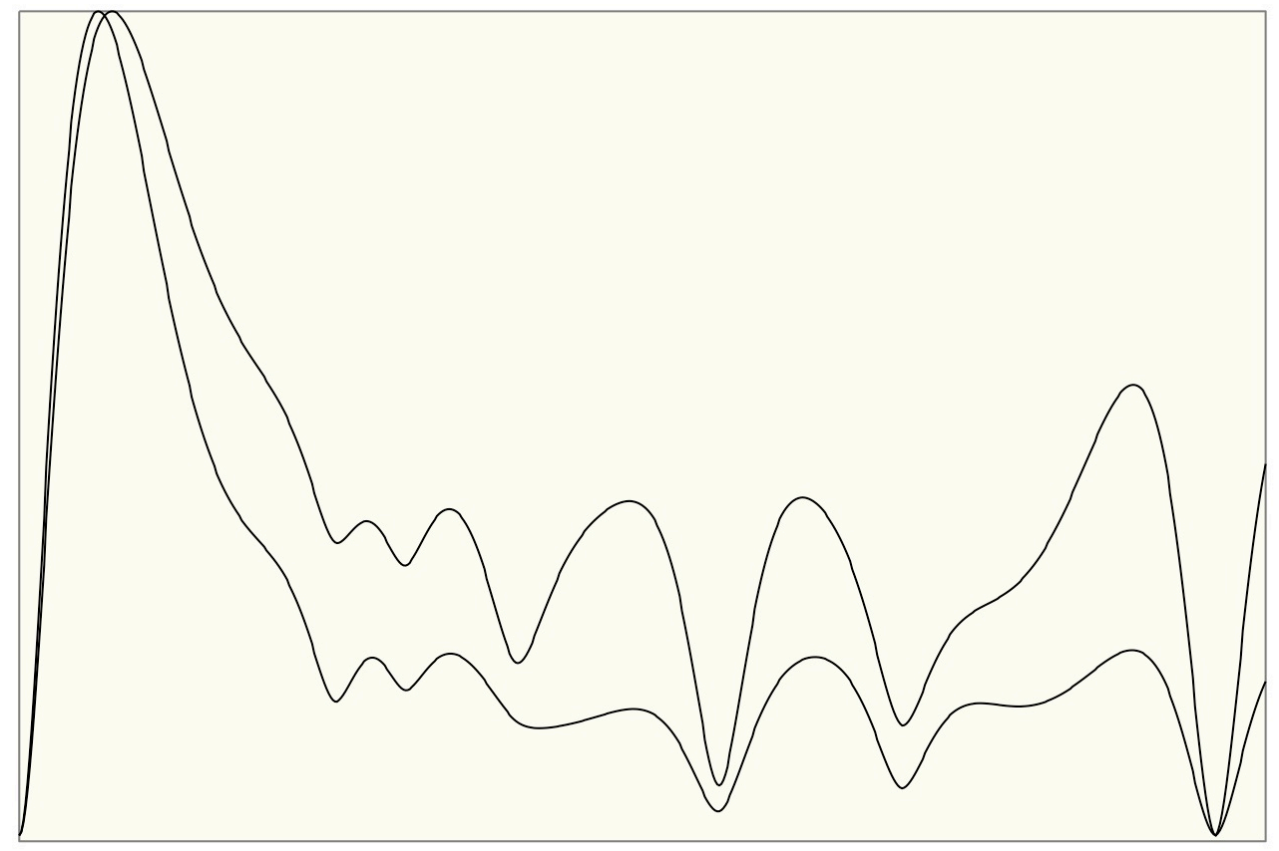

Figura 80 - Barlow com e sem mascaramento.

A respeito do mascaramento, tivemos dificuldade em incluir o processo adotado por Barlow, que se baseia em um modelo de mascaramento de Zwicker e Fastl (1999). O problema decorreu de o programa de Barlow adotar outros métodos próprios de análises FFT. Em todo caso, fizemos testes com o modelo de mascaramento existente no modelo de Comonalidade de Altura. Porém, como este altera bastante os valores de amplitudes, a mudança dos resultados é significativa. Compare na figura 80 o perfil de contorno do modelo de Barlow com e sem o mascaramento. O resultado do mascaramento gera a linha de baixo, pela menor energia dos parciais. 
Portanto, temos diferentes parâmetros que geram resultados díspares, como o método de Barlow e Vassilakis para amplitudes diferentes. O modelo de mascaramento também muda os resultados, e há diferentes modelos de mascaramento a serem adotados, que podem gerar outros resultados. O loudness deve ser contabilizado no processo, porém vimos que não promove muita diferença a troco de um alto custo computacional.

Além dessas questões, o detalhe mais importante diz respeito às discrepâncias e implicações dos resultados de Vassilakis. O texto a seguir trará uma discussão mais aprofundada sobre a relação entre as duas principais dimensões de dissonância propostas.

\subsubsection{Aspereza versus Harmonicidade}

Discutiremos aqui a relação da Aspereza com a Harmonicidade, uma segunda dimensão principal relacionada à percepção de Altura. As medidas de Aspereza nas Curvas remetem ao alinhamento e desalinhamento de parciais que promovem, respectivamente, consonância e dissonância. Já os descritores relacionados com percepção de Altura se baseiam na medida de Peso de Altura Virtual, ou seja, em uma medida de harmonicidade e inarmonicidade do espectro, os quais também promovem, respectivamente, consonância e dissonância.

A maioria dos sons adotados em música são tons complexos harmônicos, com alto Tonalness. Para tais sonoridades, o alinhamento de parciais se dá nas mesmas relações de intervalos justos. Entretanto, quando temos uma variação da Harmonicidade, os parciais não mais se alinham nas mesmas relações de números inteiros pequenos, e o intervalo deixa de ser consonante apenas pelo fato de ser uma relação harmônica forte, já que a Aspereza gerada pelos batimentos em uma banda critica promove grande dissonância.

A aspereza é tida como o mais importante elemento psicoacústico da Dissonância, porque, no caso de espectros inarmônicos, um intervalo musical inarmônico que promova alinhamento de parciais provoca menos sensação de dissonância que um intervalo harmônico com Aspereza. O fato é que, no momento de encontrar um intervalo musical consonante de acordo com um espectro inarmônico, há uma espécie de dicotomia e uma falta de meio termo entre a Harmonicidade e a Aspereza. Isso ocorre porque o intervalo eleito é ou o que promove o alinhamento de parciais, ou o que promove a relação harmônica. 
É baseado nessa prevalência da Aspereza que conseguimos gerar escalas a partir de espectros sonoros, ou o inverso por meio do Mapeamento Espectral, em que conseguimos mudar as relações de uma sonoridade para que fiquem de acordo com uma escala. Se a Aspereza não tivesse esse papel de destaque, essa técnica não poderia ter se desenvolvido desta forma.

Porém, a curva de Aspereza em si pode mesmo ser considerada a única dimensão relevante de uma Curva de Dissonância? Essa é a pergunta mais importante que levantamos durante a revisão teórica desta pesquisa. Antes de tentar clarificá-la, vejamos primeiro algumas considerações sobre a dimensão que aqui definimos por Harmonicidade e problemas envolvendo diferentes modelos de Aspereza.

Segundo o trabalho de Vassilakis (2001), a tendência semelhante dos modelos de Aspereza (que não empregam sua revisão) é imprópria. Todavia, as Curvas de Aspereza de tais modelos possuem perfis de contorno que parecem representar nossa sensação de Dissonância. Considere-se o trítono como exemplo, que, no modelo de Aspereza de Vassilakis, chega a ser mais "consonante" (ou menos rugosa) que a terça maior.

Por mais que a revisão teórica de Vassilakis esteja acurada (no que diz respeito à Aspereza), as Curvas de Aspereza de outros modelos têm gerado resultados satisfatórios em uma prática musical, na qual se pretende emular uma sensação de Dissonância. Uma contribuição importante do trabalho de Vassilakis é separar melhor o conceito de dissonância e Aspereza por meio de testes. Com esse método, o autor investiga a relação de Aspereza com a Dissonância.

Em compensação, seria pertinente uma investigação similar, que se voltasse a outros atributos psicoacústicos, como o Brilho, Tonalness e Comonalidade de Altura. A maior questão se encontra na relação entre Aspereza e a dimensão de Harmonicidade, em que levantamos a questão de se a Harmonicidade não possui um papel mais relevante do que o esperado, e que pode ser considerado na geração de Curvas de Dissonância.

Como já mencionado, a área de psicoacústica e cognição está em constante debate e revisão. Uma vez que não temos um ponto final sobre a relação dessas duas dimensões em Psicoacústica, novos estudos da área de neurociência também têm se dedicado a este problema. Embora nenhum modelo tenha ainda sido proposto, podemos ressaltar as considerações trazidas pela pesquisa de Dermott et. al (2010), que compara a Aspereza com um conceito de harmonicidade. 
O termo "harmonicidade" ao qual o autor se refere não designa um atributo perceptivo específico, como os trazidos e debatidos aqui, apenas diz respeito a estímulos formados por espectros harmônicos. Logo, trata-se de um conceito descritivo acústico, como um conceito e modelo de harmonicidade existente em Descritores de Áudio. Em todo caso, há uma relação com os atributos perceptivos que aqui colocamos dentro de uma dimensão de Dissonância também chamada "Harmonicidade", e entendemos que há uma relação entre nosso conceito de Dimensão de Harmonicidade e a "harmonicidade" a que Dermott se refere.

Os resultados do seu experimento apontam para uma forte correlação entre consonância e harmonicidade para a maioria dos participantes, mais do que a falta de batimentos ou Aspereza. A correlação foi ainda mais forte para os participantes com treinamento musical, sugerindo que uma exposição maior à música amplifica a sensibilidade a espectros harmônicos, dado sua importância em música.

O estudo é recente, e o problema ainda precisa ser melhor investigado. Em uma publicação anterior (2008), o autor também ressalta as dificuldades envolvidas numa investigação dos atributos perceptivos da dissonância. $O$ fato é que diferentes teorias produzem resultados similares, o que é um indício reafirmado em nossa própria pesquisa, em que comparamos resultados de diferentes atributos com resultados similares. Por exemplo, na Figura 63, comparamos Comonalidade de Altura, Aspereza, Tonalness Puro e Complexo, e encontramos alguns padrões em comum. Até mesmo a teoria de Entropia Harmônica de Elrich nos dá um mesmo tipo de contorno gráfico da Aspereza. A dificuldade que surge é a de isolar e verificar cada premissa. Por isso, Dermott et. al (2010) adotou um método de Psicologia das Diferenças Individuais.

Essa abordagem, como se trata de um estudo ainda recente, traz a necessidade de mais desenvolvimentos e indica como a investigação do problema de percepção de dissonância está em pleno desenvolvimento, desde o surgimento da Psicoacústica. Em nossa revisão teórica, encontramos a necessidade de gerar novos testes e investigar melhor a relação entre os atributos perceptivos da Dissonância. Apesar das dificuldades e desafios, com o olhar geral que obtivemos durante a pesquisa, pudemos encontrar vários trabalhos interessantes, mas com boa margem para melhorias, ou adaptações incluindo pontos positivos de outros trabalhos isolados. A seguir, como exemplo, apresentamos um primeiro teste perceptivo, que nos ajudou em alguns aspectos dessa problemática. 


\section{3 - Teste perceptivo de Dissonância sob uma Perspectiva Sensorial}

Este estudo foi inspirado pelo trabalho de Vassilakis (2001). Em parte, adotamos algumas características semelhantes. Após a exposição dos resultados, trazemos algumas implicações e apontamos futuras investigações. Vassilakis (2001) investiga a relação entre Aspereza e Dissonância, mas seu experimento não define com cautela o segundo conceito e como ele se distingue do primeiro (pensado como uma dimensão sensorial da Dissonância). Mesmo sem esses detalhes, o conceito de Dissonância, nesse caso, abre margem para uma interpretação cultural e individual.

Em nosso experimento, apresentamos um conceito de Dissonância Psicoacústica, formada pelos atributos perceptivos estudados e implementados em pesquisa. Também investigamos uma distribuição diferente de intervalos musicais com praticamente apenas intervalos justos, em um conjunto de 25 díades no espaço de uma oitava. Por serem intervalos justos, os passos não são regulares em cents, mas, grosso modo, é como se fossem passos de quartos de tom.

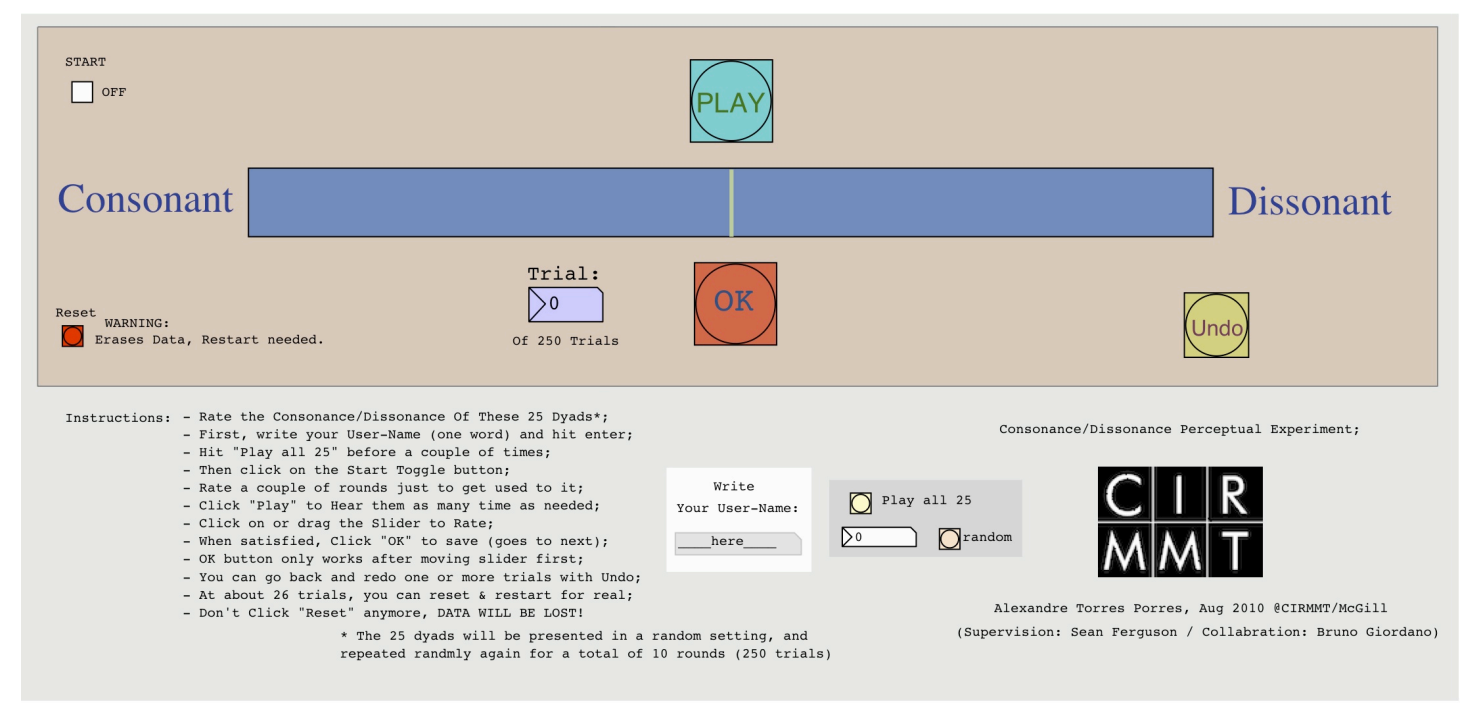

Figura 81 - Interface do Teste Perceptivo.

A interface do teste (vide figura 81 ) foi implementada em um patch de Pure Data. Os participantes pediam para tocar uma díade, marcavam o valor de dissonância em um slider contínuo e seguiam para a próxima estimativa. Caso quisessem, poderiam voltar e refazer uma estimativa, ou tocar quantas vezes quisessem antes de aferir um resultado.

As 25 díades foram dispostas em uma série aleatória. Ao todo, foram dez rodadas. Portanto, cada intervalo foi medido dez vezes, totalizando 250 medidas por 
participante. O experimento contou com 20 participantes com formação musical variada. E foi desenvolvido com a ajuda de Bruno Giordano, pesquisador colaborador na área de Psicologia da Música, sob a supervisão do Prof. Dr. Sean Ferguson, então diretor do centro de pesquisa CIRMMT $^{38}$, em McGill, Montreal, Canadá, onde o experimento foi conduzido em agosto de 2010, durante um estágio de pesquisa.

\subsubsection{Estímulos}

Os intervalos Justos adotados são formados por fatores primos até o número 11. Tais intervalos se encontram no famoso sistema de afinação de Harry Partch (1974). O critério de escolha foi partir dos intervalos justos mais próximos ao sistema temperado, formados pelos menores fatores primos. Temos, assim, as versões com maior harmonicidade dos intervalos cromáticos. Entre esses intervalos adjacentes, adicionamos um intervalo mais próximo de um ponto médio. Além de terem uma maior harmonicidade, esse conjunto de intervalos não é culturalmente familiar. Isto foi importante para que os participantes não focassem a atenção no intervalo, a fim de evitar interpretações decorrentes de um intervalo culturalmente familiar.

O único intervalo irracional adotado foi um três oitavos de tom acima do uníssono e abaixo da oitava (75 cents e 1125 cents). Este intervalo não possuía uma aproximação boa em intervalos justos e costuma ser o mais dissonante nos gráficos de Aspereza. Portanto ele foi escolhido entre um intervalo próximo ao quarto de tom e a versão justa de semitom para ser comparado com eles. $\mathrm{O}$ mesmo vale para a inversão, entre a sétima maior e um quarto de tom abaixo da oitava. Para compensar, não há um intervalo entre o semitom e o tom maior, ou entre a sétima menor e a sétima maior. Isso explica-se por não haver interesse na comparação desse intervalo, como ficará mais claro na descrição dos resultados.

Os 25 intervalos escolhidos se encontram na Tabela 12, em uma ordem crescente do uníssono à oitava. Os intervalos são dados em cents, em frações e seu nome de acordo com o sistema de Partch (1974) - salvo o caso dos intervalos baseados em três oitavos de tom, tido apenas como "irracional". O registro foi o mesmo de Vassilakis (de C4 $261.6 \mathrm{~Hz}$ a C5, uma oitava acima). Os 13 intervalos cromáticos foram apresentados em versões de Afinação Justa, são eles: Uníssono (1/1), semitom $(16 / 15)$, tom $(9 / 8)$, terça menor $(6 / 5)$, terça maior $(5 / 4)$, quarta $(4 / 3)$, trítono $(7 / 5)$,

$38 \quad$ Sítio da internet: $<$ http://www.cirmmt.mcgill.ca/ $>$. 
quinta (3/2), sexta menor (8/5), sexta maior (5/4), sétima menor (7/4), sétima maior $(15 / 8)$ e oitava $(2 / 1)$.

Tabela 12. Intervalos adotados no teste.

\begin{tabular}{|c|c|c|c|}
\hline 01) & Uníssono & $(1 / 1)$ & 0 cents \\
\hline 02$)$ & $+1 / 4$ de Tom & $(33 / 32)$ & 53.2 cents \\
\hline 03) & $+3 / 8$ Tom & irracional & 75 cents \\
\hline 04) & Semitom & $(16 / 15)$ & 111.7 cents \\
\hline 05$)$ & Tom & $(9 / 8)$ & 203.9 cents \\
\hline 06) & $3^{\mathrm{a}} \mathrm{m}$ Septimal & $(7 / 6)$ & 266.9 cents \\
\hline 07) & $3^{\mathrm{a}} \mathrm{m}$ & $(6 / 5)$ & 315.6 cents \\
\hline 08) & $3^{\mathrm{a}}$ Neutra & $(11 / 9)$ & 347.4 cents \\
\hline 09) & $3^{\mathrm{a}} \mathrm{M}$ & $(5 / 4)$ & 386.3 cents \\
\hline 10) & $3^{\mathrm{a}} \mathrm{M}$ Septimal & $(9 / 7)$ & 435.1 cents \\
\hline 11) & Quarta & $(4 / 3)$ & 498 cents \\
\hline 12) & Quarta Aumentada & $(11 / 8)$ & 551.3 cents \\
\hline 13) & Trítono Septimal & $(7 / 5)$ & 582.5 cents \\
\hline 14) & Quinta Diminuta & $(16 / 11)$ & 649 cents \\
\hline 15) & Quinta & $(3 / 2)$ & 702 cents \\
\hline 16) & $6^{\mathrm{a}} \mathrm{m}$ Septimal & $(14 / 9)$ & 764.9 cents \\
\hline 17) & $6^{\mathrm{a}} \mathrm{m}$ & $(8 / 5)$ & 813.7 cents \\
\hline 18) & $6^{a}$ Neutra & $(18 / 11)$ & 852.6 cents \\
\hline 19) & $6^{\mathrm{a}} \mathrm{M}$ & $(5 / 3)$ & 884.4 cents \\
\hline 20) & $6^{\text {a }}$ Septimal & $(12 / 7)$ & 933.1 cents \\
\hline 21) & $7^{\mathrm{a}}$ Harmônica & $(7 / 4)$ & 968.8 cents \\
\hline 22) & $7^{\mathrm{a}}$ Maior & $(15 / 8)$ & 1088.3 cents \\
\hline 23) & - 3/8 de Tom & irracional & 1125 cents \\
\hline 24) & - $1 / 4$ de Tom & $(54 / 33)$ & 1146.8 cents \\
\hline 25$)$ & Oitava & $(2 / 1)$ & 1200 cents \\
\hline
\end{tabular}

Dentre esses, o trítono (7/5) e a sétima menor (7/4) foram os intervalos com o maior fator primo (número 7). Dos demais, temos os usuais intervalos até o fator primo 5. Esses intervalos são bem próximos aos temperados e, portanto, são percebidos como o mesmo intervalo, porém mais consonantes.

A maior percepção de consonância se dá não só pelo maior alinhamento dos parciais (menor Aspereza), mas também pela Harmonicidade (já que estão no sistema de Afinação Justa). Mas, para que esses intervalos despontassem como mais consonantes em sua área vizinha (uma hipótese previamente desenvolvida), os outros intervalos foram inseridos entre esses intervalos cromáticos, formados pelos fatores primos 7 e 11 .

As díades foram formadas por amostras reais de oboé, extraídas da biblioteca Vienna Symphonic Library ${ }^{39}$. Com o programa Melodyne ${ }^{40}$, tratamos as gravações

\footnotetext{
39 Disponível em; $<$ http://vsl.co.at/ $>$.

40 Disponível em; $<$ http://www.celemony.com/cms/>.
} 
para remover vibrato e aplicar uma pequena mudança de altura para que ficassem de acordo com os passos dados pelos intervalos adotados. Escolhemos as amostras de dinâmica média, e as durações de cada díade foram editadas em dois segundos.

O experimento foi calibrado para que o estímulo fosse tocado a um nível de 60 dB-SPL. O equipamento adotado foi uma placa de som Apogee Duet, um fone de ouvido Seinheiser HD-518 e um Macbook Pro com processador i7 rodando o patch de Pure Data.

O som de oboé foi escolhido por possuir uma boa riqueza espectral, com uma relativamente grande energia e Brilho. Essa característica sonora colabora para uma dimensão de Aspereza. Mas, em todo caso, a intenção não era isolar ou fazer prevalecer essa dimensão, mas, apesar dela, encontrar uma medida geral de Dissonância. Alguns participantes mencionaram que, em momentos, os estímulos soavam como buzinas de carro, e outros disseram que não se deram conta que não eram tons sintetizados.

\subsubsection{Teste e Resultados}

Antes do teste em si, uma fase de treinamento visava explicar o objetivo do teste. Nessa conversa, os participantes expunham seus conceitos e ideias de Dissonância, quando se avaliava se possuíam a noção de um enfoque sensorial desta grandeza, na medida em que ela estaria relacionada a alguns atributos psicoacústicos. Nenhum participante demonstrou estranheza ao conceito. Em diferentes graus, alguns puderam expor uma noção relativamente clara de conceitos como a Aspereza e Harmonicidade.

Após essa primeira conversa, alguns exemplos foram dados para verificar o entendimento dos participantes. Usamos o exemplo da oitava dissonante de Sethares (1999). Todos os participantes não tiveram dificuldade em indicar que o som da oitava é mais dissonante, conforme a intenção didática de Sethares. Em compensação, apesar de mais consonante, os participantes eram capazes de relatar uma qualidade inarmônica na sonoridade de Nona Maior. Em comparação a esses exemplos, tocamos também o som de oboé, harmônico em relação de oitava. Não houve divergência também em constatar-se que esta seria a sonoridade mais consonante dentre as três.

Assim, apresentamos estes conceitos mais importantes da Dissonância sob um enfoque Psicoacústico: a Aspereza e Harmonicidade (que entendemos se relacionar com Tonalness e Comonalidade de Altura). Apontamos que não é claro como esses 
fatores se relacionam e que parte do estudo visava encontrar um maior entendimento desse problema. Afirmamos também que havia mais detalhes e outros elementos psicoacústicos em jogo.

Em todo caso, não adentramos em detalhes conceituais sobre conceito de Brilho, Tonalness e Comonalidade de Altura. A intenção era apenas firmar uma ideia de que existem atributos psicoacústicos relacionados à percepção de dissonância, apresentar esses dois conceitos mais relevantes e depois pedir para que os participantes tentassem buscar uma escuta mais concreta para propriedades sonoras do que abstrações teórico-musicais, sem focar a percepção em uma dimensão específica, mas em uma sensação geral do estímulo.

No começo do teste, duas rodadas experimentais foram feitas para que o participante se acostumasse com o processo e sistema. Após mais uma breve conversa sobre possíveis dúvidas, seguimos com o teste em si. Ao todo, desde a primeira conversa até o fim do teste, uma média de 45 minutos bastou para finalizar o processo. Os resultados foram guardados em arquivos de texto, junto com o tempo do teste, quantas vezes e quando algum intervalo precisou ser repetido e todas as séries aleatórias geradas.

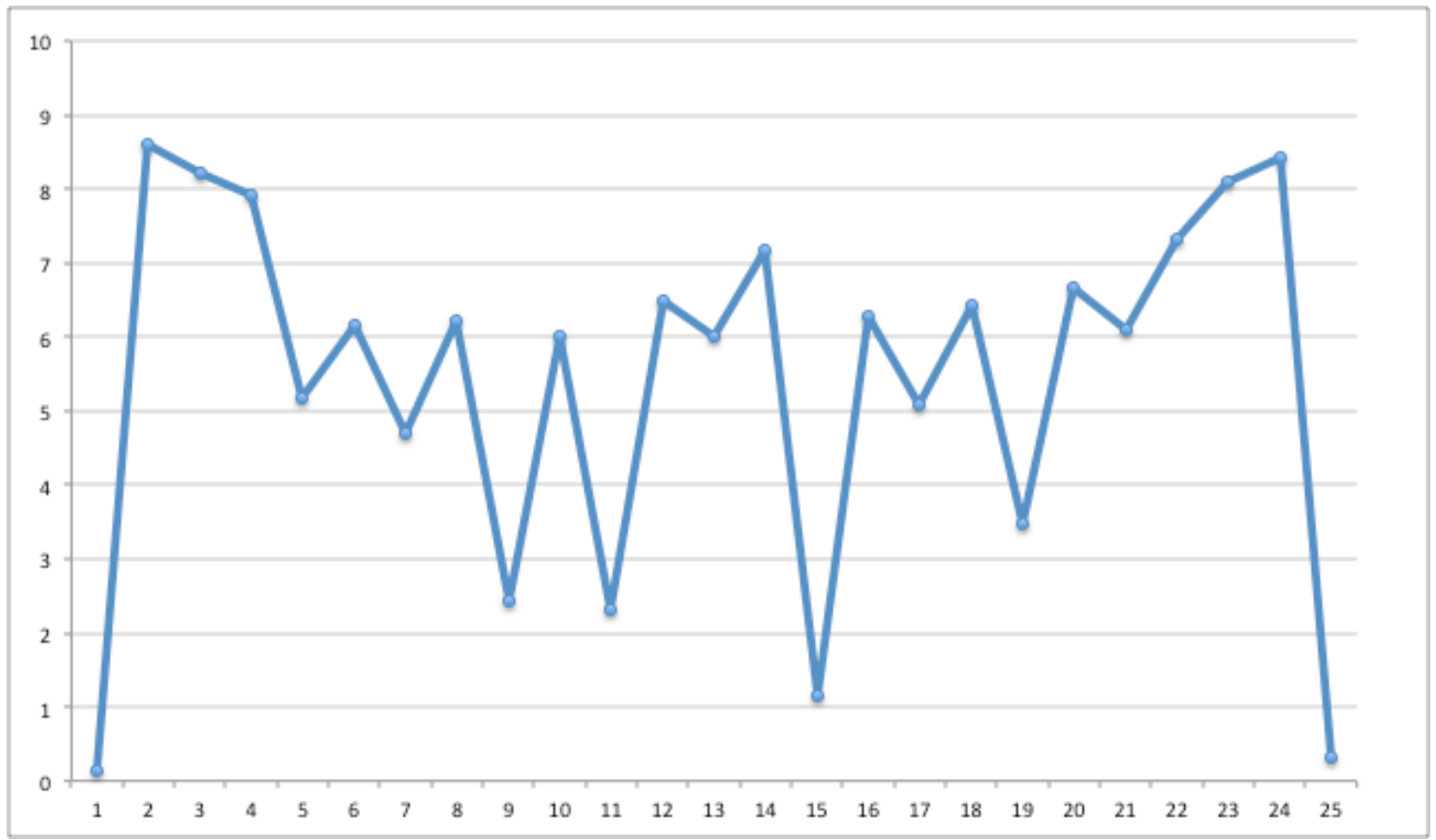

Figura 82 - Média dos níveis de dissonância encontrados por meio dos julgamentos dos participantes $(n=20)$.

Os valores contínuos variavam entre 0 (extremo da consonância) e 10 (extremo 
da dissonância). O valor do slider, para cada nova medida, retornava ao centro (valor igual a 5). Assim, dividimos em pelo menos dois grupos categóricos de percepção, valores mais dissonantes (acima de 5) e mais consonantes (abaixo de 5). Vejamos a média dos resultados na figura 82 e tabela 13 (dados completos em anexo).

Tabela 13. Médias e desvios-padrão

\begin{tabular}{|c|c|c|c|c|c|}
\hline \multicolumn{2}{|c|}{$\begin{array}{l}\text { Intervalos } \\
\text { em cents }\end{array}$} & $\begin{array}{l}\text { Médias de } \\
\text { Dissonância }\end{array}$ & $\begin{array}{l}\text { Desvio } \\
\text { Padrão }\end{array}$ & \multicolumn{2}{|c|}{$\begin{array}{l}\text { Médias de Dissonância } \\
\text { em ordem crescente }\end{array}$} \\
\hline 01) & 0 & 0.14 & 0.22 & 0 cents $(1)$ & 0.14 \\
\hline 02) & 53 & 8.59 & 1.82 & 1200 cents $(25)$ & 0.31 \\
\hline 03) & 75 & 8.21 & 1.86 & 702 cents $(15)$ & 1.15 \\
\hline 04) & 112 & 7.93 & 1.64 & 498 cents $(11)$ & 2.32 \\
\hline 05$)$ & 204 & 5.17 & 1.73 & 386 cents (9) & 2.43 \\
\hline 06) & 267 & 6.17 & 1.64 & 884 cents (19) & 3.47 \\
\hline 07) & 316 & 4.69 & 1.68 & 316 cents (7) & 4.69 \\
\hline 08) & 347 & 6.21 & 1.34 & 814 cents (17) & 5.07 \\
\hline 09) & 386 & 2.43 & 1.32 & 204 cents (5) & 5.17 \\
\hline 10) & 435 & 6.00 & 1.37 & 435 cents $(10)$ & 6.00 \\
\hline 11) & 498 & 2.32 & 0.98 & 582 cents (13) & 6.00 \\
\hline 12) & 551 & 6.49 & 1.15 & 969 cents $(21)$ & 6.09 \\
\hline 13) & 582 & 6.00 & 1.29 & 267 cents (6) & 6.17 \\
\hline 14) & 649 & 7.17 & 1.08 & 347 cents $(8)$ & 6.21 \\
\hline 15) & 702 & 1.15 & 0.58 & 765 cents $(16)$ & 6.28 \\
\hline 16) & 765 & 6.28 & 1.27 & 853 cents $(18)$ & 6.43 \\
\hline 17) & 814 & 5.07 & 1.52 & 551 cents (12) & 6.49 \\
\hline 18) & 853 & 6.43 & 1.07 & 933 cents $(20)$ & 6.66 \\
\hline 19) & 884 & 3.47 & 1.31 & 649 cents $(14)$ & 7.17 \\
\hline 20) & 933 & 6.66 & 1.29 & 1088 cents $(22)$ & 7.32 \\
\hline 21) & 967 & 6.09 & 1.29 & 112 cents (4) & 7.93 \\
\hline 22) & 1088 & 7.32 & 1.91 & 1125 cents $(23)$ & 8.09 \\
\hline 23) & 1125 & 8.09 & 1.67 & 75 cents (3) & 8.21 \\
\hline 24) & 1147 & 8.43 & 1.07 & 1147 cents $(24)$ & 8.43 \\
\hline 25) & 1200 & 0.31 & 0.38 & 53 cents $(2)$ & 8.59 \\
\hline
\end{tabular}

O primeiro resultado esperado, por intuição e também influência de modelos de Aspereza, foi um padrão de alternância entre pontos máximos e mínimos por boa parte do registro - o que ocorre entre os intervalos 4 e 22. Desse modo, nessa porção, os intervalos ímpares se apresentam como os mais consonantes, e os pares, como pontos médios entre eles. Nos extremos (díades 1 a 4 e 22 a 25), esse perfil de alternância não era esperado, e sim esse contorno de um maior pico de dissonância, por isso não nos preocupamos em inserir um intervalo de quarto de tom entre o semitom e o tom, assim como a sétima menor e a sétima maior.

Essa esperada tendência de alternância de pontos de maior dissonância e maior consonância é mais clara em alguns casos, como entre a terça maior (díade 09- 386 
cents) e a quarta (díade 11- 498 cents). Porém, não foi apontada uma mesma tendência entre as inversões desses intervalos, a quinta (díade 15- 702 cents) e a sexta menor (díade 17- 814 cents). O menor desvio padrão para consonâncias como o uníssono, oitava, quinta e quarta (em negrito na tabela 13) denota uma maior certeza das medidas para esses casos.

Entre outros intervalos, não havia certeza antes do teste se, de fato, haveria a acusação de uma alternância. O ponto de maior dúvida era em torno da região do trítono. Todavia, de fato, o intervalo de trítono formado pela fração [7/5] (díade 13582 cents) foi tido como mais consonante que suas versões vizinhas, a fração [11/8] (díade 12- 551 cents) e [16/11] (díade 14- 649 cents).

Levantamos a hipótese que a existência de mais batimentos e a proximidade com uma forte consonância (como a quarta e quinta) aumentam a percepção de dissonância. Além de Batimentos em si, podemos considerar a dimensão de Harmonicidade, ou melhor, de Inarmonicidade. Pois, no caso, percebe-se que há uma proximidade com um padrão harmônico, mas que se encontra de um modo Inarmônico, ou difuso e incompleto.

Nos modelos de Aspereza, entretanto, o intervalo em torno de 3/8 de tom acima (01- 75 cents) e abaixo (24- 1125 cents) costuma aparecer como mais dissonante em relação a quartos de tom. Mas os resultados obtidos no teste sugerem o contrário, que a percepção de Batimentos dos quartos de tom é percebido como mais dissonante que o ponto de maior Aspereza. Talvez em parte pela escolha de outro tipo de estímulo, que contém mais energia que o estudo de Vassilakis (vide Figura 75, em vermelho), a tendência do nosso gráfico vai contra a ideia que o Pico de Dissonância em torno da oitava é significativamente menor que o do em torno do uníssono.

Outra tendência dos modelos de Aspereza é que o pico de dissonância em torno do uníssono é maior que o presente em torno da oitava. Os resultados do teste indicam picos similares. Ressaltamos, porém, a grande discrepância que há no modelo de Vassilakis, que possui uma tendência de decaimento e um pico bem menores em torno da oitava.

$\mathrm{Na}$ figura 83, temos duas curvas que comparam os resultados do modelo de Barlow (sem loudness e mascaramento) com o de Vassilakis. Pode ser argumentado que o método de Vassilakis é mais acurado na medida de Aspereza, mas o método de Barlow é capaz de gerar um perfil mais próximo ao que se espera de uma curva de dissonância, promovendo maiores contrastes. 


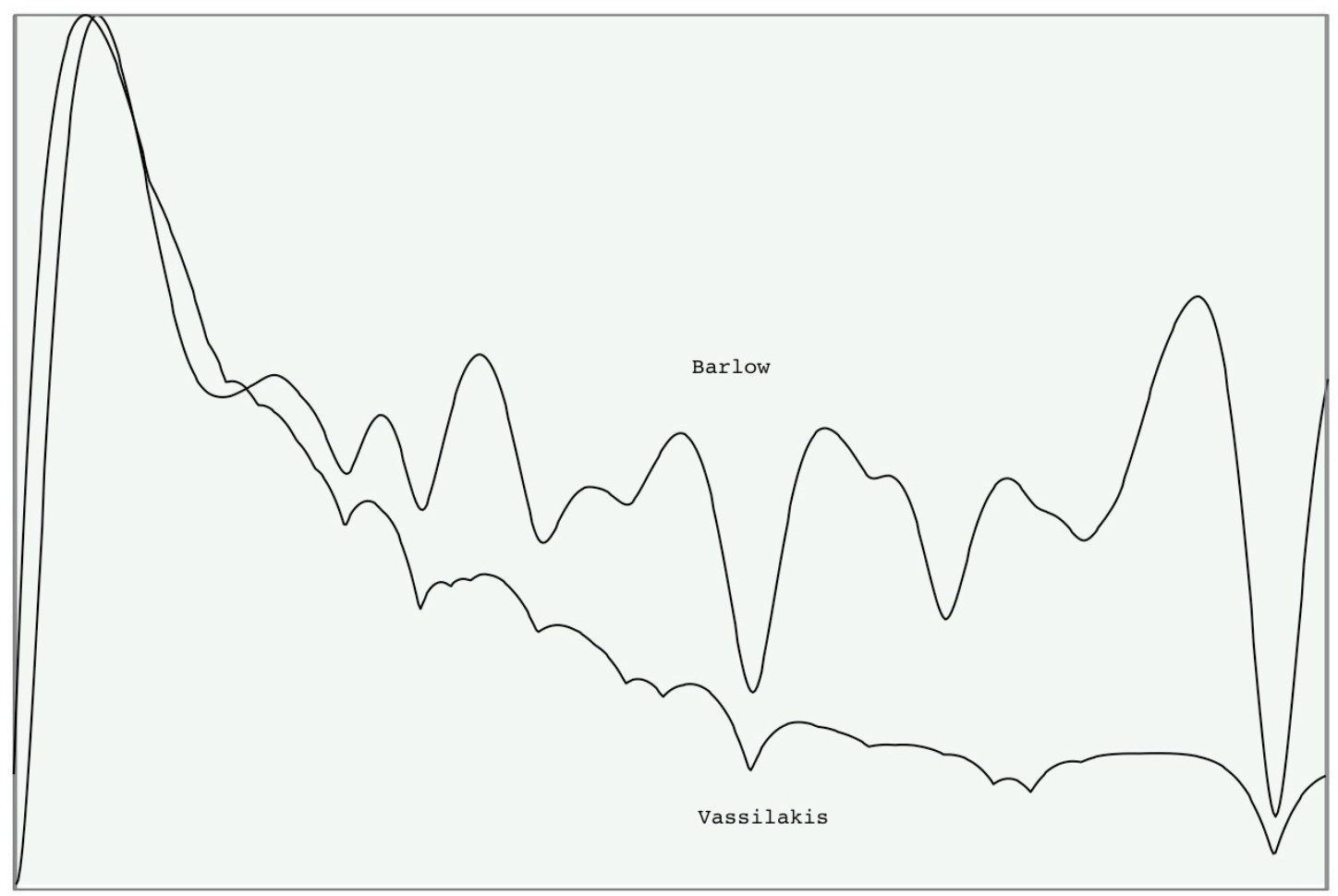

Figura 83 - Curvas de modelos de Aspereza para o estímulo e registro do teste.

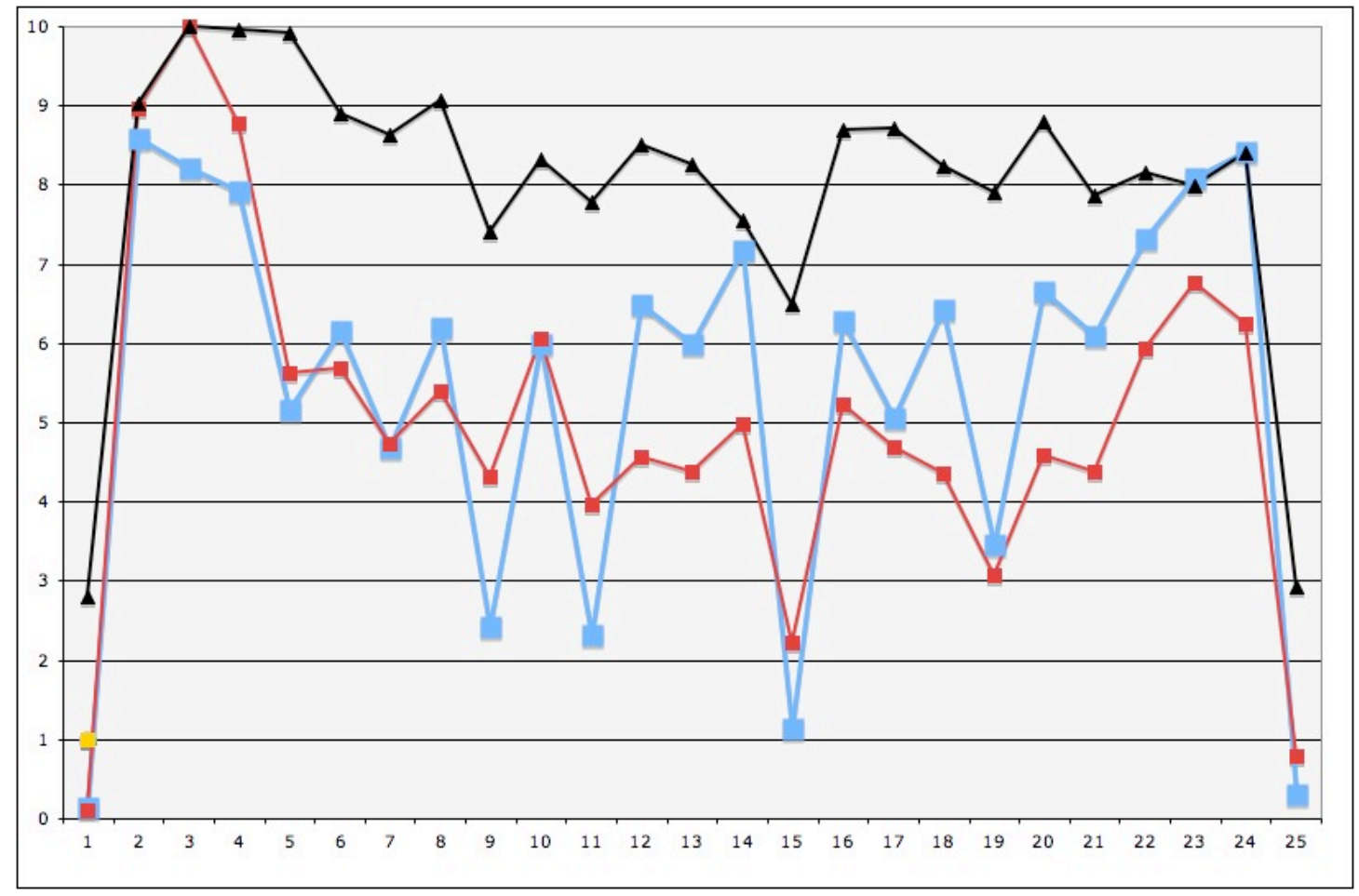

Figura 84 - Aspereza (vermelho), resultados do teste (azul) e Tonalness (preto).

Vejamos agora a figura 84 que traz os resultados de Aspereza do método de Barlow (apenas para as 25 díades adotadas no teste) mais o resultado do modelo de 
Tonalness em comparação aos resultados do teste. Há mais semelhanças entre os resultados com as medidas de Aspereza do que com as de Tonalness, como em um padrão mais similar de alternância e contrastes entre pontos máximos e mínimos. As medidas de Tonalness ainda apontam um padrão moderadamente similar aos resultados, porém com menos alternância e contrastes entre pontos máximos e mínimos. O gráfico de Tonalness representa a harmonicidade e seu resultado gerou mais contrastes para comparação que a Comonalidade de Altura.

Um dos pontos de maior divergência entre os resultados do teste e do modelo Aspereza já foi apontado, que é o fato de os intervalos de quarto de tom (díades 2 e 24) terem sido aferidas com mais dissonância que os de 3/8 de tom (díades 3 e 23). Esses costumam ser os mais dissonantes, por estarem mais próximos ao intervalo máximo de Aspereza (um quarto da Banda Crítica), como o contorno da Aspereza em vermelho na figura 84 confirma.

Outra divergência se encontra na díade 17 , a sexta menor $(8 / 5)$ - ou ainda 814 cents. Diferente do resultado do teste, esse intervalo não foi acusado pelo modelo de Aspereza como um ponto mínimo de consonância. A hipótese é que esse intervalo se encontra na proximidade da quinta justa, um dos intervalos de maior alinhamento. Logo, ainda ocorre um desalinhamento de parciais na sexta menor, que impede seu aferimento como consonância.

Já o Tonalness, por ser um conceito distinto da Aspereza, não necessariamente acusa picos ao lado de fortes consonâncias, como a díade 14 logo abaixo da quinta justa. Fato é que uma maior resolução de intervalos no Tonalness torna o seu gráfíco mais parecido com uma medida de Harmonicidade como aferida pelo conceito de Barlow (vide figura 45).

A Comonalidade de Altura possui uma característica similar. De modo que não nos ficou claro como esses diferentes fatores podem ser combinados em uma medida conjunta de Curva de Dissonância.

\section{4 - Considerações Finais}

Um dos maiores problemas apresentados está nas controvérsias dos possíveis modelos de Aspereza. O estudo de Plomp e Levelt (1965) é antigo, e mesmo Vassilakis aponta para possíveis revisões em que podemos medir, atualmente, esse importante atributo auditivo com uma melhor definição de linguagem em um conceito mais refinado. Ressaltamos como diversos outros testes também devem ser feitos 
como refinamento.

Um dado interessante que encontramos foi o resultado de intervalos de quarto de tom terem sido medidos como mais dissonantes do que os intervalos de maior Aspereza dados por modelos. A conclusão é que, por mais que haja menos Aspereza, uma maior sensação de Batimentos promove uma forte sensação de desafinação, que é percebida como mais Dissonante. Sugerimos uma revisão da Curva de Plomp e Levelt (1965), onde um contínuo engloba a sensação de Batimentos e Aspereza em um mesmo contorno e tendência de curva, que aponta um quarto da banda crítica como a sensação máxima dessa dimensão conjunta de Aspereza que engloba os batimentos.

Ainda em relação à Aspereza, não está claro como ela deve ser contabilizada a partir de amplitudes desiguais. Apenas o modelo de Barlow buscou adotar os contornos de loudness e mascaramento, mas sem uma devida validação por meio de testes psicoacústicos. Portanto não sabemos se, com isso, os dados realmente ganham qualidade ou quanto.

A revisão e modelo de Vassilakis trazem implicações sérias sobre a relação entre medidas de Aspereza e Dissonância. Seus testes perceptivos são dos poucos que focam somente em Aspereza e comparam essas medidas com as dissonância. A tendência de seus gráficos é descendente, e há um menor contraste entre pontos máximos e mínimos.

Em nosso teste perceptivo, constatamos como esses dados pouco nos ajudam na relação com uma medida de Dissonância. Nesse sentido, seria bom refazer um teste com um mesmo estímulo do que o usado por Vassilakis, para compararmos com seus resultados.

Em comparação ao teste de Vassilakis (2001), além da Aspereza, consideramos também a Harmonicidade, compreendida principalmente pelo Tonalness e Comonalidade de Altura sem porém estar claro como unir esses dois conceitos em uma medida única. Em relação aos estímulos, adotamos uma fonte sonora de maior riqueza e energia espectral e incluímos mais pontos (ou intervalos) como maneira de aumentar a resolução dos dados. Uma tendência esperada de alternância entre pontos máximos e mínimos foi encontrada. Um passo seguinte pode incluir uma resolução ainda maior, com o dobro de intervalos, por exemplo, para compararmos os resultados e investigar como se dá uma maior nuance de alternância entre esses intervalos.

Um objetivo ideal poderia ser uma divisão microtonal que possa gerar uma boa continuidade, algo como uma divisão da oitava em 72 partes que, como apontado por 
Navarro (1927), possui uma boa aproximação dos intervalos justos que adotam até o fator primo 11 - como o sistema de Partch e seus 43 intervalos por oitava. Seria possível, então, incluir todos os intervalos de Partch (que também fazem parte de nosso teste) e ainda outros. No final das contas, teríamos uma curva de boa continuidade também passível de comparação com o One Footed Brigde de Partch (1974), trazida na figura 87, no próximo capítulo.

A adoção de diferentes estímulos deve contemplar também sonoridades inarmônicas, para que possamos melhor investigar a dimensão de Harmonicidade em comparação com os resultados de testes com estímulos harmônicos.

Testes de dissonância que, na fase de treinamento não focam em uma abordagem sensorial, podem também ser produzidos para verificar se há uma diferença com os dados produzidos com esse tipo de enfoque. Tais resultados devem trazer mais validação ao estudo.

São poucos os estudos que visam investigar melhor a relação entre as duas dimensões principais de Dissonância (Aspereza e Harmonicidade), já que se trata de um processo problemático. Dermott et. al (2010) geraram resultados novos importantes que devem ser trazidos à discussão, em que um papel relevante da harmonicidade foi considerado. Porém, a relação entre essas duas dimensões de Dissonância (análogas à proposta nesta pesquisa) ainda não está clara, dependendo de mais estudos nessa direção.

Encontramos uma boa relação entre os resultados do teste e um método de Barlow (2008), que contabiliza a Aspereza de modo arbitrário. Na prática, mede-se apenas o alinhamento e desalinhamento de parciais e, nesse ponto, pouco importa uma aproximação acurada dos dados de Plomp e Levelt, a maior diferença se dá na inclusão do método de Vassilakis (2001). Nesse ponto, abre-se margem para conceitos e modelos mais arbitrários, como o modelo de Aspereza de Barlow ou ainda seu conceito de Harmonicidade (Barlow 1980) e a Entropia Harmônica de Elrich (1997) que poderiam ajudar a emular os resultados de dissonância.

Em suma, na verdade, sabemos ainda muito pouco sobre os modelos psicoacústicos e sua contribuição para descritores de Dissonância em intervalos musicais. A revisão crítica pede diversos refinamentos e traz alguns problemas que ainda serão discutidos no próximo capítulo dentro do objetivo de pesquisa, que é a aplicação criativa em Eletrônica ao Vivo, para composição e improvisação. 


\section{Capítulo 14) Discussão Final Sobre Aplicações Criativas}

Começamos o capítulo com a exposição de dois trabalhos criativos desenvolvidos durante a pesquisa. Na sequência, uma discussão geral sobre o impacto da Psicoacústica em composição e teoria musical. Por fim, uma exposição de um tipo de abordagem composicional que se beneficia da teoria exposta.

\section{1 - Exemplos Criativos}

Trazemos dois exemplos bem distintos de aplicação do sistema [Brane ] e algumas considerações sobre seu uso e potencial. A primeira abordagem trata de um duo de improvisação livre, em que todas as funcionalidades do sistema foram colocadas à prova. Já a segunda abordagem é uma peça orquestral para solistas e eletrônica ao vivo, em que uma aplicação bem específica do sistema foi adotada, como um adendo à parte orquestral, sendo um elemento textural a mais na peça.

\subsubsection{Duo de Improvisação Livre com Rogério Costa}

O sistema [Brane ] foi testado em performance em vários ensaios e algumas apresentações a partir de um duo formado pelo autor e pelo pesquisador em improvisação e colaborador Rogério Costa. Rogério tem experimentado com uma primeira versão do Phase Vocoder, apresentado na Figura 73, e não tem trabalhado com os conceitos e ferramentas próprios desta pesquisa. No duo, ele toca Saxofone Alto com esse seu sistema usual.

Já este autor recebe o mesmo sinal acústico do Sax e controla diversas manipulações paralelas com o sistema [Brane $]$. Concomitantemente, o autor também controla uma instância independente, com uma entrada de áudio de sua execução ao violão.

Enquanto a abordagem a seguir busca um fim específico e quase didático, o uso do sistema em um formato de improvisação foi adotado de uma forma contrastante, em momentos, mais caótica. Não houve a preocupação de explorar recursos distintos de modo claro, mas sim um jogo improvisativo em que diferentes elementos poderiam convergir em um mesmo plano principal, com grandes influências de ideias e a experiência de Rogério Costa (2009).

Porém, para algumas sessões de improvisação, algumas diretrizes foram 
combinadas, como um trecho de notas mais longas e lentas, para que o sistema pudesse aplicar o mapeamento espectral e uma harmonização e reafinação em diferentes escalas. Em trechos do gênero, ambos os instrumentos são manipulados em sistemas inusitados e, ao mesmo tempo, como um mapeamento espectral em divisão igual da oitava em 11 partes e 13 partes. Essa estrutura, por exemplo, pode ir se transformando aos poucos para uma seção mais pontilhista, em que processos de manipulação de distorção espectral ocorreriam de modo mais instável, buscando uma imitação gestual entre ambos os intérpretes.

Essa abordagem tem sido a forma principal de prova laboratorial do sistema desenvolvido, em que foram exploradas todas as suas diversas funcionalidades. Essas podem servir a um ambiente de eletrônica ao vivo para fins mais estáveis e particulares, menos caóticos. O exemplo a seguir é o de uma peça orquestral, em que o sistema adotou um processo específico para os solistas.

\subsection{2 (i)re(v||f)erência, de Alexandre Torres Porres (2011)}

A peça foi composta em 2011, comissionada para o concerto de fechamento da $\mathrm{I}^{\mathrm{a}}$ Bienal Música Hoje, em Curitiba, pelo grupo Ensemble EntreCompositores ${ }^{41}$ (formado por compositores curitibanos), com a execução da orquestra da UFPR e solistas do grupo austríaco Platypus. As duas partes solistas da peça são para flauta/piccolo e clarinete em $\mathrm{Bb} /$ clarone.

A peça possui um tema principal, que aparece em diversas variações e arranjos no decorrer da obra. A duração é de cerca de 11 minutos e há vários contrastes de mudanças relativamente bruscas. Porém, o tema principal é um elemento unificador, que é recorrente em diferentes variações, nas quais o uso de eletrônica ao vivo serviu para adicionar mais uma coloração e variação instrumental/timbrística ao conjunto e aparece apenas em três trechos.

A função da eletrônica ao vivo na peça é de orquestração e acompanhamento, em um plano de fundo e seu processamento foi aplicado nas partes solistas, mais especificamente na flauta e no clarinete. Duas instâncias independentes do sistema [Brane $]$ foram adotadas, uma para cada parte solista.

\footnotetext{
41 O concerto contou com seis peças compostas pelos compositores, em homenagem póstuma a um de seus membros fundadores - Franco Bueno.
} 


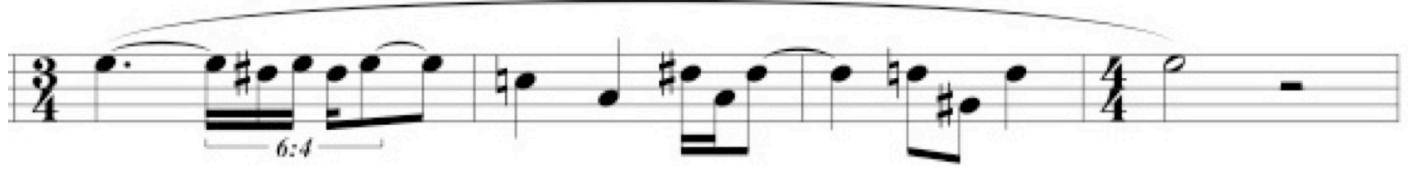

Figura 85 - Primeira exposição do Tema, Clarinete em Bb.

A função da eletrônica ao vivo foi o de orquestração e acompanhamento, em um plano de fundo e seu processamento foi aplicado nas partes solistas, mais especificamente na flauta e no clarinete. Duas instâncias independentes do sistema [Brane $]$ foram adotadas, uma para cada parte solista.

$\mathrm{O}$ intervalo de trítono possui um papel motívico que permeia toda a composição musical. Seu emprego não visava uma resolução tonal ou tensão. A intenção foi de diluir essa tensão de dissonância em motivos melódicos e constante exposição do tema principal, que contém saltos melódicos de trítonos em uma relação de meio tom (vide figura 85 , na parte do clarinete, em uma primeira exposição desse tema).
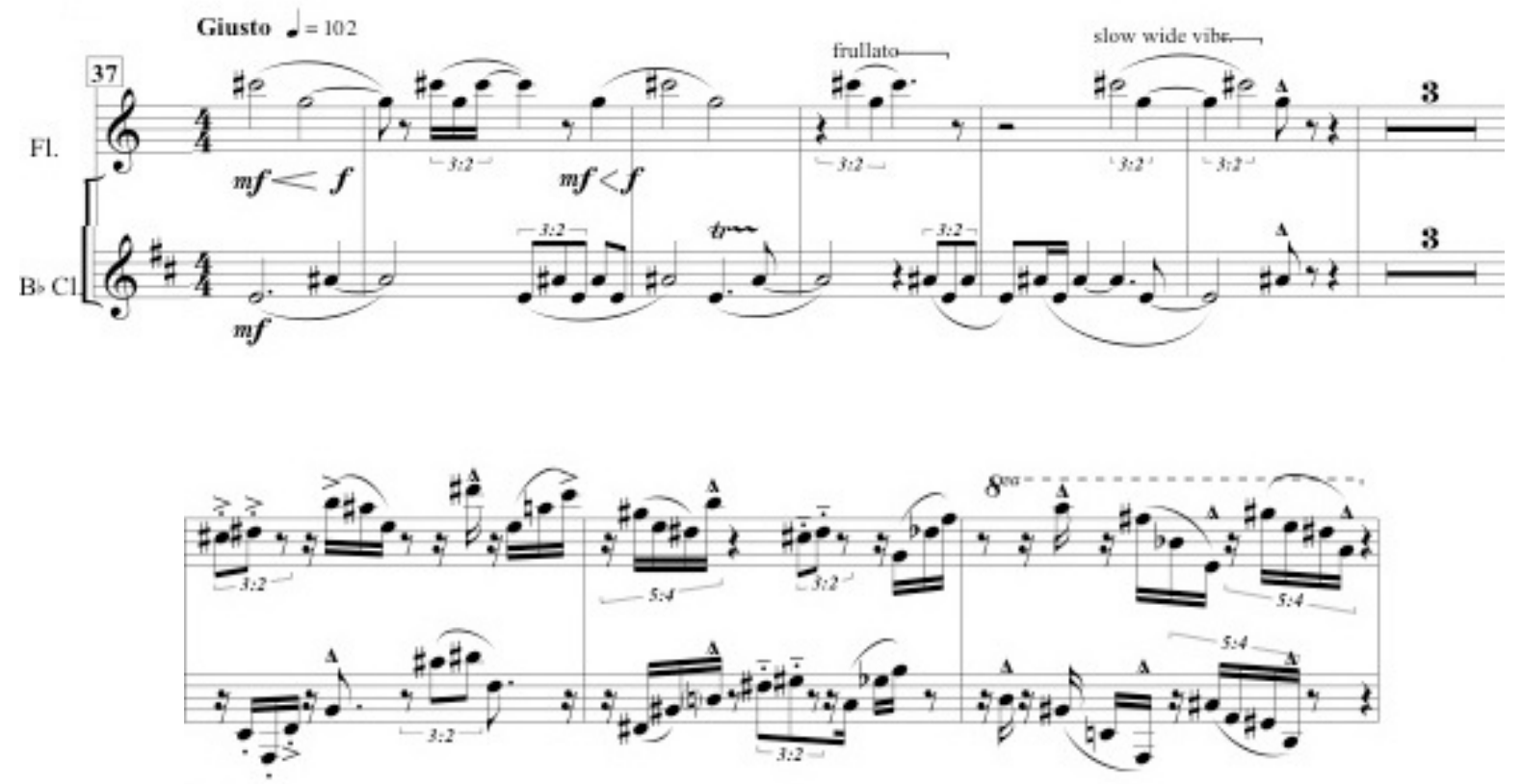

Figura 86 - Primeiro trecho de eletrônica ao vivo.

A figura 86 traz a parte em que o sistema coleta o áudio ao vivo e já inicia o processamento de Mapeamento Espectral e sua execução de fundo pela primeira vez. Estamos ainda em um trecho inicial da peça. A entrada do mapeamento é uma divisão da oitava em quatro partes iguais, ou seja, um acorde diminuto, como um dos exemplos dados na seção deste texto sobre Mapeamento Espectral. 
Temos um contraponto entre dois motivos melódicos distintos, baseados em saltos de trítonos nessa seção. Ambas instâncias do [Brane ] tocam o buffer em uma velocidade de um quarto da original. O mapeamento é o mesmo para ambos, em que uma mesma harmonização se dá em um intervalo de trítonos. Porém, a parte da flauta é transposta uma oitava abaixo, enquanto o clarinete é transposto um trítono acima.

Nos três compassos de pausa da figura 86, somente o processamento de eletrônica ao vivo permanece de fundo. Os solistas ressurgem em seguida com motivos pontilhistas e, além do Mapeamento Espectral de fundo, um simples processamento com o Phase Vocoder é feito em tempo real de modo improvisativo, trazendo para a performance alguns aspectos da experiência em improvisação.

Com a intenção de reforçar a sonoridade de trítonos, o Mapeamento Espectral ajudou na geração de harmonias de trítonos em um plano de fundo com uma minimização da Aspereza e, portanto, uma eliminação dessa forte dimensão de dissonância sensorial.

A qualidade timbrística dos instrumentos originais permanece presente. Porém, é clara também uma mudança de qualidade harmônica, ou melhor, de uma inarmonicidade da sonoridade. Esse aspecto traz uma nova qualidade textural ao corpo da orquestra. Esse trecho se repete ainda duas vezes no decorrer da composição, mais ao meio e para o fim, com algumas variações. A peça, na íntegra, se encontra em anexo.

\section{2 - Impacto de Modelos Psicoacústicos de Dissonância em Criação Musical}

A pesquisa psicoacústica nos ajuda a buscar fundamentos científicos para a percepção de qualidades sonoras. Das muitas aplicações da Psicoacústica, o seu surgimento também permitiu uma nova forma de estudar a percepção musical e princípios teórico-musicais que se baseiam em percepção de certos objetos sonoros. A Dissonância, assim como a ideia de Harmonia e Consonância, são fenômenos perceptivos que podem ser estudados nesse viés.

Trazemos nessa subseção uma discussão final sobre o impacto e relevância dos modelos apresentados, assim como a velha discussão sobre o inato versus o adquirido - apresentada junto com algumas considerações relacionadas ao foco de pesquisa. 


\subsubsection{Inato versus Adquirido}

Antes da Psicoacústica, modelos teóricos também buscavam uma relação entre aspectos universais e a prática musical. A teoria de Pitágoras se baseia em números e não tem embasamento perceptivo de fato. Apesar de coerente a princípio, a teoria Pitagórica gerou um problema restritivo. Sua influência deu origem a um sistema de afinação (Afinação Pitagórica) formado apenas por frações com os fatores primos $2 \mathrm{e}$ 3, em que todos os passos da escala são obtidos por sucessão de quintas [3:2]. Estes números mais simples, porém, podem gerar intervalos menos consonantes, como a terça maior ([81:64] em vez de [5:4]). Nosso experimento também foi capaz de comprovar que mesmo em três versões de trítono, a forma de razão mais simples foi tida como harmônica.

Como o desenvolvimento da Música Ocidental também foi muito influenciado pela prática musical em si, encontrou-se uma necessidade de incluir o intervalo de [5:4]. Esse fato se deu por um princípio perceptivo de dissonância. Entretanto, o curioso é que, com o desenvolvimento da música tonal, diversos sistemas de afinação temperados acabaram por excluir esse intervalo. No temperamento igual, as terças e sextas possuem diferenças de até 16 cents em relação às versões de intervalos justos ${ }^{42}$.

Esses fatos trazem à tona uma discussão e uma prova que a palavra final não é um modelo teórico, como o de Pitágoras, nem mesmo um fato científico e perceptivo, mas sim uma prática e linguagem musical. O conceito de Dissonância e Harmonia evoluiu muito mais a partir de uma prática musical - artística e estética - do que uma teoria ou modelo científico, e essa conclusão pode ser confirmada com a revisão histórica de Tenney (1988). Por outro lado, é difícil fugir de alguma relação com nosso sistema perceptivo.

Além de Pitágoras, podemos ressaltar o trabalho de Rameau (1722), cujo tratado de Harmonia buscou clarear princípios teóricos musicais baseados em leis naturais. Suas premissas teóricas possuem importância até hoje, como na ideia de inversão de acordes, e o Baixo Fundamental, que atualmente é trazida por Terhardt (1984) a partir de um embasamento psicoacústico.

Após Rameau, Helmholtz (1877) traz um trabalho pioneiro em Psicoacústica que explica princípios sensoriais da Dissonância. E Parncutt (1989) nos traz uma boa revisão do estado da arte no que diz respeito à relação entre Psicoacústica e teoria

42 Uma revisão detalhada sobre Sistemas de Afinação e sua história pode ser encontrada na dissertação de mestrado do autor (Porres 2008). 
musical. Alguns aspectos têm sido comprovados e identificados, como os atributos aqui pesquisados.

De um modo ou de outro, o fenômeno musical depende em algum grau do que se consegue ouvir e perceber. Por isso, teóricos que buscam essa relação acabam encontrando explicações psicoacústicas. Mas ainda não resolvemos a questão do inato versus adquirido, do sensorial versus cultural, ou dos "racionalistas" versus os “empiristas”, como descrito no trabalho de DeWitt e Crowder (1987).

Porém, não há de fato uma ideia de que um fator deva prevalecer sobre outro e que deva haver um "vencedor" nessa "disputa". É uma noção comum e atual que ambos fatores têm relevância, só não sabemos ainda exatamente quanto um depende do outro.

O ponto em debate é que não precisamos nos ater a uma validação de uma prevalência histórica de algum sistema ou teoria como a explicação psicoacústica da música tonal. Uma preocupação dessa ordem chega a ser anacrônica no panorama composicional contemporâneo. A ciência psicoacústica começa a trazer os primeiros resultados mais relevantes na segunda metade do século XX, como o importante estudo clássico de Plomp e Levelt (1965). Nessa altura, a pesquisa de linguagem composicional do Século XX já tinha conhecido a música concreta de Schaeffer, a escola alemã de música eletrônica, o serialismo integral e até mesmo processos estocásticos e sistemas de CAC (Griffiths 1995).

\subsubsection{Teoria Psicoacústica e Teoria Musical, um Anacronismo}

Há aproximadamente 150 anos que o conhecimento científico abriu margem para uma investigação de ordem Psicofísica. Desde então, temos uma nova abordagem que nos dá ferramentas para explorar a relação entre conceitos teórico-musicais (com uma forte influência de ordem abstrata, empírica, cultural, estética e histórica) e atributos acústicos. Isso tudo depende de um conhecimento do aparato fisiológico e cognitivo humano e de como ele responde a certos atributos físicos mensuráveis e claramente distintos.

Apesar de constituir um período relativamente longo, os avanços em relação à percepção de Dissonância têm sido modestos. A suposição de Helmholtz (1877) de que a Aspereza é um atributo perceptivo importante na sensação de Dissonância ainda prevalece. A relação sinonímica entre Aspereza e Dissonância Sensorial ainda é forte, e a influência de outros atributos tem sido, de certa forma, negligenciada. 
Logo após o trabalho de Helmholtz, já temos na pesquisa de Stumpf (1890) outra premissa, que pressupõe uma teoria baseada em relações harmônicas e uma "Fusão Tonal", em que componentes espectrais harmônicos se fundem em um único objeto perceptível. O autor inaugura experimentos nesse sentido. Mas, em todo caso, não temos certeza ainda de como esse processo ocorre em nosso sistema auditivo e cognitivo.

Este é um cenário diferente da Aspereza, em que há uma relação clara com mecanismos fisiológicos (encontrados na estrutura do ouvido interno, mais especificamente na cóclea) e como o ouvido interno se divide em bandas críticas. Além de a Aspereza possuir uma forte influência na sensação de dissonância, essa sua correspondência fisiológica em um nível mais baixo facilita sua modelagem e contribui ainda mais para seu destaque na literatura.

Novos estudos na área de neurociência e cognição musical apontam para novas relações entre características acústicas sonoras e nosso sistema perceptivo. Essa área é relativamente nova, tendo seu expoente apenas na década de 1980. Outro fator é que esse campo de pesquisa tem se valido de novos avanços científicos na área de estudo do cérebro, mas também de novas ferramentas tecnológicas de análise. Entretanto, últimos avanços científicos (Dermott et. al 2010) ainda buscam compreender melhor a relação entre Aspereza e Harmonicidade.

Um trabalho recente, como o de Parncutt (1989), ainda toca aspectos básicos e tradicionais de dissonância e teoria musical, como o Baixo Fundamental de Rameau (1722). Há de se compreender o pequeno impacto de tais teorias na música do século $\mathrm{XX}$, já que estudos psicoacústicos ainda engatinhavam na segunda metade do século tratando de paradigmas musicais tradicionais e antigos. Por mais que se tenha uma boa noção psicoacústica da Dissonância, até que ponto podemos considerar seu impacto em uma linguagem musical?

\section{3 - Por uma Abordagem Voltada ao Concreto}

Levando em consideração o estado da arte em pesquisas psicoacústicas - e as questões envolvidas -, sua adoção não deve ter o intuito de validar a teoria ou prática musical. As experiências psicoacústicas podem surtir efeito no desenvolvimento de novas técnicas composicionais, em uma abordagem voltada para o aspecto concreto do material sonoro. Esse tipo de motivação tem atraído o interesse particular de alguns compositores que se dedicam ao aspecto físico do som e de sua percepção, e que 
desenvolvem sistemas para controlar e manipular material sonoro de modo concreto.

Essa perspectiva não coloca a teoria psicoacústica como um pilar central e imprescindível para qualquer tipo de manifestação musical, não visa explicar a história e desenvolvimento da música tonal, apenas procura uma nova ferramenta para o desenvolvimento de novos métodos e técnicas de composição. E aqui podemos buscar outros exemplos de compositores que desenvolveram sistemas próprios de um modo similar.

Paul Hindemith (1895 - 1963), por exemplo, desenvolveu um sistema baseado no conceito de Consonância e Dissonância (1945) e poderia ter se beneficiado de alguns conceitos e teorias recentes da Psicoacústica. Um elemento central de seu método consistiu em ordenar todos os intervalos do Sistema Temperado em uma escala do mais Consonante ao mais Dissonante. Hindemith também organizou seis diferentes classes de dissonância para acordes, levando em consideração, por exemplo, se contém alguma relação de trítono, ou se há uma sugestão clara de um Baixo Fundamental.

Os modelos aqui apresentados visam justamente auxiliar nesse processo de organização material, como inclusive explorado por Barlow (1980) e Ferguson (2000). A vantagem é que os modelos psicoacústicos permitem medir essas características para qualquer tipo de sonoridade e/ou sistema de afinação. Afinal, dependendo de peculiaridades do conteúdo espectral (como loudness, brilho, aspereza, harmonicidade e registro), o resultado aferido será diferente. Por mais que ainda haja uma boa margem para melhorias, é evidente como uma abordagem com a de Hindemith poderia se beneficiar dos resultados e informações trazidas por esta pesquisa.

Apontamos como essa teoria possui um grande impacto em Sistemas de Afinação. Em compensação, diversas pesquisas microtonais que exploraram novas relações auditivas no Século XX não se valeram dos avanços psicoacústicos de suas épocas (Porres 2007), pois ainda não ofereciam uma ferramenta de pesquisa de linguagem como agora é possível, principalmente após o trabalho de Sethares (1999).

Podemos ressaltar, em especial, o trabalho de Partch (1974), que desenvolve um Sistema de Afinação Justa com 43 intervalos por oitava. Esta divisão e o sistema com 28 centros tonais não é nada compatível com o sistema temperado e a linguagem tradicional de música tonal. A perda de praticidade dessa pesquisa buscava um ganho de ordem perceptiva de consonância, como é a principal motivação de uma afinação justa frente ao sistema temperado, pois tal sistema, para tons musicais (complexos e harmônicos), promove um maior alinhamento de parciais e maior harmonicidade. 
Partch explorou esse aspecto em sua pesquisa e incluiu intervalos com fatores primos até o número 11.

O trabalho de Partch data da década de 1970, porém o autor não incorporou avanços da psicoacústica em seu trabalho. Partch discute sua teoria de consonância no capítulo 9 ("One Footed Bridge") e traz ao debate teorias antigas e modernas sobre Consonância e Dissonância. Partch comenta o trabalho de Helmholtz, mas critica sua abordagem cientificista e se opõe ao destaque dado ao papel da Aspereza - todavia, sem refutar nem contestar o fato da existência de Batimentos e Aspereza. O autor prefere se basear no trabalho de Stumpf (1890), mesmo este tendo sido negligenciado na literatura.

Mais do que um debate científico propriamente dito, Partch (1974) está mais preocupado em discutir diversas teorias musicais de um modo geral. E, para todos os efeitos, admite uma postura - ou produz uma espécie de manifesto musical - em que prevalece o empirismo sobre uma filosofia racional e científica. Não é à toa que levantamos a questão do impasse de uma postura como essa versus uma abordagem psicoacústica. Porém, conclui-se que, atualmente, essa "guerra" entrou em um acordo de paz. Tanto que teorias psicoacústicas de Harmonicidade e Tonalness poderiam embasar parte de suas premissas.

Infelizmente, esse contexto fez que Partch acabasse por não ter um devido respaldo em modelos psicoacústicos. Porém, da mesma forma em que Hindemith poderia usufruir de informações e fatos pertinentes da Psicoacústica, uma abordagem como a de Partch pode, igualmente, relevar os princípios teóricos que despontam atualmente.

A figura 87 é um gráfico empírico, desenvolvido por Partch, chamado "One Footed Bridge" que, na prática, é uma Curva de Dissonância que afere medidas para os intervalos de seu sistema de afinação. O gráfico divide a oitava no meio e coloca a curva de modo espelhado, de forma que um mesmo perfil de contorno indica a ideia de Partch sobre inversão de cada intervalo possuir uma mesma medida de consonância

Se compararmos os dados com modelos psicoacústicos, teremos um conflito, certamente, como já apontado em pesquisa anterior (Porres 2007). Não que um sistema como o de Partch precise de uma validação científica para que seja aceito, o ponto trazido à discussão e conclusão de nosso trabalho é outro. Uma abordagem científica pode ajudar no desenvolvimento de um sistema composicional de ordem concreta. Mas, mesmo que um sistema composicional possua certas incongruências teóricas, isso 
não necessariamente lhe extrai a potencialidade musical ou estética. Não obstante, Barlow (1987) opina que Partch não foi capaz de adotar seu sistema de modo convincente, ideia com que estamos de acordo.

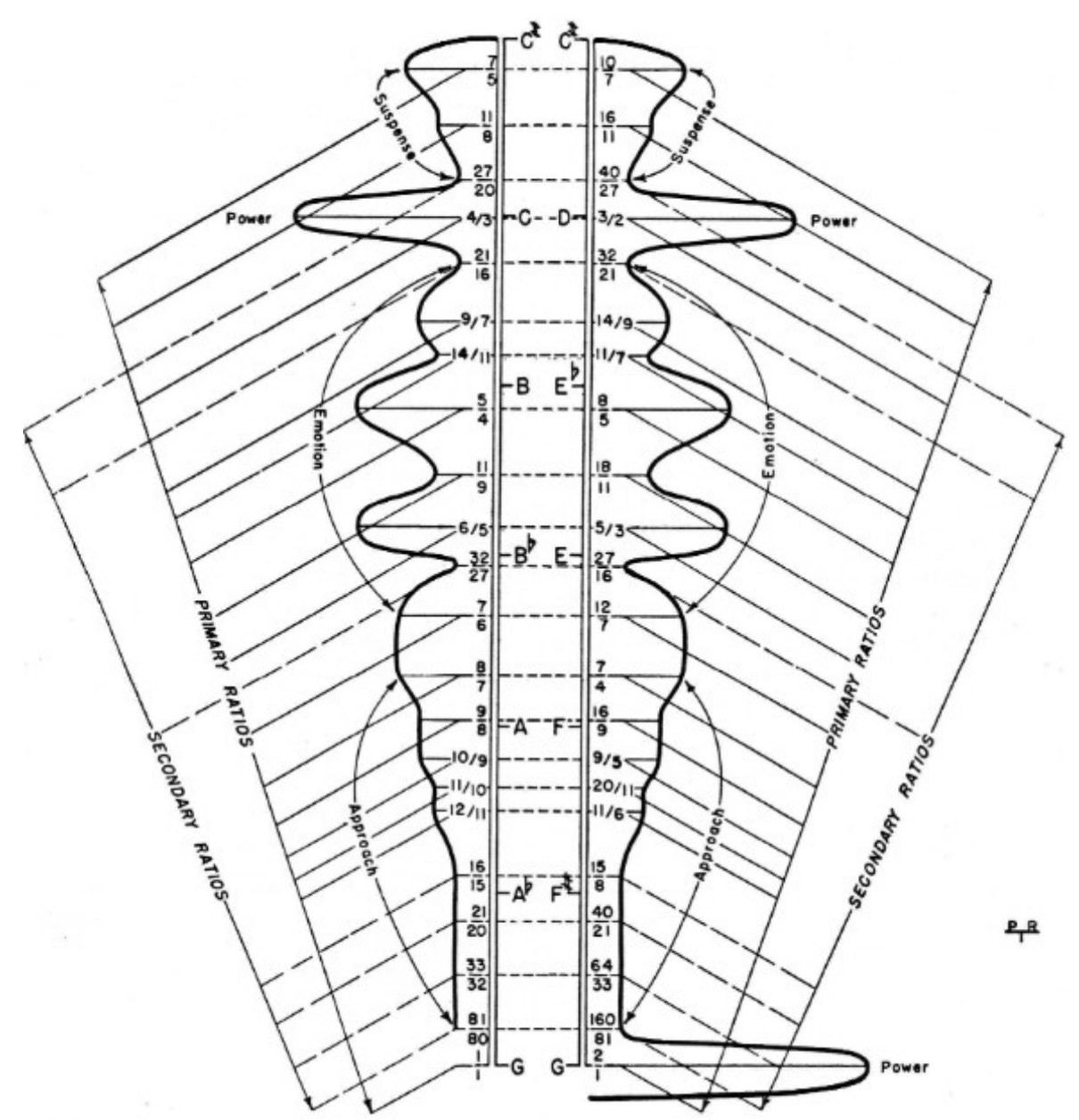

Figura 87 - Curva de Consonância de Partch (“One Footed Bridge”).

Vem ao caso falar de outro exemplo paralelo. Como estamos tratando de abordagens concretas, nada mais justo que comentar o trabalho de Pierre Schaeffer (1966), o pai da música concreta. Schaeffer é um exemplo do anacronismo entre a teoria psicoacústica e importantes aplicações musicais. Se Partch não pôde se valer de grandes resultados e referências, Schaeffer o fez muito menos, por ser anterior e ainda visionário no sentido de uma revisão da linguagem musical com uma organização sonora refinada.

A Psicoacústica ainda hoje possui dificuldades em dar conta da complexidade de fatores de ordem musical tradicional. Não consideramos, nesta tese, que uma abordagem como a de Schaeffer deva ser contestada e validada cientificamente, mas 
nos perguntamos se ela poderia ganhar corpo, ou se sofreria algum desdobramento.

A teoria e o método de composição de Schaeffer se baseiam em um conceito de tipos de escuta e uma forma de solfejo atento a aspectos chamados tipo-morfológicos do som. Com a abstenção de um embasamento psicoacústico, sua teoria tampouco preza por uma forma objetiva de medir diversos parâmetros a partir de modelos concretos. Todavia, atualmente, o cenário permite algumas relações como as feitas por Ricard (2004).

Em parte apoiado pelo Projeto CUIDADO, esse autor relaciona Descritores de Áudio à tipo-morfologia de Schaeffer (1966) e busca essa relação entre os conceitos schaefferianos e modelos psicoacústicos. Da mesma maneira que o projeto CUIDADO, há um foco no trabalho de Ricard em Music Information Retrieval, em especial nos sons cuja fonte não é identificável (efeitos sonoros), ou seja, não há uma preocupação musical ou composicional de fato.

O trabalho estabelece um esquema descritivo que amplia a classificação de Schaeffer (1966) para analisar, descrever e classificar automaticamente um corpo de sons eletrônicos separados de contexto musical e parte de uma tipo-morfologia em descritores como: duração subjetiva, loudness, altura, clareza de altura, aspereza, perfil dinâmico, ataque, brilho, flutuação espectral, metalidade, riqueza, dentre outros.

Esse trabalho não visa modelar computacionalmente a teoria de Schaeffer em novas ferramentas para criação musical. Em compensação, trouxemos à nossa discussão exemplos interessante que se baseiam em Descritores de Áudio e são capazes de comparar e medir atributos físicos e atributos perceptivos de baixo nível. Tais iniciativas têm promovido técnicas consistentes como reconhecimento e comparação de timbres em processos como o de Síntese Concatenativa.

De um modo geral, os descritores são capazes de encontrar parâmetros sonoros diversos, relacionados a uma dimensão textural, ou de timbre. Enfim, a uma dimensão mais esmiuçada de descrição sonora que, até então, se volta mais a um aspecto tonal, como a identificação de Altura. O trabalho de Schaeffer amplia a linguagem musical com outros objetos sonoros que não dependem apenas de um paradigma da linguagem tonal (a qual se relaciona principalmente à percepção de Altura), abrindo assim a novos aspectos texturais dinâmicos.

Não precisamos também nos ater apenas a uma noção de Consonância e Dissonância, ou percepção de altura. Uma abordagem voltada ao concreto abre portas para uma parametrização sonora mais detalhada. Tenney (1988) nos traz também uma 
análise pormenorizada de conceitos de Dissonância, em que a relaciona a elementos como a prática e teoria de condução de vozes. O autor comenta apenas da Aspereza como elemento de uma Dissonância Psicoacústica, mas reconhece a possibilidade de inclusão de outros parâmetros de pesquisa psicoacústica e cognitiva para dar um embasamento a diferentes conceitos e aspectos musicais. Um exemplo de uma pesquisa nessa linha é dado por Huron (2001), que faz um paralelo com alguns conceitos psicoacústicos e condução de vozes.

Fato é que apenas uma modelagem de dissonância psicoacústica como aqui apresentada, tida como dependente de duas dimensões principais, não deve valer como pilar estrutural único de um sistema de composição. De modo similar, esse era apenas um dos elementos e recursos do sistema e linguagem de Paul Hindemith (1945). Nos exemplos trazidos aqui nesta pesquisa de Sean Ferguson (2000) e Clarence Barlow (1980), ambos os sistemas incluíram, igualmente, mais elementos que apenas os descritores de dissonância.

O trabalho de Barlow, apesar de incluir modelos psicoacústicos, acaba envolvendo uma conduta empirista. Sua técnica e estética se voltam a um paradigma de composição algorítmica. Seu sistema e obras musicais carregam um alto grau de complexidade. Esse sistema complexo envolve vários conceitos desenvolvidos pelo autor que não encontraram nem encontram ainda relação com a literatura de Psicoacústica e cognição musical. Mesmo assim, o autor não descarta a utilidade de uma pesquisa psicoacústica em sua linguagem e técnica.

Em especial, Sean Ferguson (2000) busca uma abordagem mais concreta, focada em princípios psicoacústicos como uma forma de conectar as intenções “criativas, técnicas composicionais, e as reações do ouvinte". Essa preocupação, inclusive, se relaciona ao processo descrito por Nattiez (1990), pois envolve exatamente o nível poiético (intenções criativas), neutro (produto de técnicas composicionais) e estésico (reações do ouvinte). Simon Emmerson (1982) também destaca um possível papel da Psicoacústica nesse processo.

Ferguson admite o grande desafio e incipiência desse tipo de abordagem. $\mathrm{O}$ autor explora com grande ênfase os modelos de Aspereza e Comonalidade de Altura como base de uma estruturação harmônica e de Dissonância. Ferguson também explora e propõe outros conceitos e ideias para harmonização. Seu sistema lhe permite harmonizar uma linha melódica a partir de critérios paralelos como "cardinalidade" e "variância de intervalo adjacente" (relacionada à Distância de Altura). A teoria de 
contorno melódico e rítmico também o assiste na estruturação e unificação da peça.

O compositor também vislumbra novas possibilidades de adoção de outros conceitos e ferramentas. A respeito de Comonalidade de Altura, além de considerar uma relação de Distância de Altura, ele aponta para a possível junção de uma terceira dimensão, em um recente modelo de condução de vozes (Bigand et al 1996), como uma forma de contabilizar também a mudança da voz soprano de um acorde, que possui um destaque maior.

Mas Ferguson poderia também ter explorado atributos aqui apresentados, como o Tonalness e Fundamental de Acorde para medir a força de um centro tonal, ou analisado a Comonalidade de Altura entre as vozes de um acorde, apenas para citar alguns elementos que estavam disponíveis e ficaram de fora.

Com avanços atuais, é possível ainda abrir-se a novas perspectivas de experimentações e relações. Aplicações como a Síntese Concatenativa e as ferramentas Orchidée e SPORCH se baseiam em uma espécie de "Comonalidade de Timbre", por exemplo. Esse exemplo reforça a conclusão de Ferguson sobre o fato desse campo estar emergindo com novas possibilidades de emprego em composição musical. Outro fator de contribuição é avanço de processamento computacional, que permite a criação de novas ferramentas e aplicações em tempo real. 


\section{Capítulo 15) Conclusão}

A principal e original contribuição desta tese se encontra na integração de modelos psicoacústicos de dissonância em novas ferramentas criativas para eletrônica ao vivo. Outras contribuições e objetivos foram também atingidos. Uma revisão crítica da teoria psicoacústica é fornecida e seu impacto em criação musical é discutido frente aos desenvolvimentos da pesquisa. O texto e ferramentas desenvolvidas também contribuem na disseminação do potencial criativo da teoria.

\section{1 - Teoria Psicoacústica}

A pesquisa contou com uma revisão crítica da teoria psicoacústica de percepção de dissonância. Foram apontados problemas em diferentes instâncias, como na própria definição de dissonância e inconsistências e limitações da pesquisa atual na área, assim como novos debates e avanços que têm surgido em neurociência.

Tenney (1988) apresenta noções distintas de Dissonância e uma necessidade de enriquecimento da linguagem. A Dissonância Psicoacústica, por ele apresentada, se baseia apenas na Aspereza, mas aponta para novas relações em um refinamento de atributos perceptivos e conceitos de Dissonância. As outras noções de dissonância se baseiam, fortemente, em relações tonais (entre sonoridades harmônicas), que se relacionam com atributos de Tonalness, Fundamental do Acorde e Comonalidade de Altura.

Como os atributos perceptivos se relacionam em uma medida de Dissonância ainda é incerto. Quanto ao problema, apontamos alguns estudos importantes e novos caminhos para investigação. Inconsistências e limitações foram questionadas e futuras projeções foram feitas. Reorganizamos o quadro de Terhardt (1984) e focamos em duas principais dimensões de dissonância (Aspereza e Harmonicidade).

Curvas de Dissonância foram apresentadas como uma forma de descrever a dissonância de intervalos musicais baseada no conteúdo espectral, que depende, principalmente, das duas dimensões propostas. Um teste perceptivo baseado nessas duas dimensões foi apresentado. Os resultados são comparados com modelos de Aspereza e Tonalness, e conclusões finais buscam formas de melhor considerar uma revisão de modelagem de Aspereza, a sensação de Batimentos e a dimensão de Harmonicidade, a serem validadas em trabalhos futuros. 


\section{2 - Impacto e Contribuição Criativa}

A teoria psicoacústica pode prover modos concretos de manipular atributos sonoros, com impacto direto no resultado perceptivo. Novas técnicas baseadas em uma abordagem concreta podem se beneficiar com estudos nessa área. Novos desenvolvimentos relacionados a MIR e Descritores de Áudio têm emergido, especialmente no que tange ao reconhecimento de Timbre. Um próximo estágio de desenvolvimento deve considerar modelos de ordem superior, como os apresentados nesta pesquisa, em que podemos, por exemplo, comparar a Comonalidade de Altura entre diversas sonoridades em tempo real.

Esse conjunto de atributos nunca foram implementados anteriormente em sistemas de Eletrônica ao Vivo. Algumas ferramentas desenvolvidas os medem em tempo real e apresentam formas de alterar seu conteúdo espectral de modo pertinente. Um potencial criativo que tem sido negligenciado foi explorado durante este trabalho de pesquisa. O sistema de Eletrônica ao Vivo [Brane ] engloba as principais técnicas apresentadas em uma única ferramenta acessível e foi adotado pelo autor em improvisação e composição mista.

\section{3 - Projeções Futuras}

O estado da arte foi implementado em objetos de Pd. Futuras atualizações devem ser feitas de acordo com novos resultados de pesquisa em psicoacústica, discutida na revisão teórica. Não foi possível explorar todas as capacidades criativas, mas importantes primeiros desenvolvimentos foram feitos, enquanto outros foram apontados. Muitas ideias surgiram e se desenvolveram casualmente por meio de experimentações, e novos desenvolvimentos devem ocorrer nesse sentido na evolução desses processos. Igualmente, enquanto essa teoria e ferramenta se tornam mais acessível, é certo que outros frutos surgirão de uma forma igualmente casual.

O sistema [Brane ] é, atualmente, um programa com uma base de apenas um usuário: o autor. Porém, um esforço foi dedicado a uma boa usabilidade e acessibilidade a outros. Apesar de ter sido adotado com sucesso em aplicações musicais, a ferramenta ainda é um primeiro protótipo apresentado ao público em geral e pode parecer complexa em um primeiro momento. Por isso, o texto e os módulos independentes desenvolvidos são importantes. Mas também projetamos que novas atualizações sejam feitas ao software, que podem se desdobrar em novos módulos em versões mais simples e especializadas a alguma funcionalidade. 


\section{Referências}

AMATRIAIN, X., Massaguer, J., Garcia, D., and Mosguera, I. (2005) "Features for Audio and Music Classification" Proceedings of the 6th Interna- tional Conference on Music Information Re- trieval London, UK, 2005

AURES, W. 1985a "Ein Berechnungsverfahren der Rauhigkeit," Acustica, vol. 58, pp. 268-281, 1985

AURES, W. 1985b "Ein Berechnungsverfahren für den sensorischen Wohlklang beliebiger Schallsignale", Acustica 59:130-41

BARLOW, C. (1980) “Bus journey to Parametron”. Feedback Papers vol. 21-23, Köln, 1980.

• (1987) "Two Essays on Theory", Computer Music Journal.

- (1990) Autobusk - An Algorithmic Real-Time Pitch \& Rhythm Improvisation Programme. In: ICMC Proceedings, Glasgow 1990, p. 166-168.

- (2008). Von der Musiquantenlehre (2 volumes, 130 páginas, em alemão) Feedback Paper 34, 2008. Feedback Studio Verlag, Colônia, Alemanha

BIGAND, E., PARNCUTT, R. LERDAHL, F. (1996) "Perception of Musical Tension in Short Chord Sequences: The Influence of Harmonic Function, Sensory Dissonance, Horizontal Motion, and Musical Training," Perception \& Psychophysics, Vol. 58, No. 1 (1996): 125-141.

BORING, E. \& STEVENS, S. (1936) 'The nature of tonal brightness', Proceedings of the National Academy of Science, 22, 1936, pp 514-521

BREGMAN, A. S. (1990). Auditory Scene Analysis. Cambridge, MA: MIT Press.

BRENT, W. (2009) "A Timbre Analysis and Classification Toolkit for Pure Data: An introduction to the timbreID collection of objects as of December 2009, including descriptions of the example patches" < http://williambrent.conflations.com/papers/timbreID.pdf>.

BULLOCK, J. (2007) "Libxtract: A lightweight library for audio feature extraction," in Proceedings of the International Computer Music Conference.

CABRERA, D. (1999) "PsySound: a Computer Program for the Psychoacoustical Analysis". Anais da Australian Acoustical Society Conference, pp 47-54. Melbourne, 24-26 Novembro.

CONT, A. (2008a) ANTESCOFO: Anticipatory Synchronization and Control of Interactive Parameters in Computer Music. Arshia Cont. In Proceedings of International Computer Music Conference (ICMC), August 2008.

. (2008b) Modeling Musical Anticipation: From the time of music to the

music of time. Arshia Cont. $\mathrm{PhD}$ thesis, University of Paris 6 and University of California in San Diego, October 2008.

COSTA, R. L. M. (2009). A ideia de corpo e a configuração do ambiente da improvisação musical Opus (Belo Horizonte. Online), v. 14.2, p. 87-99, 2009.

DANIEL, P. \& WEBER, R. (1997) "Psychoacoustical roughness: Implementation of an optimized model," Acustica, vol. 83, pp. 113-123 
DeWITT, L. A., \& CROWDER, R. G. (1987) "Tonal fusion of consonant musical intervals: The oomph in Stumpf." Perception and Psychophysics, 41(1), 73-84, 1987.

McDermott, J.H., LEHR, A.J., Oxenham, A.J. (2010) Individual Differences reveal the basis of consonance. Current Biology, 20, 1035-1041.

DIEMO S., BELLER G., VERBRUGGHE B., BRITTON S. (2006) Real-Time Corpus-Based Concatenative Synthesis with CataRT. In Proceedings of the COSTG6 Con- ference on Digital Audio Effects (DAFx), pages 279-282, Montreal, Canada, September 2006.

DUDLEY, H. W (1939) “The Vocoder” Bell Labs Rec., vol. 18, pp. 122-126, 1939, Reprinted in [409, pp. 347-351]

EBELING, M (2009). Calculating Tonal Fusion by The Generalizes Coincidence Function Mathematics and computation in music third international conference,: proceedings. Berlin, Springer.

ECCLES, J.C. 1973. The Understanding of the Brain. McGraw-Hill, New York

ELRICH, P. (1997) On Harmonic Entropy; disponível em <http://sonicarts.org/td/erlich/entropy-erlich.htm>.

EMMERSON, S. (1982) Analysis and the composition of electroacoustic music. Tese de doutorado. The City University, 1982.

FERGUSON, S, "Concerto for Piano and Orchestra", Ph.D. Thesis. 2000. McGill.

FERGUSON, S. \& PARNCUTT, R. (2004). Composing 'In the Flesh': Perceptuallyinformed har- monic syntax. Proceedings of Sound and Music Computing (Paris/France, 20-22 Oktober '00).

FINGERHUTH, S. Tonalness and consonance of technical sounds, Logos Verlag Berlin $\mathrm{GmbH}, 2009$

FLANAGAN, J.L, GOLDEN R. M. (1966) "Phase Vocoder," Bell System Technical Journal, November 1966, 1493-1509.

FLETCHER, H; Munson, W.A. (1933), Loudness, its definition, measurement and calculation. Journal of the Acoustical Society of America N. 5, 82-108, 1933.

GREENWOOD, D. D. (1961) Critical bandwidth and the frequency coordinates of the basilar membrane. Journal of the Acoustical Society of America, 33(4), 1344-1356. 1961.

GREY, J. (1975) “An Exploration of Musical Timbre Using Computer-based Techniques for Analysis, Synthesis and Perceptual Scaling”. PhD thesis, Stanford University.

GRIFFITHS, P. (1995) Enciclopédia da Música do Século XX. Rio de Janeiro, Martins Fontes, 1995.

HELMHOLTZ, H.L.F. (1877) On the Sensations of Tone as a Psychological basis for the Theory of Music. New York, NY: Dover Publications. $2^{\text {a }}$ edição (1954)

HINDEMITH, P. (1945) The Craft of Musical Composition, Book 1: Theoretical Part. New York: Associated Music Publishers, Inc., 1945.

HUTCHINSON, W; KNOPOFF, L. (1978) The Acoustic Component of Western Consonance, Inteface 7: 1-29, 1978. 
HURON, D. (2001) Tone and Voice: A Derivation of the Rules of Voice-Leading from Perceptual Principles. Music Perception Fall, Vol. 19, No. 1, 1-64, 2001.

IAZZETTA, F. (2008). Sonologia: uma tentativa de introdução. Anais do Seminário Música Ciência e Tecnologia, v. 3, p. 3-6, 2008.

IVERSON, P. \& KRUMHANSL, C. (1993) "Isolating the dynamic attributes of musical timbre". Journal of the Acoustical Society of America, 94(5):2595-2603.

KASKE, S (1985) A Conversation with Clarence Barlow Computer Music Journal Vol. 9, No. 1 (Spring, 1985), pp. 19-28

KAMEKOA, A.; KURIYAGAWA, M. (1969a) Consonance theory. Part I: Consonance of dyads. Journal of the Acoustical Society of America, 45, 1451-1459, 1969a.

. (1969b) Consonance theory. Part II: Consonance of complex tones and its calculation method. Journal of the Acoustical Society of America,45, 1460-1469, $1969 \mathrm{~b}$.

LEMAN, M. (2000) "Visualization and calculation of the roughness of acoustical musical signals using the synchronization index model (SIM), Proceedings of the COST G-6 Conference of Digital Audio Effects (DAFX-00), Verona.

LINDSAY, T., BURNETT, I., QUACKENBUSH, S., JACKSON, M. (2003) "Fundamentals of Audio Descriptors", Introduction to MPEG-7 Multimedia Content Description Interface, West Sussex, England.

MEDDIS, R. HEWITT, M. (1991) "Virtual Pitch and Phase Sensitivity of a Computer Model of the Auditory Periphery. I: Pitch Identification" Journal of Acoustical Society of America, Vol. 89, No. 6. (June 1991), pp. 2866-2882.

MITROVIC, D. ZEPPELZAUR, M. BREITENDER, C. (2010) "Features for ContentBased Audio Retrieval" Advances in Computers Volume 78 Improving the Web", Elsevier, 2010, S. 71 - 150.

MONTEIRO, A. C., MANZOLLI, J. (2010) Aplicação de Descritores em Sistema Interativo para Música Mista. In: Encontro Internacional de Música e Arte Sonora EIMAS, 2010, Juiz de Fora. Revista EIMAS 2010, 2010. v. 1.

NATTIEZ, J. (1990) Music and Discourse: Toward a Semiology of Music (Musicologie générale et sémiologue, 1987). Traduzido por ABBATE, C., 1990.

NOVARRO, A. (1927) Sistema Natural de la musica - Sistema Natural base Del natural-aproximado. México D.F.

PARVIAINEN, O. (2006). Time and pitch scaling in audio processing Software Developer's Journal 4/2006.

PARNCUTT, R. (1989) Harmony: a psychoacoustical approach, Berlin: Springer, 1989.

PARNCUTT, R. (1993) "Parncutt's implementation of Hutchinson \& Knopoff roughness model'. Disponível em: <http://www-gewi.unigraz.at/staff/parncutt/rough1doc.html>.

PARNCUTT, R, \& STRASBURGER, H. (1994). Applying psychoacoustics in composition: "Harmonic" progressions of "non-harmonic" sonorities. Perspectives of New Music, 32 (2), 1-42. 
PARTCH, H. (1974) Genesis of a Music, Da Capo Press, New York, 1974.

PEETERS, G. (2003) "A large set of audio features for sound description (similarity and classification) in the CUIDADO project" IRCAM, Paris.

. (2004) "A large set of audio features for sound description (similarity and classification) in the CUIDADO project" CUIDADO I.S.T. Project Report $2004<$ http://recherche.ircam.fr/equipes/analyse-synthese/peeters/ARTICLES/ Peeters_2003_cuidadoaudiofeatures.pdf $>$.

PIERCE, J. R. (2001). "Consonance and scales". In Perry R. Cook. Music, Cognition, and Computerized Sound: An Introduction to Psychoacoustics. MIT Press. p. 183

PRESSNITZER, D. (1999) "Perception de rugosite' psychoacoustique: d'un attribut e'le mentaire de l'audition a l'e'coute musicale" Ph.D. thesis, Universite' Paris 6.

PRESSNITZER, D \& McADAMNS, S. (1999) "Two phase effects in roughness perception" J. Acoust. Soc. Am. 105(5): 2773-2782.

PLOMP, R.; LEVELT, W.J.M. (1965) Tonal Consonance and Critical Bandwidth. Journal of the Acoustical Society of America N. 38, 548-568, 1965.

POPPER, K. 1972. Objective Knowledge, an Evolutionary Approach. Clarendon, Oxford

PORRES, A. T. (2007) "Processos de Composição por meio do Modelo de Dissonância Sensorial”. Dissertação de Mestrado, UNICAMP, 2007.

PUCKETTE, M. (2007) Patch for Guitar, $2^{\text {nd }}$ International Pd Convention, Montreal

PUCKETTE, M. (1995). "Phase-locked Vocoder." Proceedings, IEEE ASSP Workshop on Applications of Signal Processing to Audio and Acoustics. 34 Scientific Press.

. (2006) The Theory and Technique of Electronic Music, World

RAMEAU, J.P. (1722) Traité de l'harmonie réduite à ses principes naturels

RICARD, J. (2004) Towards computational morphological description of sound, Tese de Doutorado, Universitat Pompeu Fabra, Barcelona, 2004.

ROADS, Curtis (1996). The Computer Music Tutorial. MIT Press

ROBINSON, D. W \& DADSON, R. S. (1956) "A re-determination of the equalloudness relations for pure tones British Journal of Applied Physics, Volume 7, Issue 5, pp. 166-181 (1956)

RUVIARO, B. (2010) "Intellectual Improperty: Musical Borrowing as Manifest in Acoustic and Electroacoustic Compositions" tese de doutorado, Stanford.

SCHAEFFER, P. (1966) Traité des objets musicaux. Paris: Seuil, 1966.

SCHNEIDER, A. FRIELER, K. (2009) Perception of Harmonic and Inharmonic Sounds: Results from Ear Models Computer Music Modeling and Retrieval Genesis of Meaning in Sound and Music.

SCHOUTEN, J. F. (1940) The residue, a new component in subjective sound analysis. Proceedings Koninklijke Nederlandse Akademie Wetenschappen, 43, 356-365, 1940.

SETHARES, W.A. (1999) Tuning, Timbre, Spectrum, Scale. London: Springer-Verlag. 
$2^{\mathrm{a}}$ Ed. com CD-ROM, 2005.

SETHARES, W. A. J. Milne, S. Tiedje, (2009) "Spectral Tools for Dynamic Tonality and Audio Morphing" Computer Music Journal, 2009, Volume 33, Number 2, Summer 2009, pp. 71-84.

STUMPF, C. (1890) Tonpsychologie vol 2. Leipzig: Hirzel, 1890.

- (1926). Die sprachlaute experimentell-phonetische untersuchungen nebst einem anhang über instrumentalklänge. Berlin, DE: J. Springer.

TENNEY, J. (1988) A History of 'Consonance' and 'Dissonance'. White Plains, NY: Excelsior, 1988.

TERHARDT, E. (1974a) "Pitch, Consonance and Harmony" Journal of the Acoustical Society of America vol. 55 pp. 1061-1069

- (1974b) On the Perception of Periodic Sound Fluctuations (Roughness): Acustica, 30, 201-213

- (1977). The two-component theory of musical consonance. In:

Psychophysics and Physiology of Hearing (Evans, E.F., Wilson, J.P., eds.), Academic, London, 381-390

. (1979). Calculating virtual pitch. Hear. Res. 1, 155-182

- (1982). Die psychoakustischen Grundlagen der musikalischen Akkordgrundtöne und deren algorithmische Bestimmung. In: Tiefenstruktur der Musik (Dahlhaus, C., Krause, M., eds.), Tech. Univ. Berlin, 23-50

. (1984). The concept of musical consonance: A link between music and psychoacoustics. Music Percept. 1, 276-295

. (2000a, February 15). "Sensory consonance". Acesso em 18 de Agosto de 2011; http://www.mmk.ei.tum.de/persons/ter/top/senscons.html.

- (2000b, February 15). "Auditory Roughness". Acesso em 18 de Agosto de 2011; http://www.mmk.ei.tum.de/persons/ter/top/roughness.html

. (2000c, march 9). "Harmony". Acesso em 18 de Agosto de 2011; http://www.mmk.ei.tum.de/persons/ter/top/harmony.html

de 2010; . (2000d, February 13). "Afinitty of Tones". Acesso em 18 de Agosto . (2000e, February 22). "Virtual Pitch". Acesso em 18 de Agosto de 2010

2010 . (2000f, February 22). "Pitch Perception". Acesso em 18 de Agosto de

http://www.mmk.ei.tum.de/persons/ter/top/pitch.html

TERHARDT, E., STOLL, G., SEEWAN, M. (1982). Algorithm for extraction of pitch and pitch salience from complex tonal signals. J. Acoust. Soc. Am. 71, 679-688

TRAMO, M.J., CARIANI, P.A., DELGUTTE, B., \& BRAIDA, L.D. (2003). Neurobiology of harmony perception. In I. Peretz \& R. Zatorre (Eds.), The cognitive neuroscience of music, (127-151). New York: Oxford University Press.

TRAUNMÜLLER, H. (1990) “Analytical expressions for the tonotopic sensory scale". Journal of the Acoustical Society of America. N88: 97-100, 1990. 
TZANETAKIS, G. \& COOK, P. (2002) "Musical genre classifica- tion of audio signals," IEEE Transactions on Speech and Audio Processing, vol. 10, no. 5, pp. 293-302.

VAN IMMERSEEL, L. \& MARTENS, J. (1992) "Pitch and voiced/unvoiced determination with an auditory model," The Journal of the Acoustical Society of America, vol. 91, pp. 3511-3526

VASSILAKIS, P. N. (2001) "Perceptual and Physical Properties of Amplitude Fluctuation and their Musical Significance." Tese de Doutorado. UCLA.

WISHART, T. (1988) 'The Composition of Vox 5'. Computer Music Journal 12/4, 1988

ZWICKER, E. (1961) Subdivision of the audible frequency range into critical bands (Frequenzgruppen), Journal of the Acoustical Society of America. 33: 248, 1961

ZWICKER, E. e FASTL H. (1999) Psychoacoustics: Facts and Models, Berlin: Springer. 